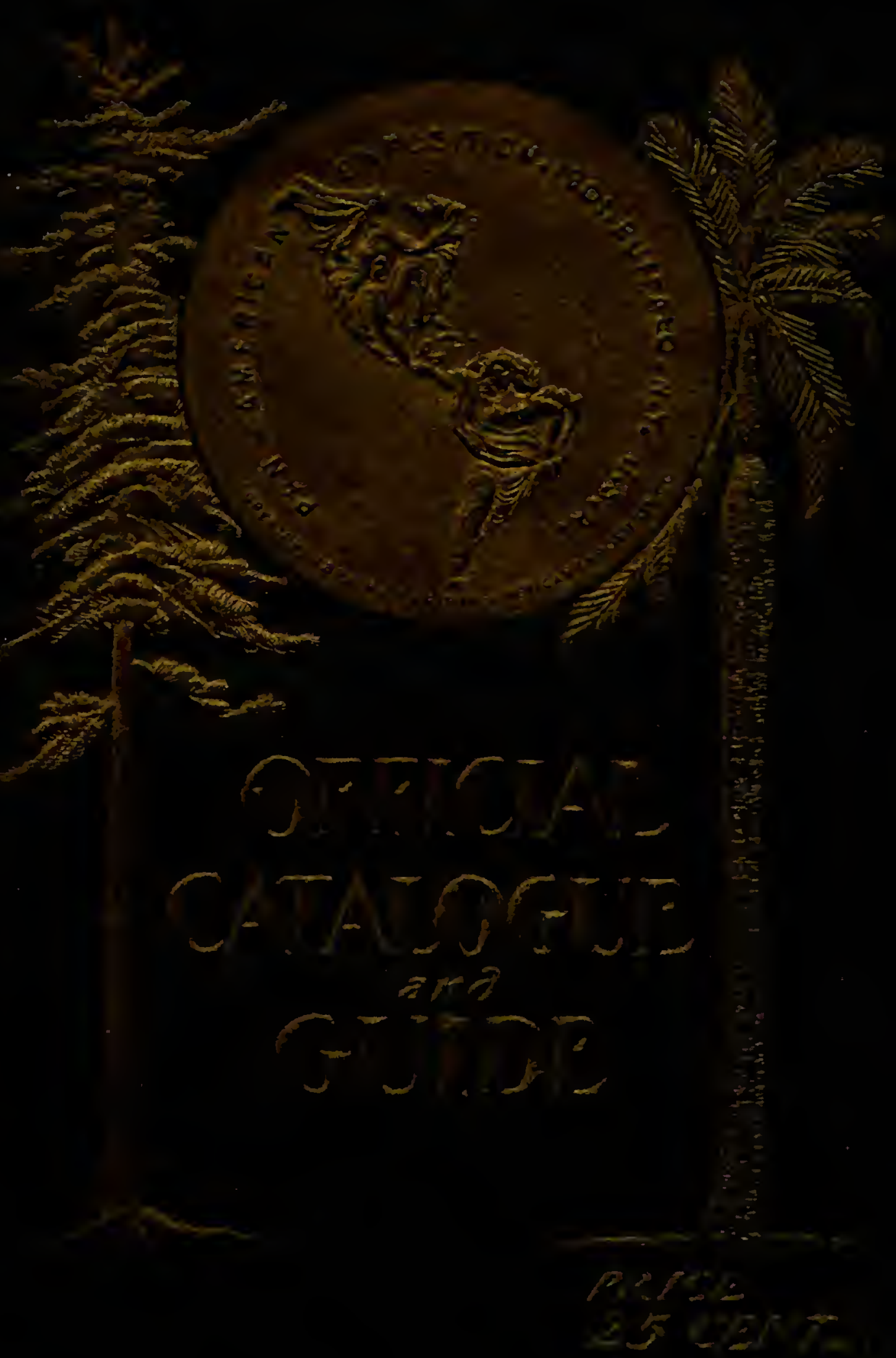




\title{
OFFICIAL CATALOGUE
}

485

AND

GUIDE BOOK

TO THE

Pan-Américan Exposition

With Maps of Exposition and Illustrations,

Buffalo, N. Y., U. S. A.

MAy ist to Nov. ist, igor.

\author{
*e \\ PUBLISHED BY \\ CHARLES AHRHART, \\ BUFFALO, N. Y.
}

Entered according to Act of Congress, in the year sgor, by Charles Alirhart, in the Office of the Librarian of Congress, at Washingtun. 
The Pan-American Offcial Catalogue and Gutde.

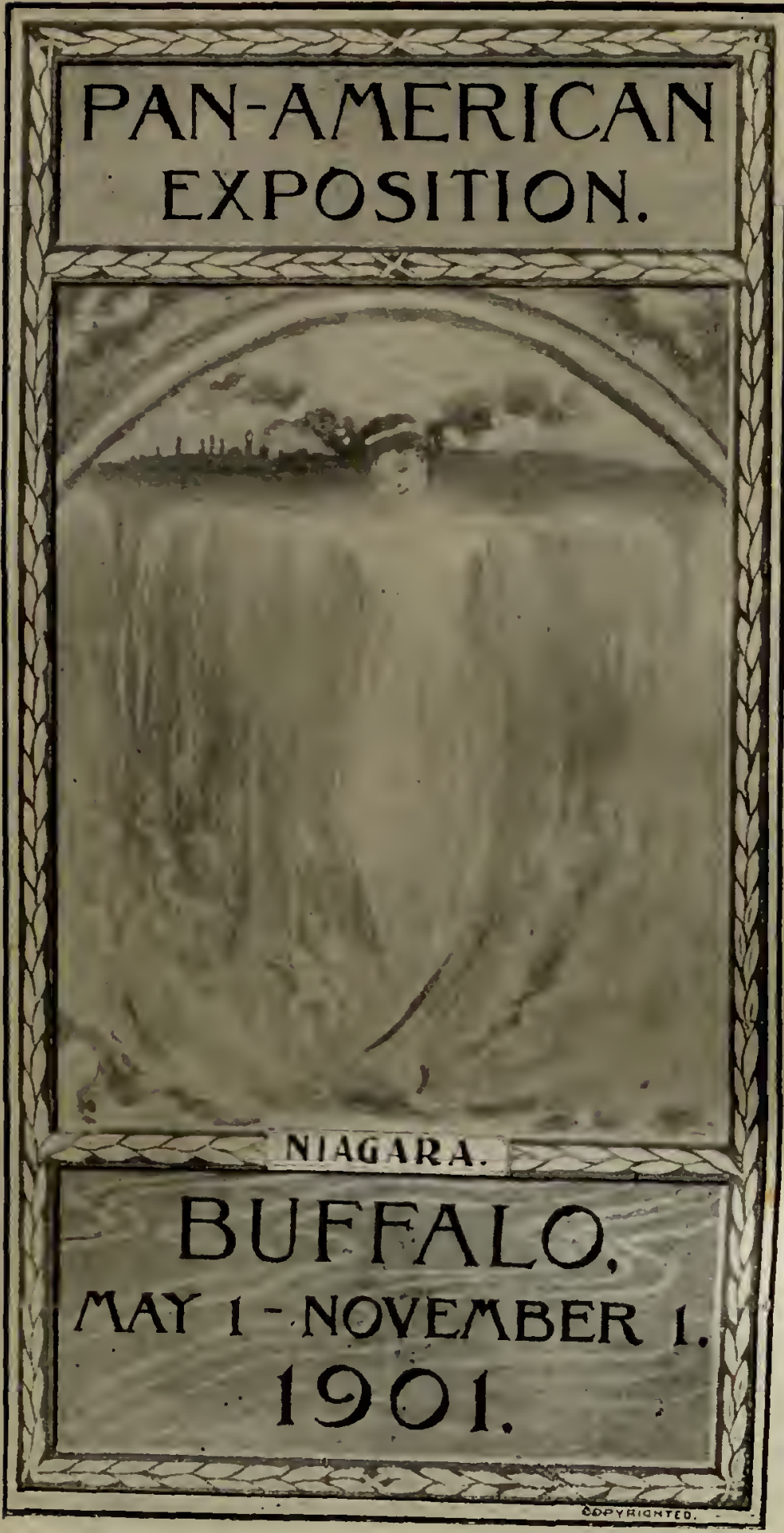


The Pan-American Official Catalogue and Gide.

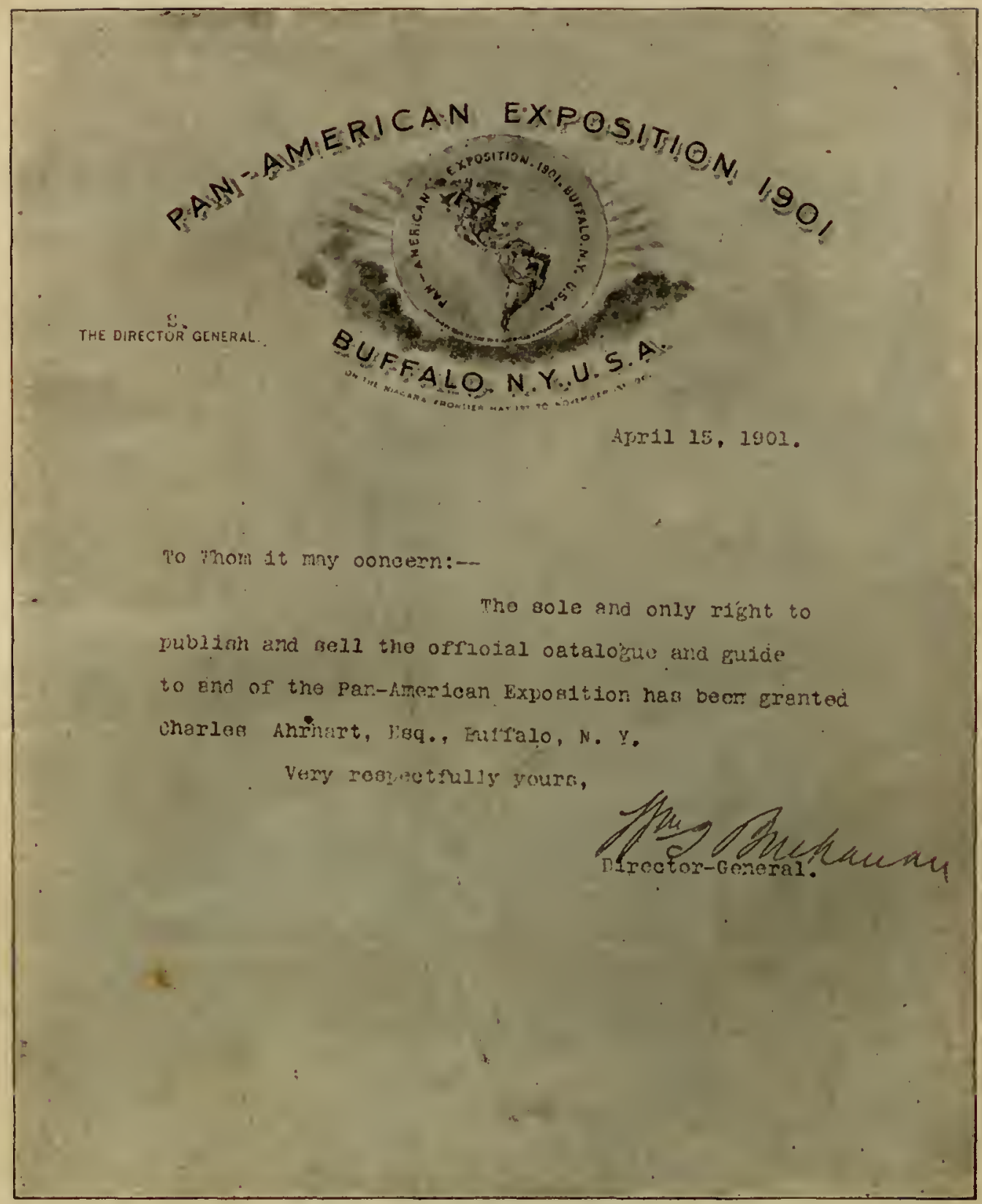


The Pan-Ameriean Offieial Catalogue and Guide.

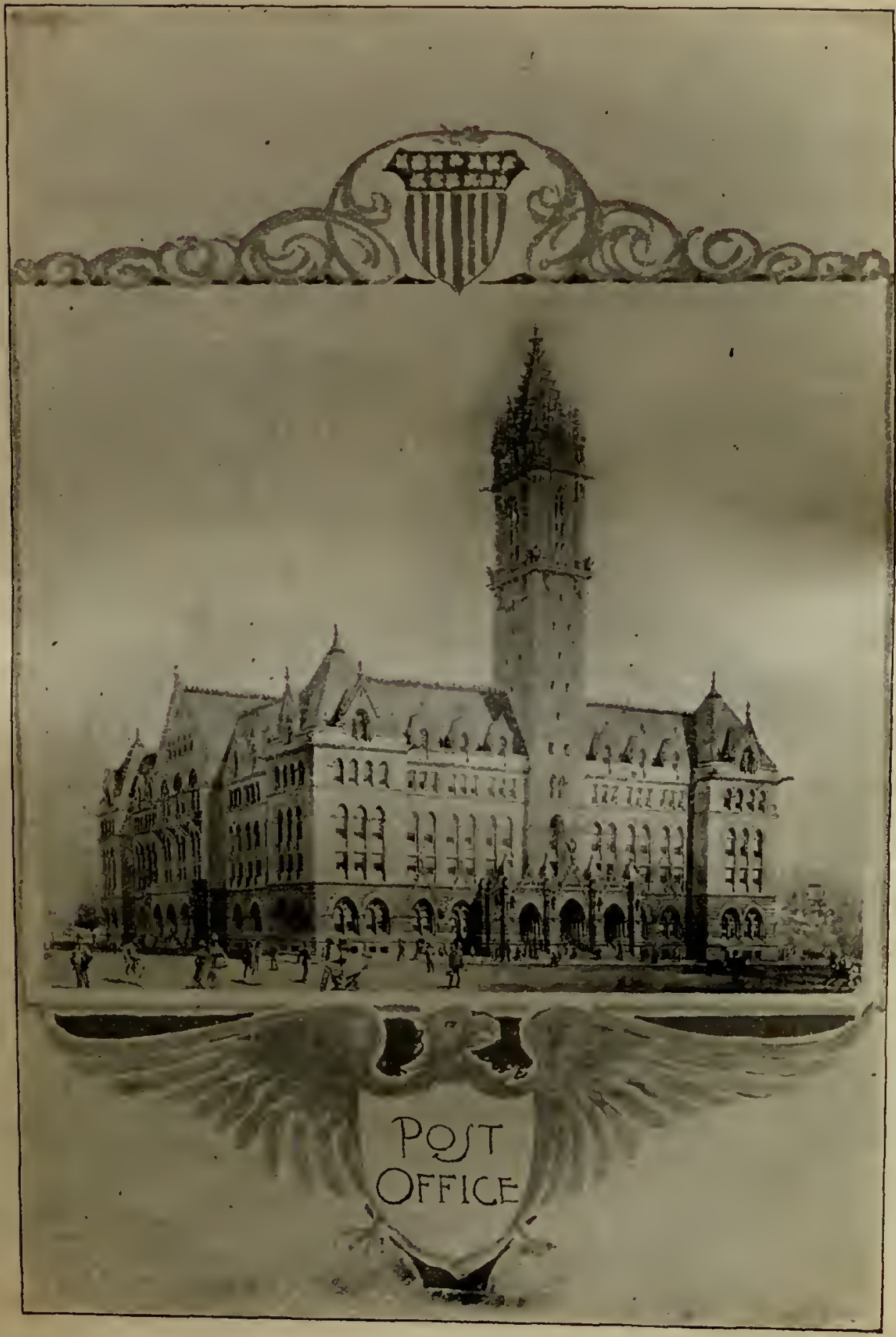


The Pan-American Official Catalogue and Guide.

\section{THE PAN-AMERICAN.}

Gearcely four years have elapsed since its conception, when it was $\circlearrowleft$ proposed to hold an Exposition which should be all. American in its scope.

Its sole olject, to promote commercial and social interests among the States and countries of the Western Hemisphere.

Its fundamental idea, essentially different from that of any other of the great fairs, in that it commemorates no historical event.

The citizens of Buffalo, in March, I899, raised by' popular subscription the sum of $\$ 1,750,000$, and because of this display of interest and the belief in their ability to finance and produce a successful Exposition, Congress became convinced that the work would be well done and designated Buffalo as the most desirable location, and accordingly assisted with an appropriation of $\$ 500,000$.

In 1899 the present business organization was effected, which chose for the site of the Exposition its splendid location, occupying as it does 350 acres of land and including a portion of Delaware Park, whose irrcgular lake, flowering shrubs and rare trees make it by far the most picturesque portion of Buffalo's famous park system.

Through the untiring efforts of the management, vast interest in Pan-Americanism has been created; all that is best and most interesting to display, has been secured from the commonzealth; and the result is an Exposition successful in every particular and worthy of its name. 


\section{OFFICERS, \\ DIRECTORS AND COMMITTEES OF THE \\ Pan $=$ American Exposition}

JOHN G. MILBURN, President.

EDWIN FILEING. Secretary.

GEORGE L. WILLIAMS, Treasurer.

\section{DIRECTORS.}

FRANK B. BAIRD.

GEORGE K. BIRGE,

HERBERT P. BISSELL,

GEORGE BLEISTEIN,

JOHN M. BRINKER,

CONRAD DIEHI,

W. CARYL ELY,

H. M. GERR $\Lambda$ NS,

CIARLES W. (GOODYEAR,

HARRY HAMLIN,

WILIIAM HENGERER,

CHARLES R. HUNTLEY,
JOHN HUGHES,

WM. H. HOTCHKISS,

J. T. JONES,

F. C. M. LAUTZ,

JOHN G. MITBURN,

E. G. S. MILLER,

H. J. PLERCL, JOHN N. SCITCHERD,

R. F. SCHELLING,

CARLETON SPRAGUE, THOMAS W. SYMONS, GEORGE URBAN, JR.,

GEORGE L. WILLIAMS.

\section{EXECUTIVE COMMITTEE.}

GEORGE K. BIRGE,

JOHN N. SCATCHERD, Chairman.
CONRAD DIEHL,

HARRY HAMLIN.

CHARLES R. HUNTLE):
J. T. JONES,

ROBERT F. SCIIELLING, CARLETON SPRAGUE,

H. J. PIERCE,

GEORGE W. AMES, Secretary to Chairman.

\section{BUILDINGS AND GROUNDS COMMITTEE.}

JOHN N. SCATCHERD, Chairman.

Buildings.

GEORGE K. BIRGE,

CARLETON SPRAGUE
Grounds.

HARRY HAMLIN, H. J. PIERCE, 


\section{BOARD OF ARCHITECTS.}

JOHN M. CARRERE, Chairman.

GEORGE F. SHEPLEY,

R. S. PEABODY,

WALTER COOK,
J. G. HOWARD.

GEORGE CARY.

E. B. GREEN,

AUGUST C. ESENWFIN.

C. Y. 'TURNER, Director' of Color.

KARL BIT'TER, Director of Sculpture.

\section{EXECUTIVE OFFICERS.}

WILLIAM I. BUCHANAN, Director-General.

GEORGE L. WILLIAMS, Treasurer.

JOHN B. WEBER, Commissioner General and Auditor.

INREDERIC W. TAYLOR, Director of Concessions.

JOHN BYRNE, Commander of Police.

ROSWELL PARK, Medical Director.

\section{DEPARTMEN'T OF WORKS.}

NEWCOMB CARLTON, Director of Works.

RLDOLF ULRICH, Isandscape Architect

J. H. MURPHY, Chief of Building Construction.

S. J. FIELDS, Chief Engineer.

HENRY RUSTIN, Chief M. and E. Bureau.

HARRY WEATHERWAX, Chief Draughtsman.

GEO. P. BRINTNALI, Superintendent of Plumbing.

R. H. CHERRY, Transportation Bureau.

\section{EXHIBIT DIVISIONS.}

GEORGE FRANCIS SEVER, Superintendent of Electrical Exhibits. WILLIAM A. COFWIN, Director of Fine Arts.

CHARLES C. CURRAN, Assistant Director.

THOMAS M. MOORE, Superintendent of Graphic Arts, Machinery, Transportation Exhibits and Agricultural Implements.

RICHMOND C. HILI, Assistant Superintendent of Graphic Arts. EDWARD N. SQUIRES, Assistant Superintendent of Machinery.

I.IEUT. GODFREY L. CARDEN, in charge of Ordnance Division. SELIM H. PEABODY, Superintendent of Liberal Arts.

JACOB S. OTTO, Assistant Superintendent of Sanitary Exhibits. A. L. BENEDICT, Superintendent of Ethnology and Archaeology. FRANK A. CONVERSE, Superintendent of Live Stock and of Dairy Products and Agricultural Products. 
The Pan-American Official Catalogue and Guide.

FREDERIC W. TAYLOR, Superintendent of Horticulture, Forestry. and Food and Their Accessories.

WILLIAM SCOTT, Assistant Superintendent of Floriculture.

H. E. VAN DEMAN, Judge, Division of Horticulture.

F. De P. TOWNSEND, Assistant Superintendent of Forestry.

G. EDWARD FULLER, Assistant Superintendent of Food Products. DAVID T. DAY, Superintendent of Mines and Metallurgy. ALGAR M. WHEELER, Superintendent of Manufactures.

\section{BUREAU OF PUBLICITY.}

MARK BENNITT, Superintendent of Press Department. F. R. ROSSEEL, Superintendent of Advertising Department. J. F. NOEL, Chief of Latin-American Press Section. F. F. HELMER, Designer.

EDWARD E. PIDGEON, New York City Representative. VESTA E. SEVERINGHAUS, Chicago Representative.

\section{BUREAU OF TRANSPORTATION.}

JAMES V. MAHONEY, Superintendent of Passenger Department. BRUCE ELLIS, Superintendent of Freight Department.

\section{BUREAU OF LAW AND INSURANCE.}

OSCAR T. TAYLOR, Secretary.

BUREAU OF PRINTING AND SUPPLIES.

FRANCIS ALMY, Purchasing Agent.

\section{BUREAU OF INFORMATION.}

W. J. THAYER, Superintendent.

\section{MILITARY BUREAU.}

CHARLES J. WOLF, Chief.

\section{SPORTS AND ATHLETICS.}

JESSE C. DANN, Chairman.

BUREAU OF ADMISSIONS AND COLLECTIONS.

W. E. CASI, Superintendent. 
The Pan-American Official Catalogue and Guide.

\section{STANDING COMMITTEES OF THE EXPOSITION.}

STATE AND FOREIGN RELATIONS-J. N. Adam, Chairman; D. S. Alexander, Charles F. Bishop, J. J. H. Brown, Jos. E. Gavin, Alfred Haines, Arthur C. Hastings, R. R. Hefford, Lucien Howe, William L. Marcy, J. W. Robinson, Laurence D. Rumsey, William H. Ryan, T. Guilford Smith. Nicholas Veloz-Goiticoa, Secretary.

FINANCE-Franklin D. Jocke, Acting Chairman; J. J. Albright, Stephen M. Clement, Eugene A. Geolger, Frank H. Goodyear, William Hamlin, Elliott C. McDougal, Pascal P. Pratt, Charles A. Sweet, Geolge L. Williams.

PUBLICITY-George Bleistein, Chairmar; E. H. Butler, William C. Colnwell, W. Caryl Ely, F. C. B. Held, Charles F. Kingsley, Norman E. Mack, Darwin D. Martin, Geo. E. Matthews, E. G. S. Miller, Ray V. Pierce, Thomas T. Ramsdell, Ottomar Reinecke, George T. Smith, James Gerard Snith, Jacob Stern.

EXHIBITS-Frank B. Baird, Chairman; Michael Danaly, Charles Groben, P. H. Griffin, George B. Hayes, Clarence M. Howard, C. H. Keep, Geo. E. Laverack, O. P. Letchworth, M. B. Patch. A. E. Perren, E. R. Rice, James M. Rozan, R. K. Smither, C. E. Walbridge.

CONCESSIONS-H. J. PIERCE, Chairman; Frank B. Baird, Arthur D. Bissell, Edmund Hayes, Charles R. Huntley, George P. Sawyer, Pendennis White.

TRANSPORTATION-W. Caryl Ely, Chairman; R. Bell, J. P. Bradfield, C. A. Brumn, P. C. Doyle, W. C. Farrington, H. S. Fisher, F. P. Fox, D. Lundergan, J. D. McDonald, C. E. Markham, Frank J. Moore, J. J. Mossman, Tracy W. Niles, Harry Parry, H. J. Pierce, W. H. Underwood.

FINE ARTS-T. Guilford Smith, Chairman; J. J. Albright, Willis O. Chapin, William C. Cornwell, William A. King, Ralph H. Plumb, George P. Sawyer, L. G. Sellstert, Carleton Sprague.

MUSIC-F. C. M. Lautz, Chairman; John H. Cowing, Walter J. Dunham, Simon Fleischmann, H. M. Gerrans, Raphael Herman, R. H. Heussler, Geo. A. Lewis, Hobart Weed. 
The Pan-American Official Catalogue and Guide.

ENTERTAINMENT-John G. Millurn, President of the Exposition, Chairman; R. B. Adam, Frank L. Bapst, Henry W. Box, H. W: Brendel, John Mr. Brinker, George H. Bush, John Coleman, E. 't. Evans, Theodore Fassett, C. W. Hammond, C. Hallani Keep, D. H. McMillan, James Mooney, Roswell Park, Robert W. Pomeroy, Mathias Rohr, Robert K. Root, Augustus F. Scheu, Henry H. Sey. mour, James R. Smith, Henry Ware Sprague, Thomas Stoddart, George Urban, Jr., William G. Vought, Henry M. Watson.

LAW AND INSURANCE-Herhert P. Bissell, Chairman; James A. Roberts, Robert F. Schelling. Oscar T. Taylor, Secretary.

PRINTING AND SUPPLIES-William H. Hotchkiss, Chairman; H. V. Bisgood, H. M. Gerrans, William Hengerer, F. C. M. Lautz. Francis Almy, Purchasing Agent.

SPORTS AND ATHLETICS-Jesse C. Dann, Chairman; Charles Cary, Irving R. Johnson, J. McC. Mitchell, John B. Olmsted, Charles M. Ransom, Seward A. Simons, Wm. B. Wright, Jr., C. R. Wyckoff.

BOARD OF WOMEN MANAGERS-Mrs. William Hamlin, President; Mrs. J. J. Albright, Mrs. Tracy C. Becker, Miss Ida C. Bender, Mrs. Charies Cary, Miss Annie Damer, Mrz. Joseph Desbecker, Mrs. Jos. E. Gavin, Mrs. David Gray, Mrs. P. H. Griffin, Mrs. A. G. Hanenstein, Mrs. John M. Horton, Mrs. Charles F. Kingsley, Mrs. Norman E. Mack, Mrs. Geo. E. Matthews, Mrs. Adelbert Moot, Mrs. Herman Mynter, Mrs. Elizabeth B. McGowan, Mrs. W. A. Rogers, Mrs. Robt. K. Root, Mrs. J. F. Schoellkopf, Jr., Miss Frances G. Stanton, Mrs. George W. Townsend, Mrs. Herman Waterman, Mrs. Lester Whee!er. Miss Marian DeForest, Secretary.

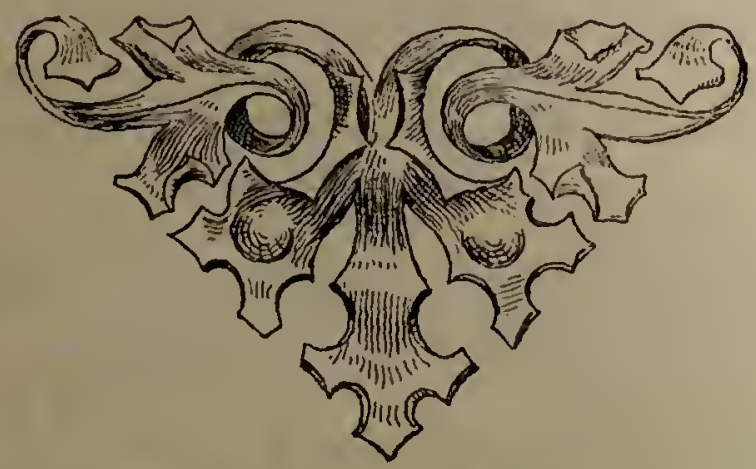




\section{The Exposition.}

The problem of starting is the only one with which those who contemplate visiting the Exposition will meet, and that is so easy that it is answered by the single word "Start." Situated as Buffalo is, the center from which radiate trunk lines to every point of the compass, it may safely be said to enjoy railway facilities possessed by no other city in the world; in the heart of the commercial continent, accessible by rail from all parts of the country, and in dilect communication with the system of Great lakes. Attrastive in topograply and ornate in every description of architecture, the Queen City of the Iakes invites the world to come into her midst and be her guest from May first to November first, 1901.

The Rainbow City, thirty minutes' ride from the heart of Buffalo, under splendid domes, attractive minarets, towers and pavilions aglow with numberless pleasing hues and tints, and within the classic outlines of its buildings, visitors will be regaled with views showing the progress of the few years past, ornamented and enlarged by attractive exhibits from all parts of the Western Hemisphere. Second in size only to the World's Fair and far more attractive and unique in many particulars beyond that display in 1893 , and thoroughly original in its most distinctive features, the Pan-American Exposition opens its gates feeling confident that no visitor will be disappointed.

\section{GENERAL PLAN OF GROUNDS.}

The general plan of the Exposition grounds can be compared to that of an inverted "T" with the cross arm as the Esplanade extending east and west, and the vertical stem cxtending nortli, terminating in the Propylaea or entrance to the lailway station. The Court of Fountains is in the center of the vertical stem and starting from its four corners is the beginning of the main group of large buildings. From the railway station and passing through the Plaza, the visitors enter the court; to the westward are the Electricity, the Machinery and Transportation buildings, separated by the Sunken Gardens which are filled with the choicest of flowers and cooling fountains, the water taking the form of beautiful flowers, etc. To the eastward are the buildings for Agriculture, and Manufactures and Liberal Arts, also separated by Sunken Gardens. Standing in a broad basin to the northward of the Court is: the Electric Tower. rising to a height of 391 feet, adorned with many costly groups of sculpture unon its salient points, and from a niche in 
The Pan-American Official Catalogue and Guide.

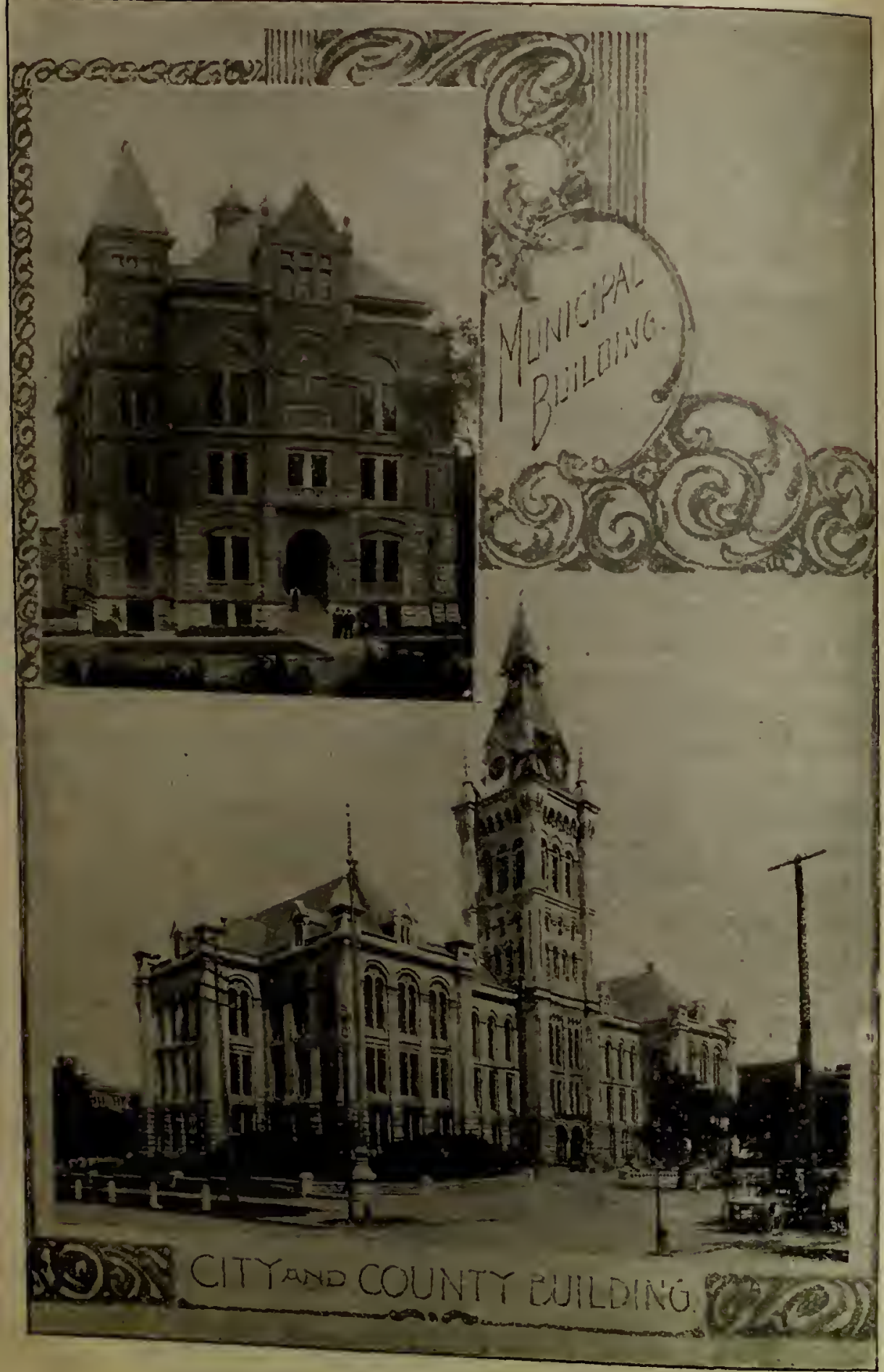


The Pan-American Official Catalogue and Guide.

Its southern face gushes a cascade 70 feet high and 30 feet wide. Connecting with this basin, a canal bordered by beautiful trees and crossed by arched bridges, runs westward to the north of the Electricity building and eastward to the north of the Agriculture building and then turns and flows southward terminating in the Mirror Lake; filled with grottoes and effects of marvelous beauty and interest. Facing the Esplanade on the north is the Cascade Fountain, and at either end are the Esplanade fountains, surrounded as they are with statuary of every description. The Esplanade is designed so as to be capable of holding 250,000 people, and from its southern end entrance is effecter from the Fore Coüt over the Triumphal Bridge, surmounted on its four coruers by four massive towers two hundred feet high. The Esplanade is provided with highly ornamented band stands, and outdoor concerts will be given by the finest bands of the country.

\section{EXPOSITION COLOR SCHEME.}

In all previous expositions, the main feature has been the architectural work and not color. But this one represents both, and is after the plan designed and directed by $C$. X. Turner, representing the fierce struggle of "man to overcome the elements."

As one enters the grounds, on the left will be seen buildings which represent "elements," and on the right those representing man and his affairs, or that which man has gained after long years of struggling to overcome the elements.

The struggles are represented by heavy deep coloring of red, blue, green and gold, graduating gently but firmly in tints, until the electric tower is reached, where it again commences in a deep green as near the color of Lake Erie as it was possible to get it. The tower itself is a cream white with sculpture work on the four corners, and is tinted with blue, green and go!d, getting fainter until the top is reached, terminating in the figure representing all that man has accomplished over the elements.

\section{ILLUMINATION.}

The illumination is the most brilliant and elaborate ever contemplated. An Electric Tower soaring to a lofty height, and surmounted by a splendid statue of the Goddess of Light, is the centerpiece of this great dominating teature of the Exposition. It is studded with incandescent lamps and powerful searchlights, one of which, at a great height, sends its gleams for many miles around, embracing in its grand circle the Falls of Niagara and the Canadian Frontier. Every great building is outlined with a myriad of lights, and the staff glows with effulgent splendor. The Court of Fountains is urilianily and fantas- 
The Pan-American Oflcial Catalogue and Guide.

tically illuminated. Colored lights from concealed electric bulbs are absorbed by the flowers in the gardens of the courts. A cascade gushes from a niche in the tower, from which scores of searchlights play their iridescent colors upon the scene.

\section{ARCHITECTURAL FEATURES.}

The style of architecture, a free treatment of the Spanish Renals sance, is a compliment to the Latin-American countries, who are prom. inent exhibitors.

Column and entablature have been used for decorative, rather than for architectural effects, and the exterior of every building presents great richness of design, by the generous use of colonnades, balconies, loggias, towers and minarets, commanding broad views of the grounds.

Grand original sculptured groups, designed by leading American artists, guard entrances and bridges, lacking only life to complete the ideality of their purpose.

Instead of glaring white, there is color everywhere, and color used on color to gain the desired effect.

Beautiful decorations in color are so profuse that it makes one shudder to reflect that all this was improvised for the fleeting purpose of a season's passing show.

The largest architectural synthesis of the Exposition surrounds the Court of Fountains. Here are grouped on the east and west the Manufactures and Liberal Arts, and Machinery and Transportation build. ings, with the Agriculture and Electricity buildings opposite, while between the Court and the Plaza rises the Electric Tower to a height of 391 feet, upon which are displayed electrical phenomena hitherto un. attempted.

At the base of the tower two colonnades, 75 feet high, sweep to the southward and form a semi-circular space opening toward the Court of Fountains, and on the top of its domed cupola a superb figure, the Goddess of Light, is poised, overlooking and dominating the entire Exposition.

But even here the art spirit dominates, and the entire exterior of the tower is richly ornamented with plastic design and sculpture, and the ordinary visitor will certainly find himself more inclined to study the wonderful freedom and beauty of the decorations than to go seriously into the evidence they give of the progress of electrical science.

In the center of this Court lies the Aquatic Basin, covering two acres. This has been treated with a view to bringing out special de signs in jets of water, which take the form of magnificent sculptures in large numbers. 
The Pan-American Official Catalogue and Guide.

\section{EXPOSITION ENTRANCES.}

The grounds are provided with sevell entrance gates. The one at the northern extremity of the grounds is that provided to receive the numbers who will arrive by steam railroad, all the different lines coming into one central station. This will also be the gate for the Niagara Falls, Lockpont and Hertel avenue trolleys.

The Elmwood gate and Amherst gate $a_{4} e$ on the western side of the grounds and are accessible to the many electric car lines which run to the center of the city and connect by transfer to all the other lines of the system. The entrance is reached by the following car lines: Michigan, Main, Elmwood, Niagara, Baynes and Hoyt, and West avenue and Grant street.

The Meadow gate, Water gate and the Lincoln Parkway gate, are on the southern side of the Exposition grounds, and are the gates through which those will come who drive or walk to the grounds from the city. The Water gate and Lincoln Parkway gate are almost directly on the Forest avenue car line.

The East-Amherst gate, located on the eastern side of the grounds, will be the one most easily accessible to those living in the northeastern section of the city and is reached by the Main and the Jefferson street lines.

\section{THE TRIUMPHAL BRIDGE.}

One of the most majestic and distinctive decorative features of the Exposition is the Triumphal Bridge. This spans the Grand Canal between the Mirror Lakes and leads the visitor from the Fore Court to the Esplanade. The composition is intended to express the pride of the people of the North American Union in their country. In this splendid gateway are four gigantic piers, upon which mounted standard bearers hold aloft the national emblem, and about the bases are trophies of peace and war, and numerous other pieces of statuary, each expressing some phase of national greatness. The architects of the bridge are Carrère \& Hastings of New York.

\section{THE GRAND CANAL.}

The Grand Canal, over a mile in length, extends around the central group of large buildings. Winding lagoons connecting with the canal branch off in all directions. The Mirror Lakes in the southern portion of the canal. form a picturesque feature. The outer bank of the canal and the banks of the lagoons are sodded and set with trees and flowers, producing vistas of unusual interest and beauty. Electric launches, 
The Pan-American Official Catalogue and Guide.

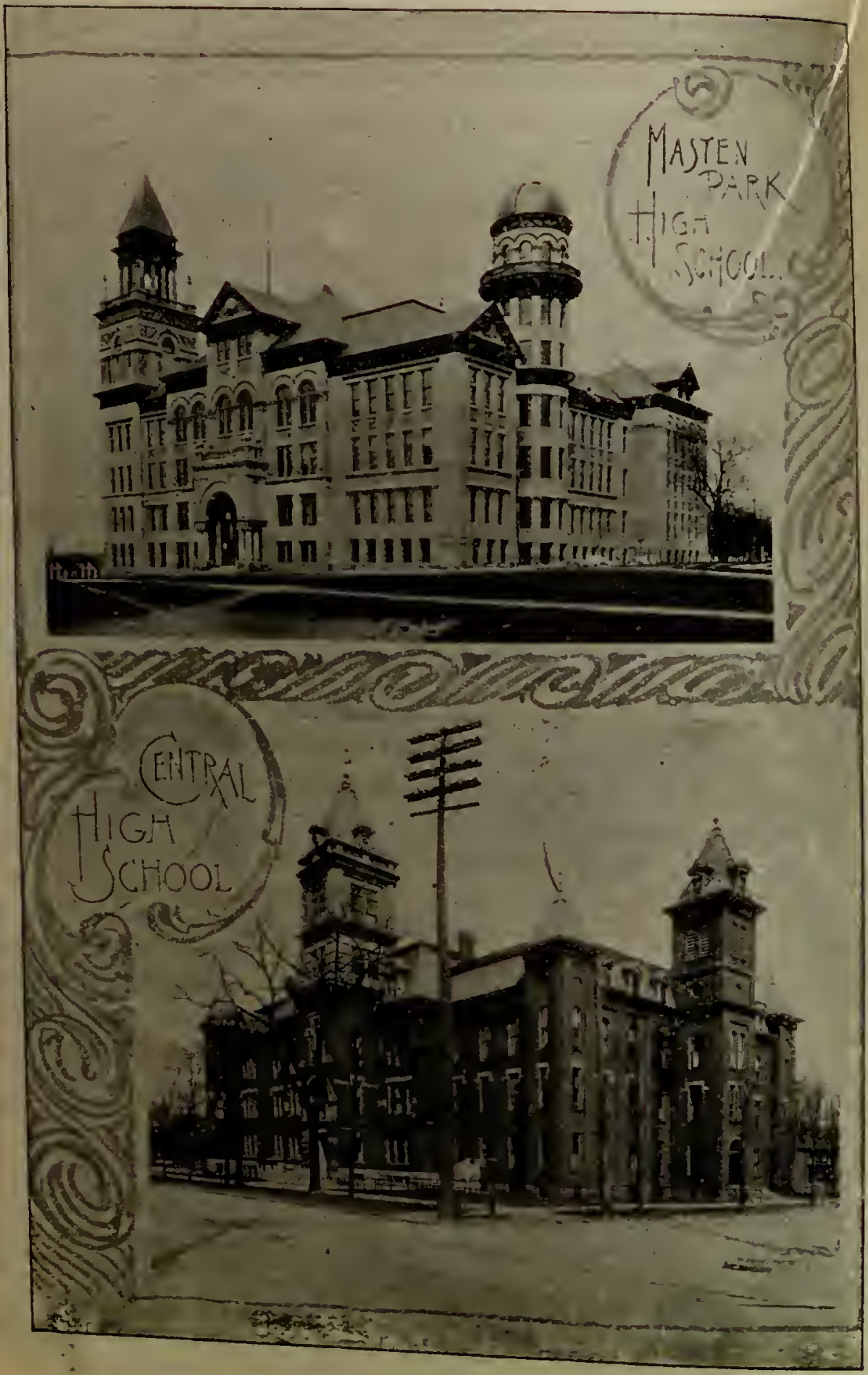


gondolas and other small craft ply from place to place. The ride is a refreshing one, with charming views at every turn. Romantic bridges span the waterway at convenient points, and statuary placed everywhere adds to the picturesque effect.

\section{THE PLAZA.}

The Plaza is situated at the Northern end of the Exposition grounds and is bounded by three buildings, forming a square 350 feet by 500 feet, its name being suggested because of the very free version of Spanish architecture adopted in the surrounding buildings.

North of the Plaza is the railway station, which is masked by the Proplyaea, a colonnade flanked at either end by two colossal entrance and exit arches. West of the Plaza is a restaurant 350 feet long, two stories high and through the lower arches visitors may pass to the Midway. East of the Plaza is the entrance to the Stadium, resembling that erected at Athens some years ago. The buildings surrounding the Plaza are from the designs of Babb, Cook \& Willard of New York.

\section{THE ELECTRIC TOWER.}

Soaring to a height of 391 feet stands the Electric Tower, the crowning centerpiece of the Exposition. The main body of the tower is 80 feet square and 200 feet high. The crown being in three parts, of diminishing proportions. The first of these is an arcaded loggia richly ornamented in all details. Pavilionettes adorn each of the four corners and terminate in cupolas. Above the loggia is a high circular colonnade entirely open, so as to allow the effect of the sky to be seen between the columns. A spiral stairway in the center leads up to a domed cupola on which is poised a superb figure, the Goddess of Light, overlooking and dominating the entire Exposition. At the base of the tower, on the east and west sides, two colonnades, 75 feet in height, sweep to the southward and form a large semi-circular space opening toward the Court of Fountains. The Tower is entered by way of an ornamental bridge from the Plaza on the north side. Elevators carry the visitors to the many floors. At a height of 75 feet is a large restaurant, from which one may stroll upon the roof gardens above the colonnades. From the various floors, the visitors may obtain interesting views of the Grounds, the City, Lake Erie and Niagara river.

The color scheme is a cream white, beautifully trimmed in blue and gold, and the entire exterior is richly ornamented with plastic designs and sculpture. The panels on the four walls are of open work, so that the effect at night when the interior is lighted is exceptionally brilliant and grand. The Tower stands in a basin and from a niche in its face gushes a cascade 30 feet wide and 70 feet high.

The entire framework of the tower is of steel and was the design of Arrhitect John Galen Howard of New York. 
The Pan American Official Catalogue and Guide.

\section{U. S. GOVERNTENT BULLDINGS.}

The buildings erected by the U. S. Government are located at te extreme end of the Esplanade, facing the East fountain. They were designed under the direction of the Supervising Arehitect of the Treas. ury Department, Mr. J. K. Taylor, and consist of three structures connecied by curved arcades, the middle one being crowned by a dome 250 feet above the main floor, on which is an imposing figure of Victory, 20 feet high. The cost to the Government for the three buildings and the exhibits contained in them was $\$ 500,000$. The Departmental exhibits are the largest and most complete ever made at any exposition and include the War and Navy, Postoffice, Agriculture, Treasury and the different bureaus of the State Department. In the central building the Postosice Department occupies a space to the left of the entrance. The' methods of mail trancmission are fully illustrated and a postoffice equipped wilh all the latest devices used in the larger offices of the United States is the feature of the exhibit.

The exhibit of the National Museum, under the auspices of the Smithsonian Institute, will be found of absorbing interest, displaying as it does the resources of the Americas, the West Indies, and the new possessions of the United States.

The Fisheries exhibit, which is located in the building occupying the most southern position of the three, is beyond question the most complete of its kind ever attempted, and illustrates the various methods of fish propagation, and the boats and apparatus used by fishermen in the many lines of this most important industry.

\section{EIECTRICITY BUILDING.}

Northwest of the Court of Fountains, with its eastern end facing the Electric Tower, is the Electricity building. The area covered by the building is seventy-five thousand square feet, the structure being five hundred feet long from east to west, and one hundred and fifty fect wide.

In front of the building, flanking both sides of the main entrance, is an open portico fifteen feet wide, extending along the entire building, to which entrances open on all sides. It was designed by Architects Green \& Wicks of Buffalo, N. Y., who also designed the Machinery and Transportation building, next south. The windows are grilled in somewhat the same manner, while the color scheme is light yellows and reds. The main floor covers an area of twenty-five thousand square feet of Falls Transformer Plant, with a capacity of five thousand horse-power, the purpose of which is to transform the power delivered from Niagara Falls to a lower voltage so that it can be used for distribution about the 
grcands, to operate lights and other electrical appliances. The few years which have passed since the Chicago exposition have witnessed a phenomenal adrance in electric science, and today it is no discredit to former expositions to saly the Electricity building of the Pan-American surpasses anything thus far attempted in this direction. The development of electric power is illustrated in a very comprehensive manner; working models of many of the great plants are on exhibition, and those who desire to see the plants themselves will have only to go a distance of twenty miles from the grounds - a ricle of about thirty minutes-in order to do so.

The names and locations of the various exhibits will be found on another page of this book.

The following classification of exhibits into fourteen groups has bcen adopted:

Group 1-Apparatus illustrating the phenomena and laws of electricity and magnetism.

Group 2-Apparatus for electrical measurements.

Group 3-Electric batteries, primary and secondary.

Group 4-Machines and appliances for producing electrical currents by mechanical power-dynamo-electric machinery.

Group 5-Application of electric motors; elevators; power and railways.

Group 6-Transmission and conversion of electric power, including recent types of large transformers constructed for the purpose of transforming high potentials, with working models of various transmission lines.

Group 7-Systems of lighting by electricity-arc and incandescent.

Group 8-Heating by electricity, showing the latest methods and apparatus for heating cars, and the maintenance of high temperatures uader particular conditions; the heating of flat irons, cooking and baking by electricity; electric forging, welding, stamping, tempering and brazing, showing by the most recent devices the wide application of electricity to the working of metals.

Group 9-Electro-metallurgy and electro-chemistry.

Group 10-Electric telegraph, electric signals, wireless telegraphy.

Group 11-The telephone and its appliances.

Group 12-Elcctricity in surgery, dentistry and therapeutics. The results of $\mathrm{X}$-ray work are included in this section.

Group 13-History and statistics, progress and development in electrical science and construction from its inception, as illustrated by mod. els, drawings, literature or otherwise.

Group 14-Electricity in submarine and torpedo work, as used in engineering and warfare.

The cost of the building, without ornamentation, was $\$ 130,000$. 
The Pan-American Official Catalogue and Guide.

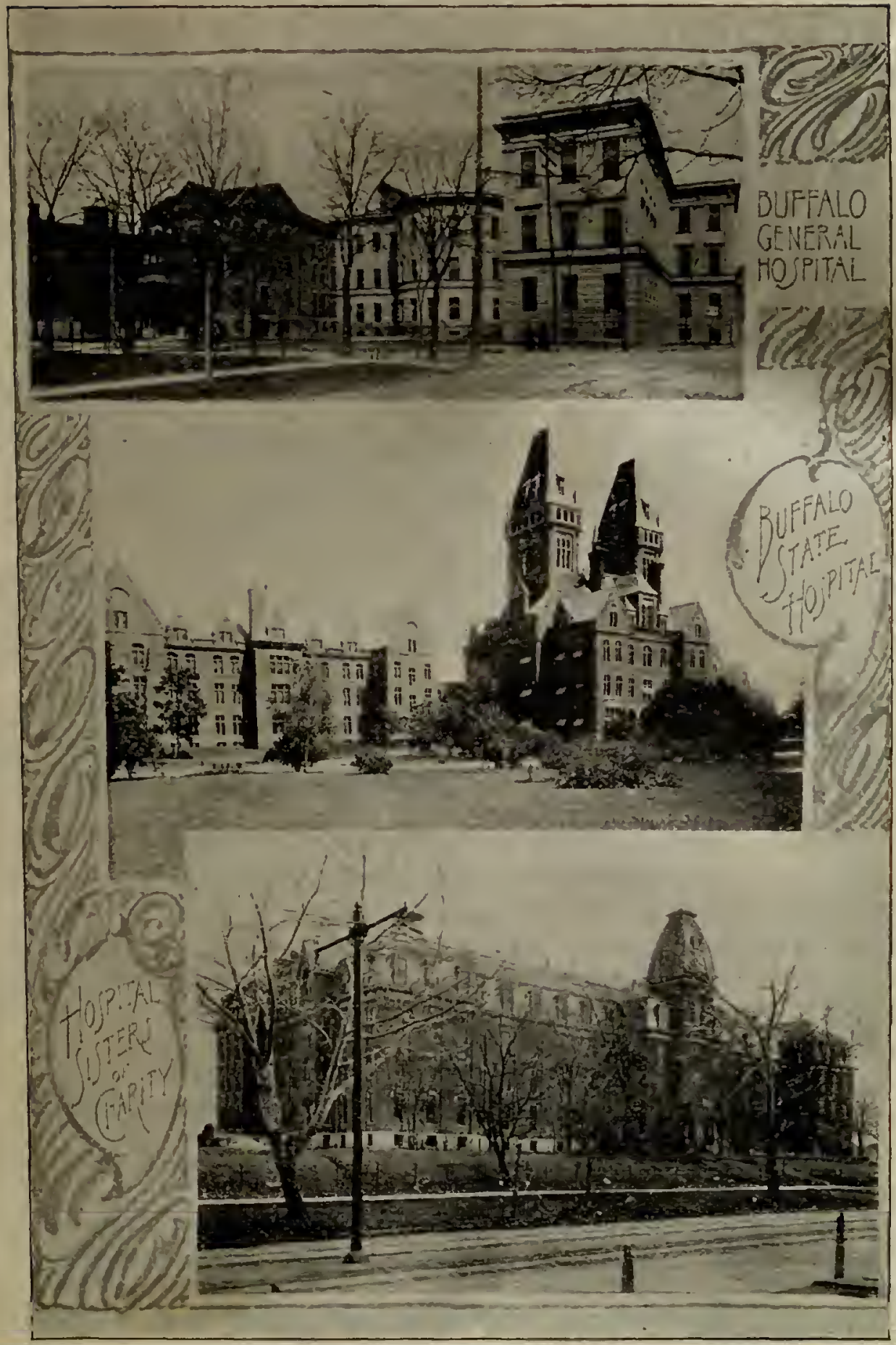


The Pan-American Official Catalogue and Guide.

\section{MACHINERY AND TRANSPORTATION BUILDING.}

Southwest of the Court of Fountains and separated from the Manufactures and Liberal Arts building by the Cascades is the Machinery and Transportation building. It occupies a space $500 \times 350$ feet or about four acres. The building is in the form of a hollow square, with arcades on all sides and an interior court $100 \times 200$, where the pumping station for the Exposition is located. It was designed by Architects Green \& Wicks of Buffalo, N. Y. The roof is of red tile and its cement walls are tinted with a color scheme of light reds and yellows. The windows are grilled with iron screens designed after the Spanish "rejas" of the sixteenth century. As an architectural work the building is a masterpiece, in the style of the Spanish Renaissance. The main entrances in the north and south facades are flanked on either side by tall towers having open lanterns and an intricate detail of plastic ornamentatio?. The entrances are all rich in their decorative work and the walls are broken with arcaded windows. Each facade is thus enriched with im. portant architectural features and at the four corners are open pavilions from which charming views of the grounds may be obtained. The Machinery exhibits include the most modern agricultural machinery and appliances, and the wonderful display of modern machinery of American invention illustrates the progress that has been made within the last few years. The Transportation exhibit is no less interesting, and includes all of the very latest specimens of road vehicles, locomotives, cars and railroad appliances.

The cost of the building, exclusive of ornamentation, was about $\$ 265,000$.

For list and location of exhibits, see the floor plan.

\section{MANUFACTURES AND LIBERAL ARTS BUILDING.}

Southeast of the Court of Fountains and separated from the Machinery and Transportation building by the Cascades, is the Manufactures and Liberal Arts building, a handsome structure entirely surrounded with a portico about fifteen feet wide, with openings through semi-circular arches, supported by square columns. On the four ends of the building and in the center of the front, are towers crowned by domes, and through which are the entrances to the building. Over the main entrance of the building on the south is a high dome, flanked by four square, open towers. Broad steps between large groups of statuary lead up to the entrance, which consists of a high arch with two tall columns on either side. Above the arch elaborate relief work enriches the gable. Statues symbolizing the various arts and industries are 
The Pan-American Official Catalogue and Guide.

placed in the niches at the angles of the several open towers around the dome. The towers may be reached by open spiral staircases, 17 feet in diameter. The interior of the dome, 70 feet across, is encircled by ga: leries from which one may have a good view of the crowds below. The several entrances and all the exterior work upon the building are of? highly ornamental character, much attention having been given both the detail and ensemble. The building is lighted from the windors o the loggias and around the inner court, and from skyliglits. Its dimen sions are $500 \times 350$, having an exhibit space of about four acres. 1 : was designed by Architects Shepley, Routan \& Coolridge of Boston, Mass. The color scheme used on the building is of light browns and reds.

Similar to the Machinery and Transportation building, it has a cen. tral court 200 feet by 100 feet, which is uzed entirely for jewelry and cult glass exhibits. Here the visitor will find gathered together in profusion the very latest, productions of the mills and factories of the United States and other countries of the Western Hemisphere, and it may safely be said to be the greatest variety of manufactured products ever brought together. Foods and their accessories, a division having a place in the $\mathrm{N}$. W. end, show the possibilities for food production in Pan-America.

The Department of Liberal Arts, in the N. E. end of the building, includes education, engineering, public works, architecture, literature and kindred subjects.

The cost of the building was $\$ 255,000$.

For list of exhibits, etc., see the floor plans on another page of this book.

\section{AGRICULTURE BUILDING.}

The Agriculture building occupies the space northeast of the Court of Fountains, with its western end facing the Electric Tower. It is fire hundred feet long and one hundred and fifty feet wide, with its longest dimension extending east and west. The architects were Shepley, Rou $\tan \&$ Coolridge of Boston, Mass. Along the north and south sides of the building extends an open portico flanked by semi-circular' arches, supported on cylindrical columns. The color scheme is in light yellows and reds. In this building will be found agricultural exhibits of a most interesting character, and articles pertaining to the farm, showing many of the wonderful possibilities in farm work. Exhibits from all the South and Central American countries are located on the main floor, and on the north side a gallery is provided for smaller exhibits.

This building is the magnet which attracts progressive farmers, where they can learn how to lighten their labors and improve tho 
The Pan-American Official Cataiogue and Guide.

products of their fields. The exhibits embrace all phases of agricultural work, showing the advantages of different processes and methods of work, and the farm products under all sorts of conditions. Ample provisions have been made to give this important industry the attention it deserves. The exhibits are divided into 13 classes, arranged in three groups.

The first group of six classes is composed as follows: Agricultural systems, management and processes; agricultural statistics; cereals; tuber's and loot crops; by-products user for food; agricultural products not otherwise classified.

The second group of five classes is as follows: Grasses and forage; fibres of vegetable origin and the processes; fibres of animal origin and the processes; non-erlible products of animal origin; and natural fertilizers, crude and compounded.

The third group includes dairy management and appiances, and dairy products.

The cost of this bnilding, without ornamentation, was about $\$ 90,000$.

List of exhibits appears on another rage of this book.

\section{HORTICULTURE BUILDING.}

Flowers in profusion will welcome the visitors who enter the Exposition grounds by the Elmwood gate. The handsome and commodious building to the left, surmounted with a lantern roof, rising to a height of 240 feet, is the Horticulture building. Square in plan and connected by glass-roofed arcades to the Graphic Arts building on the north, and the Mines building on the soith, the thrce buildings forming a semicircular court in front, facing the western Esplanade Fountain. The central, or IIorticulture, building can be reached from the west by following along the Western Midway road until the canal bridge is reached or from the east directly from the Esplanade. At each of the four corners of the building is a tower, octagonal in design and capped with a dome. The walls of the building are covered with bas reliefs, fwining vines, etc. It was designed by A rchitects Peabody \& Stearns of Boston, Mass. In this building will be found all the popular fruits of the different countries represented in the exposition, and a refrigerating plant on the grounds malies it possible to provide a daily supply of fresh fruit. Artic!es and appliances used in horticulture mal:e up a large part of the exhibit. In the conservatories which connect this building with the others are rne exhibits of hot-house plants.

The cost of the building was about $\$ 240,000$.

For list of exhibitors and spaces, see the floor plans appearing on another page of this book. 
The Pan-American Official Catalogue and Guide.

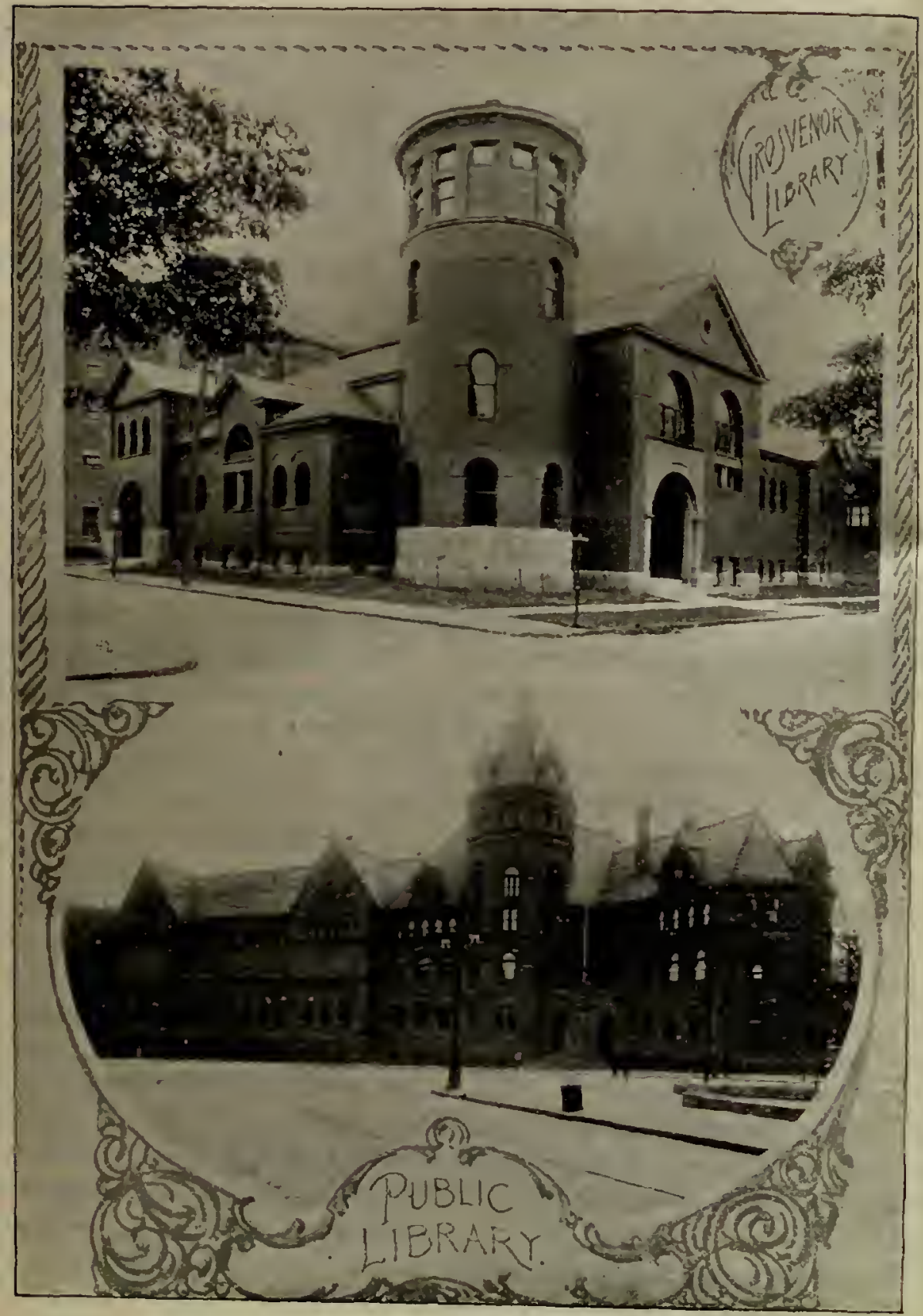


The Pan-American Official Catalogue and Guide.

\section{THE MINES BUILDING.}

At the southwestern end of the Esplanade and connected to the Horticulture building by an arcade which is used as a conservatory for flowers, is the Mines building. Square in design, with four square corner towers and a loggia of three arches forming the entrances to the building, which is lighted by means of a glass skylight in the center of the roof. The building has a floor space of thirty thousand square feet and was designed by Architects Peabody \& Stearns of Boston, Mass. In this building is found an extensive exhibit of mines and metallurgy. Minerals of every description, both useful and ornamental, are fully represented. The methods and processes employed in the treatment of ores and the means cmployed in bringing them from the earth can be studied by those intcrested. All parts of the United States, and every country of South and Central America, Canada, Mexico, and the islands of the sea have contributed to the exhibit. All kinds of machinery used in the manipulation of ores is shown. Taken altogether the Mines building is one of the rare attractions of the Exposition.

List of exhibits appeal's on another page of this book.

\section{THE TEMPLE OF MUSIC.}

The Temple of Music, one of the most beautiful of the Exposition buildings, is situated west of the central fountain of the Esplanade and south of the Machinery and Transportation building. It is a squareshaped building, the arched entrances at the corner giving it a circular appearance. It is surmounted by a tower covering the entire building and this is covered with a dome rising 180 feet above the main floor. The building is colored in light yellows, with gold and red trimmings, and the panels in the dome are in light blue, producing an extremely beautiful effect. The building occupies a space 150 feet by 150 feet, and was designed by Architect Aug. C. Esenwein of Buffalo, N. Y., and cost $\$ 85,000$.

It provides an auditorium capable of seating 2,200 people, and con- tains one of the largest pipe organs ever built in the United States, and daily organ recitals are given by the most celebrated organists of this country and Canada. The organ is the work of Emmons Howard of Westfield, Mass., and is equipped with all the latest improvements known to organ builders. The principal national holidays will be observed with musical festivals, and many of the most famous hands of both the New and Old Worlds will give conccrts in the Temple of Music, and from the various other band stands of the Exposition grounds. 


\section{The Pan-American O.ficial Catalogue and Guide.}

\section{THE GRAPHIC ARTS BUILDING.}

In size and form the Graphic Arts building is similar to the Mine: building and was designed by the same architects, Peabody \& Stearns of Boston, Mass. It is located at the western end of the Esplanade, abd is connected to the northwestern end of the Horticulture building bs means of an arcade, in which are blossoming hot-house plants. En trances are provided on each of the four sides of the building, through a loggia of arches. In this building will be found a most timely display, illustrating the remarkable progress of printing and its allied arts.

\section{GRAPHIC ARTS WORKSHOP.}

This is the building directly west of the Horticulture building and on the opposite side of the callal. It is a low building with its over. hanging eaves forming an open portico, surrounding the entire siruc. ture, and flanked by rows of columns. The building is $140 \times 40$ feet and is used, as its name implies, as a workshop for the Graphic Arts depart. ment. The exhibits are in lithography, printing, engraving. bookbind. ing, electrotyping, stereotyping and other kindred trades. The archi. tects are Carrère \& Hastings of New York.

\section{THE ETHNOLOGY BUILDING.}

The Ethnology building occupies a very prominent place in the group of main buildings. It is opposite the Temple of Music, from which it is separated by the cascade fountain, and is, therefore, situated at the northern side of the Esplanade. The building is circular in form with a diameter of 150 feet and four arched entrances are equally spaced around the circumference of the building. The building is surmounted by a dome covered with red tile, while the color scheme for the sides is light yellow. It was designed by Architect George Cary of Buffalo. In this building are exhibits of great historical interest; relief mans of Niagara Frontier, showing sites of the Indian Village, and the results of researches into the origin, the filiation, the custnms and institutions of wild and barbarian tribes still existing, or of whom we have authentic records.

The cost of the building was $\$ 88,000$.

\section{WOMEN'S BUILDING.}

As one enters the Elmwood gate, the building directly ahead and on the east side of the Horticultural Gardens. is the Women's building.

A frame structure, formerly the home of the Country Club. 
The Pan-American Official Catalogue and Guide.

In addition to the offices, the building contains a number of beautiful tea rooms and reception rooms, all opening into a large hall, which is planned to serve as a reading room, when not in use for entertainments.

On the main floor of the building will be found a buleau of registration where club women are invited to leave their addresses, so that the building will serve as headquarters for clubs and organizations.

Here the Board of Women Managers of the Exposition will receive and entertain all the honorary members of the Board, the various clubs and other noted guests.

\section{NEW YORK STATE BUILDING.}

This is the first building to the right or south of the Elmwood gate, and is an edifice of substantial and enduring character. The architect was George Cary of Buffalo, N. Y., and the cost $\$ 375,000$. The exterior of the building is entirely of white marble, and in style of architecture it resembles a Grecian temple of the Doric order. The dimensions of the building are $85 \times 130$ feet, the height is 33 feet on the north wall and forty feet on the south wall. In the basement are the boiler rooms, bicycle rooms, etc. The building is provided with a dining room con. taining about 2,000 square feet, and over 10,000 square feet of floor space is taken up by the museums. After the Exposition the building hecomes the permanent home of the Buffalo Historical Society, whose large collection of pioneer relics it contains.

\section{THE STADIUM.}

The Stadium for athletic sports, as its name implies, is modeled after the Panathenaic Stadium, scooped by Lycurgus out of the banks of the Ilissus, at Athens, 2200 years ago. It is situated to the left or enst of the Plaza as one enters by the railway gate.

The dimensions of the ancient stadium were 680 feet in length and 130 feet in breadth, while this modern copy is 840 feet long and 400 feet wide. The present interest in athletic sports has been handsomely recognized in this fitting monument to their popularity.

The nature of the sports planned is varied. Amateur as well as professional events of all kinds will be held, and will include baseball, football, cycling, shooting, lacrosse, Caledonian games, cricket, tennis, and other sports. The Stadium contains a quarter-mile racing track and ample space for all the popular athletic games, with a seating capacity in the stands of over 12,000 .

Here also will be the displays of livestock, automobiles, and other road vehicles, farm and road machinery in motion. City.

The structure was designed by Architect Walter Cook of New York 
The Pan-American Official Catalogue and Guide.

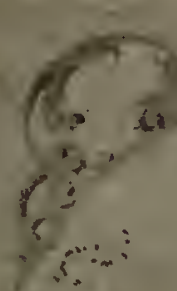

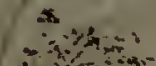

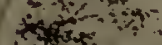

f.

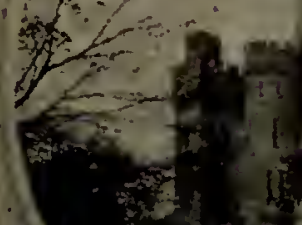

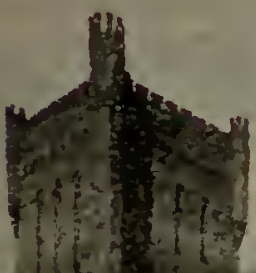

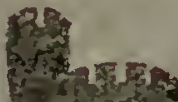

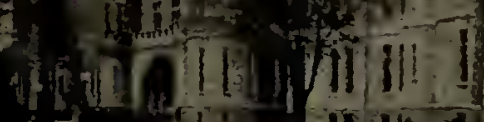
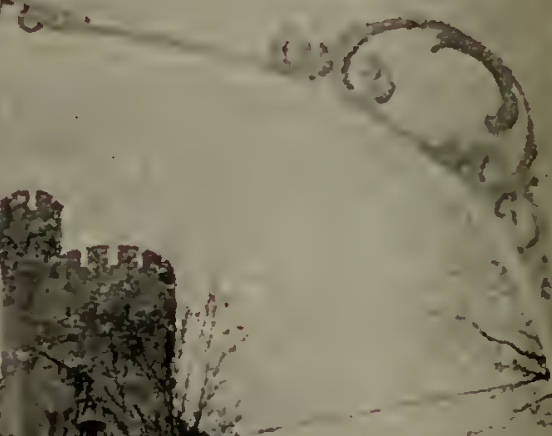

(11)

- ir un tir

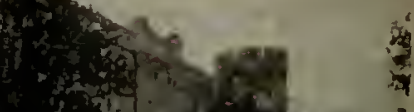

$\sqrt{\cos 2}$

susure

.

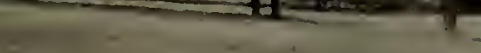

$-2=20 x+2$

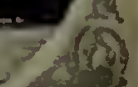

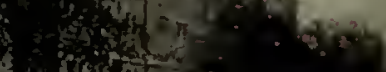
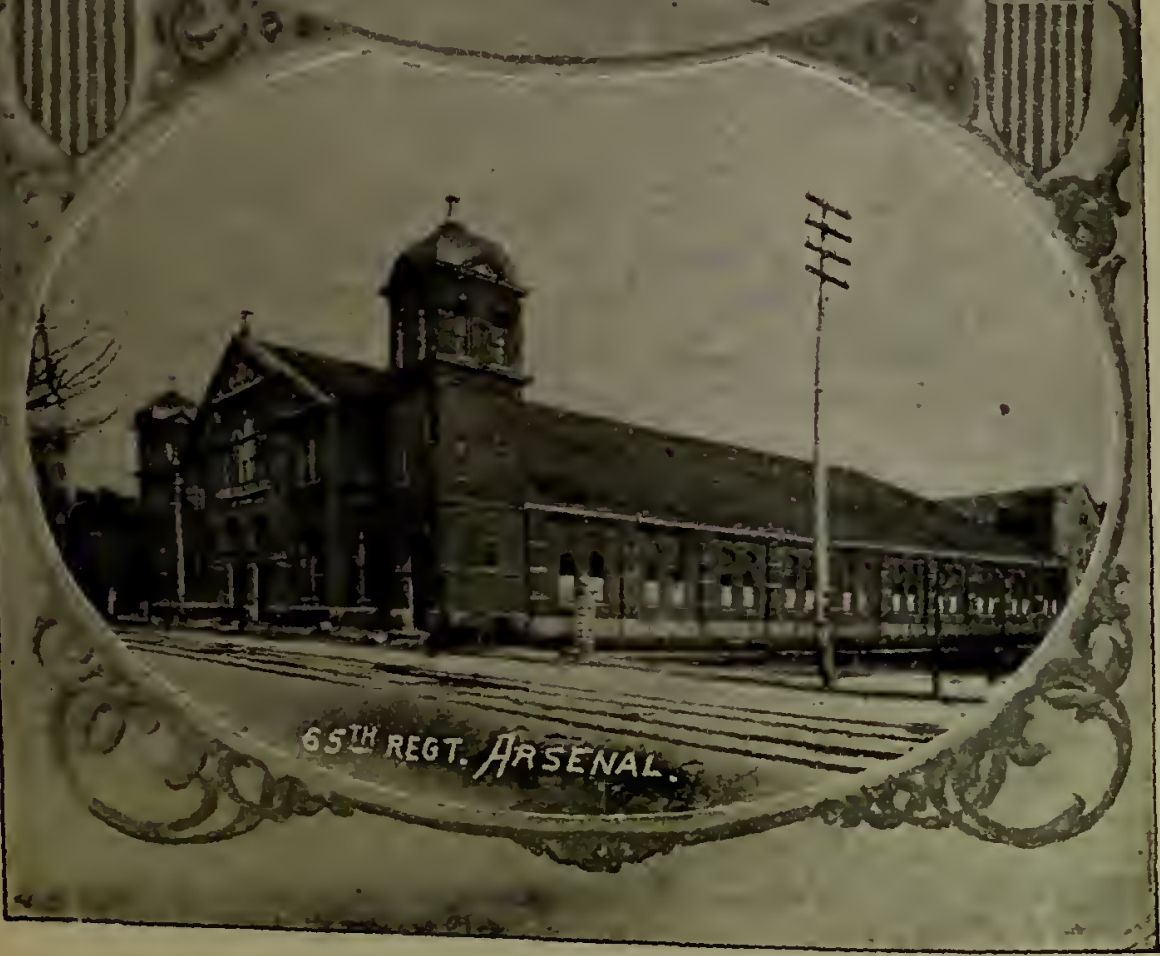
The Pan-American Official Catalogue and Guide.

\section{THE ART BUILDING.}

The extremely high charactel of this exhibit makes it especially interesting to all art lovers. All that was best in the many Expositions recently held has been obtained, together with the choicest pictures in many private American collections. The exhibit of paintings and sculpture, thougl not as large and varied as that of the World's Fair, is thoroughly creditable, and the building of Fine Arts ought to be the most interesting spot on the grounds to cultured people and especially artists. It is situated in the southeastern part of the grounds, directly in front of the Meadow gate, a brick fireproof luilding 225x100 feet, provided with entrances on the north and south sicles, and was designed by Green \& Wicks of Buffalo, N. Y.

The Albright Art Gallery, which is in an unfinished condition and in the extreme southwestern part of the Exposition grounds, was to have been used for the Pan-American gallery, but owing to some difficulties met with in the course of its construction, it could not be completer in time, and thus the Exposition lost one of its most beantiful buildings.

\section{THE ORDNANCE BUILDINGS.}

The buildings, two in number, for displaying the exhibits of ordnance are located in the southeastern section of the grounds, and south of the section occupicd by the state and foreign buildings. On entering the grounds by way of the Meadow Gate, they are the two large buildings to the right. Alike in design and each occupying a space $100 \times 50$ feet. The roofs are of red tile with overhanging eaves and the outer walls ale colored in light yellows. This is a collective commercial exhibit, everything representing something purchasable, in contradistinction to the government exhibit, located at the north end of the United States Government building. All the largest builders of arms and ammunition are represented, and it undoubtedly is the most complete exhibit of ordnance ever shown. Between the two buildings a Gruson turret, 55 feet in diameter, has been constructed and a model 12-inch gun has been mounted within. This type of gun represents the largest which will now be manufactured in this country for coast defense purposes. The turret and its equipment are the first exhibit of the kind ever made in the United Strtes, and illustrate the newest step made toward an impregnable form of defense. The exhibit is so arranged that visitors may go inside and examine at will the entire interior, the magazine, the method of supplying ammunition to the gun in time of war and various contrivances tor efinciency of scrvice when it is required. The display has been in charge of U. S. Lieut. Godfrey Carden. 
The Pan-American Official Catalogue and Guide.

\section{ACETYLENE BUILDING.}

West of the Manufactures and Liberal Arts building and separated by the canal, is the building in which the exhibits of acetylene gas ap paratus will be displayed. It occupies a space $100 \times 30$ feet and in design and color conforms with the surrounding buildings.

\section{STATE AND FOREIGN BUILDINGS.}

In the southeastern section of the grounds and directly south of the U. S. Government buildings are the various and attractive structures erected by the states and foreign countries participating in the Exposition.

The Illinois building-Crossing the bridge at the east end of the Fore Court, this is the second building to the right. A two-story struc. ture, 40x80, with a large verandall on the north side. The entire floor space is taken up by exhibit and reception rooms. The State appropria. tion was $\$ 75,000$.

Michigan building-Southwest of the Indian Mounds, which are about in the center of the space allotted to Staie and Foreign buildings, is the building elected by the State of Michigan. It occupies a space $70 \times 45$, and is two and one-half stories high. A wille porch surrounds the building on all except the south sides, furnishing a pleasant and cool retreat for the visitors. The State appropriation was $\$ 40,000$.

New England building-The New England States have combined and are all represented in one large building. It is situated west of the Michigan building, and the best way of approaching it is by crossing the bridge on the east side of the Fore Court. It is a handsome colonial structure, $100 \times 50$ feet, two stories high and its flat roof is surrounded by a balustrade. The appropriations from the different States were: Cornecticut, $\$ 25,000$; Massachusetts, $\$ 15,000$; Rhode Island, $\$ 30,000$.

New Jersey building-This is the one-story structure north of the Ordnance building. It occupies a space about $35 \times 35$, which is used almost entirely for reception rooms. The building has large overhanging eaves, and has its entrance on the east side. The State appropria. tion was $\$ 25,000$.

Ohio building-ovellooking Mirror Lake and north of the Illinois building is the structure built by the State of Ohio. Rectangular in shape, two stories high, a capacious porch and balcony surrounding the entire building. The space occupied by the building is $80 \times 120$ feet and the State's appropriation was $\$ 30,000$. 
The Pan-4merican Official Catalogue and Guide.

Pennsylvania building-West of the Foiestry building is the structure erected by the State of Pennsylvania. A two-story building, $30 \times 30$, surmounted by a dome, a verandah extending around all sides. The State appropriation was $\$ 35,000$.

Wisconsin building-This building is the first building to the right as one crosses the bridge from the east side of the Fore Court. It is a two-story building, 50x50 feet, with gabled roof and has an extremely large and ornamental verandah on its western end. The State appropriation was $\$ 25,000$.

Besides the exhibits contained in the various State buildings, these States, as well as the following, are well represented in the other departments of the Exposition: Washington, Oregon, Idalio, North Dakota. Alabama, Minnesota, Missouri, Nebraska, Georgia, Kentucky, Montana, Mississippi, Louisiana, Texas and California (by the Los Angeles Chamber of Commerce).

\section{CANADA BUILDING.}

The splendid building situated between the Dairy building and the Stadium, is that erected by the Canadian Government. It consists of two buildings, each three stories high, and connected by a two-story arcade. The space occupied by the buildings is 2,500 square feet, which is ussd as reception rooms, reading rooms and partly for exhibits, although the Canadian Government has made extensive exhibits in the various Exposition buildings. The Govcrnment appropriation was $\$ 112,000$.

\section{LATIN-AMERICAN COUNTRIES AND BUILDINGS}

The Argentine Republic appropriated $\$ 30,000$ go!d for its exhibits at the Exposition, and occupies 1,500 square feet of space in the Forestry building, and 3,700 feet in the Agriculture building. The wonderful resources of that country are but little appreciated by the public and this opportunity to study them is worthy of very general attention. The Republic is represented by Licut. John S. Atwell.

Bolivia has 2,400 square feet of space, distributed in the Agriculture, Mining and Ethnology buildings. The country is particularly rich in its mining resources. Bolivia is represented by Senor Don Ramon Pandohijo, son of the President.

Brazil-A "Brazilian Fazenda" in miniature is a part of the exhibit from this country. It is situated soltheast of the Fore Court, and north of the Honduras building, and illustrates the cultivation of coffee, rupher and other products. Brazil also occupies 500 square feet of space in the Agriculture building. 
The Pan-American Official Catalogue and Guide.

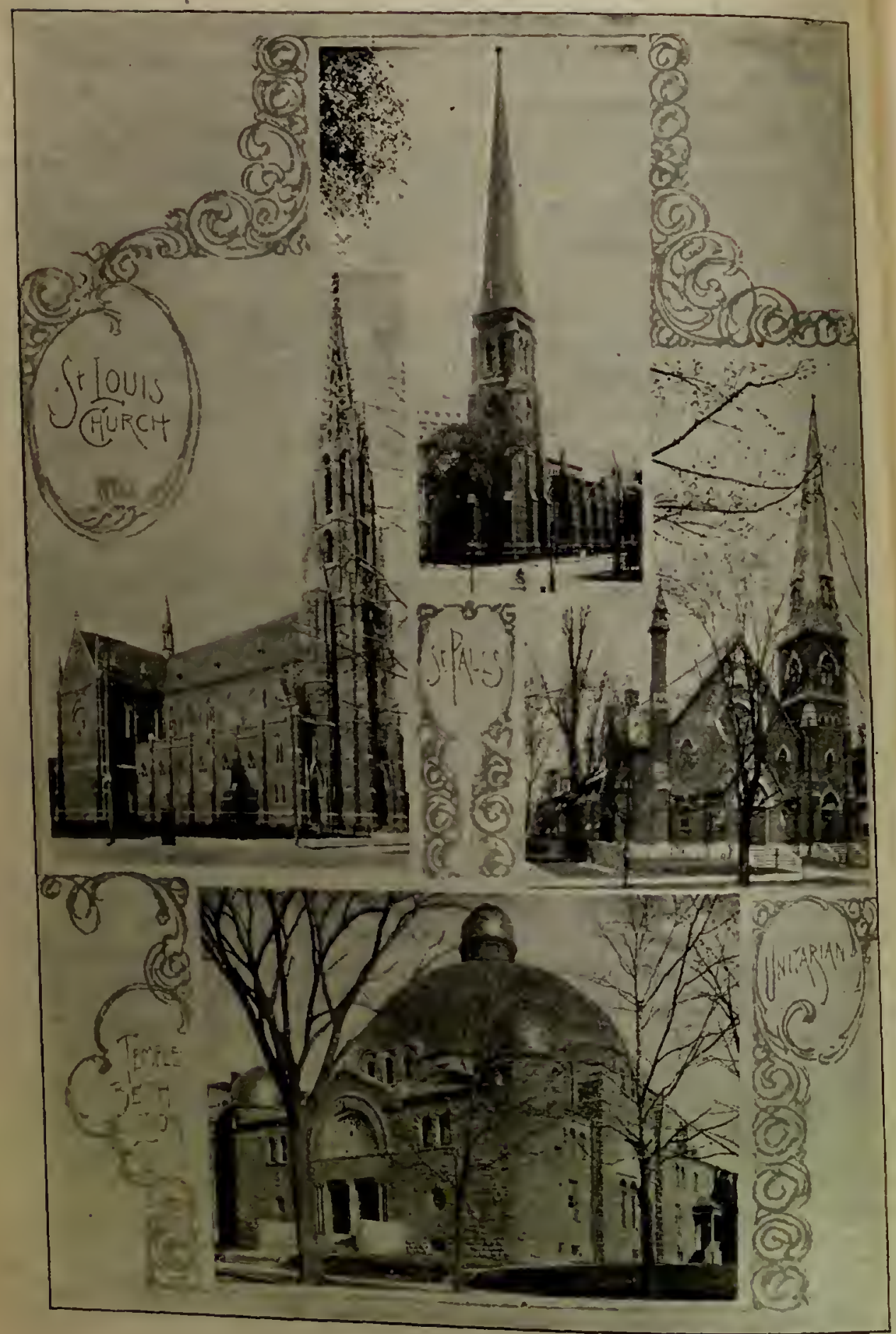


The Pan-American Official Catalogue and Guide.

Chili makes a magnificent showing, having appropriated a larger sum than that of any other country for her representation at the Exposition, $\$ 170,000$ gold. Its building, which is one of the most minue in design, cost $\$ 2 \$, 000$, and the exhibit is a magnificent one, showing her wonderful advance in culture and all the arts of civilization. Chili is represented by a commission of eleven members, with Senor Don Enrique Budge, Commissioncr General.

Colombia is represented by Senor Dr. Luis Cucrvo-Marques, special Commissioner, but has no exhibits.

Custil Rica occupies 1,660 square feet in the Iorticulture, Forestry, Ethmology and other buildings, having some very interesting features. Her representative is Senor Di. Juan J. Ulloa.

Cuba is represented by a commission of which Senor Don Perfeeto Lacoste is chairman. The Cuban building is $50 \times 75$ feet, cost $\$ 25,000$, aud is the second building east of the Forc Court approaeh. A collection of exhibits of surprising excellence has been arranged for the inspection of those who are interested in this new insular nation.

The Dominican Republic is represented by Senor Don Francisco Leonte-Vazquez, special commissioner and two other commissioners. This country has erected a speeial building, west of the Ordnanee exhibit buildings, costing about $\$ t, 000$, and supplying space for a rery attractive exhibit of her resources.

Ecuador is represented-by a speeial building, located southeast of the Indian Mounds, having appropriated $\$ 16,000$ for her representation. Senor Don F. Mora Silva is the speeial commissioner.

Guatcmala occupies about 1,100 square feet of exhibition space in several buildings and her special commissioner is Senor Don Albert Niquet.

Hayti makes a special exhibit of agricultural products.

Honduras has a graeeful building, west of the Fore Court and adjoining the same, eosting about $\$ 6,000$. Her principal exhibits are those of mines and forestry, as her resources in these ploducts are of signal importance and value. The Ethnological exhibit is also important and valuable.

Mexico has a two-story building, nortl of the Ordnanee building; it is 40 by 60 feet, costing $\$ 5,000$, containing only the mining exhibits from that country. Mexico also occupies space to the amount of 3,000 square feet in the Agriculture building; 2,000 feet in the Forestry; 2,000 feet in the Horticulture; 3,000 feet in the Manufactures, and 2,000 feet in the Ethnology building. The Mexican Government is represented by a commission of her foremost eitizens, of which Senor Ingeniero Don 
The Pan-American Official Catalogue and Guide.

Albino R. Nuncio is chicf. Mexico also sends a company of mounted Rurales and a Military Band of 62 pieces, which will be quartered upon the Exposition grounds.

Nicaragua occupies important space in the Mining, Horticulture, Agriculture and Ethnology buildings. Senor Don Luis F. Corea is chairman of the Nicaraguan Commission.

Pcru occupies space in the Agriculture, Manufactures, Forestry and Mines buildings, and makes a very interesting showing of her valried innortant products.

Porto Rico is represented by Senor Don Jose T. Silva, claairman and two other Commissioncrs. The Island Government is spending $\$ 10,600$ upon its exhibits. 'A typical Porto Rican "Rancho" 24 by $7 \delta$ feet and 20 feet high, costing about $\$ 2,000$, contains most of the exhibits from that Island, and is the first building west of the New England building. About 1,200 square feet of space in the Agriculture building is also occupied by Porto Rico.

Salvador makes a good showing of her mineral, agricultural and forestry resonrces in about 2,000 square feet of space. Senor Dr. Dario Gonzales is chairman of the Salrador Commission.

Uruguay and Venczuela are represented only by individual exhibitors. Venezucla appropriated $\$ 100,000$ for an exhibit but political disturbances compelled an abandonment of the project.

Jamaica is represented by the Agricultural Society, which has space in the Horticulture and Agriculture buildings, in charge of $\mathrm{Mr}$. Barclay Bouchier Chadwick.

\section{THE DAIRY BUILDING.}

Separated from the Agriculture building by the canal, and the third building to the right as one enters the East Amherst gate, is that occupied by the cxhibits of the dairy. It is of the Swiss style of architecture, and is of very clever design, descrving of spccial mention in this particular. In the center of the building is an exhibition case cxtending almost the entire length, carefully insulated, in order that its contents shall preserve that freshness which is always the charm of a wellkept dairy. Exhibits are arranged along the sides of the building and cooling plants are provided.

For list of. exhibits see another page of this book.

\section{BAZAAR BULLDING.}

This building has been laid out with special reference to the needs of Concessionaires who have for salc rarious linds of wares, sonvenirs, etc., as may properly be sold within the Exposition grounds. Mr. W. W. Bosworth of New York is the architect of this building. 
The Pan-American Offeial Catalogue and Guide.

It is situated on the Mall, west of the Electricity building, being separated from it ly the canal, and was lunilt along the same general architectural lines as the other Exposition buildings.

In this building will be found the Post Office, Telegraph Office, Express Offices and Newspaper Headquarters.

\section{THE SERVICE BUILDING.}

To the right of the Mall as one enters the Amherst gate is the service building. This was the first building built on the grounds, and is used as an office and administration headquarters for the Exposition Company. It is a two-story building $150 \times 100$ feet, with a ligit yellow coloring and is provided with an interior court for the lighting of the various interior offices.

\section{THE ROSE AND HORTICULTURAI, GARDENS.}

This outdoor display is situated in the southwestern part of the grounds, and begins directly in front of the Elmwood gate. Prominent nurserymen from various parts of the country have made exhibits of nursery stock, including orchard and ornamental trees, shrubs and evergreens, and prominent florists generally have planted over 500 beds of floral exhibits in the seven acres set apart for these displays. This inclucles every variety of the popular flowering plants. When certain flowers are at their best, special exhibitions will be held, and the public may have the pleasure of inspecting wonderful displays of roses, dahlias, gladioli, sweet peas, chrysanthemums, cannas, etc.

\section{SIX NATIONS' STOCKADE.}

South of the U.S. Government building is the living exhibit of the Six Indian Nations. A stockade las been luilt and a typical historic Indian village is reproduced, bringing the visitor back some three or four luunired years ago. The Indians, who are representatives of all the tribes, will follow the customs of their early ancestors in making weapons, utensils, tools, dolls and knick-knacks, and these articles will he offered for sale. In the center of the stocliade is a reproduction of the famous council house of the Iroquois. The exhibit is of special value to students, as interpreters are provided so that they may talk with the Indians themselves.

\section{FORESTRY EXHIBIT.}

This exhibit is appropriately housed in a building of rough logs. south of the U.S. Government buildings and separated from them by the canal. On entering the Meadow gate and walking northrvard till 
The Pan-American Official Catalogue and Gidle.

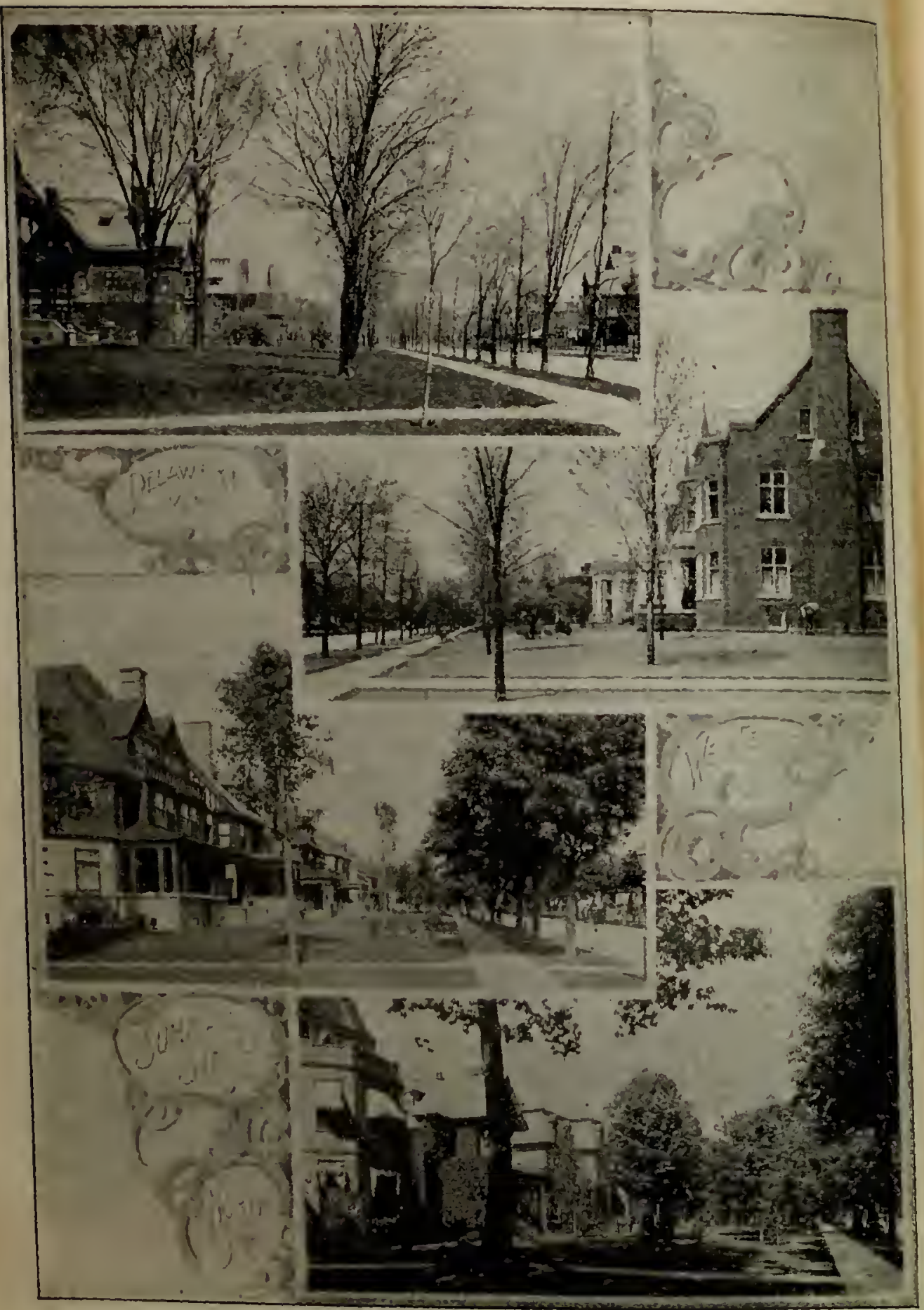


The Pan-American Official Catalogue and Guide.

the second crossroad is reached, it is the second building to the left. It is $100 \times 150$ feet in size and contaius exlribits from most of the South and Central American countries, as well as complete ones from the United States and Canada.

\section{PRESS BUILDING.}

Situated on the south Midway and west of the Horticulture building, is the buidling provided for the department of publicity. It is a two-story frame structure, $75 \times 60$ feet, and the color scheme adopted is in light browns and yellows. The space in the building is used for offices and for the accommodation of the press representatives.

\section{GRANGE BUILDING.}

This building is the headquarters for the grangers and farmers. It is equipped with a register, postoffice facilities, check roon for baggage, and reading room where 150 agricultural papers are on file.

Through the State and National Granges, arrangements have been perfected with the Keese Information Company to assign visitors to private residences, boarding houses and hotels.

\section{LIVE STOCK.}

To the left as one enters the East Amherst gate are the buildings for this exhibit, covering an area of about 10 acres and with a capacity for housing 2,000 animals; fifteen in number and proviled with all modern conveniences for the healthful care of stock of all kinds. In this department, owing to the large number of applications for entry great care has been taken that the exhibits shall consist of nothing excent the finest specimens of each particular class.

Bench Show-August 27th to August 30th.

Swine-August 26th to September 7 th.

Cattle--September 9 th to September 21 st.

Sheep-September 23d to October 5th.

Horses-October 7th to October 19th.

Poultry-October 21st to October 31st.

Pet Stock-October 21st to October 31st. 
The Pan-American Official Catalogue and Guide.

\section{REST AURANTS.}

Ample provision has been made for the accommodation of visitors in the following large restaurants, besides those located in the different villages and concessions on the Midway, lunch stands, \&c.

At the entrance to the Midway, on the west side of the Plaza.

At the entrance to the Stadium, on the east side of the Plaza.

On the south Midway and west of the Horticulture building.

On the Mall and east of the Manufactures and Liberal Arts building

On the Lake, to the right of the Lincoln Parkway gate.

In the Electric Tower-take elevator.

North of the Ordnance building.

East of the Forestry building.

East Amherst St. entrance.

\section{ROUTES OF THE GONDOLAS.}

At various points along the canal are little latticework stations, with landings and awning-shelters. The stops are:

One on the bank of the canal east of the Mall bridge.

One on the bank of the canal west of the west Mall bridge.

One on the east bank of the canal, east of the Government building and under the protection of the frowning muzzles of the big guns of the ordnance exhibit.

One on the southwest corner of the canal system, just at the Six Nations Indian village.

One cast and one west of the causeway of the Grand Approach on the west bank of the canal.

One on the west bank of the canal, west of the Mines building.

One at the bridge entrance to the Horticulture building.

One on each side of the bridge across the canal that forms the entrance to the Electric Tower.

One at the foot of the stairs leading to the canal path, opposite the Electricity building.

One at the foot of the stairs leading to the canal path, opposite the Agriculture building.

\section{HOSPITAL BUILDING.}

An emergency hospital on the grounds has been provided by the Exposition Company. A competent staff of physicians will be found in attendance constantly. It is the first building to the right as one enters the Amherst gate. The structure is $30 \times 100$ feet and is provided with well-equipped operating rooms, sleeping rooms, etc., such as are in any up-to-date hospital. 
The Pan-American Official Catalogue and Guide.

\section{A. O. U. W. BUILDING.}

South of the Illinois building, in the section of the grounds allotted to the Siate and foreign buildings, is the structure erected by the Ancient Order of Uniled Workmen. It occupies a space about $30 \times 30$, and is designed after the Spanish style of architecture. An op=n portico surrounds the entire second story, its overhanging eaves furnishing a cool and delightful resort for all visitors. The entire floor space is taken up with reception rooms where the members will congregate.

\section{MACCABEES BUILDING.}

This very unique building, erected by the Knights of Maccabees, is located just west of the Forestry building, and is best approached by way of the walk leading south from the U. S. Government building. The building is about $30 \times 30$, and on its western end has been erected a square tower, giving the structure the appearance of a miniature castle. Every convenience has been provided in the way of reception rooms, lodge rooms, etc., and members of the order will find this building a convenient meeting place.

\section{LOWNEY'S CHOCOLATE EXHIBIT BUILDING.}

Situated on the north side of the Canal Bridge which approaches the Horticulture building from the east and Midway side. The building is three stories in height, the first floor being devoted exclusively to the sale of Lowney's cocoa, chocolate and chocolate bon-bons. On the second floor is located the exhibit of Lowney products, ladies' waiting room and office. The upper floor is a beautiful roof garden, which is well worth a visit for the fine view obtainable.

\section{BAKER'S CHOCOLATE BUILDING.}

This building is west of the Horticulture building, and opposite the Lowney building. It is two stories high and is surmounted by a square shaped dome. The lower floor is used for the display of chocolate, cocoa, etc., and around the balcony tables are arranged for visitors while being served with refreshments.

\section{MISSION BUILDING.}

This very unique building is located morth of the Dairy building and separated from the Agriculture building by the canal. It consists of a central or main building surmounted by a dome, and has two wings extending west and south, respectively, from the same. The structure is a reproduction of a Mexican Mission building and contains the exhibits of The J. \& R. Lamb Co., The Buffalo Pitts Co., The M. I. Birge Co., and The Aeolian Co. Aeolian recitals will be given daily. 
The Pan-American Offcial Catalogne and Guide.

\section{STANDARD PAINT CO. BULLDING.}

This is located just north of the Grange Building, and is the struc. ture used by that firm at the Paris Exposition. The exhibit is of the various kinds of paints, oils, varnishes, etc.

\section{DRAKE BUILDING.}

This is the building located on the Mall, and south of Alt Nurnberg. The entire building is covered with bark and the exhibit consists of various specimens of petrified woods as made up into the different articles mannfactured by the Drake Co.

\section{CAMERA PRIVILEGES AT THE PAN-AMERICAN EXPOSITION}

May be enjoyed upon payment of 50 cents per day for each instrument and a somewhlat less rate when permit is taken out for a week, the only limitations being that no tripods be nsed and the plates must not be larger than $4 \times 5$ inches.

\section{PAN-AMERICAN STAMPS.}

The series of stanps issued by the Government is said to be "the most artistic series ever issued from the department," and includes the following:

One cent (green) - The lake steamer presents the port bow, the pilot house is well forward and it is propelled by side wheels.

Two cent (red)-The train of four cars is drawn by a locomotive with four drivers; four parallel tracks are shown.

Four cent (red-brown) - The automobile is of the closed coach order. with two men on the box and a part of the United States Capitol at Washington as a background.

Five cent (blue)-This presents the largest single span steel bridge in the world; two trolley cars are seen upon it, and a full view of Niag. ara Falls is shown under, beyond and up the river with the graceful springing arch as a frame.

Eight cent (lilac)-The great ship canal locks at Sault Ste. Marie, Michigan, are given in a view from a higher point, including the immediate surroundings.

Ten cent (light brown)-An ocean steamship of the American Line, with two smokestacks and masts, presents its starboard bow lapped by a rising wave. 
The Pan-American Official Catalogue and Guide.

\section{SCULPTURE AT EXPOSITION.}

FOUNTAIN OF KRONOS-Western wing of Esplanade. FOUNTAIN OF NATURE-Western wing of Esplanade. FOUNTAIN OF PROMETHEUSMINERAL WEALTH-Near Mines building. PEACE AND PLENTY-U. S. Government building. RELIGIOUS MUSIC-Temple of Music. GAY MUSIC-Entrance to Temple of Music. HEROIC MUSIC-Entrance to Temple of Music. SACRED MUSIC-Entrance to Temple of Mnsic. GODDESS OF LIGHT-Surmounting Electric Tower'. PAN WITH AMOR-East end of Proplyra. TWO TORCH BEARERS-Niches in Electric Tower. FLORAL WEALTH-Western wing of Esplanade. THE ARK-Group in Court of Fountains. THE SCIENCES-Group in Court of Fountains. STANDARD BEARER-On Triumphal Bridge. CHARIOT RACE-Near New York State building. AGRICULTURE-Group in Court of Fountains. AGE OF ENLIGHTENMENT-East wing of Esplanade. COURAGE-Triumphal Briclge. VICTORY-Triumphal Brilge. QUADRIGA-On Dome of U. S. Government building. HORSE TRAINER-Near Live Stock buildings. PATRIOTISM-Triumphal Causeway. RESTING BUFFALOES-In Sunken Gardens. HOSPITALITY-On Triumphal Bridge.

For detailed description of Art and Statuary, see oflicial Art Inuabook, edited ly Mr. David Liray, anrl scid on the grounds. 
The Pan-American Official Catalogue and Guide.

\section{The Midway.}

Chiefly for the want of a better name, the amusement section of the Exposition has followed in the wake of Chicago, and been called "Tht Midway." The very large area lying in the northwestern end of the grounds has been allotted to the concessionaries whose business it is th amuse and at the same time instruct the visitors.

Here are found foreign villages with picturesque types of architee ture and the curious and interesting evidences of civilization, so differ ent from our own.

In modern expositions the Midway has come to be a fixture, and without it the Exposition would lose much of its charm. Visitors to all of the great National and International shows carry away with them the most pleasant recollections of scenes in the amusement see tion. This part of the Pan-American does not consist of mere funmaking exhibitions, but in addition to the legitimate amusement which is afforded visitors, there is much that is instructive and proitable.

Great care has been exercised by the Exposition management in making the concessions for these attractions, which, having passed through a period of evolution and development, have attained a degret of splendor quite impossible a few years ago.

Entering the Midway through the Plaza entrance, we give below a brief description of the attractions as they appear.

\section{THE ESQUIMAU VILLAGE.}

Genuine Arctic life, presented by representatives of three tribes of Esquimaux from Hudson Straits, with all their home belongings - dog teams, sledges, topeks, kayaks, weapons, etc. The Esquimaux are em. ployed curing skins, carving ivory, manufacturing seal-skin clothing, etc. They present, in an ice-grotto, typical Esquimau dances, chants and ath. letic games, dog-races, also aquatic sports on the lake. The most instruc. tive and entertaining ethnographic exhibit in the Midway. Special rates to schools and colleges.

THE MOORISH PALACE (PAN-OPTICON).

Is the first building on the left as one enters the Midway. Nothing at the Fair-certainly nothing on the Midway-is potent for more good in an educational serise than the Moorish Palace. It illustrates in a most vivid manner, scenes and events from the history of every country on the globe. Here may be found many pleasing features for those in stareh of amusement and for the lover of art a rare treat is in store.

\section{GLASS FACTORY.}

A glass factory in full operation-illustrating the process employed 
The Pan-American Official Catalogue and Guide.

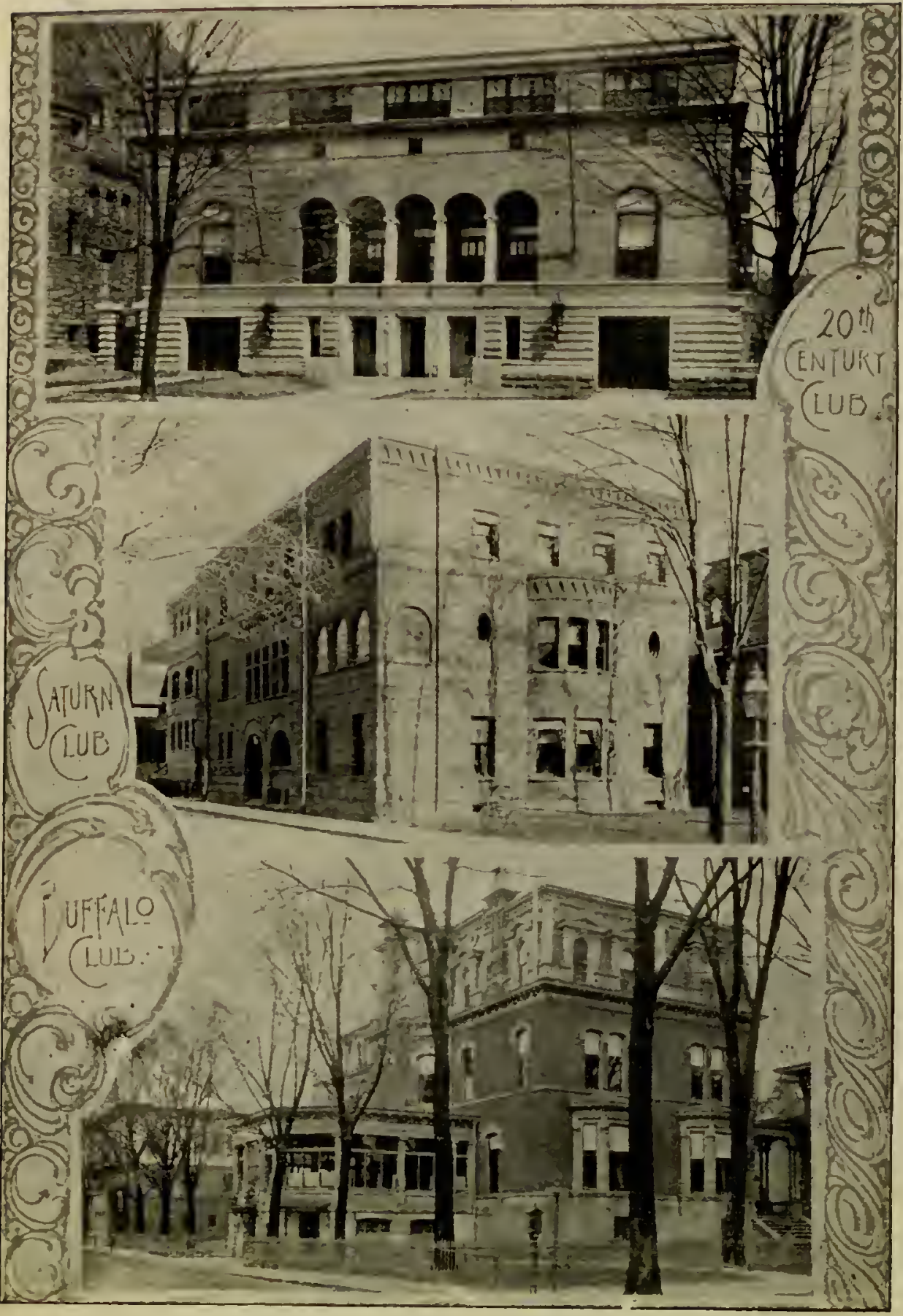




\section{The Pan-American Official Catalogue and Guide.}

in the manufacture of all kinds of glassware, from the raw materials to the finished products. Articles are made in the presence of the visior and offered for sale.

\section{MCGARVIE'S STREETS OF MEXICO.}

This is one.of the most pretentious and complete of the Midway exhibits. It includes a restaurant, market, dance hall, an old rural village, with the genuine adobe huts, a theater in which the native danees and songs are given and a bull-ring in which can be seen the famous Mexican bull fights by native toreadors and imported Mexican bulls, Every feature of Mexican life is here represented with strict fidelity to the original, while the amusements and general atmosphere are identical with those of the sister republic. A Mexican band plays the peculiar native instruments and free outdoor entertainments are given at regular intervals. Bull fights at 2, 3, 4, 8 and 10 P. M., daily. Theater, 2 to 11 P. M., hourly.

\section{A TRIP TO THE MOON.}

Visitors are enabled to make a tour of the stars and planets, to really dart through space on a "Trip to the Moon." The tourist to the earth's satellite can recline upon his steamer chair and listen to sweet strains of music while soaring off into boundless space. Entering the atmosphere of the moon the ship drops slowly toward a sea of sunlit clouds and passing through it makes a landing on the moon. Guides meet each excursion party on the Landing Dock and show them to the wonderful underground city of the moon, with its palaces and shops, and hordes of queer people, and then on to the marvelous palace of the "Man in the moon," where all are welcomed by His Majesty, and are entertained with a revel of the "Maids of the Moon."

\section{THE THOMPSON AERIO-CYCLE.}

This attraction is the altitudinous novelty of the Midway. It resembles the "teeter" of boyhood days, constructed on a grand scale. It consists of two revolving wheels for carrying passengers, at the ends of a structural steel beam, and is so operated that when one wheel is down the other is at an altitude of 275 feet, affording a wonderful view of the Exposition.

\section{BONNER-THE EDUCATED HORSE.}

This exhibit is of the celebrated horse Bonner, the wonderful talking-writing equine comedian, who is possessed of intelligence almost luman, perforning examples in addition, subtraction, multiplication and division in the same manner as a human being, and giving perfect imitations of a mustang buck, pitch, rear and kick. 
The Pan-American Official Catalogue cnd Guide.

\section{FALL OF BABYLON.}

Next to the building occupied by Darkness and Dawn, or really in a part of that strueture, is the Fall of Babylon. The painting is by the famous French artist, George Rochgrosse, and represents a scene in Belshazzar's Temple. The army of Cyrus, the Persian, is seen entering the gates of the temple. Belshazzar's army, who spent the night in revelry, is surprised and Babylon taken.

The painting is extremely realistic and deserving of a generous patronage.

\section{DARKNESS AND DAWN.}

A realistie representation of a departed spirit, whose life on earth has not been exemplary. The visitor witnesses the punishment meted out to seandal-mongers, umbrella borrowers and other offenders. After the seas of fire are passed, beautiful seenes to delight the eye appear, so that the visitor may beeome aecustomed to the more familiar places above ground.

"Datrn" appears as a spectacular eulnination of superb electrical and scenie effeets.

\section{OLD PLANTATION.}

Presenting a veritable Old Southern Plantation, representing the "South be'fo de Wah," introducing 150 Southern darkies in their plantation songs and dances. Old Uncles and Aunties, formerly slaves, living in the genuine eabins in whieh Abraham Lincoln and Jefferson Davis were born, also other historical cabins from the Old South. A Georgia cotton field with real growing cotton and a grand cake walk on the levee, participated in by the entire eompany.

\section{AFRICAN VILLAGE.}

A eollection of some thirty-five different Afriean native tribes with their supremely ancient weapons, household gods and prinitive handicraft. Native workmen show their skill in working of gold and silver. The enelosure contains sections of large villages in their primitive state, with a theatre in whieh are given at times free exhibitions of native dances and entertainment. The folk songs and tales of equatorial Africa are given, showing the derivation of our negro melodies, and witchcraft tales. A Boer exhibit with hospital and trek wagons, various curios illustrating the war in Africa, with the hammock carriers and means of transportation of the great Afriean earavans.

\section{VOLCANO OF KILAUAE.}

A faithful reproduetion of the Burning Mountain of the Sandwich Isles. The spectator stands within an ex'inct crater of this perpetual 
The Pan-American Official Catalogue and Guide.

fire mountain, while its carmine hued fires belch forth and the streams of molten lava are forced from its cavernous depths. No lasting torment could be more horrible than the feeling which comes orer you as you gaze into the depths of this Inferno of the world.

\section{HAWAIAN VILLAGE AND THEATER.}

This attraction is especially interesting to visitors, since the life, customs, etc., of our new islani possession are represented. In the village one car see the whole modus of sugar and coffee culture, gigantic palms, and the rites and ceremonies of the islanders. In the theater are given the native plays by naive actors, introducing the famous Hu!nHulu dancing girls, who dance this graceful measure as it is only danced to royalty. The hulu-pahu and the alaapa-apa dances are also given for the first time in this country. For good wholesome fun this concession affords one of the best Midway attractions.

\section{MINIATURE WORLD'S FAIR.}

As its name implies, the World's Fair has been transported to the Pan-American Midway, and is here shown, though somewhat reduced in size, but still preserving its essential features. This attraction will prove of interest to those who did not attend the Chicago Fair, and will serve to refresh the memory of those who were more fortunate.

\section{ROLTAIR'S HOUSE UPSIDE DOWN.}

(Paliwe of Illusions)

This is the oddest attraction on the grounds and represents a real house standing on its roof and chimncys. The visitor enters through the roof and after passing through the various apartments (all appearing in topsy-turvy arrangement), reaches the grand palace of illusions, where twonty beautiful young women are shown in different living illusions, eleverly arranged with splendid settings. On the stage are shown four transformation illusions, one dissolving into the other and culminating with Roltair's masterpiece, "Niagara Falls."

\section{CLEOPATRA'S TEMPLE.}

The splendid building of Lgyptian architecture, directly opposite the House Upside Down. Here are shown a series of grand paintings illustrating events in the life of the Egyptian Qucen, culminating with Cooper's masterpiece, "Cleopatra," in which she is shown surrounded by her oriental splendor in a beautiful pose, and displaying her charms in order to captivate Antony. The paintings are extremely realistic, combining grace and beaty, and one almost believes the most beautiful woman in the wor!l is there in flesh. The exhibit is owned by Alonzo Lincoln. 
The Pan-American Official Catalogue and Guide.

\section{AROUND THE WORI.D.}

As its name implies, in this concession the visitor really enjoys a trip around the world. Native singing and dancing girls of the different countries render their peculiar songs and fascinating dances. By a very ingenious arrangement the surroundings a re almost instantly changed, representing the different countries as illustrated.

\section{MUTOSCOPE.}

Entrance to this attraction, being free, visitors may enter and satisfy themselves. Fully 150 moving picture or mutoscope machines, with an endless variety of subjects may be seen by dropping a "penny in the slot."

\section{COLORADO GOLD MINE.}

A faithful representation of a gold mine in working order, showing the manner cmployed in wresting the gold of commerce from the secret rock bound treasure troves of nature. On entering the mine competent guides explain the various drifts, veins and ledges.

This is not a model, but an actual reproduction of a Colorado mine.

\section{PABST'S PAVILION.}

In which the beer that made Milwaukee more famous, can be bought in quantitics to quench the thirstiest thirst, while the strains of an excellent orchestra delight the ear. Solid refreshments are also provided.

\section{AKOUN'S BEAUTIFUL ORIENT.}

A dazzling, realistic display of the charms of the far east, reproducing the streets, villages and encampments of the principal countries. Some of the most noted buildings, mosques and minarets are reproduced and occupied by hundreds of natives, traders, fortune-tellers, etc., occupying booths, bazaars, theaters and coffce houses. Camel riding, donlicy riding, elephant riding and the Oriental sports and pastimes furnisl an endless amount of amusement to the visitor, while in the theater may be seen the congress of Oriental dancing girls, including La Belle Rosa, Fatma, Fatima, Carmen and many others in their peculiar native dances.

\section{DREAMLAND.}

At the west end of the Midway is the blilding occupied by Dreamland, or the Mirror Maze. Behind mirrors is a large amount of fun for those who attempt to explore its recesses. No illusion on the Midway is more confusing and amusing.

\section{CINEOGRAPII.}

In this building, located at the north end of the west Mlidway, are 
The Pan-American Official Catalogue and Guide.

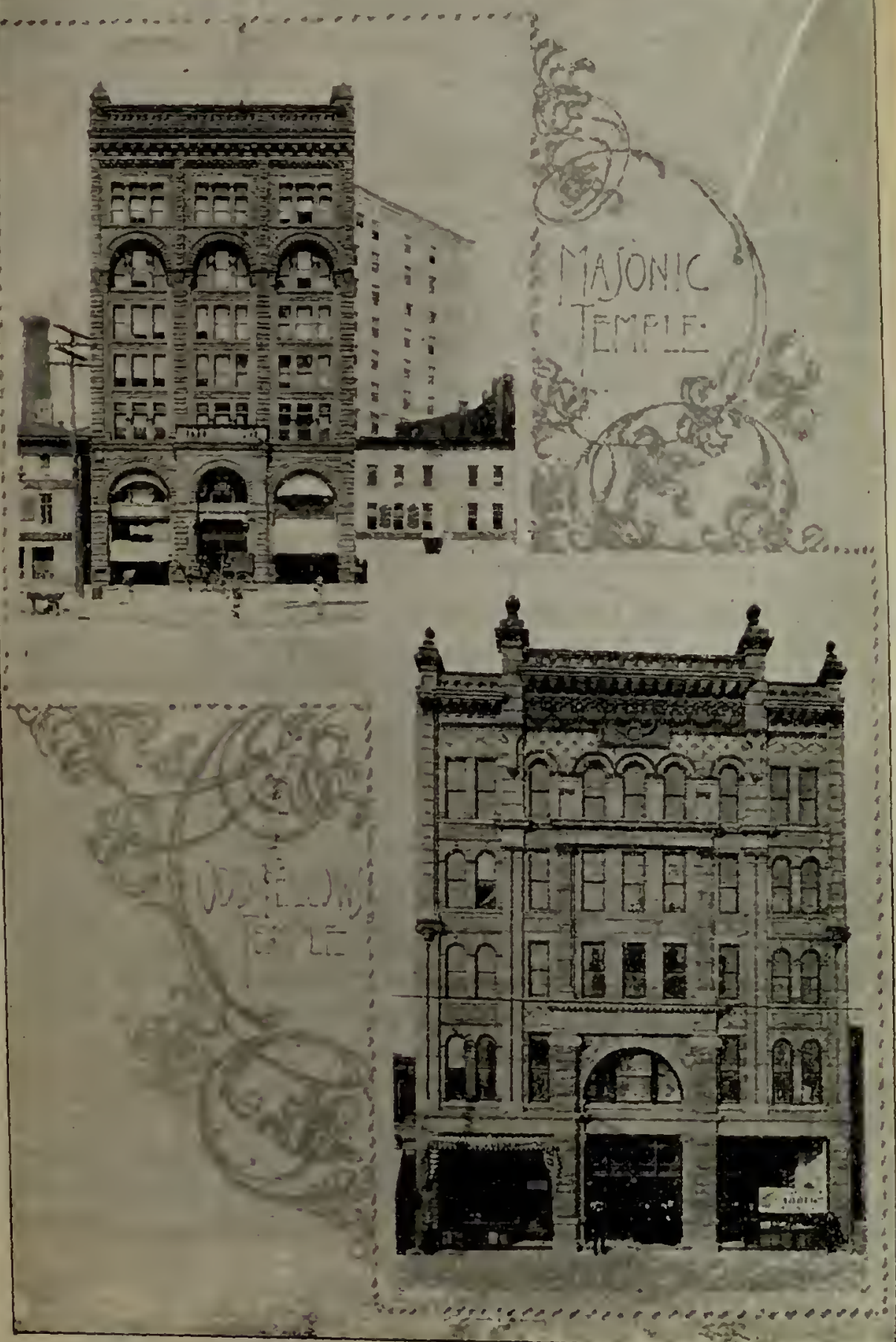


The Pan-American Uffioil Catalogue and Guide.

shown a collcction of moving pictures of various scenes in life, faithfully reproducing motions, etc., so that the pictures appear extremely realistic. The pictures are entirely of scenes of interest, and are a highly creditable colicction.

\section{MRS. McCREADY'S RESTAURANT.}

Here the visitor may procure foods of any description to satisfy "the inner man." A first-class restamrant in every particular and assured of a high-class patronage.

\section{WAR CYCLORAMA.}

Representing the Battles of Missionaly Ridge and Lookout Mountain. The visitor has presentcl before him the scenes of this great battlc of the Civil War. The proprietor's could scarcely have selected a more interesting and instructive picture for the occasion.

\section{THE CARDIFF GIANT.}

Here are exhibited the fossil remains of a prehistoric man. This curiosity was dug up near Cardiff, N. Y., in 1869, the remains being over ten feet in length and weighing nearly 3,000 pounds. The giant has caused consideralle of a scnsation and has been an object of interest to many of the most noted scientific men throughout the country.

\section{CORA BECKWITH.}

Visitors to this concession will have the opportunity of seeing this noted lady swimmer. In a tank erected in the center of the building, continnous exhibitions are given in which Miss Beckwith performs the many aquatic feats of swimming, diving, etc., which have already marle lier famois.

\section{WILD WATER SPORTS.}

Here a number of elks and other animals are exhibited. From platforms erected hich above a lake constructed in the center of the building, living elks dive into the water below, and perform other equally daring feats for which they have been especially trained.

A fcature of the exhibit is the "Wild Boar Chase," in which genuine Norwegian boars arc seen pursied by hounds and mounted hunters through the mountain passes, the chase terninating by the hoars, hounds and mounted hunters plunging into the lake.

\section{GYPSY CAMP.}

In this exhibit tlue visitor is introduced to a genuine gypsy camp. with all its emhellishments true to their manner of life. Fortunes are hele told that cannot fail to come true, and the opportunity is afforled 
The Pan-American Official Catalogue and Guide.

of purchasing the many various articles made by the gypsies and pert liar to their race.

In the theater is Princess Stellita with her troupe of Cynsy dancer: and Lola Cotton the phenomenal mind reader.

\section{BOSTOCK'S CHARIOTS.}

Similar in operation to a merry-go-round, although possessing man? new and distinct features, this concession cannot fail to do a rusbili? business. The amusement afforded is especially entertaining to people both old and young.

\section{JOHNSTOWN FLOOD.}

For this concession a large building has been constructed norti of the Bazar building. In it is presented a graphic illustration of the storm leading up to the breaking of the artificial lake and the awtu flood of the Conemaugh river which overwhelmed the city of Jobns. town, Pa., in 1889. This exhibition will interest all lovers of the artis tic and is indeed a phenomena of color effects. On the ground floor of the building, the management have provided parlors to be used as educational headquarters for teachers, etc.

\section{PHILIPPINE VILLAGE.}

This is the opportunity for all to learn just how a Filipino villagt looks. It contains representatives from all the races inhabiting the islands, ranging from cannibalism to the highest degree of civilization. The industries of the islands, cultivating with the water buffaloes, rope and cigaretos manufacturing, and the weaving of the beautiful pina sills are here seen. In the theater are given the native plays, and the great Bolo Sword dance, danced for the first time in this country.

\section{ALT NURNBERG.}

"Alt Nurnberg," the German Village of the Exposition, conveniently located at the corner of the Midway and the Mall, is one of the most picturesque spots to be found on the grounds. Its main features are the architectural reproductions of buildings in the famous old city of Nurnberg, and the idea is carried out in a most artistic manner. Among the many attractions to be found there are the Royal Bavarian Band of 48 pieces, under the direction of Herr Jacob Peuppus, Royal Bavarian Director of Music; Fraulein Antoine Stolle, with color reprocuctions of famous paintings; the Gebhard astronomical clock, the Koenigseer troupe of peasant singers and youlers, and Luchow's famous German restaurant.

INFANT INCLBATORS.

This exhibit is housed in the brick structure which is the next east 


\section{The Pan-American Official Catalogue and Guide.}

of the Service building. In it is a complete incubating plant where elevell piematurely born children are being reared. Many new and original devices are here illustrated, and not only in novelty but from an instructive point of view is the exhibit interesting.

\section{FAIR JAI'AN.}

Eutering the Japanese village, through the gatc of the Nikkil Temple, onc can casily imagine himself to be in Fair Japan. Native girls in native costumes serve the tea, and geisha girls entertain you with dancing. The buildiugs and decorations are strictly Japanese. A reproduction of a royal dwelling is shown and in the numorous bazaars and shops all sorts of trinkets are exhibited and sold as souvenirs. A free outdoor periolmance is giren at times and in the theater is given a strictly Japanese performance, by the native jugglers, dancers, etc.

\section{IDEAL PALACE.}

Opposite Venicc in Amcrica is the ldcal Palace. This in reality is an artist's studio wherc are illustrated many of the famous ar't mastcrpieces. Living subjects are used cutircly in illustrating the many pieces, the troupe consisting of some two dozen American and foreign models, selected from various studios. The diffcrent paintings are very faithfully 1 eproduced and for lovers of art, and others as well, this is certainly a treat.

\section{SCENIC RAILWAY AND AQUARAMA.}

Trains of cars glide up and down the Scenic Railway, upon which the visitor may ride and enjoy a wonderful variety of landscape views. Electrically illuminated tunnels are passed which are filled with beautiful scencry. The sensation of the ride can bc compared to that of coasting down hills in winter, without the element of danger to life and limis. The Aquarama consists of a canal over 1,100 feet long, winding throngh beantiful scenery, representing lakes, forests, etc., and terminating in the famous "Caves of Capric." Securely built boats carry the visitor safely along, the beautiful elcctrical effects adding realism to the scenes.

\section{THE ZANZIGS.}

Hcre are seen the famous palmists, whose reputation in this art is almost universal. One can scarcely conceive the marvelous accuracy which this celchrated troupe displays in character and life-reading, as shown by the lines of the hands. Many are dissatisfied with their present vocations in life and this attraction affords them an opportunity of ascertaining their mistakes, and starting anew in their chosen calling. 
The Pan-American Official Catalogue and Glide.

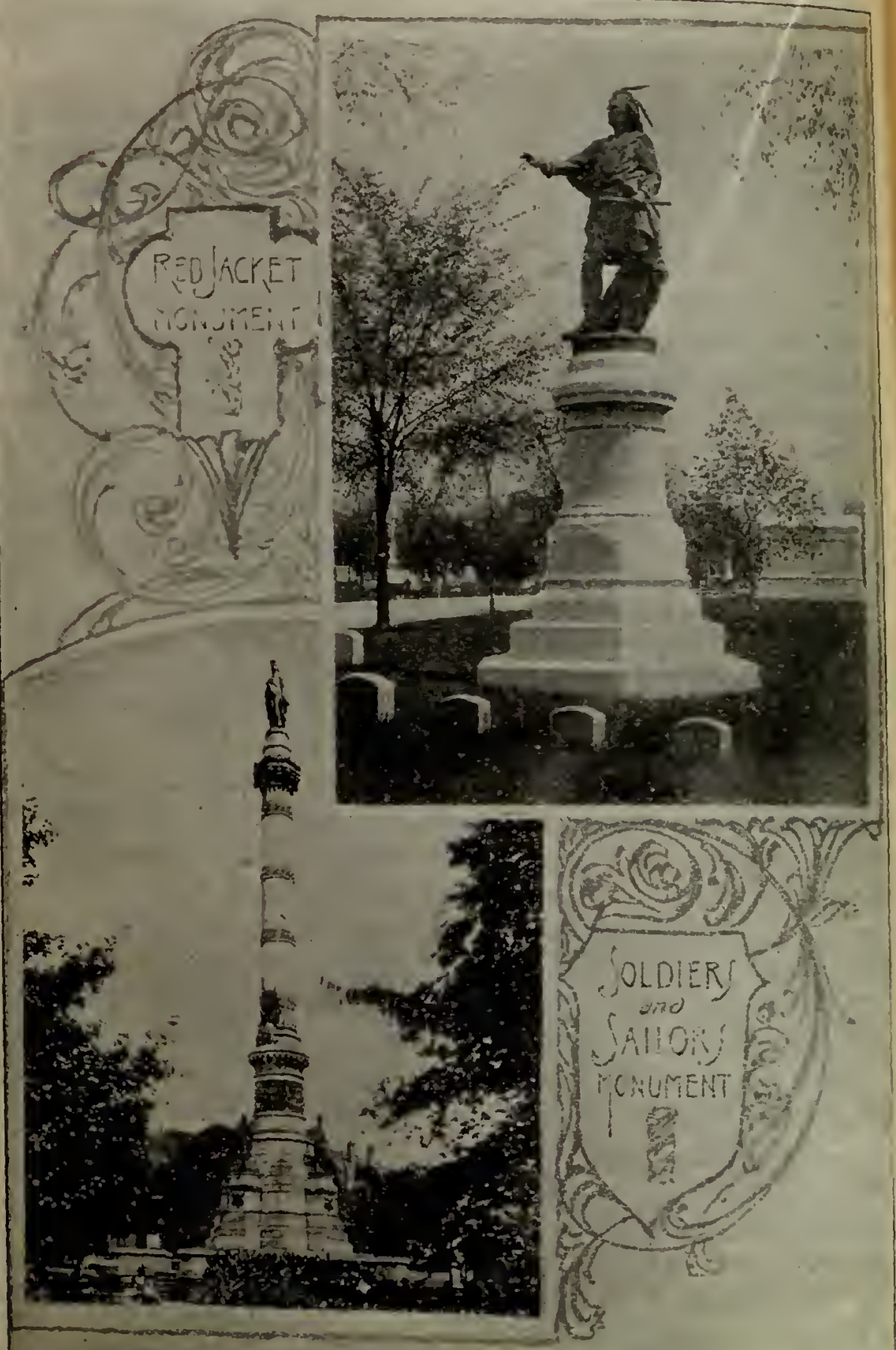


The Pan-A merican Official Catalogue and Guide.

\section{DAWSON CITY.}

A series of skillfully worked-out transformation scenes, assisted with elaborate electric scenic effects, depicting a trip to Dawson City and terminating in the awful destruction of that city as it occurred in January, 1901. Starting his trip through Weber Canon, Utah, the visitor arrives at Seattle and departing by steamer encounters an ocean storm. After his arrival at Skagway, crossing the White Pass and shooting the White Horse Rapids, the traveler arrives at Dawson City in the land of the Midnight Sun. So vivid are the scenes representing the conflagration, that one can almost inagine himself an eye-witness of the catastrophe.

\section{THE EVOLUTION OF MAN.}

Here the Darwinian theory of evolution is very completely illustrated. The sncessive stages of development by which the "genus homo" of the present day was evolved from its primaeval progenitors is show'n by numerous well-selected examples, from the lowest type of Simian development to the "missing link" or educated chimpanzee, Esau, who all but talks, and from the lowest savage to the polished gentlemell of today.

\section{BOSTOCK'S ANIMAL ARENA.}

Located just inside the Elmwood entrance, and west of the Horticulture building. This is one of the greatest amusement features of the Midway. The exhibit. presents one of the finest collections of trained wild animals ever before shown, more than 1,000 caged beasts appearing in the exhibit. Continuous performances are given in the eage erected in the center of the building, and the trained animals, birds and reptiles from every clime are made to do their trainers' bidding. The crowning feature is the challenge act of Capt. Bonavita, with 25 performing forest-bred lions.

\section{CHIQUITA.}

The next building south of the Animal Show is the home of Chiquita. This sprightly little midget was born on the Island of Cuba, a little over 31 years ago. Her height is but twenty-six inches, thongh she is proportionately developed and possesses a remarkably beautiful face. Her parlors, in which she receives visitors, are daintily furnished in keeping with the diminutive proportions of the mistress, who is a fluent conversationalist in seven different languages and, therefore, a most interesting hostess.

\section{VENICE IN AMERICA.}

This is a perfect rempica of the living city, with real palaces, shops 
The Pan-American Official Catalogue and Guide.

bridges and canals, gondolas and gondloliers. Visitors can ride in the gondolas and be steered through the windings of the palace-lived waterways, while the ear is charmed with sweet songs and the mustc of the mandolin or guitar.

\section{OSTRICH FARM.}

The ostrich farm consists of an enclosure of $2 \frac{1}{2}$ acres in which are shown about 75 ostriches, of all sizes from the chick to the full grovn bird. The nests of the birds, with eggs and feathers in the unfinished conditions are shown, and the process of raising the birds, producirg, curing and marketing the feathers is illustrated. From an instructive point of view the exhibit is assuredly interesting.

\section{JERUSALEM ON THE DAY OF THE CRUCIFIXION.}

This consists of a cyclorama representing the scencs, conditiors, \&c., in and about Jerusalem on the day Christ was crucified. The fane of this production is quite well known throughout the country, and will be of special interest to those religiously inclined, and a lesson to others.

\section{MINIATURE: RAILWAL.}

This is inceed the snallest operating railroad in the world. Passengers have the same seating comforts as on first-class trains and are given a trip possessed of many novelties.

\section{THE INDIAN CONGRESS.}

Located at the south cnd of the Midway, west of the Horticulture building, and near the Elmwood avenue entrance. Here are congregattd 700 Indians, representing 42 distinct tribes and living in their aboriginal and primitive state. Fifteen famous War Chiefs, Indian Rouga Riders, Indian Dances, Sports and Pastimes, Indian Museum, Ceremonial House; Winona, the Sioux maiden and champion rifle shot of the world; Indian Blanket, Basliet and Pottery makers; 500 Indians ir great realistic sham battle. No such lcsson in history can be gleaned from books as is here shown by "Native Americans"-long-haired painted savages in all their barbaric splendor.

\section{THE CAPTIVE BALLOON.}

To the left of the entrance to the Stadium is the space allotted for the exhibit of the Captive Balloon. The balloon is 100 feet in diameter, made of silk and carries a comfortable car for the seating of those who desire to make the trip upwards. It is operated by machinery and ascends to a height of 1,000 feet, remaining up 15 minutes, affording a magnificent view of the grounds and adjacent country. 


\section{Inscriptions of the Exposition.}

Upon the pancls of the promment buillings are the following inseriptions from the pen of Richard Watson Gikler, editor of the Century :

\author{
INSCRHTIONS FOR THE TROIY- \\ L.Alid.
}

Panel I-Iere, by the great waters of the North, are brought together the peoples of the two Americas, in expositlon of their resonrces. Industries, products, luventions, arts and hoas.

Panel II-That the century now begun may mite in the bonds of peace, knowledge, good will, friendship. and noble emulation all the dwellers on the continents and islands of the New world.

\section{IXSCIIPTIONS FOR THE STADIUM.}

Panel I-Not ignoble are the days of peace, not without combure and laniched victories.

Panel II-He who fails bravely has not truly falled, but is himself ilso a couguerol:

Panel III-TTho slums the dust and sweat of the contest on his birw falls not the cool shade of the olive.

\section{INSCRIPTIONS FOR THI: GREAT PY-} LONS OI THE IBIIDGI.

On the Pylons are statues of Cournge, laberty, Tolemuce. Truth. Henevolence, Patriotism, Ifospitality and Justice.

Panel I-The spirit of adventure is the maker of commonwealths.

Panel II-Ireedom is but the first les. son In self-goverument.

Panel III-Rellgious tolerance a safeguard of civil liberty.

I'anel IV-A free state exists oniy in the virtue of the citizen.

Panel V-Tho glves wisely builds manhond and the state-who gives himself gives best.

Panel V'I-To love one's conntry above all others is not to despise all others.

Panel VII-The brotherhood of manthe ferloration of nations-the pence of
the world.
Panel VIII-Petween nation and nation as betweon man and mall, lives the one law of right.

\section{DEDICATORI INSCHII'TONS.}

Panel J-Wo the ancient races of Atheria, for whom the New World was the lld, that their love of freedom and of mature, lheir batrly collage, their monmments, ats, legends and strange sulge may not perish from the eartb.

I'anel il-To the explorers and pioneers who blazed the westwarl path of civilizalion, to the soldiers and sailors who forght for fleedom and tor peace, and to the rivic heroes who saved a priceless heritage.

Pancl III-To the great inventors and ris r-sceing projectors, to the engineers. mantufofurers, agricilluralisis and merchants who have diveloped the resolnees of the New Worm, and multplied the homes of reomen.

l'anel IV-To those who in the deadly mine. on stormy seas, in the tierce bleath of the furnace and in all perilous places are working canselessly to bring to their fellow men comfort, sustenance and the
grace of life.

Panel V-To the scholars and laborious investigators who, in the old World and the New, guard the lamp of knowlalge aud, century by rentury, Inerease the safety of life, enlighten the mind and enlarge the splrit of man.

Panel VI-To those painters, sculptors and architects, frilers of tales. poets. and crentors of music, to those actors and musicians who in the New Wolld have cherished and increased the love of beauty.

Panel VII-To the prophrts and hejoes. to the mighty poets and divine altists. and to all the lighthearers of the ancint world who insplyed our forefathres and shall lead and enlighten our
children's children.

Janel VIIl-To the statesmen, philoso. plices, teachers and preachers and to all those who, in the New llorld, have up. held the ideals of liberty and justice, and have been falthful to the things that are eterual. 
The Pan-American Official Catalogue and Guide.

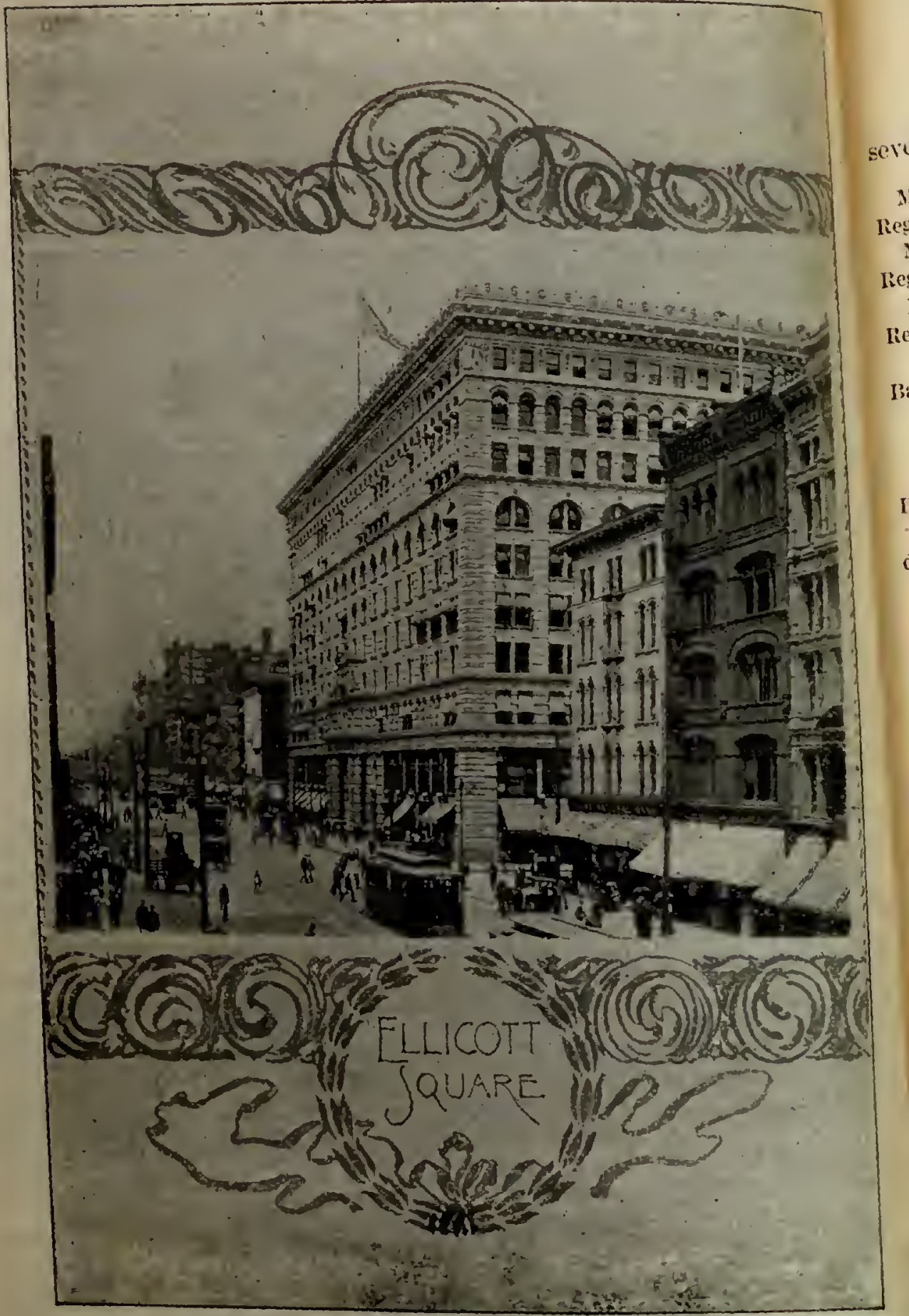


The Pan-American Official Catalogue and Guide.

\section{Music at the Exposition.}

Following is a list of the bonds that will furnish the music from the several band stands erected about the Plaza and the Esplanade:

ILay 1st to July $29 t h-$ Seventy-fourtl liegt. Iand.

Nay 1st to July agth-Sixty:fifth Iiegt. Iband.

May 6 th to June 1st-Seventy-first liegt. Band.

June : id to June Sth-Thirteenth liegt. Fand of llamilton.

June 10th to July 6th-Sousa's Isand. July sth to Aug. 4th-ligin liand.

July 29 th to Aug. 2uth-Scinta's Band.

July 29 th to Aug. 25th-Carlisle Indian liand.

Aug. 5th to Aug. 11th-Ithaca Band. Aug. 5th to Aug. 25th-I'hinney's Band.

Aug. 12th to Sept. Sth-Iand's Orchestra.

Aug. 26th to Sept. 1st-Forty-eighth Ilighlanders.
Aug. 26ith to Ang. 31st-Robertson's Band of Albany.

Sept. 2d to Sept. Sth-Kirk's liand.

Sept. 2 d to Sept. 15th-Salem Cadet Band.

Sept. 9 th to Oet, 6th-Irooke's Rand.

Sept. 1 fith to Sept. 21 st-Nineteenth liegt. liand.

Sept. 16th to Sept. 20th-Boston Ladies* liand.

Sept. 23d to Sept. 29)th-Detroit Concert Band.

Oct. Tth to Oct. 20th-Weber's Iiand.

Oct. 7 th to Oct. 20 th-Victor Herbert's Orchestra.

Oct. Tth to Oct. 20th-Innes' Isand.

Four Days-Newsboys Pand of Grand Iiapids.

Porto Rlcan String Band-Two months.

\section{PAN=AMERICAN ORGAN RECITALS.}

A unique and interesting feature of the Exposition will be the series of free organ recitals to be given daily in the Temple of Music. In connection with the stately structure devoted to the divine art, the idea early suggested itself to arrange for the erection of a great organ and to secure the services of distinguished organists who would effectively interpret the standard works composed for this instrument. In arranging these recitals, it has been the aim to have as many sections and important cities in the United States and Canada represented by their leading organists, as possible. The success attained in securing such artists has been extremely gratifying. They have shown a most encouraging spirit of good will towards the enterprise, and the only regret felt by the Exposition is that all who were willing to contribute their services in this cause could not be given engagements. As it is, however, about seventy-five organists (many of international reputation, and representing nearly every portion of this country and Canada), will be heard. 
The Pan-American Official Catalogue and Guide.

\section{ORGAN MUSIC AT THE EXPOSITION.}

The list of nimes of organists and dates follows:

May 1-19-I. V. Flagler, Auburn, N. Y.; C. P. Garratt, Hamilton, Ont, N. H. Allen, Hartford, Conn.; Wenham Smith, Newarl N. J.; Gerritt Smith, New York City.

20-22-Frederic Archer, Pittslurg, Pa. 23-25-IV. E. Fairclough, Toronto, Canada. 28-30-W. C. Hammond, Holyolie, Mass. 31- 1-W. P. Stanley, Brooklyn, N. Y.

June 2- 6-H. J. Stewart, San Francisco, Cal.

7- S-Russell K. Miller, Philadelphia, Pa.

9-12-Richard T. Percy, New York City.

13-16-J. Frank Donahoe, Boston, Mass.

17-19-E. Russell Sanborn, Boston, Mass.

20-22-Gustave Frese, Louisville, Ky.

23-25-Charles E. Clemens, Cleveland, O.

26-27-Henry Houseley, Denver, Col.

28-30-Harrison M. Wild, Chicago, Ill.

July 1- 2-Albert Jordan, Brantford, Canada.

3- 6-Louis Falk, Chicago, Ill.

7- 8-F. W. Raisberg, New York, N. Y.

9-11-Archer Gibson, Baltimore, Md.

12-14-William Reed, Quebec, Canada.

15-17-Frank H. Simms, New Orleans, La.

18-20-Francis L. York, Detroit, Mich.

21-23-J. D. Dussault, Montreal, Canada. -

24-25-S. D. Cushing, Toledo, O.

26-28-Mrs. Mary C. Fisher, Rochester, N. Y.

29 -George B. Carter, Delaware, O.

$30-$ W. H. Hewlett, Lonclon, Ont.

31 -Ferdinand Dunliley, Ashville, N. C.

Aug. 1- 3-Hamlin H. Hunt, Minneapolis, Minn.

4- 6-Charles Galloway, St. Louis, Mo.

7- 8-A. Ray Tyler, Brooklyn, N. Y.

9 - Wm. C. Schwartz, Philadelphia, Pa.

10 -Benjamin J. Lang, Boston, Mass.

12-14-Summer Salter, Ithaca, N. Y.

15-16-R. H. H. Clarke, Meriden, Conn.

17 -Mrs. P. V. M. Raymond, Lincoln, Neb.

18.20-W. S. Sterling, Cincinnati, O. 


\section{The Pan-tmerican Official Calalogue and Guide.}

Aug. 21-22-Miss Emma L. Maynard, Gary, S. D.

23-25-Arthur Bernier, Quehec, Canala.

27-28-Walter Heaton, Reading, Pa.

29-31-Henry Gordon Thunder, Philadelphia, Pa.

Sept. 2- 4-Gaston M. Dethier, New York City.

6. 8-Everett E. Truette, Boston, Mass.

9 -Harry L. Vibbard, Syracuse, N. Y.

10-11-Samuel P. Warren, New York City.

12-13-Miss Gertrude Sans-Souci, St. Paul, Minn.

14 - Harry J. Zehm, Harrisburg, Pa.

18-19-Thomas Radcliffe, Salt Iake City, Utah.

$20-$ Henly B. Vincent, Erie, Pa.

21-22-Herve D. Wilkins, Rochester, N. Y.

23 -C. A. Stein, Troy, N. Y.

24-25-J. B. Tipton, Albany, N. Y.

26-27-R. H. Woodman, Brooklyn, N. Y.

29-30-Miss Fannie M. Spencer, New York City.

Oct. 1 -John P. Lawrence, Washington, D. C.

2- 3-W. H. Donley, Indianapolis, Ind.

4- 6-Harry B. Jepson, New Haven, Conn.

7- 8-Miss Ione B. Riddell, Cincinnati, $O$.

10-12-William C. Carl, New York City.

13-16-Clarence Eddy, New York City.

17-1S-Harry Rowe Shelley, New York City.

21-23-N. J. Corey, Detroit, Mich.

27-:.9-William B. Colson, Cleveland, 0.

BUFFALO ORGANISTS-William .J. Gomph, official organist; An drew T. Webster, Will S. Jarrett, Henry S. Hendy, Seth C. Clark, Miss Mary McConnell and Ulysses Thomas. 
The Pan-American Official Catalogue and Gride.

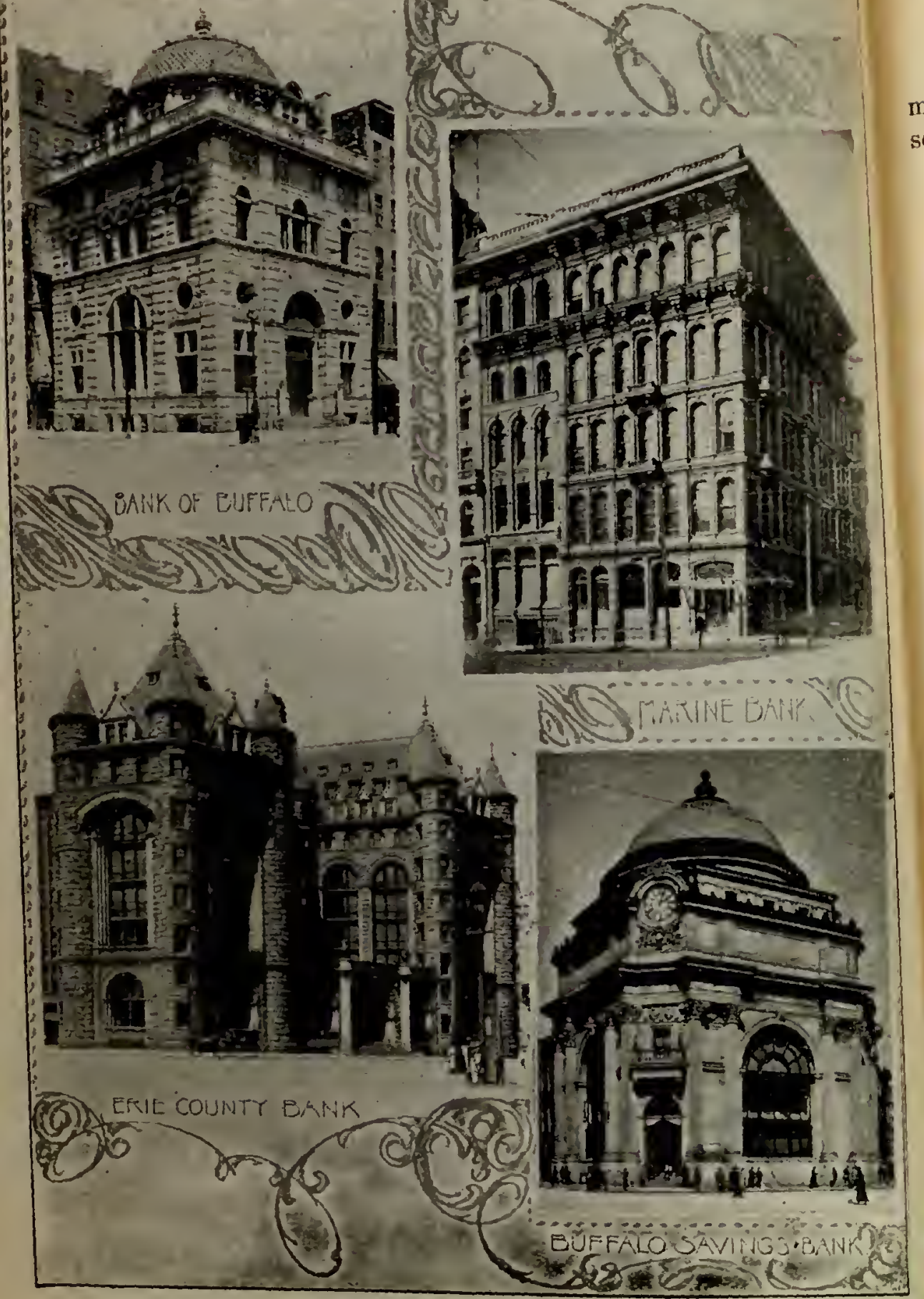


The Pan-A merican Official Catalogue and Guide.

\section{Sport Days.}

There will be a continuous carnival throughout the summer in the magnificent Stadium of the Pan-American Exposition. Following is the schedule of events:

Friday, May 17th-Cornell-University of Michigan Baseball Game. Saturday, May 18th-Erie County Track and Field Games.

Friday, May 24th-New York State Interscholastic Track Games. Saturday, May 25th-New York State Interscholastic Track Games. Friday, May 31st-Pan-American Intercollegiate Track Games. Saturday, June 1st-Pan-American Intercollegiate Track Games. Monday, June 3d to 7th-School Boy Military Tournament. Saturday, June Sth-Cornell-Carlisle Baseball Game. Thursday, June 13th-A. A. U. Championships.

Friday, June 14th-A. A. U. Championships.

Saturday, June 15th-A. A. U. Championships.

Monday, Jume 17th-A. A. U. Basketball Championslips.

Tuesday, June 18th-A. A. U. Basketball Championslips.

Saturday, June 22d-Western New York Track Meet.

Monday, June 24th-Canoe Meet.

Tuesday, June 25th-Canoe Meet.

Thurslay, June 27th-Volksfest (German Singing Societies).

Friday, June 2Sth-Scottish Games.

Saturday, June 29th-Scottish Games.

Monday, July 1st-Canadian-American Lacrosse Championships. Tuesday, July 2d-Canadian-American Lacrosse Championships. Wednesday, July 3d-Canadian-American Lacrosse Championships. Thursday, July 4th-All-round A. A. U. Championship and Handicap events; Marathon Race.

Saturday, July 6th-Exhibition by German Y. M. C. A. Ifonday, July Sth to Saturday, July 18th-Water Sports. Wednesday, July 10th-Interscholastic Basketball.

Thursday, July 11th-Interscholastic Basketball.

Friday, July 12th-National Interscholastic Track and Field. Saturday, July 13 th - National Interscholastic Track and Field. Monday, July 15 th to 20 th-Shooting Meet.

Tuesday, July 22d-National Y. M. C. A. Track and Field Games. Weduesday, July 24 th-National Y. M. C. A. Track and Field Games. Friday, July 26th-Metropolitan Meet A. A. U. Saturday, July 27th-Metropolitan Meet A. A. U. 
The Pan-American Official Calalogue and Guide.

Monday, August 5th-Bicycle Meet and National Amateur Char pionships.

Tuesday, August 6th-Bicycle Meet and National Amateur Char pionships.

Wednesday, August 7 th-Bicycle Meet.

Thursday, August Sth-Bicycle Meet.

Friday, August 9th-Bicycle Meet.

Saturday, August 10th-Bicycle Meet.

Monday, August 12th-Bicycle Meet.

Tuesday, August 13th-Bicycle Meet.

Wednesday, August 14th-Bicycle Meet.

Thursday, August 15th-Bicycle Meet.

Friday, August 16th-Bicycle Meet.

Saturday, August 17th-Bicycle Meet.

Thursday, August 22d-Firemen's Tournament.

Friday, August 23d-Firemen's Tournament.

Saturday, August 24 th-A. A. U. Gymnastics.

Wednesday, August 28th-l rish Sports.

Thursday, August 29th-Irish Sports.

Friday, August 30th-Irish Sports.

Saturday. August 31st-Irish Sports.

Monday, Sept. $2 d-A s s o c i a t i o n$ Football.

Tuesrlay, Sept. 3d-Association Football.

Wednesday, Sept. 4th-Association Football.

Thursday, Sept. 5th-Association Football.

Friday, Sept. 6th-Pan-American World's Championships, Cros Country Run.

Saturday, Sept. 7th-Pan-American Torld's Championships.

Monday, Sept. 9th-Cattle Show.

Tuesday, Sept. 10th-Cattle Show.

Wednesday, Sept. 11th-Cattle Show.

Friday, Sept. 13th-Cattle Show.

Saturday, Sept. 14th-Cattle Show.

Monday, Sept. 16th to 21st-Automobile Week.

Saturday, Sept. 28th-Columbia-U. of B. Football Game.

Saturday, Oct. 5th-U. of B.-Lehigh Foothall Game.

Saturday, Oct. 12th-U. of B.-Brown Football Game.

Saturday, Oct. 19th-Cornell-Carlisle Football Game.

Wednesday, Oct. 23d-Wesleyan-U. of B. Football Game. 
The Pan-American Official Catalogue and Guide.

\section{Special Days.}

May 1-Opening Day.

20-Dedication Day.

6-Hotel Men's Day.

12-Coal Men's Day.

13-President's Day.

14-Flag Day.

17-New England Day. Bunker Hill Day.

18-Wells College Day.

19-A. O. U. W. Day.

20-Comecticut Day.

21-Rochester Day.

24-29-Saengerfest.

26 -Odd Fellows' Day.

27-Odd Fellows' Day. Volksilest (evening).

28-Cincinnati Day.

29-Philadelphia Day.

July 1-Dominion Day.

2-Missouri Day; Dedication of Lonisiana Purclase Bldg. Wellesley College Day.

3-Dedication Illinois State building.

4-1ndependence Day.

5-New York Liederkranz Day. New York State Association of 'Teachers.

6-Educators' Day.

10-Maryland Day.

11-Commercial 'Travelers' bily.

16-Chautauqua Day.

18-Ohio Day.

19-Eagle Day.

23-C. M. B. A. Day.

24-Knights of Columbus

Day. Utalı Day.

25-Scandinavian Day.

Porto Rico Day.

27-Wisconsin Day.

30-National Commissioners'

Day.

31-Eliks' Day.
Aug. 1-Mystic Shriners' Day.

6-Cornell-I thaca Day.

7-Maccabee Day.

8 -Vermont Day.

10-Missouri Day.

12-Cuba Day.

14--Virginia Day. Insurance Dily.

15-Red Men's Day.

20-Michigan Day.

21-Louisiana Day.

22-Electrical Day.

23-Virginia Day.

26-Municipal Day.

Sept. 2-Iabor Day.

; - District of Colmubia Day.

4-International Press Enion of Wonnen.

6-National Association of Stutionary Engineers' Day.

9-Spanish-American War Veterans' Day.

10-Rhode Island Day.

11-Architects' and Builders' Hay.

12-Polish Day.

14-Vassar College Day.

16-Mexican Day.

17-Grand Army of the Republic Das.

18-New York State Day.

19-Welsh Day.

20 -St. Catharines Day.

21-Nurses' Associated Alummae Day.

25-Oregon Day.

26-Cleveland Day.

30-Stewards' Day.

Oct. 8-Brooklyn Day.

9-New York Federation of Women's Clubs.

10-National Grange Day.

11-Atlantic City Day.

12-International Sunshine Day. 
The Pan-A merican Official Catalogue and Gurde.

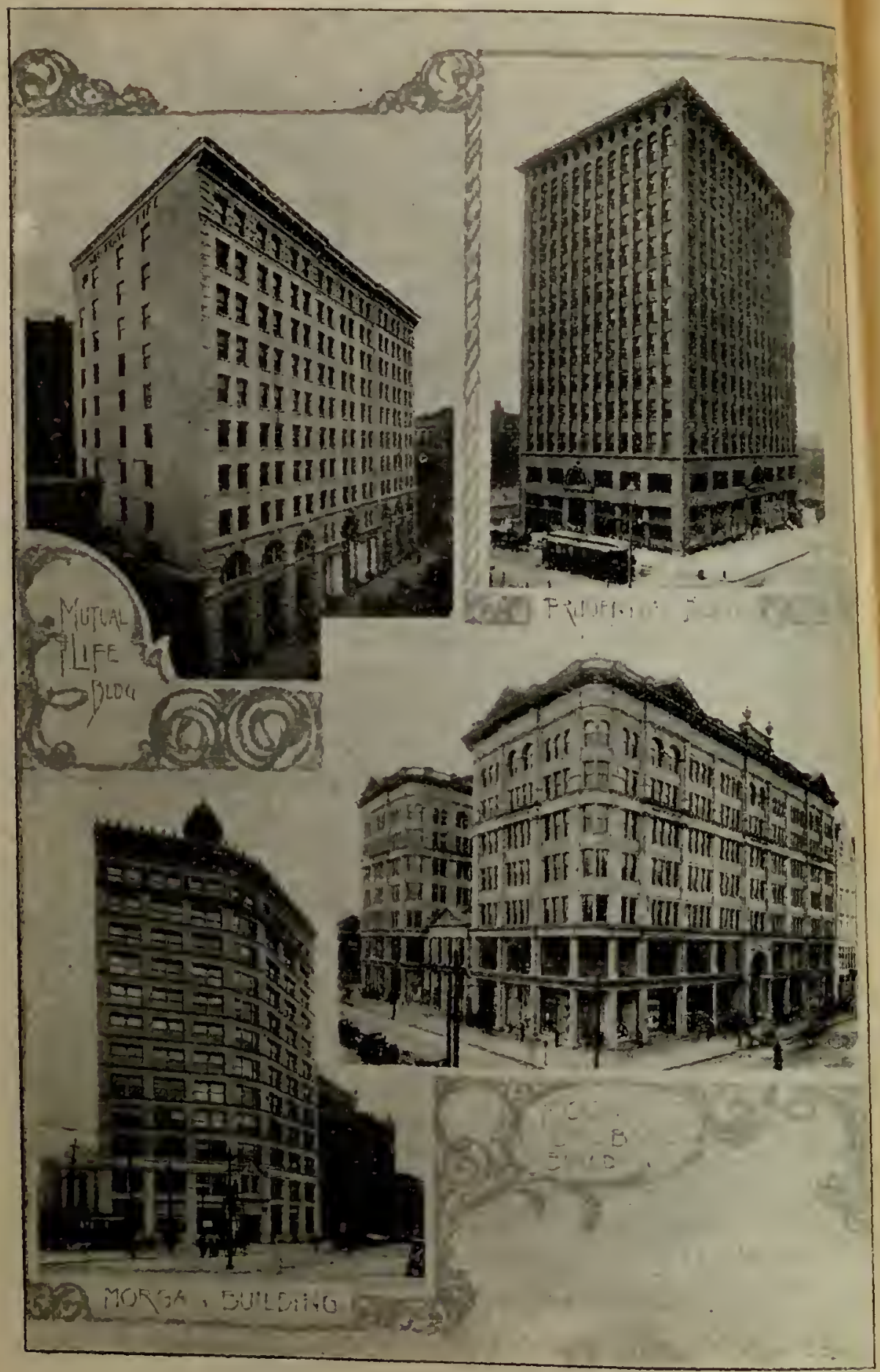


The Pan-American Official Catalogue and Guide.

\section{Conventions to be Held in Buffalo.}

The following conventions will be held in Buffalo during the present year:

May 9 -New York State Medical Association (Fourth District).

15 -National Tile, Grate and Mantle Association.

22 -Daughters of Veterans, New York State Department.

23-24-National Civic Federation.

23-25-Alpha Delta Phi.

....-Reunion Smith Family of Ohio, Vermont and Connecticut.

June 1 -Gamma Signa Fraternity.

4- 6-American Foundrymen's Association.

4- 6-United States Brewers' Association.

4- 8-State Pharmaceutical Association.

4- 8- Minnesota State Editorial Association.

8-11-Western Dancing Teacher's' Association.

10 - National Association of Circulating Managers.

10 -American Institute of Electrical Engineers.

10 - Associated Ohio Dailies.

10-13-National Educational Association.

10-13 - State Editorial Association.

10-13-Oregon Press Association.

10-20-Ancient Order United Workmen, Supreme Lodge.

12 - County Superintendents of the Poor, State Convention.

15 -National Prize Turnfest of the North American Turnerbund.

15 -National Association of Turn Teachers.

18-20-Junior Order United American Mechanics.

20 -New York State Bankers' Association.

24-25-American Canoe Association.

24-29-North American Saengerbund.

24-29-National Association of Elocutionists.

27-29-Manual Training Teachers' Association.

28-29-Kappa Alpha Fraternity.

....-Women's Literary and Educational Organizations of Western New York.

....-Special Exhibit of the New York State Horticultural Societies.

.....-Tile Layers' Union of America.

....-National Stove Lining Association.

.....-West Virginia Editorial Association. 
The Pan-American Offial Catalogue and Guide.

June ....-Special Meeting of the Commercial Teachers' Federation.

July 1-3-State Teachers' Association.

2 - Metropolitan Association of the Amateur Athletic. Union.

2. 3-Theta Delta Chi.

4. 6-German Catholic Union.

4. 6-Eastern Puzzlers' League.

8-13-National Association of Colored Women.

9-13-Commercial Travelers' Conclave Week.

9-13-Retall Clerks' National Protective Association.

9 -Sons of St. George, Grand Lodge.

12-20-Congress of Indlan Educators.

15 - State League of Co-operative Savings and Loan Assocle. tions.

17-31-Pan-American Bible Study Congress.

18-21-International Convention Anti-Cigarette League.

20 - National Association of Photo-Engravers.

23-25-Grand Chapter Signa Chi Fraternity.

25 - International Jewelry Workers' Association.

25-28-Young People's Alliance, General Convention.

25-30-Great Lakes' Yachting Association.

.....-Associated Bill Posters of the United States and Canada.

....-Electrical Contractors' Association, State.

Aug. 1. 6-United Supreme Council of the Ancient Arabic Order Sco. tish Rite Masons (colored).

2 -Improved Grand Councll Ancient Arabic Order Nobles of the Mystic Shrine.

3 - National Grand Court of the Daughters of Sphinx (colored).

5 -General Grand Councll R. \& S. M. of the United States and Canada.

5- 10-Society of American Florists and Ornamental Horticulturists.

5.17-National Cycling Association, Annual Racing Meet.

6 -National Federation of Labor (colored).

12-14-National League of Improvement Associations.

12-15-Great Councll, Improved Order of Red Men.

12-17 - League of American Wheelmen.

15-20-National Shorthand Reporters' Association.

19-20-Philatelic Sons of America.

19-25-United Assoclation of Journeymen Plumbers, Gas and Steamfitters of the United States and Canada. 
The Pan-American Official Catalogue and Guide.

Aug. 20 -Spanish-American War Veterans, State.

20-24-State Firemen's Association.

22 -Reunion Survivors Engineers' Brigade, Army of the Potomac.

22-24-State Shorthand Reporters' Association.

24 - International Acetylene Gas Association.

26-28-American Philatelic Association.

....--National Firemen's Association.

....-National Dahlia Association.

....-National Haymakers' Association.

....-National Prohibitionists' Conference.

....-American Institute of Farmers' Institute Workers.

Sept. 1 -American Promological Society.

2. 5-International Brotherhood of Blacksmiths.

4 -Delivery Proprietors' National Association.

9.12-Hoo-Hoo National Concatenation.

10-14-Master Car and Locomotive Painters' Association.

16 -Shlrt, Shirtwaist and Laundry Workers' International Afsociation.

17-19-American Boller Manufacturers' Association.

17-19-New York State Assembly American Fraternal Insuranco Union.

17-20-American Public Health Association.

20 - State Side-Path Commissioners.

23 - Stereotypers' National Association.

24-26-American Electro-Therapeutic Association.

24-26-Patriotic Order Sons of America, National Camp.

25 -Spanish-American War Veterans, National Camp.

.....-United Typothetae of America.

....-International Council of Nurses.

....-Master Composition Roofers of the United States.

....-Empire Knights of Relief.

....-Roentgen Ray Soclety of the United States.

Oct. 1. 3-International Cremation Congress.

8-10-State Federation of Women's Clubs.

8-11-National Association of Retail Druggists.

14 - Knights of the Golden Eagle, Supreme Castle.

14 -National Hardware Association.

15 -New England Cotton Manufacturers' Association.

15-17-American Humane Association.

18-23-National Universalist Conference (biennial). 


\section{The Pan American Official Oatalogue and Guide.}

Sept. 21 -National Household Economic Association.

21-26 - State Synod of the Presbyterian Church.

....-Regular and Volunteer Army and Navy Association.

....-Beekeepers' Association of the United States.

....-Special Meeting of the State Dairymen's Association.

....-National Association of Dairy and Food Commissioners.

....-National Good Roads' Convention.

....-National Irrigation Congress.

....-American Leicester Breeders' Association.

....-American Oxford Down Association.

....-American Institute of Architects.

....-Railway Signaling Club.

....-Retall Furniture Association of the United States.

..-..-New York State Sabbath Association.

Nov, 12 -International Wood, Metal and WIre Lathers' Union.

\section{INDIAN MOUNDS.}

The mounds of the models of Mound Builder earthworks in the S. E. portion of the Pan-American Grounds are an unusual feature so far as Expositions are concerned. The large ringed mound is an example of several similar earthworks found in different parts of the Mound Builder territory. In Greenup Co., Ky., there is a ringed mound, the ring being $5 \mathrm{ft}$. high and $30 \mathrm{ft}$. across at the base. Within this ring is a ditch $25 \mathrm{ft}$. wide and $6 \mathrm{ft}$. deep. The ditch encloses a circular area $90 \mathrm{ft}$. in diameter In the center of which is a mound $40 \mathrm{ft}$. in diameter and $8 \mathrm{ft}$. high. There is a narrow gateway at one place in the ring.

The Marletta Mound, the most celebrated of the ringed mounds, is at Marietta, Ohio. The ring is an ellipse, 213 to 215 feet in diameter and 30 feet high. The chamber here represented was reproduced from the Report of Explorations by Prof. Wm. C. Mills of the Ohio State Univer. sity. The mound explored by Prof. Mills was only $11 \mathrm{ft}$. high and on adding to the height of the present mound it was found that the chamber would not support the weight of earth and it was necessary to place extra supports. The walls of the chamber have been covered with puddled clay and bark representing two methoda probably in use by the Mound Builders. 
The Pan-American Offoial Catalogue and Guide.

The Serpent Mound is reproduced from the original near Brush Creek, Adams Co., Ohio. The serpent is supposed to be swallowing an egg. In the original the body of the serpent is $700 \mathrm{ft}$. long or nearly $1000 \mathrm{ft}$. following the curves. The original is $5 \mathrm{ft}$. in height and $30 \mathrm{ft}$. wide at the base at the middle of the body. The small oval mound is $4 \mathrm{ft}$. in height and formerly contained a stone altar in the center. The original mound is located on a hill and has been arranged about the oval mound so as to conform to its outline and to leave a small platform 10 ft. wide. The significance of the small triangular mounds upon either side of the serpent's head is not known.

The Eagle Mound represents a common type of mound builder earthworks. The orlginal mound, of which this is a reproduction, measures 30 feet from tip to tip of the wings.

\section{ALASKA BUILDING.}

In the space allotted to state and foreign buildings, and south of the Forestry building, is the unlque structure erected by the Territory of Alaska. It is a bullding $75 \times 50 \mathrm{ft}$. and constructed entirely of rough logs. Besides the exhibits in the Exposition buildings, a large number of extremely interesting exhibits may be found here.

\section{SIDE TRIPS FROM BUFFALO.}

Buffalo is fortunate in her immediate surroundings and when tho visitor to the Exposition shall have satisfied himself with sightsecing within the grounds, he will find much to delight him in and near the city or within a few hours' ride in any direction. The entire region about Buffalo is rich in its variety of natural scenery, and some of the most famous resorts in the world are near at hand. Popular summer places close by the city, to be reached by steamers upon Lake Erle and the Niagara River, are: Woodlawn Beach, on the American shore, south of the city; Crystal Beach, on the Canadian shore, an hour's ride from Buffalo; and Grand Island, with its many groves and summer botels, on Nlagara River, just below the city.

\section{CHAUTAUQUA.}

Scarcely less famous than the Falls of Niagara, is the Summer School at Chautauqua. This great educational center was many years ago founded by Bishop John $H$. Vincent of the Methodist Church, upon Chautauqua Isake, among the picturesque hills of Chautruqua county, 
The Pan-A merican Official Catalogue and Guide.

800 feet above Lake Erie. The Assembly grounds have come to be the permanent abode of a considerable number of people and during six weeks of the summer season many of the most eminent men and women in educational and reform work of all kinds are to be heard in the great amphitheater. Students by thousands from all parts of the country; as well as from foreign lands, gather here to enjoy the bountiful feasts of learning amid scenery of rare beauty and attractiveness. From Buttalo one may reach Mayville at the head of the lake by the Western New York \& Pennsylvania Railroad, or Jamestown at the foot, and Lakewood between these points, via the Erie Railroad. The Chautauqua Steamboat Company operates elght steamers on the lake and the round trip is a most delightful sail of about 40 miles. The train and boat service is such that one may leave Buffalo in the morning returning in the evening, and spend half the day on the lake. Near the foot of the lake is Celeron, the Coney Island for that part of the State, where a vast plant has been established for the amusement and entertainment of the public. The:e are numerous summer resorts along the shores, with fine hotels, and at tendant fleets of small steamers and other craft-Point Chautauqua, Greenhurst, Lakewood, Bemus Point and others.

\section{THE THOUSAND ISLANDS.}

The Thousand Islands attract numberless visitors every season. These rocky isles are surrounded by deep-water channels and are crowned with a thick growth of cedars and other trees. The fresh, ex. hilarating atmosphere is ever inviting to the cottager and the camper, and summer homes, from the board shack or tent to the palatial villa, aro to be seen upon these island shores. An excursion among these isl. ands is full of interest, even to the hurried traveler. The region is well supplied with good hotels, and the railroad and steamboat accommoda. tions are such as to meet all demands. One may have a choice of several routes from Buffalo. He may go by the New York Central to Charlotte and thence by a steamer of the Lake Ontario \& Bay of Quinte Steamboat Company, or the Lake Ontario \& St. Lawrence River Day Line, through Lake Ontario, or he may take a morning or evening train on the New York Central to Clayton, where boat connections are made. Another popular route is by way of Toronto, on the Niagara Navigation Com. pany's steamers to Toronto, and thence by the Richelieu \& Ontario Navigation Company's line via the Bay of Quinte. 
The Pan-American Offcial Catalogue and Guide.

\section{MUSKOKA LAKES.}

The Muskoka Lake region of Canada has become popular with Americans in recent years. Muskoka wharf is only eight hours' ride by rail from Buffalo by way of Hamilton and Toronto. The Toronto, Hamilton \& Buffalo, Canadian Pacific and Grand Trunk all go to Toronto, and the Grand Trunk to Muskoka Wharf. Another pleasant route is by the New York Central to Lewiston, or Michigan Central to Niagara-on-theLake and by steamer to Toronto, and thence by rail to Muskoka. The three lakes, Muskoka, Rosseau and Joseph, have a shore line of 1,000 miles, and the climate is not only healthful but most exhilarating and delightful throughout the torrid season. The region is wild and romantic, and the thousands of campers who frequent the shores and islands of these lakes during the hot months have hearty welcome for all who come to foin them. The hotels are run on a family plan, and whoever loves boating and fishing will find abundant recreation here.

\section{TRIPS WEST BY WATER.}

The trip from Buffalo to Duluth and other lake points may be made upon the swift passenger steamers that rival in their beauty and equipment the finest steamships in the world. No journey is more refreshing than a ride through Lakes Erie, Huron and Superior in mid-summer upon boats of the Northern Steamship Company, Anchor or Lackawanna Lines, or through the wild and majestic scenery of Georgian Bay, from Collingwood, Parry Sound and other points. The Canadian Pacific Railway offers an attractive trip by rail from Buffalo by way of Toronto to Owen Sound, thence by boat through Georgian Bay and the Manitou Islands, the Sault Ste. Marie Canal and Lake Superior to Fort William, where connections are made with the main line. In the vicinity of Detroit are Put-in-Bay, Mt. Clemens, Grosse Isle and Belle Isle Park, with numerous summer homes and public resorts along the St. Clair River. For a short trip one may take the ride from Buffalo to Cleveland in one of the sereral floating palaces of the Cleveland \& Buffalo Transit Company, or to Erie, Pa., by the Erie \& Buffalo Line. By steamer the City of Erie is four hours away; Cleveland, nine hours; Detroit, eighteen hours; Put-in-Bay, elghteen hours; Mackinaw, thirty-flve hours; Sault Ste. Marie, forty-two hours; Duluth, fifty-nine hours. 


\section{The Pan-American Ofioial Catalogue and Guide.}

\section{BRIEF HISTORY OF THE CITY OF BUFFALO.}

In 1792 , the first permanent settlement was made at the mouth Buffalo Creek and for a while did not grow very rapidly. In $1805, T$ Holland Land Company, which owned a considerable portion of the the sent Joseph Ellicott to survey its property and lay it out in lots ay streets. The hamlet was called New Amsterdam, but the name of Bi falo, which it took from the creek, was preferred by the people and wh soon adopted by the Company. Joseph Ellicott was the real founder of the City and it was due to his foresight and energy that the little ser tlement in the wilderness grew and prospered.

Buffalo and its vicinity was the scene of several hard fought bal tles in the War of 1812. The village was burned by the British and Indians in 1813 and the inhabitants bad to flee in all directions to sarp their lives. As soon as the war was over, the village began to build us again and was soon in a flourishing condition.

The completion of the Erie Canal, in 1825, gave an added stimulus to its growth, so that in 1832 Buffalo was incorporated as a City witha population of over 10,000 . After the completion of the canal, Buffalo grew steadily and rapidly.

The lake passenger business became a great feature and many fing vessels were engaged in the business. With the advent of the first rall. road, this business began to decline and as their construction became general almost passed away.

When the War of the Rebellion broke out, Buffalo's citizens nobls performed their duty to the Republic and its regiments won an enviable record. While the war lasted, the great amount of produce, moved at a high cost of transportation, sustained commercial activity. After the War, came the hard times of the seventies, but Butfalo's splendid sit. uation as a gateway to the West. soon brought a new and lasting era of prosperity, which the population of 400,000 at the present writing at. tests.

\section{THE ELECTRIC POWER.}

A large portion of the electricity that will be used at the Exposition will come from Niagara Falls. This transmission of power means \& great deal for the future of Buffalo, as its use is practically unlimited. At first it was thought that power could not be transmitted such a dis. tance and many famous electricians believed that the power would never be available for commercial. purposes. The street railway lines are partly operated by electricity generated at Niagara Falls. This power will, of course, be cheaper than coal or else its promoters could not expect to compete with coal as a source of generating power. As 


\section{The Pan-American Official Catalogue and Guide.}

it will necessarily dispense with the greater part of the labor now necessary in handling the product of the mines, Buffalo manufacturers will be enabled to undersell their competitors and thus help to bring more business to Buffalo.

\section{PARKS.}

Buffalo's splendid system of parks with its connecting boulevards and parkways nearly encircles the city. On a high bluff, near the confluence of Lake Erie and Niagara River, is the Front, a park of forty-five acres. Connected with this by a series of tree-lined avenues and spacious parkways is Delaware Park, the largest park in the city, containing about 365 acres. Part of this park, with the Park Lake, is contained in the Exposition grounds, the rest is taken up by the broad meadow and surrounding woods and drives. Turning east along Humboldt Parkway, we reach Humboldt Park, with its wading pond, the delight of the children, and a handsome lily pond. In the south part of the city are three parks, one at Stony Point of 62 acres, Cazenovia Park of 82 acres, and South Park of 150 acres. In South Park are the Botani. cal Gardens. Scattered over the city are numerous small parks and squares that afford breathing spaces for the public. Buffalo's streets are so lined with trees that nearly all of them seem like parkways.

\section{STATE HOSPITAL FOR THE INSANE.}

On Elmwood avenue, near the Exposition grounds, is the largest public institution in Buffalo. This is the State Hospital for the Insane, in which there are about eleven hundred patients who receive the best of scientific and humane treatment. It is finely situated and the sur. rounding grounds are as beautiful as the gardener's art can make them. The administration bullding is three stories high and flanked with two lofty towers. On each side are five ward buildings and on the grounds are numerous other buildings such as a conservatory, infirmary, etc. The buildings are in the shape of a bow facing Forest avenue and connected by corridors.

\section{FOREST LAWN CEMETERY.}

On the opposite side of Delaware Park, from the Exposition, is Forest Lawn Cemetery, one of the most beautiful places in Buffalo. It consists of two hundred and sixty acres, enclosed by Main Street, Delavan Avenue, Delaware Avenue, and Delaware Park. The land is rolling and well wooded. Numerous lakelets are scattered over the grounds and are joined by quietly flowing streams. The winding drives and shaded walks lead past the graves and monuments of many noted people. The most striking of these is the great bronze statue of the famous Indian 
The Pan-American Oficial Catalogue and Gudde.

orator, Red Jacket, that ornaments the plot of ground where the it mains of that famous Indian are buried, with other noted chiefs of the Seneca tribe.

\section{WORKING BOYS' HOME.}

The Working Boys' Home is the result of the efforts of the Right Rev. Bishop Ryan to provide a home for the boys who are alone in the city. The old Hammond mansion was bought in 1888. Work began at once on the remodelling and furnishing and in February, 1889, it was ready for occupancy. The Ladies' Aid Society was formed by the Bishop to help carry out the plans of the institution and to them a great deal of the credit for the Home is due. It is a pleasant Home where every effort is made to build up noble character's and keep the boys from evil associations.

\section{EDUCATION.}

The schools of Buffalo number about 60 and can compare in regarl to efficient work and in all other circumstances with any school system In the United States.

They are under the charge of a Superintendent of Education, elected by the people, in whom is vested a great deal of power. There is also a Board of Examiners, from whose lists the superintendent makes ap. pointments of teachers. The remarkable growth of the City has kept the number of schools increasing constantly and as a result most of the buildings are of modern construction. The Central High School on Court and Franklin streets and the Masten Park High School are large, handsome buildings, whose capacity together is about 2,000. Besides these are several annexes and a new West Side High School will soon be bullt.

The University of Buffalo was founded in 1845 and is now in a flourishing condition. It conducts departments in dentistry, law, medi. cine, pharmacy, and pedagogy. The College building on High Street is convenieutly near the General Hospital.

One of the State Normal Schools and also many private, parochial, and denominational schools are located in Buffalo. Some of these schools have more than a local reputation.

\section{TH REGIMENT ARMORY.}

The 74th Regiment Armory is an imposing building of brown stone; built after the style of a feudal castle. The big drill hall is about 310 feet long and 240 feet wide. On the Connecticut Street end of the Armory is the Administration building, about 250 by 350 feet, three stories high. The first floor is occupied by the company rooms, lockers, store rooms, and a great hall, designed as a "Hall of Trophies." On the 


\section{The Pan-American Offotal Catalogue and Guide.}

second floor, the field and staff offcers of the regiment have handsome quarters and there is also a commodious billiard room. The third story is occupied by the quarters of the band and field music, the surgeons and the hospital corps, gymnasium and baths. In the basement there is a rifle range, heating, lighting and ventilating plants, and shower baths. The cost of the entire building aggregated $\$ 400,000$.

\section{POSTOFFICE.}

This magnificent building occupies an entire block bounded by Ellicott, Swan, South Division and Oak streets, and is five stories high. The main front on Ellicott Street is 220 feet in length. In the center of this main front a tower rises to the height of 250 feet. The style of architecture is pure Gothic. The outer walls are faced with pink Maine gmnite and the interior walls with glazed brick and terra cotta. Spanish green tile covers the roof and forms a pleasing contrast to the granite walls.

Glazed brick and marble are used extensively in the inside decorations. The principal offices and court rooms are finished in Mexican mahogany and all other rooms in quartered polished oak.

The Postoffice is occupied by the Postal Department and the various United States Courts and Federal Officers, and was erected at a cost of $\$ 1,500,000$.

ELLICOTT SQUARE.

The Ellicott Square, the largest office building in the world, covers an entire block. It is ten stories high and contains about twelve hundred rooms. The total cost of this great building was about $\$ 3,350,000$. The foundation for the steel frame, which weighs $\mathbf{5 , 5 5 0}$ tons, consists of steel and concrete, extending nineteen feet below grade; the exterior construction is of pressed brick and pearl-gray terra cotta; the interior decorations consisting of Italian marble, marble mosaic and ornamental iron. The finish is of quarter-sawed red oak. The number of people that work under its roof would form a small city by themselves. In regard to the construction of this great building, it may be interesing to know that to build it took just one year.

\section{CITY AND COUNTY HALL.}

On Franklin Square stands the City and County Hall, an imposing and graceful structure. It was begun in 1872 , finished in 1876, and cost about $\$ 1,500,000$. The style of the architecture is Norman, the building is of granite, with iron girders, marble pavement and wainscoting, and finished in a hlghly polished black walnut. The building is three stories in height and contains nearly all the City and County offices and Courts. 
The Pan-American Offoial Catalogue and Guide.

The present City Hall is a model public edifice, and this is acknowledget by all who visit Buffalo. It is a model not only in point of its unusul solidity and beauty and small original cost, but in the perfection of is maintenance.

\section{HACK ORDINANCES.}

Persons to whom licenses shall have been granted for vehicles to be used in the conveyance of persons or passengers or the drivers of such vehicles may charge the following prices and no more:

1. For conveying one passenger any distance not exceeding one mile, 50 cents; and for each additional passenger, 25 cents.

2. For conveying every passenger any distance over one mile and not exceeding two miles, 50 cents; and for each additional passenger half the regular rate.

3. For conveying every passenger over two miles, $\$ 1.00$; and 50 cents for every additional mile, and for each additional passenger hall the regular rate.

4. For the use of any such vehicle for the day for one or mote passengers, $\$ 8.00$.

5. For the use of any such vehicle by the hour, for one or more passengers, with the privilege of going from place to place, and stopping as often as may be required, $\$ 1.50$ for the first hour, and $\$ 1.00$ for each additional hour.

6. Distances shall be measured by the most direct traveled route, and in all cases where the hiring of such vehicle is not at the time specl. fed to be by the day or hour, It shall be deemed to be by the mile.

7. Each passenger shall be allowed to have carried and conveyed upon such vehicle, one trunk, valise, saddle bag, carpet bag, portman. tøau, box, bundle, basket or other article used in traveling, without charge, but for every article above enumerated more than one, carried or conveyed upon such vehicle, the driver shall be entitled to demand and receive the sum of five cents for conveying within the distance of cne mile, and for more than one mile the sum of ten cents. 
The Pan-American Official Catalogue and Guide.

HOTELS AND APARTMENTS.

Buffalo's facilities for caring for the visitors in this respect will be found ample for the accommodation of the many people who will attend the Exposition. The combined hotel capacity is over 125,000 and the large number of boarding houses, private rooming houses, lodging houses and restaurants offer accommodations for as many more. Rates will range from 50 cents a day to $\$ 10$ per day, according to location, though the favorite rates will be from $\$ 1$ to $\$ 2$ per day for rooms, and meals can be procured at the regular uniform rates.

\section{Places of Amusement.}

ACADEMY OF MUSIC-Main Street, near Seneca. Reached by Main, Elmwood, Baynes \& Hoyt, Nlagara, Sycamore, Genesee, Elk and Seneca St. car lines.

COURT STREET THEATER-Court, near Frankiln Street. Reached by same as above, excepting Seneca and Eik St. lines from which transfers can, however, be had.

LYCEUM THEATER- Tashlngton, near Broadway. Reached by Iroadway, Genesee, Sycamore, Miln, Eimwood, Baynes \& Hoyt and Utica St. lines.

IAFAYUTCE TILATER - Lafajette Square, near Main St. Reached by same llues as above.
SHEA'S GARDEN THEATER-Pear!, near Niagara St. Same lines as above Inciuding Niagara St. line.

TECK THEATER-Main, corner Edward. Main, Elmwood, Baynes \& Hoyt, Albany \& School, Dtlca and Main and East Ferry St. cars pass the door.

STAR THEATER - Mohawk, corner Pearl; reached by Maln, Elmwood, Baynes \& Hoyt, West Are. \& Grant, Albany \& School car lines.

DR. LINN'S MUSEUM-Main Strect, corner North Dlvision. Reacbed by Main, Elmwood, Baynes \& Moyt, Niagara, Sycamore and Genesee car lines. 
The Pan-American Official Catalogue and Guide.

\section{Niagara Falls.}

The far-famed falls of Niagara are only half an hour's ride from Exposition grounds, and one may spend a week in the midst of thi magnificent scenery and find new pleasures each day. It is quite te possible to describe the grandeur of these majestic cataracts, whos: ceaseless roar has been heard through countless ages, and which hath for centuries excited the awe and wonderment of savage and cirllib men. The Nlagara River receives the waters of Lakes Superior, Mict: gan, Huron and Erie and discharges them into Lake Ontario. At Niag ara Falls there is a sheer descent of 160 feet. The width of the Falle inciuding Goat Island, which divides the American from the Horsesto Falls, is nearly tour-fifths of a mile. Millions of tons of water plunga unceasingly over these dizzy heights, and surge and seethe in the gorg: below. The gorge itself, with the Whirlpool Rapids and the mighty Whirlpool below them, is scarcely less fascinating and interesting. There is every convenlence here for the comfort and convenience of the slgbt. seer, and all points of interest are of easy access. The State of Ner Iork a few years ago bought the land immediately bordering on the $\mathrm{N}$. agara River at the Falls, together with Goat Island, consisting of in acres, lying between the two great cataracts, and made the whole a public park. On the Canadian side the Ontario Government has also acquired several miles of land bordering the river and gorge, which is free to the public and is known as Queen Victoria Park. From Prospect Park the visitor has his first view of the wonderful scenery. Here he may almost dip his hand into the stream that instantly leaps far out into the deep gorge. Public vans, at a nominal price, will convey hlm across the long bridge over the American Rapids above the Falls to Goat Island, and around this wild and beautiful garden.

The Falls may be viewed from the gorge below by descending the Ineline railway from Prospect Park. Here the steamer "Maid of the Mist". Will carry him well up towards the face of both the American and the Horseshoe Falls. The view is one of impressive and abiding grandeur. The Niagara Gorge is spanned just below the Falls by a vteel arch bridge, so that one may take an electric car at the American side and spend a full afternoon with profit and pleasure viewing the scenery trom Canadian points. A new suspension bridge between Lewis. ton may be crossed by the traveler, where he may take the Gorge Road and return to Niagara Falls on the American side, close to the river's edge nearly the entire distance. This is a ride of most fascinating interest and one learns to realize more fully the irresistible power of the 
The Pan-American Official Catalogue and Guide.

great river current. Observation cars upon the New York Central branch also run between Lewiston and Niagara Falls, and an electric line runs from Lewiston to Youngstown on Lake Ontario at the mouth of Niagara River. Lewiston is also the American port lor a line of

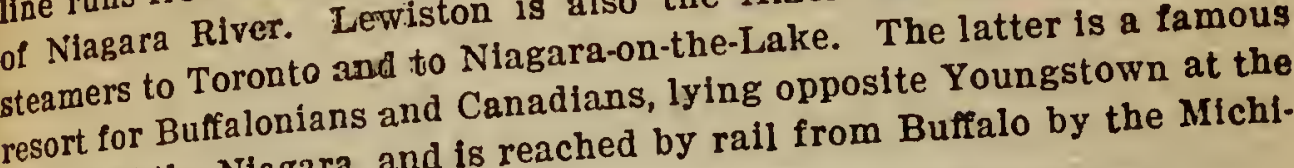
mouth of the Niagara, and is reached by rail from Buffalo by the Michlgan Central Rallway.

\section{POINTS OF INTEREST.}

PROSPECT PARK - This beautiful forest-grove of ten acres is more frequented by visitors than any other place about the great cataract. frequented by visitors than any other place about the New York State Reservation, and contains
The Park is a part of the
Prospect Point, Hennepin View and other fine spots for sightseeing. The park proper has a frontage of 1,000 feet along the river chasm, and of 500 feet above the American Fall.

Prospect Park is headquarters and lunching-place for nearly all picnics and excursions to Niagara Falls. Lunching is permitted in the upper half of the Park only, in the vicinity of the frame buildings.

Street cars convey passengers to the Falls street entrance of the Park, this point being the upper terminus of the Niagara Falls and Suspension Bridge street car line. This line passes the several railroad stations.

The State Reservation carriages carry people from here to Goat Island and return.

The stone building near the Falls end of the Park is the entrance to the Inclined Stair and Railway to the foot of the Fall, and contains the office of the Superintendent of the-State Reservation.

GOAT ISLAND-From its location in the Upper Rapids, causing the river to divide and form two great cataracts, this island of 61 acres is an unequaled point of interest to Niagara visitors.

The surface of the land at the cliff is 205 feet above the water in the gorge below the Falls-higher than any other sight-seeing point so near to the chief object of interest. The loveliness of the sixteen small isles near Goat Island and the fact that the entire group, including it; have been left with the virgin forests almost untouched by the axe, render this spot very attractive.

The trip around Goat Island may be made in any of the public vans at a cost of 15 cents, with as many stop-overs as you may wish. The first stop is at Luna Island, where we go down several flights of steps, cross a substantial stone arch bridge and view the American Falls trom a point between the Bridal Veil Falls and the American. 
The Pan-American Offichal Catalogue and Guide.

A few rods from the head of the stairs, we come to the stains, leading to the Cave of the Winds. It is necessary to wear oill clothing and to proceed with care. The use of the suit and the servece of the guide cost one dollar. You go by the ralled pathway before Bridal Veil and then behind the American Falls, where time and th waters have made a cave, about 100 by 160 feet, well named on accorre, of the tremendous suction caused by the great volume of falling wates This trip may be made with safety, though the deafening roar of th: mighty torrent must ever accompany it.

The next convenient stopping place is at the head of the stairmay leading to Terrapin Rock, at the Horseshoe Falls. Here again we conpe close to the edge of the great fall which we had first visited on the ara and several this, th Island. throu: yet $m$ ara. the $f$ free pass eral Canadian side. The view, whether into the seething waters belor, across the face of the fall, or up stream against the broad waters tur. sen bling onward toward the cliff from which they soon must leap, is im. pressive and fascinating.

UPPER RAPIDS AND THE TWELVE ISLANDS-The locality the Rapids and the twelve picturesque little islands to the north of Goat Island has always been a favorite one with visitors. At this point the river, whose current runs at the rate of seven miles an hour above Goas -Island, speeds over rocky shelves at the rate of 30 miles an hour, as it hastening to make the final plunge. Here are a multitude of rolling cascades and eddies, affording a rare scene of waters in motion. As the general depth of the water is shallow compared with the greater volume of the river beyond Goat Island, the influence of continued east winds in lowering the water, and of continued west winds in deepening it, is more apparent here than at some other points.

THREE SISTER ISLANDS-With these gems of Niagara-lovely sisters they are-you can spend several hours most delightfully. Then you will wish to renew the visit some time. On the hottest days of summer the atmosphere here is remarkably cool and refreshing, and the shade complete. From between scraggy cedars and other growths and from the bridges the eye may gaze on some of Niagara's most enchanting scenery.

The Islands should be visited when the sun shines brightly, for then the extraordinary contrasts of the light on the foam-crests and mists with the deep-green water, verdure and frowning rocks is the most striking.

After a continuous period of east winds the views here are some. what less favorable than at other times. As mentioned elsewhere, a prolonged east wind has the effect of depressing the waters of the Niag. 
The Pan-American Ofioial Catalogue and Guide.

ara and the lower end of Lake Erie as much as one foot, or sometimes several feet, over the entire surface. On rare occasions, as a result of this, there is no water between the ffrst island of the three and Goat Island.

STEAMER MAID OF THE MIST-A trip by passenger steamer through the gorge directly in front of all the Falls is one of the safest yet most thrilling experiences that the tourist can enjoy while at Niagara. By a tortuous course the boat makes it way through eddies along the foot of the cataract and in front of Goat Island, touching at several free landings on the two sides of the river for the accommodation of passengers. From the cabin and deck the visitor may behold the several Falls to the best possible advantage from below.

The waterproof clothing is furnished without extra charge to passengers. The fare for the round trip is 50 cents.

THE GORGE ELECTRIC RAILROAD-Skirting as the road does the very water's cdge of the canon below the Falls, the visitor is introduced at close range to scenery of the most magnificent character. Here we are brought in close contact to the Niagara's waters, as they in places shoot with tremendous rapidity towards Lake Ontario, impelled first by the momentum gained in the great fall, second by the rapid descent in the river's course below the cataract.

Cars for this trip are taken at Prospect Park, where they leave at intervals of a few minutes in the summer, and less often in the winter. The length of the road is seven miles, time of round trip without stops one hour and thirty-five minutes, fare 35 cents one way, 60 cents both ways, with stop-off privileges.

The main attractions of the route, some of which will be found treated in detail elsewhere, are as follows: About one mile below the Falls the road descends by easy grade to the water's edge, which is reached almost underneath the railroad bridges. Half way down this grade the tourist gains one of the finest views to be had of the Falls, as here they are beheld a mile away, set as it were between the rising cliffs on either side of the gorge. It is a magnificent spectacle and one that only was made available with the completion of the present road.

Moving along down to the water's edge, first we pass under the railroad bridges, then meet the marvelous whirlpool rapids, of which a near view is had for their entire length. Here a stop is made and an ascent can be effected by elevator to the banks above.

Returning to the car, or rather a succeeding one, the tickets being good on any of the cars, the Great Whirlpool, with its perpetual vortex is soon passed, and then in succession the lowest rapids, the Giant Rock, 


\section{The Pan-American Onicial Catalogue and Guide.}

the Narrows, the Devil's Hole, gully and cavern, the ruins of the the Suspension Bridge over Niagara Gorge, Queenston Helghts, Brow Monument, ending up at the beautifully expanding lower river and historic village of Lewiston.

THE WHIRLPOOL RAPIDS-At this point, exactly two miles beter the American Fall, may be witnessed one of the most wondertul sigut in the world. It is the Niagara - the mighty river combining the Haten of the five great American lakes, and sufficient in places elsewhere form a stream two miles wide and twenty feet deep-here ton through a rocky defile, in places less than one-seventeenth of a mill wide, the enormous volume of water being hurled forward at 40 mile an hour. The furious momentum of the Lower Rapids is created bf the great cataract and by the river's descent of 98 feet in seven miles belor the Falls to Lewiston. The remarliable constriction of the vast rive rortex being together with the large rocks beneath the surface, throws its deep rater into the most extraordinary turmoil, and causes them in places to riv no less than 20 feet above the ordinary level in tremendous foam crowned masses, far too much agitated to be called waves.

Excellent means for viewing this unexampled scene are afforded b safe platforms erected at the river's edge on both sides, and reached bs power conveyances. The price for descent and return on either side 0 the river by the elevators is 50 cents. A fair general view of these tin rapids may be had from the Lower Suspension Bridge and from the edga of the cliffs on the Canada side.

THE WHIRLPOOT-Situated one mile below the railroad suspen. sion bridge and immediately beyond the Whirlpool Rapids, is the famous Niagara Whirlpool, a wonderfully formed oblong recess at the point of a sharp right-angle in the river. The pool, which is about one-third of a mile long and one-fourth of a mile wide, is shut in on all sides, says the two openings of the river, by rocky walls 250 feet high. Visitors can reach the water's edge on both sides of the river. On the Canadlan side, an Inclined railroad admits of this with ease; the charge for a round trip for each person is 50 cents.

From the water's edge observe that the river, yet quite rapid at the entrance of the basin, pours into it in a waved stream somewhat higher in the center. Then it eddies to both sides and seems to be sucked under and spurted out again. It then spreads out on both sides and courses round and round, finding its egress down stream eventually, as here it is not intercepted by the powerful incoming current. Notice logs, trees and other floating substances that have been drawn into the 
The Pan-American Omcial Catalogue and Guide.

vortex, many of which circle round and round for days and weeks before being drawn down.

RAILROAD BRIDGES-The Lower Suspension and Cantilever rallroad bridges, two mlles below the Falls, are objects of considerable interest. The river at this point is about 400 feet wide, and the bridges are over 230 feet above the wild and deep raplds below. The first-named bridge has, besides the rallroad-bed, a separate floor for vehicles and pedestrians. The other is not open to the public. A charge of 10 cents is made for entering or crossing the Lower Suspension Bridge.

The first suspension bridge was thrown across the chasm here in 1840. It consisted mercly of a $7 / 8$-inch wire cable on which was suspended a basket large enough to hold two persons. It was worked by a windlass on each bank. The first cord was passed over the river by the aid of a kite.

\section{CARRIAGE HIRE.}

In hiring a carriage, take the number and arrange for the price, time and places to be visited before starting. In case no rate is agreed upon, the law of the corporation of Niagara Falls provides the followlng:

From one place to another in the village of Niagara Falls, 50 cents for one person and ordinary baggage (one trunk and one bag, hat or bandbox or other small parcel); 25 cents for each additional person and baggage.

From Niagara Falls to Suspension Bridge, one person and ordinary baggage, \$1: each additional person, 50 cents.

Children under three, tree; from three to fourteen, half price.

Carriages for points beyond and within five miles of the village line, whether one or more passengers are carried, $\$ 2$ for the first hour; $\$ 1.50$ for each additional hour.

For a carriage drawn by one horse, $\$ 1.50$ for first hour; $\$ 1$ for each additional hour occupied. 


\section{Buffalo Hotels.}

Below is given a list of hotels with their location, capacity and a per day. Those marked Family Parties are suitable for ladies. ? entire list has been inspected and approved by the Pan-American an sition Company:

\section{AMERICAN PLAN-FAMILY PARTIES.}

Name.

Johnson ...........284 Delaware ar...... 300

Castle Inn ............ Nlagara sq \& Delaware ar. 250

Wm. E. Garbe........2865 Main st........ 35

Vendome ...........37-39 Court st....... 175

The Cheltenham.......234 Frankiln st....... 180

Moeller House ......... Scott \& Maln sts...... 175

Mansion House.......... Exchange \& Main sts.... 450

Stafford House........ Washlngton \& Carroll sts.

National ............. Exchange \& Ellicott sts...

John McConnell .......93 Massachusetts st.....

Southern ............. Seneca \& Michlgan sts.....

Continental ........... Exchange \& Michlgan sts..

Trubee \& Annex.......414 Delaware ar.......

Leydon ............138 Exchange st............

Tremont House......... Washington \& Seneca sts.. 150

Normandle .........660 Main st......... 95

Vosseller $\ldots \ldots \ldots \ldots \ldots 11$ Bull st............. 60

Polish ................... 80

Statier's ............ Elmwood \& Forest aves.... 5000

Broezel ............. Seneca \& Wells sts...... 450

Temperance .........220-222 Ellicott st..... 60

Flilmore House.......... Michlgan \& Carroll sts... 180

(Statier's price includes breakfast and six o'clock dinner.)

\section{EUROPEAN PLAN-FAMILY PARTIES.}

Name.

Iroguols

Location.

Lenox

New Tifit Houss

Bucklngham

Marlborough

Lincoln

Roanoke

Winona

Albemarle

Ashland Colonlal.

Aberdeen

Kenllworth

Rockford
Maln \& Eagle sts........ 1000

. North, near Delaware av.. 600

.465 Maln st.......... 550

. Allen \& Mariner sts...... 120

.Allen \& Marlner sts..... . so

14th \& Rhode Island sts. . 220

.156 West Chlppewa st.... 100

200

200

100

200

300

200
Rate.

$\$ 2.50$ per das.

$\$ 3.00$ and up.

$\$ 2.50$ per das

$\$ 2.50$ and up.

$\$ 3.00$ per das

$\$ 1.50-\$ 2.50$.

$\$ 2.00$ and up

$\$ 2.00$

$\$ 2.00$

$\$ 2.00$ per day.

$\$ 2.00$

$\$ 2.00$ and up.

$\$ 2.00$ per da?

$\$ 2.00$ and up.

$\$ 2.00$

$\$ 2.00$ per das.

$\$ 2.00$

$\$ 2.00$

$\$ 2.00$ and up.

$\$ 4.00$

$\$ 2.00$ per day.

$\$ 2.00$ 
Name.

Location.

Capacity. Rate.

City .................Mlchigan \& Exchange sts. 150

Genesee ..............Main \& Genesee sts..... 450

Nlagara ................ Porter, Seventh \& Front.. 400

The Annex ........... Swan \& Pearl sts...... 200

Twentleth Century ......Amherst \& Delaware..... 150

Victorla ............... Niagara, Eagle \& Franklln

Voss Hotel...........999 William st.......

Bralnard House ........1039 Willlam st.......

Stock Exchange.........1009 William st.......

Carlton .............. Exchange \& Washington..

Carl Volker ..........572 Amherst st........

Kellogg ...........260 Franklin st.......

Mrs. John McCarty...... 190 Niagara st........

H. Buete ............136 Hampshire st.....

R. Palmerton ........441 Forest a

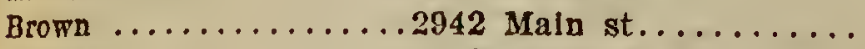

Glendale $\ldots \ldots \ldots \ldots \ldots 2073$ Main st.........

Chapln ............... Delawrare \& Lancaster ar ..

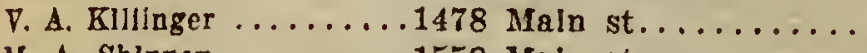

M. A. Shlppey........1558 Main st.........

Christ Petre ..........162 Landon st.........

Barnes $\ldots \ldots \ldots \ldots \ldots \ldots .278-280$ Pearl st.........

Barton $\ldots \ldots \ldots \ldots \ldots$. W. Ferry \& Barton sts...

Y. I. C. A............ Genesee \& Davis sts.....

Margland Cottages.......105-11 Maryland-303 Front

Irvington $\ldots \ldots \ldots \ldots \ldots 351$ Washington st.....

New Gruener.......... Washington \& Huron sts..

The Plaza...........942 Main st..........

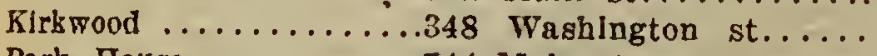

Park House.........744 Maln st...........

Mrs. E. M. Bedell . . . . . 238-240 Elmwood a. .... 132

St. Mary's Home (women only), 125 Edward st..... 77

Robinson ..................... \& Washington sts.. 175

Plerpont ...........59 Whltney pl....... 100

Northland .......... 385-387 Ellicott st..... 80

The Raleigh .........352 Franklln st....... 275

Alcazar ....................... 500

Columbia ........................... 800

Epworth Cottage..........Ledger, near Hertel av... 80

Forest ............228-230 Forest ar...... 65

GIbbs .............1005-1021 Elmwood av... 1000

Park .................mherst \& Delaware at... 1000

Women's Chrlstlan Ass'n..266-68-70 Grote st...... 300

Fornes ............. Court \& Pearl sts........ 150

Ansteth ...........1067-1073 Grant st...... 200

Zenobla ............16-18 Prospect av...... 80

Lackawanna ........62-64 Maln st........ 450

Coraell ...........1200 Main st......... 100

Massrchusetts .........694-696 West ar....... 50

$100 \$ 1.50$ per day.

$50 \$ 1.50$

$\$ 2.00$ and up.

100

225

50

25

75

30

100

60

60

50

20

40

60

125

1.1

75

100

100

$\$ 1.50$

$\$ 1.50$

$\$ 2.00$

$\$ 1.00$

$\$ 1.00$

$\$ 1.00$

$\$ 1.00$

$\$ 1.00$

$\$ 1.00$

$\$ 1.00$

$\$ 1.00$

$\$ 1.00$

$\$ 1.00$

$\$ 1.00$

$\$ 1.00$

$\$ 1.00$

$\$ 1.00$

$\$ 1.00$ and up.

$\$ 1.00$

$\$ 1.00$

$\$ 1.00$

$\$ 1.00$

$\$ 1.00$

$\$ 1.00$

$\$ 1.50$ per daj.

$\$ 1.50$

$\$ 1.50$

$\$ 1.50$

$\$ 1.00$ and lap.

$\$ 1.00$

$\$ 1.00$

$\$ 1.00$

$\$ 1.00$

$\$ 1.00$

$\$ 1.00$

$\$ 1.00$

$\$ 1.00$

$\$ 1.00$

$\$ 1.00$

$\$ 1.00$

RIVerside Park

866-868 Prospect ar.

200

$\$ 1.00$

$\$ 1.00$ per day. 
Name.

Location.

Capaclty. Rate.

Name Paul Voorhees ........935-945 W. Ferry st..... 375 C. B. Carrick. .........20 Exchange st........ 80 D. G. Mcluead............Exchange \& Wells sts.... 100 Arlington ............. Exchange \& Wells sts.... 200 C. H. Lowrey .........73-75 Maln st........ 150 Russell House........39-41-43 Swan st...... 160

$\$ 1.00$ pet 243. .50 " verdow $\$ 1.00$ and aph Louls $\mathrm{F}$. $\$ 1.00$ $\$ 1.00$ $\$ 1.00$

\section{EUROPEAN PLAN-MEN ONLY.}

Name.

John H. Mallon......... Cinnton \& Milchlgan.....

Mrs. M. D. McGulre.....295 Fulton st......... Murray Hotel........47 E. Mohawk st....... Henry Oertel 823 Washlngton st...... Davld Pallister........574 Washlngton st......

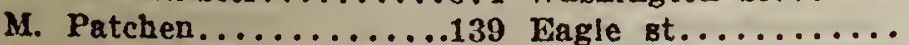

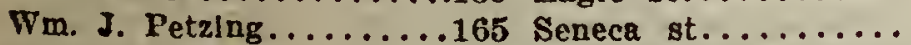
Geo. L. PInzel........485 Narth Division st.... Andrew Rlchard........437 wlllcott st........ Rosenberger Bros......... Michigan \& Eagle sts. . . . . . Edward Sell ...........182 Broadway .......... Fred C. Speucher.......146 Goodell st.......... J. E. Frant............ Conservatory, W. Ssneca.. Louls W. Yauch.......2455 Seneca st......... H. A. Socwell.........950 Grant st.......... Wm. MeFrarland.......... Smith \& Prenatt sts...... Forrestel \& Strlch........ E East Seneca st........ Fulton Hotel............ Oak \& Clinton sts.......

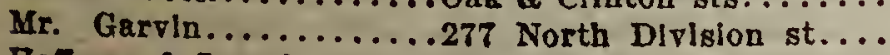
Hoffman \& Laml $. . . \ldots \ldots . . .651$ Maln st........... Mrs. Rose Elser........... Exchange st........

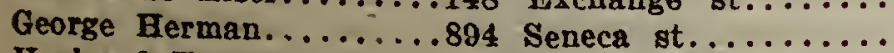
Healez \& Turner........243 North Division st.... Fred Warren............................

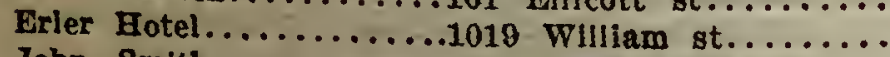
John Smith.................llimore av \& C st........ H. P. Eyring...........

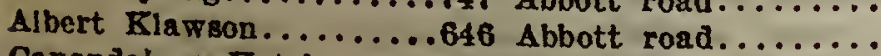
Canandalgua Hotel...........Mlchigan \& Seneca sts.... Carollna Hotel...........112 Main st..........

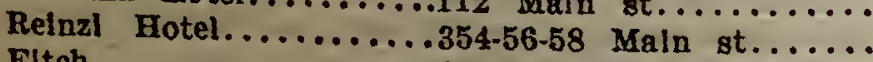
Fitch Olymple

T. J. Murphy.

.63 Maln st.............. John Scheer

John G. Seeger Dunning Hotel.......... Grand Central Hotel..... Clinton st.......... Y. sk. C. $\Delta . \ldots \ldots \ldots \ldots \ldots$. Clinton \& Elllcott $\ldots \ldots \ldots$

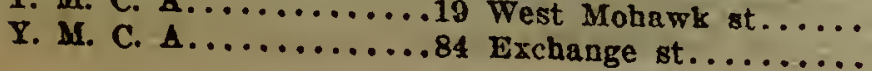

Capacity. Rate. 20 14 6 24 30

8

12

14

18

10

22

8

15

25

30

16

75

54

16

10

125

18

80

20

81

75

6

18

30

30

150

150

51

50

10

40

75

24

90

100

100

$\$ 1.00$

$\$ 1.00$

$\$ 1.00$

$\$ 1.00$

$\$ 1.00$

$\$ 1.00$

$\$ 1.00$

$\$ 1.00$

$\$ 1.00$

$\$ 1.00$

$\$ 1.00$

$\$ 1.00$

$\$ 1.00$

$\$ 1.00$

$\$ 1.00$

$\$ 1.00$

$\$ 1.00$

$\$ 1.00$

$\$ 1.00$

$\$ 1.50$

$\$ 1.50$

$\$ 1.50$

$\$ 1.50$

$\$ 1.50$

$\$ 1.00$

$\$ 1.00$

$\$ 1.00$

$\$ 1.00$

$\$ 1.00$

.75

.75

.75

$\$ 1.00$
$\$ 1.00$ per day.

$\$ 1.00$ and up.

$\$ 1.00$ per day.

$\$ 1.00$ and up.

$\$ 1.00$ per day.

.75

.50 to $\$ 1.00$.

.50 per day. 
The Pan-American Ofloial Catalogue and Gutale.

Name. Location. Onited States Hotel.....22 Pearl st......... 300 Meadow Vlew Ilotel...... Crescent \& Colvin st..... 200 Louls F. Kirst.........914 Genesee st........ 60 Crystal Hotel...........Elllcott \& Clinton....... 100 Stricht ................ Eillcott \& Furon sts..... Villa Hotel............... North Dirision \& Oak.... Cosmopolltan Hotel........Swan \& Washington sts.. Wm. Heberiy............. Front \& Porter a ....... Peter Campbell........530 Rhode Island...... J. H. Delalr..........196 Rhode Island st..... F. H. Davls...........109 Chenango st........ Conrad Goetz..........367 Vermont st......... Tiroll Hotel..........389 Washlngton st..... W. J. IfcCormac.......26 South Park a ....... Rlchard Crowley..........Lafayette \& Nlagara sts.. R. Savllie............839 West a ......... Jas. H. White.........86 Forest av.......... W. W. Mang...........2662 Delaware a...$\ldots$. George Miller.........264 Genesee st........ George Dlebold.......... Parade House.......... P. J. Kavanaugh.........Perry \& Van Rensselaer.. John Langford............Alabama \& Elk sts...... Bamero Plttaro........243 West Genesee st..... George M. Mullen......ti Lakerlew av........ M. J. Klefe...........140 Seneca st.......... Butler \& Garvin........134 East Eagle st....... Thomas J. Dlggens......120 North Divislon st.... Mrs. J. F. Mathews.....47 Oak st........... Murphy \& Sutberland....125 East Eagle st....... White Llne Hotel......51 East Genesee st...... Mackinaw Hotel.......258 Ohlo st., near Moore.. Mr. B. W. Ward.......t14 Swan st......... John Walsh.........49 South Dirislon st...... Alexander Turnbull......1012 Genesee st........ Frank Beer............Carroll \& Van Rensselaer. Ross Sauter..........288 Triangle st....... Jim Smlth............. Myrtle ar \& South Cedar.. John T. Fulton........390 Michlgan st........ J. H. Gllbert............ Sycamore \& Fillmore av.. J. Singer............234 Ellicott st......... McKay Hotel.........40 East Eagle st.......

\begin{tabular}{|c|c|c|}
\hline Capacl & & tte. \\
\hline 300 & .50 & to $\$ 2$. \\
\hline 200 & .50 & to $\$ 1$. \\
\hline 60 & .75 & per day. \\
\hline 100 & $\$ 1.00$ & $"$ \\
\hline 50 & $\$ 1.00$ & $" 6$ \\
\hline 60 & $\$ 1.50$ & and up. \\
\hline 50 & $\$ 1.00$ & 46 \\
\hline 14 & $\$ 1.00$ & per day. \\
\hline 18 & $\$ 1.00$ & "6 \\
\hline 40 & $\$ 1.00$ & " \\
\hline 25 & $\$ 1.00$ & $\omega$ \\
\hline 30 & $\$ 1.00$ & " \\
\hline 19 & $\$ 1.00$ & $"$ \\
\hline 25 & $\$ 1.00$ & 11 \\
\hline 26 & $\$ 1.00$ & " \\
\hline 20 & $\$ 1.25$ & “ \\
\hline 100 & $\$ 1.00$ & 4 \\
\hline 52 & $\$ 1.00$ & 4 \\
\hline 170 & $\$ 1.00$ & “6 \\
\hline 145 & $\$ 1.00$ & 46 \\
\hline 25 & $\$ 1.00$ & 66 \\
\hline - 8 & $\$ 1.00$ & $"$ \\
\hline 20 & $\$ 1.00$ & "s \\
\hline 24 & $\$ 1.00$ & $“$ \\
\hline 50 & $\$ 1.00$ & "6 \\
\hline 18 & $\$ 1.00$ & " \\
\hline 10 & $\$ 1.00$ & “ \\
\hline 60 & $\$ 1.00$ & $"$ \\
\hline 75 & $\$ 1.00$ & " \\
\hline 24 & $\$ 1.00$ & $"$ \\
\hline 75 & $\$ 1.00$ & s \\
\hline 200 & $\$ 1.00$ & $"$ \\
\hline 150 & $\$ 1.00$ & “6 \\
\hline 50 & $\$ 1.00$ & "6 \\
\hline 12 & $\$ 1.00$ & $" 6$ \\
\hline 44 & $\$ 1.00$ & $"$ \\
\hline 16 & $\$ 1.00$ & $"$ \\
\hline 20 & $\$ 1.00$ & $\omega$ \\
\hline 24 & $\$ 1.00$ & $" 1$ \\
\hline 100 & $\$ 1.00$ & 4 \\
\hline 90 & $\$ 1.00$ & " \\
\hline
\end{tabular}


BANKS AND TRUST COMPANIES. American Exchange Bank, 220 Main. Bank of Buffalo, $236 \mathrm{Maln}$, corner Seneca.

Buffalo Loan, Trust \& Safe Deposit Co., 449 Main.

Buffaio Savings Bank, Main, N. E. corner Huron.

Columbia National Bank, Prudential Bullding.

City Natlonal Bank, 319 Main.

Citlzens' Bank, 561 Whilam, corner Sherman.

Commercial Bank, 26 West Seneca, corner Pearl.

Empire State Savings Bank, 174 Pearl, corner Niagara.

Erle County Savings Bank, 344 Main, corner Nlagara.

Fidelity Trust \& Guarantee Co., Main, corner Church.

German Bank, 447 Main, corner Broadway.

German-American Bank, $428 \mathrm{Main}$, corner Court.

Manufacturers' and Traders' Bank, 270 Main, corner Swan.

Marine Bank, 220 Main, S. W. corner Seneca street.

Merchants' Bank, 208 Main.

Metropolitan Bank, 485 Maln, corner Mohawk.

People's Bank, 257 Wrahington.

Third National Bank, 275 Main, corner Swan.

Union Bank, 498 Main, corner Mohawk.

Western Savings Bank, 438 Main, corner Court.

TELEGRAPH COMPANIES.

Postal Telegraph \& Cable Co., 207 Main. Branch offees :

56 Main.

Hotel Iroquois.

22 Palace Arcade.

Mooney-Brisbane Bldg., second floor.

141 Michlgan.

Board of Trade.

100 Lakevlew arenue.

187 Tonawanda.

Prudentlal Bullaing.

Mutual Life Bullaing.
64 Exchange.

Jacob Doid Packing Co.

Snow Steam Pump Works.

Morgan Buliding, first boor corner B

Niagara, corner Margland. Bullders' E

Maln, corner Seneca.

Ganson, corner Mlchigau.

Continental Hotel.

15 1-2 Wadsworth street.

Western Union, corner Maln and 8

Branch offices :

Room 35 Board of Trade.

319 Main (City Natlonal Banl:

Erle County Bank Bullding.

537 Main.

943 Maln.

935 West Ferry.

488 William.

Live Stock Exchange.

173 Perry.

211 Vermont.

413 Nlagara.

Tifft Houge.

Hotel Broezel.

Exchange Street Depot.

Erie Rallway Depot.

1593 Nlagara.

D., L. \& W. Rallway Depot.

Chapis

Iraln an

City Nati

Divlsior

city and

betwee?

Churct

Coal anc

Washl

Coit BlC

Columbl

Custom

eca.

Ellicot

Was

Erle

Mal

Esch:

Fire

$\operatorname{cor}$

Fitcl

Forr

Fral

104 Main street.

$\mathrm{Wm}$. Hengerer $\mathrm{Co}$.

2431 Main street.

Chapin \& Co., D. S. Morgan Bldg.

a

Fra

Ger

Anchor Line Office.

Snow Steam Pump Works.

Pullman Co., East Buffalo.

Lehigh Valley R. R. Depot.

Erle Rallway Station, East Buffab

Erie Rallway Station, Kensingtor Larkin Soap Co.

OFHICE AND OTHER PUBLIC BUILDINGS.

Amerlcan Block, Main between Cout and Eagle.

Austin Flre Proof Bullding, 110 Frant: lin.

Beecher Bullaing, 64 South Divislon, corner Ellicott.

Bapst Bullding, Seneca, corner Wast. ington. 


\section{The Pan-American Official Catalogue and Guide.}

Board of Trade Bullding, Seueca, corner Fearl.

Brown Bullding, Maln, corner Seneca. Buffalo Library Bullding, Washington, corner Broadway.

Bullders' Exchange, Court, corner Pearl. Chapln Block, West Swau, between Maln and Pearl.

Clty Natlonal Bank, Maln, near South Dirislon.

Clty and County Hall, Franklln Square, between Franklin, Delaware avenue, Church and West Eagle.

Coal and Iron Exchange Bullalng, 257 Washington.

Colt Block, Pearl, corner West Swan.

Columbla Bullding, 101 to 107 Seneca.

Custom House, Washington, corner Seneca.

Elllcott Square Bullding. Maln, Swan, Washington and South DIvision.

Erle County Savings Bank Bullalng, Maln, Nlagara, Pearl and Church.

Exchange Building, 196 to 202 Maln.

Flre Department Headquarters, Court, corner Staats.

Fitch Creche Bullding, 159 Swan.

Fornes Bullding, Court, corner Pearl.

Franklin Block, Franklln, between Erle and West Seneca.

Franklln Hall, over 50 West Eagle.

German Insurance Co. Bullding, Main, corner Lafayette.

German Young Men's Association BulldIng, Maln, corner Edward.

Germanla Block, 820 Maln.

Granlte Block, Maln, between Seneca and Swan.

Greene's Block, Washlngton, corner N. Division.

Prudential Bullding, Pearl, cor. Church. Harvey Block, Main, corner Swan.

Hayen Bullding, Main, corner Seneca.

Hutchinson Bullding, 73 Test Eagle.

Kremlln Block, Maln, between Nlagara and Eagle.

Ǩremlín Hall, West Eagle, corner Peari. Lehigh Valley Bullding, Maln, corner Seneca.

Lewls Block, Washlngton, S. W. corner Swan.

Llberty Block, Chlppewa, corner Pearl.
Live Stock Exchange, Wlllam and Depot.

Market Hall, Ellicott, opposite Market. Masonic Temple, 41 to 45 Niagara.

Matthews Bullding, Washington, corner Exchange.

Merchants' Exchange, Board of Trade Bullding, West Seneca, corner Pearl. Mooney-Brlsbane Bullalng, Maln, corner Clinton.

Morgan Bullaing, 544 Maln.

Morgan, D. S., Bullding, Niagara, corner Pearl.

Municipal Court Bullding, 34 Delaware avenue.

Palace Arcade, 617 Main.

Root Building, Wells, corner Carroll.

Spaulding Exchange, Maln, corner Terrace.

\section{MILITARY.}

74th Regiment Armory-Bounded by Connectlcut, Nlagara, Prospect avenue and Vermont street. Take Nlagara Street Car Line.

65th Regiment Armory-New York State Arsenal, Broadway and Potter street. Take cars of the Broadway Line.

PRINCIPAL CHURCHES.

Asbury (Methodist), Pearl and Chippewa Streets.

Ascension (Episcopal), North Street and Linwood A venue.

Calvary (Presbyterlan), Delaware Avenue, near Tupper.

Central (Presbyterlan), Genesee and Pearl Streets.

Church of Our Father (Unitarian), Delaware Avenue, near Mohawk Street.

Church of the Messlah (Unlversallst), North and Marlner.

Delaware Avenue (Baptlst), Delaware Avenue, near Bryant.

Delaware Avenue (Methodist), Delaware Avenue and Tupper.

Flrgt (Presbyterian), Wadsworth Stree: and the Circle.

North (Presbyterlan), Maln, near Chlppewa Street.

People's

(Congregatlonal),

Nlagara

Square. 


\section{The Pan-American Offoial Catalogue and Guide.}

St. Joseph's Cathedral (Cathollc), Swan and Frankiln.

St. Louls' (Cathollc), Main and Edward Streets.

St. Paul's (Episcopal), Main, Erie and Church Streets.

Temple Beth Zion, Delaware Avenue, near Allen Street.

Trinity (Eplscopal), Delaware Arenue, near Tupper Street.

Westminster (Presbyterlan), Delaware Avenue, near North.

st. Peter's (Catholle), Main, corner Best.

Lafayette Avenue (Presbyterian), Lalayette, N. E. corner of Elmwood.

MASONIC TEMPLE.

11-45 Nlagara Street, near Maln Street.

ODD FELLOWS' TEMPLE.

Wullam Street, near Jefferson.

\section{MEDICAL COLLEGES.}

Unlversity of Buffalo, High, near Maln. Niagara Unlverslty.

\section{PUBLIC PARKB.}

Botanical Gardens, South Park.

Bennett Park, 273 Clinton, corner Pine. Caxenorla Park, at 1438 Abbott road, and at 2331 Seneca.

Day's Park, at 262 Allen, and 125 Cottage.

Front, The, at 586 Front avenue, corner Porter.

Humboldt Park, at 1108 Fillmore aivenue and 1132 Genesee, corner Best.

Johnson Park, 274-280 Delaware arenue.

Lafayette Square, at $\mathbf{4 1 1}$ Maln, corner Cilnton.

Masten Park, at 236 North, corner Masten.

Park, The, at 665 Forest avenue, and at 2100 sain.

Prospect Parks (two), at 648 Nlagara, corner Porter a venue.

Blverside Park, at 2687 Niagara and at Clty Line.

South Parks, from 951 Abbott road, at function of South Park avenue.

Stony Point Park, on the Lake Front, Juat beyond the Clty Limits.
Terrace Parks, from junction of ware and Church to 180 Couth

Zoo, The, Delaware Park.

STEAMER WHARVES.

Northern Steamship Co., foot of 1 Street.

Cleveland \& Buffalo Transit $\mathrm{C}_{0}$, w Ohio and Illinois.

Anchor Line, toot of Evans Street. Excursion Steamers, foot of Main in Rlver Boats, foot of Main Street; foot of Ferry.

RAILROAD TICKET OFFICES

Buffalo Street Rallway Co., Mala, $\mathrm{S}$. corver Terrace.

Delaware

Depot

Buffalo Traction Co., Maln, N. $\pi$. ner Terrace.

Buffalo, Rochester \& Pittsburg $\mathrm{B}$. 307 Maln.

Canada Paclfic R. R., 233 Maln.

Delaware, Lackawanna \& Wester

R., 289 Main (Ellicott Square).

Maln

Erle De

chang

Hoyt

Cars.

road

EnI

Erie R. R., 309 Main (Euljcott Squ:

Grand Trunk R. R., 285 Maln.

Lake Shore \& MIchlgan Southern,

Nil

Wi Main.

Lehigh Valley R. R., 369 Maln. Michigan Central R. R., 299 Main,

Grani

Er:

ter

New York Central R. R., 377 Main. Nickel Plate (New York, Chicago \&)

Lehl

Louls) R. R., 291 Maln.

Nlagara Falls and Lockport Electric!

R., Main, corner Terrace.

Northern Central R. R., 307 Mala.

Wabash R. R., 287 Main.

Western New York \& Pennsylvanla ?

Negt Shore R. R., 219 Main, cors:

Erle.

\section{CEMETERIES.}

Black Rock German, Hertel avenue. Buffalo Cemetery, PIne Hill.

Concordla, Walden avenue.

Evangellcal, Pine Hill.

Forest Lawn, Maln and Delaware t? trances.

Holy Cross, IImestone Hill.

Holy Rest, PIne Hill.

Howard Free Cemetery, Limestone 
Jewlsh, Pine Hill.

Lake Slde, near Athol Springs.

Slount Hope, Plne Hill.

Potters' Field, LImestone HIII.

Bldge Lawn, PIne Blll.

st. Jobn's Church, Pine HIIl.

St. Stanlslaus, Plne Hill.

Onlted German and French R. C., Plne

Hill.

Zion's Church, Plne Hill.

Buffalo Crematory, Delavan avenue, opposite entrance to Forest Lawn.

\section{DEPOTS.}

Delaware, Lackawanna \& Western $\mathbf{R}$. $\mathbf{R}$. Depot at foot of Maln. Reached via Maln St. Car.

Erie Depot, at 237 Michlgan, corner Exchange. Reached via Baynes and Hoyt, Jefferson, Michigan and Utica Cars. Trains of the following rallroads depart from thls depot:

Erle R. R.

Nickel Plate (New York, Chlcago \& St. Louls) R. R.

Wabash R. R.

Grand Trunk Depot, at 157 Erle and Erie Canal. Two trains dally vla International Bridge.

Lehlgh Valley Depot, at 119 Washlngton, corner Scott. Reached vla Scott, Maln, Genesee, Elk and Sycamore Cars.

Tralns of Lehlgh Valley $\mathbf{R}$. $\mathbf{R}$. Grand Trunk R. R.

New York Central Depot, at 121 Exchange. Reached by Baynes and Hoyt, Mlchlgan, Jefferson and Utica Cars. Trains of the following rallrosds depart from this depot:

Buffalo, Rochester \& Plttsburg R. R. Canadian Paclfic R. R.

Lake Shore \& MIlchlgan Southern R. R.

\section{PRINCIPAL HOSPITALS.}

Buffalo General Hospital, 100 High. Buffalo Homeopathic Hospital, corner Cottage and Maryland.
Buffalo Hospltal (Sisters of Charity), 1883 Mrain.

Buffalo Quarantine Hospltal, 762 East Ferry.

Buffalo State IIospltal, entrance. Weat Forest avenue, near Elmwood a renue. Buffalo Women's Hospltal, 191 Georgla: Chlldren's Hospltal, 219 Bryant.

Emergency Hospital, corner South DIvislon and Michlgan.

Erle County Hospital, 3399 Mraln.

German Deaconess Home, 230 Kingsley.

German Hospltal, 740 Jefferson, opposlte Brown.

Lexlngton Helghts IIospltal, 173 LexIngton arenue.

Maternity IIospltal, 191 Georgla.

Provldence Asylum, corner Maln and Humboldt Parkway.

Riverside Hospltal for Women, 306 Lafayette avenue.

St. Francls Hospltal, 337 Plne.

St. Mary's Hospital, 120 Edward.

U. S. Marlne Hospital, 1883 Maln.

U. B. Marlue Hospital Dispensary, 25 Postoffice Bullding.

Y. M. C. A. Hospltal (East Buftalo Branch), corner Broadway and Balley avenue.

\section{PUBLIC BUILDINGS.}

Albright Gallery of Fine Arts, the Park. Buffalo Library (free), at 421 Wasbington, corner Broadway.

Grosvenor Library, 385 Franklin, S. E. corner of Edward street.

Buffalo Historlcal Soclety, 421 WashIngton, corner Broadway.

Clty and County Hall, at 78 Franklin corner Church and corner Eagle.

City Convention Hall, 392 Virginla, corner Elmwood.

Erle County Almshouse, 3399 Mrain.

Erle County Jall, Delaware avenue, corner Churci.

Erle County Morgue, at 241 Terrace. Erie County Penitentlary, at 418 Trenton avenue, corner Pennsyivania.

Fire Department Headquarters, at 167 Court, corner Staats. 


\section{The Pan-American Official Catalogue and Quide.}

Munlcipal Bullding, 42 Delaware avenue.

New York State Arsenal, at 173 Broadway, corner Potter.

Police Headquarters, Franklin, corner West Seneca.

Postoffce, Ellicott, corner Swan.

Buffalo Art Gallery, Broadway, corner Washington.

74th Reglment Armory, at 711 Nlagara, corner Connecticut.

United States Court House, In new Federal Bullding, corner Elllcott and Swan streets.

Young Men's Christian Association Bullding, Library and Reading Rooms, Pearl, corner Mohawk (one block from Maln street).

United States Customa House, Swan corner Elllcott.

United States Life Saving Station, on Buffalo RIver, opposite foot of Erle street.

Unlted States Weather Bureau, at 146 Pearl, corner Church (Prudentlal Bullalng).

\section{SUBURBAN IINES.}

Buffalo, Depew and Lancaster (color of cars, Yellow) - From Maln and Cllnton to Washington, to Broadway, to City Line, to Bellevue, to Depew, to Lancaster (every 30 minutes).

Bufralo and Gardenvlle-From Seneca street, at the East City Line, to Gar denville, to Ebenezer.

Buteralo and Grand Island-From Nlagara and Hertel avenue to Clty Line, to River road, to Grand Island Ferry.

Butfalo and Hamburg-From Balley avenue line, at Limestone BIll, to Ro. land, to Blasdell.

Kenmore-From Terrace on Maln, to Florence, to Parkside, Hertel, to Virgil, to Kenmore, to Delaware, to Tonawanda (every half hour).

Lockport-Lockport cars run from Maln and Terrace over Main to Erle tracks, to Tonawanda and Lockport. Nlagara Falls Llne (color of cars, Yel-
low)-From Maln and Exchange to Nlagara to Tonawanda street, to $\Delta \mathrm{m}$. herst, to Military road, to Tonen to La Salle, to Niagara Falls.

Tonawanda Line-From Nlagar

Hertel avenue to Tonawanda sta:

O'Nell, to Nlagara boulerard, to ? wanda.

Whllamsville Line-From Clty Lis Main to Eggertsville, to Sngdi? Willamsville.

\section{CITY STREET CAR LINES}

Balles Ave. (color of cars, Dark Ra Terrace and Erle street to Sout vislon, to Cedar, to Swan, to th to Bailey avenue, to Sonth Park de to City Line. Returning oper route to Swan, to Terrace and Br? Baynes \& Hoyt Line (color of Green)--From Main and Exchens: Allen, to Wadsworth, to Fourter to Rhode Island, to Chenango, Baynes, to Forest arenue, to En tlon. Returnlng by Forest, to $E$ to Hampshire, to Winter, to Bar. to Vermont, to Serenteenth, to nectlcut, to Normal, to Jerses, Plymouth, to Hudson, to Cottage Day's Park, to Allen, to Main, to eca, to Pearl, to Terrace, to Sali

Best LIne (color of cars, Yellow)to South Division, to Lillicott, to ? per, to Eim, to Best, to Walden Belt LIne. Returning by Best to ? to Swan, to Erle.

Broadway (color of cars, Wine RetiClty Line and Broadway to Waln, Seneca, to Washington, to Brosdr to Clty Line.

Cazenovia Line-From Balley arenus Abbott road, to Cazenovla, to Seni street.

Chlcago (color of cars, Yellow)-ir Erle to South Divlsion, to Chestudu Swan, to Chlcago, to Perry, to El: burg, to Erie Crossing. Returt: over same route to \$wan, to Ters and Erle.

Clinton and Eagle Iine (color of a Red)-From Main and North Dirlis to Eagle, to Emslle, to Clinton, Cliy Line. Returnlng by Clintor Mlchigan, to North Division, to Ital
Euclid on to VIaln, to secticut, isiand, to Brajton, $t$ cut, to Nis Perry, to st vtica -Nlagara Hampsuir Itica, to Returning Street From $\mathrm{Mg}$ ton, to $\mathrm{F}$ Euclid. Elk to $\mathrm{M}$ Seneca.

mpood Dark Re to Virg Exposit Imw00d cars D: change positto! Genesee

Perry

Herman (ow) man $t$ to $\mathrm{Ce}$ Iin. vision Smitl

Gertel Red) to $\mathrm{N}$ Jeffers Darl to I dar, Flor tel sax

Rens! $\mathrm{Re}$ Ea av $\mathrm{Re}$ M Mail 
Connecticut and Brayton Line-From Euclld on Elk to Michigan, to Perry, to Main, to Court, to Niagara, to Connecticut, to Fourteenth, to Rhode Island, to Brayton. Returning by Brayton, to Seventeenth, to Connectlcut, to Niagara, to Court, to Main, to Perry, to Michigan, to Elk.

East Dtica Line (color of cars, Yellow) - Nlagara and Ferry on Ferry to Bampshire, to Winter, to Brayton, to Utica, to French, to Kehr, to East. Returning over same route.

Elk Street Line (color of cars, Wine) From Main and Seneca to Washington, to Perry, to Michlgan, to Eik, to Euclid. Returning from Eucild and Eik to Michigan, to Perry, to Main, to Seneca.

Elmpood Avenue Line (color of cars; Dark Red)-From Main and Exchange to Virginia, to Elmwood avenue, to Exposition. Returning same way.

Eimwood via Utica St: Line (color of cars Dark Red)-From Main and Exchange to Utica, to Elmwood, to Exposition. Returning same way.

Genesee Street Line - Washington and Perry to Genesee, to City Line.

Herman Street Line (color of cars, Yellow) - From Waiden avenue and Herman to Smith, to Peckham, to Spring, to Cedar, to Swan, to Erie, to Franklin. Returning by Firie to South Divlslon, to Spring, to Peckham, to Smith, to Herman, to Waiden avenue.

Hertei Avenue Line (color of cars, Dark Red)-From Main and Hertel avenue to Niagara.

Jefferson Street Line (color of cars, Dark Red)-From Main and Exchange to Koulsiana, to Seneca, to South Cedar, to Swan, to Jefferson, to Maln, to Fiorence, to Parkside a venue, to Hertel avenue, to Exposition. Returning same way.

Kensington Line (color of cars, Dark Red)-From foot of Main street to East Ferry, to Grider, to Kensington avenue, to Balley avenue, to Clty Line. Returning over the same route to foot Main street.

Main St. Line icolor of cars Dark Red) -From foot of Main to Florence, to
Parkside avenue, to Hertel, to Exposition. Returning same way.

Maln Street Line (color of cars, Dark Red)-From foot of Mrain to City Line.

Michlgan and Forest Avenue (color of cars, Dark Red)-From Main and Exchange to Michigan, to Delavan, to Forest, to Elmwood, to Exposition. Returning, Eimwood, Forest to Iinwood, Baicom, Masten, North, Mich:gan to Main and Exchange.

Nlagara Street Line (color of cars, Dark Red)-From Main and Exchange to Niagara, to Hertel avenue.

Deneca Street Iine (color of cars, Dark Red)-From Main and Seueca to Rast Clty Line and Cazenovia Park.

School (color of cars, Dark Red)-Niagara and School to P'lymouth, to Hampshire, to Normal, to Jersey, to Plymouth, to Cottage, to Allen, to Elmwood, to Virginia, to Main. Return. lng over same route.

Sycamore Street Line (color of cars, Green)-From l'erry and Washlngton to Huron, to Sycamore, to Walden avenue, to City Line.

Utlca (color of cars, Green)-Ferry and Niagara, Ferry to Hampshire, to Winter, to Brayton, to Utica, to Main, to Seneca, to Michlgan, to Exchange, to Main, to Utlca, to C'benango, to Ferry, to Niagara.

West-Grant Street Line (color of cars, Red)-From Main and Exchange to Nlagara, to Caroilna, to West avenue, to York, to Plymouth arenue, to Hampshire, to Grant, to Forest avenue, to Eimwood, to Exposition. Returnlng Eimwood, to Forest, to Grant, to Hampshire, to Normal, to Jersey, to Plymouth, to Hudson, to West avenue, to Carolina, to Nlagara, to $\mathrm{Hu}$ ron, to Pearl, to Terrace.

Wliliam Street Iine (color of cars, Red) -From Main and North Division to Eagle, to Michigan, to Willam, to City Line. Returning by Wliliam to Michigan, to North Divlsion, to Main.

Zoo-Jefferson Street Iine, from Jefferson on Main to Florence, to Parkside: Maln to Zoo, to Exposition. Returalng same way. 


\section{Exposition Concessions.}

Frederic W. Taylor, Supt.

Following is a list of the concessions granted by the Pan-di Exposition Co., together with the names and addresses of the sionaries.

ADV. IN TOILET ROOMS-Francls B. Lane.

AERIO CYCLE-E. S. Dundy, N. MIdway.

$\triangle F R I C A N$ VILLAGE-Alrican VIllage Co., 45 Erle Co. Bank Bidg. N. Mldway.

"ALT NURNBERG"-A. E. Esenweln, Mall and Mldway.

ALASKA SOUVENIRS-Arthur C. Jacksou, Alaska Building.

ART CATALOGUE-David Gray, 053 Ellicott Sq., City.

ARODND THE WORLD-F. W. Thompson, N. Mldway.

AUTOMATIC

PHOTOGRAPH MA. CHINES-M. L. Lluqulst, 497 Elmwood Are., City.

AUTOMATIC MACHINES FOR THE SALE OF PINYAN NUTS-MIIIS NOVelty Co., 11 s. Jefferson St., Chlcago.

BADGES, BUTTONS AND MEDALSPan-Amerlcan Badge \& Souvenlr Co., 423 Ellicott Sq., Plaza Klosk.

BECK DESIGN ON FABRICS, \&c.Adam, Meldrum \& Anderson Co., 404 Maln St.

BECK DESIGN ON BICYCLES-G. N. Plerce Co., Maln St., City.

BECK DESIGN DELCALCOMANIEPalm Fechleter \& Co., 3 W. 13th St. New York.

BECK DESIGN ON BAT TIPS AND BOX LABELS-BII \& Caldwell, 538 Broadway, New York.

BECK DESIGN ON PLAYING CARDS

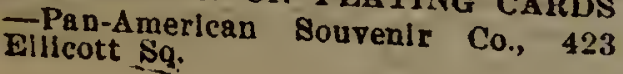

BECK DESIGN ON CLOCE DIT

H. Chouffet, 379 Maln St., Clts. BECK DESIGN ON SMYRNA dXI QUETTE RUGS-The Wm. $\mathrm{B}$ Co., 256 Maln St., City.

BECK DESIGN ON GLASS PA WEIGHTS- Wm. J. Doran, 528 ? dentlal Bldg., City, and Bazast, BECK DESIGN ON LAMPS-Th Reld, 42 Day's Park, City.

BECK DESIGN ON ORANGE LEMON BOX LABELS-Covia? Exchange, $98 \mathrm{~W}$. Mariet St., cht. BECK DESIGN ON WATCHES PARTS THEREOF-W. F. Doll Co., 175 Broadway, New York. BEAUTIFUL ORIENT-Gaston At 401 D. S. Morgan Bldg., Clty, ado Midway.

BECK DESIGN ON NAPEIN AIN TOOTHPICK HOLDERS \& YE PIN TRAYS-Wilbur B. Hall, I den, Conn., and Bazaar.

BECK DESIGN ON CANES AND PII - W. S. Jackson, 31 City Hall, falo, and Bazaar.

BECK DESIGN ON PAPER NAPEI - Nathan Cohen, 41 Emerson PI City.

BECK DESIGN ON HAND BAG TO AND BRACELET CLASPS- Tm Popper.

BECK DESIGN ON POCKET MIRRO $\triangle N D$ MATCH SAFES-Pan-Amert Badge and Sourenlr Co., Plaza kllo BICYCLE CHECKING-Wm. H. Alppe W. Amherst Gate.

BOATING-J. B. Chaddock, 214 St., Clty, and Park Lake. 
BOOTBLACKING AND TOILET ROONS -LI. C. Prichard, 212 Delaware Ave. CARDIFF GIANT-The CardIR Giant Company.

CATALOGUE AND GUIDE-Charles Shrhart, 211 Elllcott St., Clty.

CARRIAGE BOOTHS-C. W. MIller, Buffalo.

CAPTIVE BALLOON-Mark L. Stone, Exposition Grounds.

CELLULOID SOUVENIRS-Thitehead \& Hoag Co., Newark, N. J.

CHlQUITA-F. C. Bostock, The Zoo, Indisnapolis, Ind., and S. Mlddway.

CHOCOLATES AND CHOCOLATE BON BONS-The Walter M. Lowney Co., 445 Commercial St., Boston, Mass., and S. Aldway.

CHOCOLATE AND COCOA-Waiter N. Baker \& Co., 158 State St., Boston, and S. Mldway.

CLEOPATRA-Alonzo Lincoln, N. Mldmay.

COIN SOUVENIRS FROM SLOT MACHINES-Chas. F. Damm.

COLORADO GOID MINE-J. T. HayFard, 663 Maln St., City, and N. Mid"सay.

CONFECTIONERY-Pan-Am. Candy Co., 113 Seneca St., City, and Plaza Blosk.

cUTLERY-Cattaraugus Cutlery Co., Little Valley, N. Y., and Manufacturers' Bidg.

DARKNESS AND DATN-J. J. Dunnavant.

DAILY PROGRAM-Robt. L. Cox, 786 Ellicott Sq., City.

DATSON CITY-E. M. Bayllss, St. Louis, Mo., and S. Midway.

DIVING AND SWIMMING-E. S. McConneil.

EDUCATED HORSE "BONNER"-E. \$. Dundy, N. Midway.

ELECTRIC LAUNCHES-A bergo \& Baronl, 500 Amberst St., Ctty, and S. Midway.

EMBOSSED BECK DESIGN-C. D. Brinkworth, 331 Main St., Clty.

ESKIMO VILLAGE-Labrador ExhIbItion Co., J. G. H. Marvln, Pres., 143 Perry St., and N. Mldway.

FANS-N. Nasr, The Stadlum.

FALL OF BABYLON-J. J. Dunnavant, N. Mldway.

FRUIT-J. A. IfcGlnnis.
GLASS FACTORY - Natlonal Glass Co. Pittsburg, 1'a., N. Midway.

GUM-The Buffalo Sour Pepsin Gum Co., 40 Peari St.

GYPSY CAMP-Enrique Gabardon, N. Midway.

HAWAIIAN VOLCANO \& THEATERE. W. McConnell, 584 Potomac Ave., and N. Mldway.

HOUSE UPSIDE DOWN - Arablan Nlghts Co., N. Mldway.

IDEAL PALACE-Capaceloll \& Sarsi, Elmwood Hotel, City, and S. Mldway.

INDIAN VILLAGE-Gaines \& Cummins, S. Midway.

INFANT INCUBATOR-Dr. S. Schenkein, The Cheitenham, Clty, and S. Mldway.

JAPANESE VILLAGE-Japanese VIllage Co., S. Mldway.

JERUSALEM ON THE DAY OF THE CRUCIFIXION-Percival M. White, 310 Mooney-Brisbane Bldg.

JOHNSTOWN FLOOD-Alfred E. Swift, 712 Prudential Bldg., City, and N. Midway.

LABELS FOR CANNED GOODS-U. $\mathbf{\text { S. }}$ Canning Co., 425 Elllcott Sq., Clty.

LITHOGRAPHED METAL TRAYSChas. W. Shonk, 983 lillcott Sq., City. LOOM CONCESSION-Anderson Bros., Paterson, N. J., and Mach. Bldg.

LOOM CONCESSION-MIss Kate Fearn, Wlndemere, Long Lake, III., and IElec. Bldg.

LOOM CONCESSION-Allen Chesters, Paterson, N. J., and Machlnery Bldg.

LOOM CONCESSION-Taylor Silk Mtg. Co., Paterson, N. J., and Mfrs. Bldg.

MARINE AND FIELD GLASSESCharles W. Dennls.

MEXICAN VILLAGE-H. F. MeGarvie, 7 East Swan St., City, and N. Mld. way.

MICROSCOPES-M. G. Thompson, 93 Yonge St., Toronto, Ont., and Mfrs. Bldg.

MINIATURE RY.-Miniature Ry. Co., 301 Broadway, New York.

MINIATURE WORLD'S FAIR-L. $\mathbf{\nabla}$. Rlce, 1288 N. Clark St., Chlcago, Ill., and N. Mldway.

MIRROR MAZE-J. Francis Brown, 680 Maln St., City, and N. Mldway.

MOVING PICTURES-S. Lubln, $21 \mathrm{~s}$. 8 th St., Phlladelphla, Pa., and N. Mldway. 
NATURAL QUARTZ CRYSTALS-A. B. Crim, Middleville, N. Y., and Mines Bidg.

NEWSPAPERS, ETC.-C. S. A. Coe.

OLD PLANTATION-E. S. Dundy, N. Mldway.

OPTICAL GOODS-M. Brown \& Co., 300 E. 12th St., New York, and Agr. Bidg.

OPTICAL GOODS-J. J. Mannion, 563 Maln St., City, and Machlnery Bldg. OPERA AND FIELD GLASSES-N. Y. Opera Glass Company.

OSTRICH FARM-

PANOPTICON-A. F. Turpln, Panoptlcon, Ex. Grounds.

PAN-AILERICAN PUZZLE-Pan-Amerlcan Puzzle Co., 716 Mutual Iufe Bidg.

PALMISTRY-Leo Bonet, S. Midway.

PENS, PENCILS, \&c. -M. Brown \& Co., 300 E. 12th St., City, and Mines Blag.

PHILIPPINE VILLAGE - Phllipplne Exhiblt Co., 584 Potomac Ave., and N. Mldway.

PHOTOGRAPHS - C. D. Arnold, 123 Bldwell Parkway, clty, and S. Mldway.

PLASTER CASTS-Aug. Langenbahn \& Son, 446 Nlagara St., City.

POTTERY-Geo. W. Parker.

POFCORN \& PEANUTS-G. A. DIrnberger, Elllcott Sq. Court, City, and $\mathrm{N}$. Midway.

PRE-EXPOSITION RESTAURANT Geo. Swanz, 46 Delaware Ave., Clty.

PRE-EXPOSITION POPCORN \& PEA NUTS-G. A. Dirnberger, Enlicott Sq.

RENTAL OF UMBRELLAS \& PARASOLS-T. S. Clarkson, The Cheltenham, Buffalo, and The Stadium.

RESTAURANT-F. J. Balley, 1108 D. S. Morgan Bldg., City.

RESTAURANT - Pabst Brewing Co., Mllwaukee, Wis., N. Midway.

RESTAURANT - Mrs. J. T. McCready, 43 E. Utlca St., City, and N. Mldway.

RESTAURANT - Wm. Hurley, 372 South Park Ave., Buffalo, s. Midway.

RESTAURANT-S. P. Gross, 44 S. Dlvlsion St., Buffalo, and N. Mldway.

RESTAURANT-John Krider, Exposltlon Grounds.

RESTAURANT-G. A. Swanz, Buffalo, N. $Y$.

RICE KITCHEN-Rlce Assoclation of America.
ROLLIRR CHAIRS-Bgron B, If 723 Elllcott Sq., Clty, and Thy
dlum. SCENIC RAILWAT-The L. A. I Son Ry. Co., 150 Nassau St., $X, Y$.
S. Midway. SEATING CONCESSION-MaJor? Clarkson, The Cheltenuam, City,

SHARPENING STONES-Georg!
Lucas, and Bazaar.

SLOT PICTURE MACHINES-B Allen MePherson, 50 Coal \& Imo and N. Midway.

SOFT DRINKS-Buffalo Cones: Co., 320 Ellicott Sq., and N. 1n, SOUVENIR FINGER RINGSArnold, 123 Bldwell Parkway, Cin SOUVENIR WATCHES-R. II. Ing? \& Bro., 67 Cortlandt St., Ner Yor SOUVENIR HORSESHOES-The den Horseshoe Co., Catasauqua, Mach. Bldg.

SOUVENIR MAILING CARDS-1 ara Envelope Co., 117 Seneca St, SOD HOUSE-Mrs. L. Bowser, Clts, position Bldg.

"SPIRIT OF NIAGARA" POSTEB The Goff Co., 1005 Mutual Life Bldg" SOUVENIR SPOONS-American venir Co., Clty National Bank. SOUVENIR CHINA-American $s=$ nir Co., City National Bank.

STADIUM SCORE CARD-Erank Stockbridge.

STAIR LIFT-Stair Lift Compu Nicetown, Pa.

STATUARY-Aug. Langenbahn \& 446 Nlagara st.

TRIP TO THE MOON-F. W. Thow son, N. Midway.

THE GILDED CHARIOT-Frant Bostock, The Zoo, Baltimore, Md., and Midway.

VENICE IN AMERICA-Street। Venice Co., S. Mldway.

WAR CYCLORAMa-A. B. Penfield: Mldway.

WAGONETTES-C. F. Dunbar.

WILD ANIMAL SHOW-Frank C. B tock, The Zoo, Baltimore, $M d_{\text {n, and }}$ Midway.

WOOD SOUVENIRS-Romeyn B. Hous Lowville, N. Y., and Forestry Bldg. WOOD SOUVENIRS-Nelson G. Fre man, Saratoga,. N. Y., and Forestr Bldg. 


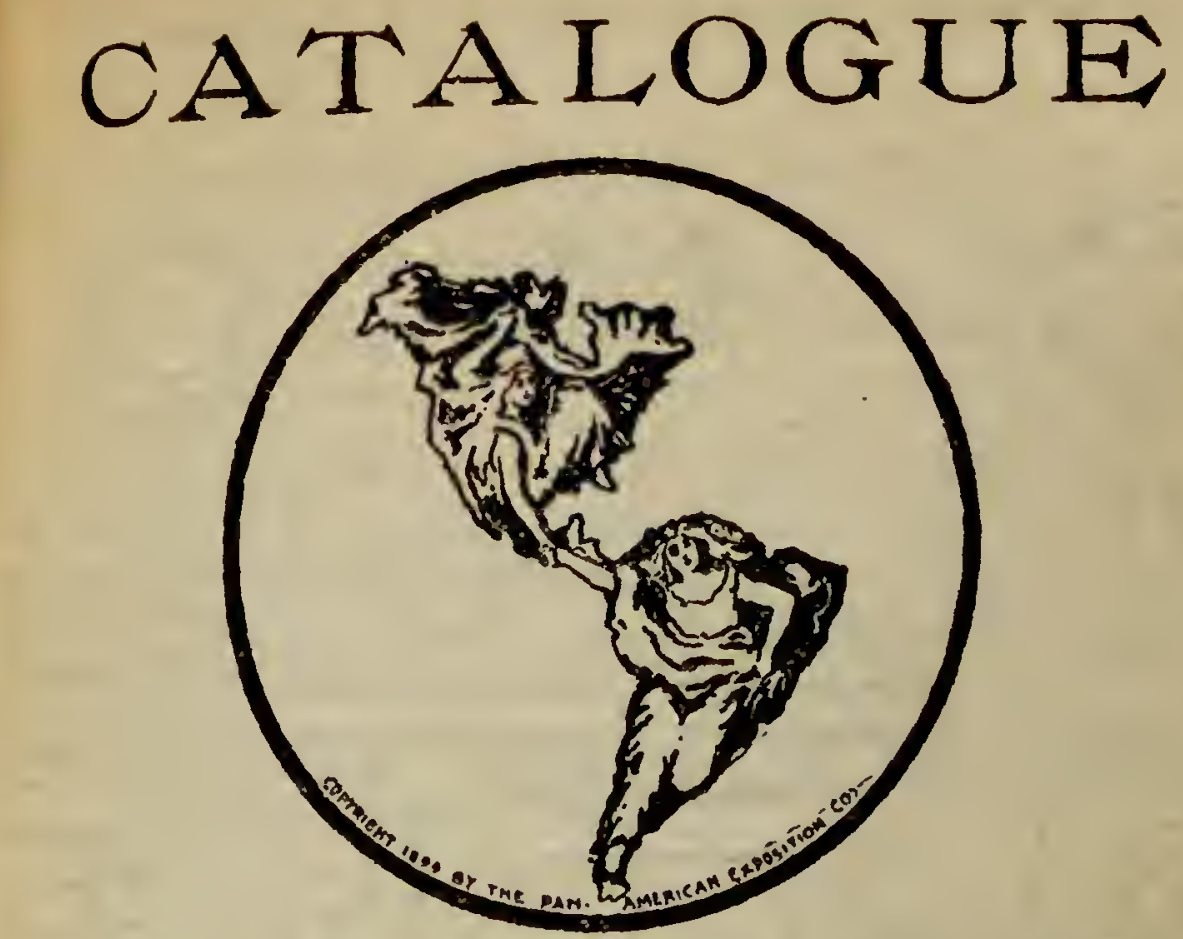

\section{OFFICIAL CLASSIFICATION OF EXHIBTS.}

\section{DIVISIONS.}

AGRICULTURAL AND DAIRY PRO- ORDNANCE AND MUNITIONS OF DUCTS

AGRICULTURAL IMPLEMENTS AND MACHINERY

LIVE STOCK

FOODS AND THEIR ACCESSORIES HORTICULTURE

Pomology

Floriculture

Viticulture

FORESTRY AND FOREST PRODUCTS

MINES AND METALLURGY

\section{MACHINERY}

ELECTRICITY AND ELECTRICAL APPLIANCES

\section{TRANSPORTATION EXHIBITS}

Rallways

Vehicles WAR

MANUFACTURES

GRAPHIC ARTS

Typography

Lithography

Steel and Copper.Plate Printing

Pholo-Mechanioal Prooesses

Drawing

Engraving

Bookbinding

LIBERAL ARTS

Education

Englneering

Publlc Works

Sanitation

Constructive Archltecture

Soclal Economy

Music and the Drama

ETHNOLOGY AND ARCHEOLOGY

FINE ARTS

Palnting

Scuipture

Docoration 
The Pan-American Official Catalogue and Guide.

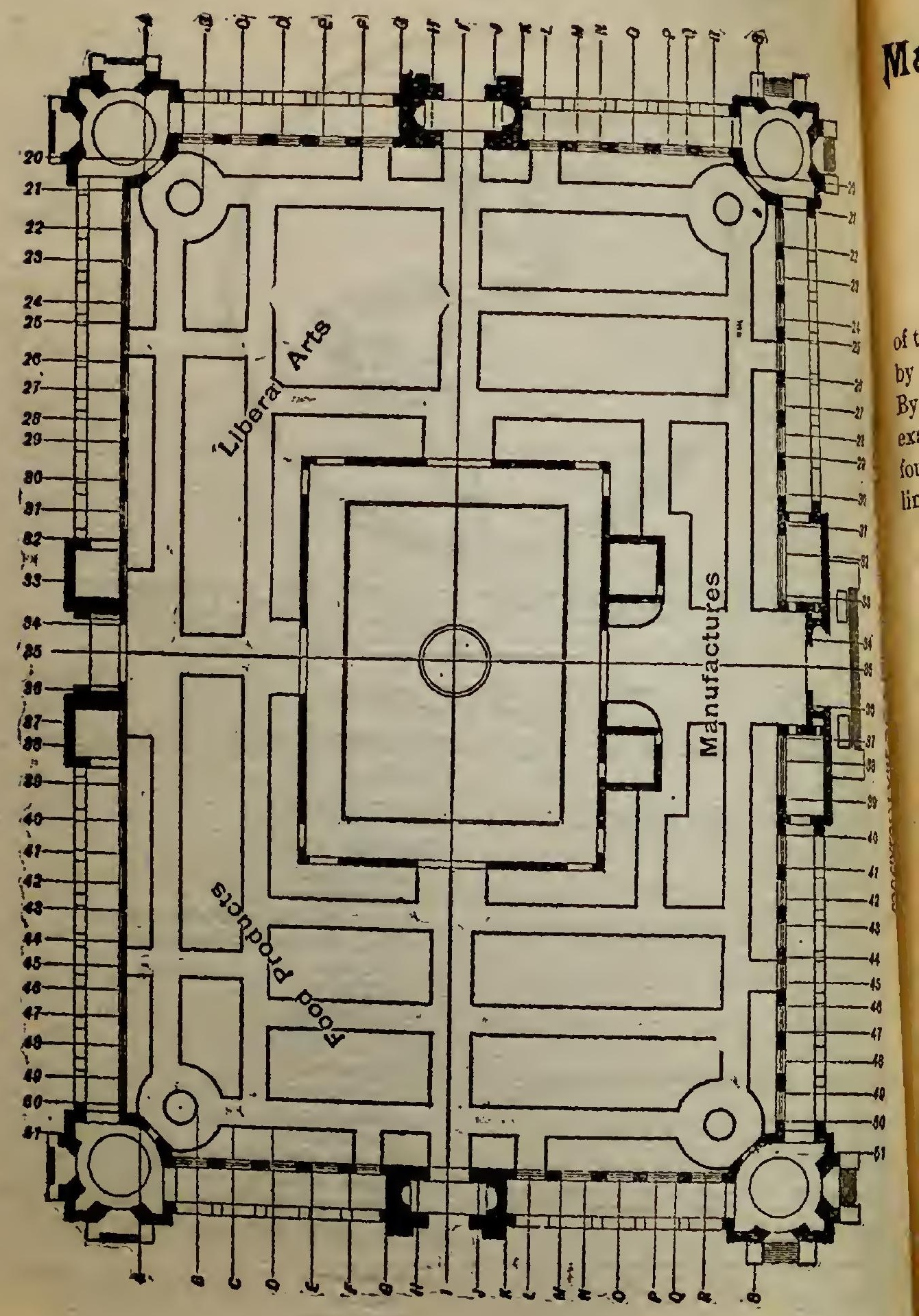




\section{Manufactures and Liberal Arts Bailding.}

KEY TO INSTALLATION.

For the purpose of conveniently locating the exhibits, the ground plan of the building (see opposite page) is divided into sections, which are indicated by the letters $A$ to $S$ in one direction, and by the figures 20 to 51 in the other. By this system each exhibit has a position of longitude and latitude. For. example, an exhibit indicated in the catalogue as being at "I-35," would be found at that point where a line drawn vertically from " 35 " intersects with a line drawn horizontally from I.

Manufaetures Division.

Hige: m. ubaelor, supt.

(Office in East Gallery of Building.)

\section{NATURE OF EXHIBITS.}

General Manufactures, Jewelry, Clocks, Gold and Silverware, Silks, Woolens, Worsteds, Cottons, Dress Goods, etc.

Furs, Fur Clothing, etc.

Chemicals, Paints, Oils, Varnishes, Soaps, etc.

Hardware, Tools, Typewriters.

\section{EXHIBITORS.}

American Automatic Fan Co., Richmond, Va. Automatic sewing machine fans. $0-\mathbf{3 9}$. American Bufralo Robe Co., 1
Howell St., Bufialo, N. Y. Robes.
American Enamelea Brick \& Tle Co., 1 Madlson Ave., New York, N. Y. In Electricity Bidg.

American Metile Co, 112 No. 12th St., Phlladelphla, Pa. Enameled metal tiling. Q-44. 
American Net of Twine Co." 03 Commercial St., Boston, Mass. Flsh nets, etc. $Q-20$.

Amerlean Woolen Co., The, 74 and 76 Worth St., New York, N, Y. Worsted and woolen cloths. Manufacturers of worsted and woolen cloths, overcoatings, cloakings, etc., also worsted yarns of every description. Chas. B. Newhall, Pan-American representative. J-22.

American Wringer Co., 09 Chanber St., New York. Clothes wringers, etc. $S-49$.

Ames Bonner Co., Toledo, Ohio. Brushes. $\mathrm{L}-49$.

Amory, Browne e Co., Hoston, Mass. Cotton goods. $S-22$.

Arington Milis, Boston, Mass. Dress goods. Q-22.

Artiatic Glass Painting Co., Cinclnuatl, $O$. Staincd glass wlndows. $0-33$.

Arure Mining Co., 172 Brondway, New York, N. Y. Jewelry. D-35.

Babhitt, B. T., 82 Wrahington St., New York, N. Y. Soap. M-45.

Balley Co., The, Detroit, Mich. Noveltles in terra cotta. Q-48.

Bannigan Rubber Co., care of R. Rice, 204 Maln St. Buffalo, N. Y. Boots and shoes. J-44.

Barber Jewelry Co., Ner York, N. Y. Jewelry. Q-51.

Belaing Bros., 465 and 457 Brondway, New York. Manufacturers of the celebrated New Process Art Embroidery Sllks; Prize Medal Machlne Twlst; Sewlng, Crochet and Purse Sllks; also Satlns, Surabs, Serges and Mervellleux. $\mathrm{N}-42$.

Berry Bron., Detrolt, Mich. Varnishes. $R-35$.

Birse Sona Co., M. H., Buffalo, N. Y. Paper hanglngs. In Misslon Bidg., north of Dalry Bldg.

Biamell Carpet Sweeper Co., 103 Chambers St., N. Y. Carpet sweepers. $S-48$.

Blake \& Co., Charles G., 720 Women's Temple, Chlcago, Ill. Monuments. $Q-49$.

Alickennderfer Mfg. Co., Stantord, Conn. Typewriters. K-44.

Bifw \& Co., A. H., North Attleboro, Mass. Chaln machines. S-21.

Bommer Brom., 257 Classon Ave., Brooklyn, N. Y. Spring hinges. M-5i. Brady, Mism Florence, 60 r Macon Gt., Brooklyn, N. Y. Embroldery.
Arainera \& Armstrong, Nen b catler don, Conn. Spool sllk, etc. O- Lo catler

rridgeport Gan Implement oenais 313 Broadway, N. Y. Goit clubg e Squar
P-20.

Bridgeport Wood Fintuhing Dengmo New Milford, Conn. Palnt, etc a

Brunatvick-Balke-Collender allot 84 Pearl St., Buffalo, Blllard ?
bles. L-28. Buck Bros., Millbury, Mass, Tool Enter
etc. P-5i.

Bufinlo Mfg. Co., 444 Niagan H., Buffalo, N. Y. Water filters. Eater

Bufalo oil, Paint \& Yarnle deb 1317 Fll St., Bufralo, N. Y. Oll, pe and varnlsh. $\mathrm{O}-37$.

Dufialo Senie Co., Buffalo, seq Scales. R-38.

Buttericlc Publishing 13th St., New York. Paper pattem S-25.

Cary Safe Co., Buffalo, $X_{\text {, }}$ Safes, etc. $\$-47$.

Crasidy \& Son Mfg: Co., 133 $23 d$ St., New York, N. Y. In Elentel lty Bldg.

Cuttaraugus Catlery Co., Ut Valley, N. Y. Cutlery. J-49.

Century Corset Co., New Have Fr Conu. Corsets. R-40.

Chamberlain Metal WeatherStr Fr Co., Detrolt, Mich. Weatber sthly II -48 .

Chase \& Co., L. C., 129 Washing ton St.. Boston, Mass. Plush good L-23.

Mohair plushes and artificial leathe Manufacturers of goat brand mobri car and furniture plush. Chase an flclal leather for all linds of ugbol stery work. Three horse bead hoi blankets and carriage robes.

Chicago Writing Machine $c_{0}$. Chlcago, Ill. Typewriters. S-48. "The Chicrgo" typewriter is masute: tured by the Chlcago Writing yls chine Co. of Chlcago. It is the t5pe wrlter which combines maximum quis ity with mlnlmum prices.

Clark \& Co., Geo. M., Chicago, II Gas stoves. $\mathrm{P}-49$.

Colnmbia Trpewriter Co., Ке York Clty. Typewriters. N-48.

Corbin Cabinet Lock Co., New Br. taln, Conn. Locks, keys, etc. K-48

Crompton Co., Providence, $\boldsymbol{R}, l$ Corduroys. 8-21. 
en hy cutler and Son, A., Bufralo, N. Y. Cutier aniture. K-25.

Denuison MPg. Co., 301 Ellicott Square, Buffalo, N. Y. Tags, etc. $S-40$.

Densmore Typewiter. See United Typewriter \& supplies Co.'s exhlbit. K-49. Ellott Addrensing Machine Co., 100 Purchase St., Boston, Mass. Addressing machines. S-40.

Euterprise Mfe. Co., of Pa., Philadelphla, Pa. Hardware. $K-49$.

Erlekson Artificial Limb Co., E. H., Minneapolls, Minn. M-28.

Eaterbrook Steel Peu Co., Camden, N. J. Pens. All visltors should see this handsome exhlbit of the พorld-renowned Esterbrook Pensembracing every variety to meet the regulrements of all writers. $\mathbf{J}-51$.

Fireproofine MPg. Co., New York. Elreproof materlal. Fireproofine, the only perfect fireproofing solution in exlstence. All woods and any fabrics rendered absolutely fireproof without the sllghteat Injury to color or texture. $x-41$.

Fleisher, S. B. at 1. W., Incorpornted, Phlladelphia, Pa. Manufacturers of the celebrated Flelsher's Worsted and woolen yarns, especlally adapted for knltting purposes ; also Worsted bralds of all kinds and widths. $M-23$.

Frlnk, J. B., New York, N. Y. Tefectorg in Transportation Building.

Fullayter Keen, Bufialo, N. $Y$. Dress goods. $0-22$.

Gardner, Mrs. Mary A., Miami, Wla., Jewelry.

Garnex \& Co., New York City. Textlles, sllks. $0-22$.

Gem Cutlery Co., New York, N, Y. Safety razor's.

Globe Woolen Co., 37t Broadway, N. Y. Woolen cloths. N-22.

Graud Rapids Chair Co., Grand Raplds, Mich. Settees and tables in Afichigan State Bullding.

Grand Itapids Clock and Mantle Co., Grand Raplds, Mich. Colonlal Clock in Mlchlgas state Bullding.

Gransell Chemical Co., The, main office, Cleveland, Ohlo. Chemlcals. Manutacturers of "Commerclal" and "Chemically Pure" chemicals. Principal factorles located at Cleveland, Ohlo; New York, N. Y. : East Chicago, Ind.; Bl rmingham, Ala. : Beaver Falis, $\mathrm{Pa}_{\text {. ; }}$ and Titusville, Pa. Sales branches at Clnclnnatl, Ohlo ; St. Louls, Mo. : Mllwaukee, Wis. ; St. Paul, Mlun, ; and New Orleans, La. M-48.
Hanan a Son, Brooklyu, N. Y. Boots and shoes. R-26.

Harding, Whitman \& Co., Bonton, Mass. Cotton yarns. $R-22$.

Hart, Wm. W., 47 E 12th st., N. $Y$. City. Furs and skins. Q-40.

Inrtshorn Co., Stewart E.. Newark, N. J. Shade rollers. P-47.

Iavana Commercial Co., 145 Broadway, N. Y. Clgars. P-35.

Heinigke \& Bowen, New York. N. Y. Stained glass windows. $\mathrm{O}-33$.

Heller \& Merz Co., 55 Malden Iane, New York, N. Y. Coal tar colors, etc. $0-42$.

Herper Bros., Newark, N. J. Jewelry. $\quad P-51$.

Herrick o Co., G. W., Lyun, Mass, Boots and shoes. $0-30$.

Hiblorad-Rodman-Ely Safe Co.. New York, N, Y. Exhiblt in Mrlues Bullding.

Hoefner, Anseln, Bufialo, N. Y. Soaps. $K-46$.

Iyde Fountuin Co., Rochester, $N$. Y. In four corners of bullding.

Hovrard Clock Co., E., Bonton, Mass. Tower clocks. $p-51$.

Idenl Cash Reyister Co., Bound Brook, N. J., Buffalo, N. Y. Cash reglsters. $J-47$.

Independent Cordage Co., Torouto, Ont. Cords, etc. $R-42$.

Ironclad Mrg. Co., New York, N. Y. Enameled ware. P-26.

Kampfe Bros., 8-12 Rende St., New York City. Safety razors. $0-40$.

Krahu Talloring Co., Cor. Mexiden and Washington Sts., Indianapolls, Ind. Garments. $M-26$.

IFeck, Ilenry, New York, N. Y. Stained glass windows. $0-83$.

Kellogk, Spencer, Bufralo, N. Y. Linseed oll, $Q-26$.

Kochs Co., Theo. A., Chicago, I11. Barber's' chairs. Q $Q-40$.

Korn Mras. Co., Geo. W., Little Valley, N. Y. Razors. J-40.

Lamb, J. \& $R$, New York, N. $Y$. Stalned glass articles. In Misslon Bldg., north of Dalry Bldg.

Lambert Typewriter Co., 253 Broadway, N. Y. Typewriters. S-42.

Laird, Schober Co., 19th \& Buttonwood Sts., Pbiladelphla, $\mathrm{Pa}$. Shoes. S-32.

Larkin Soap Co., Buffalo, N, Y. (Outdoor Blds.) 
Gong, Alelatie Ir.. New York, N. Y. Stained glass windows. $0-33$.

corilnmi lefrigerator Co., New York, N. Y. Refrigerators. In N. Y. State Bidg.

Lorraine Mfer. Co., 53 Leonari St., N. Y., Pawtucket, R. I. Dress goods. li-23.

Los Angeles Axt Ienther Co., Los Angeles, Cal. Art ieather. D-33.

Lutfy \& Macksour, \& Carilsle St., New York. Art needle work etc. N-28.

Arnloney Bros., Rochester, N. Y. Shoes. $Q-30$.

Manmion, J. J., Iufralo, N. Y. O1tical goods. $\quad I^{\prime}-14$.

ranville Co., Bonra of Tratle Bldg., Lrovidence, R. I. Uress goods. I -22 .

Macey Co., Whe Fred, Grand InpIds, Mich. Bookcases. $R-31$.

Marics Adjustable Folding Clunir Co., 1140 Broadway, N. Y. Folding chairs. $\mathrm{R}-41$.

Manrer, Henry \& Son, New York, N. Y. Terra cotta arches. Outdoor space, near Canada Building.

Maydole Iammer Co., David, Nomwich, N. Y. Steel hammers. O-39.

McCullnm Silk Co., Nouth Hawpton, Mass. Silk hosiery. G-32.

MeDowell Garment Drafting Co., 6 W. 14 th St., New York, N. Y. Dress making. $R-20$.

MeIIng?口 \& Co., Joseph P., 3 W. $42 d$ St.. New York, N. Y. Artistic furniture and hangings. in $N$. $Y$. State Bldg.

Mertu Soms, Geo., Port Chester, N. $\mathrm{Y}$. Wood monldings. S-23.

Murer Senting Co., Cauml Dover, Ohio. Stoois, tables, etc. $0-51$.

Michigan Chair Co.. Grand Rapids, Mich. Mahogany chairs, Michlgan State Building.

Michigan Store Co., Detrolt, Mich. Stoves. $\mathrm{S}-44$.

Mosale Tile Co., Zanesville, Ohlo. llinols State Building.

Mniler \& Slucle, Grand Rapils, Mlch. Divan and chairs in Michlgan State Bulliding.

Irusxy Bros., Paterson, N. 3. Colorea water paints. $\mathrm{S}-26$.

National Broume and Buss Co., 25 IV. Broadway, New York, N. Y. Ornaments. $0-40$.

Natiomal Cash Legister Co., Dnyton, Ohlo. Cash registers. O-33.

Nelson, Iratter Iruruiture Co., Grand
Rapids, Mich. Desk in IItchigan
Buiding.

New Century Callgraph Typeriti
See United Trpewriter See United Typewriter \& Supplien (it
exhibit. K-49.

New Domestic Sewing Machl
Co., New Yolk, N. Y. Sew Co., New Yolk, N. Y. Newing
chines. I - 14.

New Fork Nills, New York mil N. Y. Oneida Co. Cotton goods $0-$ th

Nineteen Hundred Washer Biughamton N. Y. Washing machine
N-47.

Nomotncle Silk Co., Florence, Ju
Silks. Nompareil Cork Mfg. Co., Bridgepor
Colnn. Laid floor. U-28.

Nortinela Innife Co., Northte Conn. Pocket knives. $0-51$.

Northwestern Grass Twine a 204 Van Brunt St., Chicago. Trina etc. $J-25$.

Ohio Tool Co., Columbas, 0h Hand tools. $\mathrm{N}-51$.

Oliver Rros. Co., Lockport, $\mathrm{S}_{\text {, }}$ Brass and iron beds. $R-43$.

Oliver Typewriter Co., 263 Broal way, New York, N. Y. Typewrite $\mathrm{M}-47$.

Oneida Community Lta., Nagm Falls, N. Y., and Kienwood, N. Y. Ho ware, silverware, etc. $15-49$.

Oussani Yak, New York, $\mathrm{X}$, Cigarettes. $\mathrm{N}-44$.

Oxpora Mfe. Co., Oxford, Nova Se. tia. Homespun and tweeds. $S-4$.

Oxley E Enos MIfg. Co., New York N. Y. (N. Y. State Bidg.) Hangin fixtures for elcctric lighting.

PnImer, Isnac E., Middletom Conn. Loom. S-28.

Manufacturers of Paimer's Pertection Arawana, Utopia, and Solitalre Haz mocks; Supports; Trapeze Bars; tifriction Hitch Hooks for Bqu mocks; Minnow Nets, and Horse tings.

Pantasote Co., The, 29 Brondwa N. Y. Leather substitutes. R-42.

Peace Dale Mfg. Co., Peace Dalt R. I. Cloth rugs, etc. $M-22$.

Phoenix Furniture Co., Grand Ra. pids, Mich. In Michigan State Buill ing. Furniture.

Pike Mrs. Co., Pike Station, N. H Sharpening stones. $\mathrm{R}-47$.

Olistones, scythestones, grindstones razor hones, emery and corundur stones and wheels. polishing powders etc. World's headquarters for shary ening and grindiug stones and material of all kinds and for all purposes. Golh medal, Paris, 1900. 
Pitshnrg PInte Glass Co., Juison and Van Dam Sts., New York, N. $Y$. Glass. $\mathrm{S}-37$.

vituluarg Rediction Co.. Ningarn Falis, N. $\mathrm{Y}$. Aluminum. J-4G.

plant, Thos. G., Center d Bickford Sts., Boston, Mass. Shoes. S-2J.

pratt d Letchrorti, nunalo, $N$. $X$. Jalieable Iron, etc. $\mathrm{O}-49$.

Pugi Bros. Statuary.

R. \& G. Corset Co., 361 Bromavay, Y. Y. Corsets. S-47.

Regnl Textile Co., Utica, N. Y. Knit underwear. $\mathrm{I}-31$.

Rerlilon Freres, 13-15 W. 28th St. New York, N. T. Furs. IR-21. Importers, exporters, manufacturers of high ciass nuvelties and staple goods in fur and fur-lined garments. Members of jury at Paris Exposition. 1900. Hols concours (beyond compe. tition).

Rockirell f Rupel Co.. Clicago, III. Pan-American office furniture.

Robinson Fur Co., Bufrato, N. $Y$. Fuis, $0-36$.

Rodrlgues, Salvador, New Yorlí, I. $\mathrm{Y}$. Cigars. $\mathrm{P}-3$ 5.

Roesslex d Hasslacher CliemienI Co., The, New York. Manufacturing chemlsts. Acetone, Chloroform, Cyanide, Caffeine, Cocaine, Coumariue. Pilocarpine, Ceramic Colors (enamel and underglaze), Liquid Bright Gold, Platinum, Sliver, Sulphur Dioxide, Buratylene, Peroxide of Sodium. $1-40$.

Rome Knitting Co.. IV. IT., F) Frankiln St., New York, N. Y. Knit underwear. $\mathrm{O}-23$.

Ruszits Frx Comprny, ToIn, 73-75 Jercer St., New York. liurs, skins, etc. A complete stocli of the kuszlts furs can be seen at flint \& Kent's, 554-562 Main St., Buffalo, where all orders for present or future delivery Fill receive careful attention. $I_{-} 22$.

Sanchey d Hayn, Netv York, $N$. Y. Cigars. P-35.

Sehoelliopf, Hnrtford \& Hnnna Co., Buffalo, N. Y. Chemicals. R-49.

Senbury \& Johnson, Iniden Lnic, New York. Surgical instruments. Q-41.

Shantz de Co.. M. M., Rocliester, N. I. Buttons. K-25.

SInger Sewing Machine Co.. Nevr York, N. Y. Embroidery. J-31.

Sinde d Hiclis, CIileaso, I11. Paper. $\mathrm{M}-24$.
Gniti Premier 'Tyneviter Co. Syxicuse, N. I. Typewriters. IR-4i.

Standand Paint Co., 83 bohn Sí. New York City. Tuints, freproof materials. Separate building, north of Giange Iidg.

ctandisil zorster Co., The, Flymouth, Mass. Iligh grade cloth. N-2?.

Stunley Wonlis, Nes Fritain, Conn. Haruwure. $0-19$.

Stern Rros. de Co., 69 Naksntr St., New York, N. X. Diamond cuttins. IL-33.

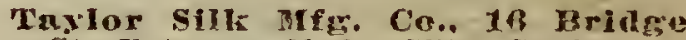
St., Paterson, N. J. Sllk. S-31.

roda. Hanchoft of Co., Horkester, N. Y. Hoots and shues. $Q-33$.

Union Bug \& Paper Co., Fisluer lijag., Chicago, Ill. Paper bags, etc. $\mathrm{S}-27$.

United Slzoe Mrachinery Go., Albany Bldg., New Iork, N. Y. Sluoe machines. $\mathrm{Q}-30$.

United 'Tspewiter mul Supplies Company, 316 Broadway, New Sork, N. Y. Standard typewriters and supplies. Ir- 49 .

United Pyperifriter and Sapply Co., 21 Niagara St., Buffalo, N. $Y$. Typewriters. $\mathrm{M}-45$.

Wngner Irfg. Co., Sianey, Olilo. Iron hollow ware. $\mathrm{S}-40$.

Wnginex Typewriter Co.g 220 Mroadifay, jew Iork, N. Y. Tspewriters. $\mathrm{Q}-42$.

Wanslarcla Mills Co., Proridence, Il. I. Textiles, etc. 1 '-23.

Waterinan Forntain Pen Co., I. I.. New York, N. $Y$. Fountain I'ens. $\mathrm{S}-42$.

Weingrater Brow. New Tork, Y. Corsets. L_- 66 .

Nos. 377 and 379 Broadway, New York Corsets. "ry. B." and "Ia Vida" corsets. The largest corset manufacturers in the world.

Wemple Co., J. C., New Tork, N. $Y$. Window shades. S-24.

Whitelienil of Honf, Cor. Wash. \& Warren St.s., New York, N. Y. Badges, etc. $\mathrm{R}-28$.

wlitman \& Co.. Clarenee, 39 Lconald St. New York, N. Y. Textiles. line white cotton diess goods. plain and fancy weaves. "Nottingham piain, and curtains and nets. Bed spreads, wbite and colored hemmed and fringed. J -20 .

Williams Co., J. B., Glastonbury, Conn. Soaps. Q $\mathrm{Q}-40$. 
Willinnis Mfg. Co., 'The, I,til., Montreal, Canade, and Plartsburg, N. Y., Wellington No. 2 Typewriter. N.

wilke Mfg. Co., Anderson, Ind. Refrigerators. $Q-45$.

Wirt, Panl F., Bloomubnrg, Pa. Fountain pens. $0-25$.

Wood Mosalc Co., care of George A. Stevens, 575 Ellicott Sa., Bufalo, N. Y. Parquette floor. $s-38$.

Wyckor, Seamann \& Benedict, New York, N. Y. Remington Standard Typewriter. J-26.

The reeognized standard of the world. Recent International Expositions awarded Grand Prize (highest award)

Brussels, 1897 ; Diploma of Honor (highest award) Iixxembourg, 1898 , Ghent, 1899 ; Grand Prize, Parl's, 1900.

Tost Typowriter. Seo United Typewriter \& Supplles Co.'s exhlbit. K $K-49$.

\section{MEXICO.}

Aboltis, Manuel, Salamanca, Guanojuato. Gioves.

Acosta, simon, Tulanclngo, Hidalgo. Scaies.

Agnilar, Angela, Pachuca, Hidalgo. Embroldery.

Alupurd, Alberto, Mexico. Tollet artlcles. D-F.

Alarcon, Flliberto, Huaralingo, Hidalgo. Cirars.

Aleman, Fernanilo, Morelia, M1choacan. Drugs.

Arozn, A., Teoloynca, Mexico. Cushione.

Arringa, Jonquin, Morelin, Mtchoacan. Clgarettes.

Avila, Anselmo, E. HAjo, Mexico. Toliet artlcles. $\mathrm{D}-\mathrm{F}$.

Aviles. Manuel, Salamanca, Guanofuato. Gloves.

Arantamiento de Tequixquidpan, Querataro. Chairs.

Berragan, Maria, Zacatecas. Embroldered bandkerchlef.

Barragan, Sebastian, Santa Ana Chiautempan, I'laxcala. Woolen zarapes.

Basallo, Vicente, Mexico, Pharmaceutlcal products. D-F. Belma, Hermanos, Veracrux. Ci-
gars.

Bueno Barroso Arias, L.. Tajimaroa, Mlchoacan. Cotton goods.

Burgas, Senoritas, Queretnro. Embroldered baudkerchleis.

Bustillos, Jose E., Mexlco. Ches
cal products. D-F.

Corandente, F., Taenbara, Bro
statue. D Carrasco, Vicente, Otumba, It
lco. Syrup baisam.

Carrillo, Franclsca, Ganarjow Embroldered handkerchiefs and rell

Cranx, D., San Juan Bauth

Castanos, Gunialnpe, shaw Sinaloa. Embroldery. Marathl cobles

Carares, N., Otruba, raral Pharmaceutical products, Mertal Goble

Chambon, Hipolito, Yexil Haw can silks and shawls. D-F, Merd Gome

Coeto, Mannel, Pueble. Clot glass.

Colegto de Santa Terene, Gonz Mexico. Embroldery.

Comminsion of Parasito gons Mexico. Chemlcals and drugs

Compania Cignrrera Merich cions Mexico. Clgars and cigarettes, $D-i$.

Compania Induatrinl ile Oriabl Veracruz. Cotton goods.

Compania Industrial Mnnufactu. era de Monterey, Nuevo Leon. Thla

Compania Manufretnra de Orlu. ba, Veracruz. Jute goods.

Companta Mexicana Manufactun San Manuel. Fiazcala. Cotton 80 l and musllns.

Cornu, Pedro, Agnascallenter Casslmeres.

Corvera y Corona, Guadaiajum Jalisco. Pharmaceutical products

Dellus y Compania, Ixtapa Cor cepcion, Tepic. Cigars.

Dominguex, Sinforiano, Comitur Chiapas. Bed cover.

Elle, Panl, Mexico. Drngn, D $f$, Elle, Panl, Mexieo. Square. D-P

Espinown, Fellx M., Mexico. Medl cinal products. $\mathrm{D}-\mathrm{F}$.

Evia, Jowe Maria, Campeche, $\mathrm{Cr}$. arettes.

Fernander, Juana, Zacateca, Foot cover.

Fletes, Amado, Tepic. Clgars.

Flenry, Enriqueta E. De, Mexied. Embroldery.

Galvan de Lostroes, Jowela, Mex. ico. Busts. D-F.

Garcla, Enteban, Colima. Clgan

Garcla, Maria, Mexico. Vereen D-F. tar

Gae?

Lul

Gult

MI

Her

D

Hin

(3)

10?

Hu

III

J日

Je

J

J 
Garcla, Martin, Tulancingo, Mexlco, Cotton and woolen goods.

Garsa, Juana De La, Guerrero, Tamaulipas. Counterpane.

Garsa, Lorenzo de lo, Ciadad Victoria, Tamaulidas. Qullt.

Goblerno de Durango. Carpets.

(ioblerno de Dnrango. Casatmeres.

Gobierno de Znentecax. Mexican shawls (rebozoz).

Goblerno de Zncatecas. Woolen zarapes.

Gobterno de Yucatan, Merida. Hammock.

Gomex, Pledad, Guanajunto.

Cloth.

Gomex, Rita, Collua. Napkin.

Gonzalez, Hernanos, Sun Juan Bautlsta. Tabasco. Clgars.

Gonzalez, Eusebio, Gunnajuato. Casslmeres.

Gonalez, Gregorfo, Merida, Yucntan. Clgars and clgarettes.

Guerrero, Ignaclo, A. HiJos, San Luis Potosi. Mexican shawls (rebozoz).

Gutard, Enrique, Zirisienaro, Mlchoacan. Ceramle goods.

Herminia, Charles, Contulla. Drawn llnen work.

Hinojonn, Josefina, Mexico. Screen. D-F.

Holek, C. y Compania, Monterrey, Nuevo Leon. Matches.

Hurtado, Maria, $Z$ cntecaw. Foot cover.

Inla, Aurelia, Zacatecas, Handkerchlet.

Jacquen, s. \& J., Celaya, Guanajuato. Undershlrts.

Janpeado, Rnperto, Texcoco, Mexlco. Sllks, fabrlcs.

Journel, Marin, Zacatecan. Bnreau cover.

Juambelx, Hermanon, Sucenores, Durango. Woolen goods.

Junta de Senorns, Cuernavaca, Morelos. Pllow case, embroldered gullt.

Junta Local de Puebla, Puebia. Bat.

Junta Local de Pueblo, Pueblo. Bust In bronze.

L. Tajimaroa Bueno Barrowo Arlas, Mlchoacan. Cotton fabrics.

"La Concordia" Fabrica, Chihuahua. Blankets and casslmeres.
La Induntrial (Socledad Anonima) Merida Yucatan. Hemp goods.

Lanxagorta Hermanos, San Blan, Tepic. Clgars.

"Ia Pax" Gran Fabrica de ropa (Socledad Anonlma), Chlbuahua. Men's shirts.

"La Paz," Socledad Auonima, Chlhuahua. Counterpane.

Las*o de In Vera, J. M., Mexico. Febrifuge, $\mathrm{D}-\mathrm{F}$.

Leon, Juan, 'Texcoco, Mexico. Canslmeres.

Leyarikh, Jone, Leon, Guamajunto. I,eather goods.

Lon, Engenia, Agnascallenten. Drawn llnen work.

Llerena, Tecla, Collma. Napkin.

Lopez, Felfpa, Mocorito, Sinaloa. Vell.

I.ncarra, Cmilia, Hermoailio, Senora. Drawn llnen work.

Madrazo y Corrales, Veracruz. Clgars.

Main, Iremanos, Monterey, Nuero Leon. Hats.

Marnnt, Paul, Mexico, Cnfu, collars and shirts. D-F.

Mestan, Anawtaio, Mexico, Brase beds. $D-F$.

Moebinx. Guido, Monterey, Nuevo Leon. Matches, candles.

Moreno, Romulo, Valle de Sant1ago, Guanajuato. Clgarettes.

Morentin, Paulo, Colima. Napkin.

Moran, Antonio, Agnasealientew. Clgars and cigarettes.

Morgado, Maria, Zucatecan. "Schachet."

Navarro, Juan, Mexico. Hrame Bed. D-E.

Nieto (Jose de Jesns) E. Hijo, Puebla. Gold and silver trimmlngs.

Noncio, Mixu Gertrudis, Mexico. Drawn llnen Work. $\mathrm{D}-\mathrm{F}$.

Nunclo, Miss Otilia, Mexico. Drawn llnen work. D-E.

Ollivier, D. y Compania, Flanapantla, Mexlco. Percale goods.

Ontiveron, Plediad, Gunnafuato. Embroldery.

Penitenciaria Del Eatado de Nuevo Leon, Monterey. A comb.

Penitenciaria del Emado de Nuevo Leon, Monterey. Baskets, purseg.

Penftenclaria del Estado de Nuevo Leon, Monterey. Collars. 
Peren, Reguera Luis, Oaxana, Cizarettes.

Plicgo, Mermanos, Toluen, Mexico. Cotton fabrics.

Ramires, Jose G., Villa Alta, Oaxaca. Pita hammock.

Ramos, Concepeion, oaxaca. Cushion.

Ramos, Evaristo, Mrorelia, Michoacan. Shoes.

Reyes, Manuel Daron, Ayuas Galientes. Cissimeres and woolens.

Reyes, Senoritn Carimen, Puebla. fiancy articles.

Rivera, Manuicio, Mexico. Shoc lasts. $\mathrm{D}-\mathrm{F}$.

Rivero, Valentin, Sncesores, Nuevo Leor. Cotton goods.

Fobledo, Euioia, Nrocarito, Simaloa. Hook weaved napkin.

Robien, Francisco, Colima. Cigar's.

Rodriguez Samano, Francisco, Mrorelia, Michoacan. Cigarettes.

rlosarlo, Desiderio G.. Comalcaico, Tabasco. Medicinal products.

"Snint Mranel River Fa:1," Fabrica. Tlaxcala. Cotton goods.

Salas Ierrexo, Ismael. San Luis Potosi. Wooden mosalc furniture.

Sanchey, Carmen, Truxtia Gritierrez Chiapas. Weavlng hook.

"San Ihefonse" (sociedad AnonIra), Flanepantla, Mexico. Carpets and mats.
"San Idefonse" (nocledal doon ma), Manepantla, Merico. Ho

"Santa Gertrudis" Compania ufacturera be Yute, Orizabs, Verace Jute goods.

Snutos, Inafael, Zaeatian, Pael collec Mexican shawls (rebozoz). Paetl collen men

Silra de Grticrrez, otilia, 1 gu Lifn calientes. Drann linen work. clave clilia

Solls. Dario J., Otrimba, Meril man, Liedicinal products.

stiker, valentin, yerb Agua scalieutes. Carnets.

Sunrez, Edaarilo, Texcoco, Mextr Woolen zarapes.

Tolsa, Manuel C., Hexico. Itent can onys goods. D-F.

Yazrues, Cipriano, Mtantlan, sh aloa. Cigars.

Vaznuer, Monico, Valle de trats Mexico. Silk sleins.

Von Gehren, Edmundo, zacatew Birch furniture.

Villa Hermanos, Sucesores, Orin ba, Veracruz. Cigarettes.

Villada de la Pena, Guadalap Toluca, Mexico. Embroldery, mu触

Zavala, Francisco, Puebla. Chain Zenlwo, Christolual, Puebla, Shoeh Zolly, Hermanos, Mexico. Hat D-F.

Zorilla, J. y Cempania, Oaxace Cotton fabrics. 


\section{INTERIOR COURT EXHIBITORS.}

\section{Art Manufactures.}

Collective Isxlibit of Bntralo Women's work. Arts and craft.

Lina Fuldner, Minerva P. rytie, Giulla Regoll, Sara Hadley, Llzzie Heeman, Jennle M. Hayden, Edith Sterling Nichols, Mrs. E. O'Donnell, Hannah M. Herbert, Mrs. E. L. Humphrey, Miss Matilda Mlddieton, Miss Elorence Hart Winer, Mrs. IeRoy T. Steward, Mrs. .I. B. McCrystle, Miss Helen M. Topping, Miss Mary A. Phillips, Mrs. F. M. Sessions, Miss Eva E. Adams, Mrs. A. $\Lambda$. Frazee, Mrs. B. I. Frazer, Miss Mary Alden, Mrs. Henrietta 1 . Zeublin, Mlss Grace H. Peck, Miss Mabel C. Dibble, siss Lllie E. Cole, Mrs. R. S. Balley, Mrs. W. W. Foggo, Mrs. W. H. Klapp, Miss Amy C. Townsend, Mrs .Sarah Weber, Mary Lawrence, Mrrs. Thomas Henning, Miss Emma D. Dakin, Mrs. C. F. Rlchert, Mrs. George C. King, Mlss L. Garretson, Miss Ella Newton, MIss E. Grace Mllsom, Mrs. Mary West Stickney, Irs. Mary A. Clarke, Mrs. Ella is' Coombs, Mrs. Kate Wildemuth, Miss Minnje Beamer, Mrs. Allen E. Day, Mrs. Sarah B. Scott, Anna A. Thompson, Mrs. Frank J. Shuler, Miss Char.otte Pendieton, Mrs. L. W. Ross, Mrs. May Hundiy Bowly, Josephine Klippart, Herminia Davila, Augustina T. Zumbado, Mrs. Grace Huntlngton Buckland, Laura C. Wiley, Mrs. A. J. Halnes, Mrs, Dorothea Frledman, Florence C. Davis, Mrs. J. $\Lambda$. Hail, Henrletta C. Schuetz.

Copper Queen Consolianted MinIng Co., New York, N. Y. Copper and brass goods.

Catler Girard, New Yorle, N. $Y$. Art furniture. $\mathrm{M}-25$.

Drake Co., The, St. Paut, Minn. Petrified wood table tops.

Gorhnm Mfg. Co., New York, N. Y. Silverware. G-37.

Grneby-Faience Co., Boston, Mnas. Pottery.

Nitional Art Cinb, 37 W. 23i St., New York, N. Y. Collective exhibit, arts and craft.

National Fine Arts Foundry, 218 1. 25th St., New York, N. Y. Statues In bronze.

Nationnl League of Minernl Painters. Decorated ehina and pottery.

Rohlfs. Charles, Aunalo, N. Y. Art furniture.

Rookwood Potteries, Cincinnnti, Ohlo. Pottery.
Singer Mrg. Co, New York, N. $i$. Embroidery.

Sioane, W. E I.. Brondway and 19th St., New York. House furnishIngs, imported and domestic carpets and rugs, upholgtery, classic furnlture, decorations. Wistablished 1843 , New York and San Franclsco.G- 99.

Stickley, Gustaye, Syracuse, N. Y. Fancy wood and leather work.

Tifinny Studios, Nier Foul. N. $\mathbf{Y}$. Favrile and other glass $\mathrm{I}-39$.

rifnny t Co., New Yorgh, N. $Y$. Jewelry, etc.

\section{NATIONAL ART CLUB EXHIBITORS.}

Ainsley, Oîver, 030 Sth Ave, Ners York City. Design for glass window. Albee, Mrs. John, Providence Axt Club, Providence, $R$. I. Rugs.

Amsden, Hnxiet, 105 E. 17th St., New York Clty. Pillow cover, copper bowl.

Andrews, Hariet W., 110 I. 231 St., New York City. Panel.

Artist Frederic indennies. Bnechante, Boy and Heron, Venus and Adonis, Runnlng Cupld, large Shakespeare.

Artist Menry M. Sirady. BuraIo, Moose.

Artist Max Bachmann. Nust, fann, Bust, Indian.

Artist Irs. Clio Brncken. Lotus Flower, figure, the Pearl, dancing figure, statuette, danclng tigure, sea Nymph, figure, the Wave.

Artist Bessic Potter. Group tzic Nother, figure dancing girls.

Artist H. Linduer. Pair nudirong, the Rlowers, Bust, Morning; Bust, Evening.

Artist limston Perrs. Bromme, Llon in Love.

Artist MacDonala. Bust, Washington.

Artist Storeli. Walking lion.

Artist Wolfram. Elephnnt.

Aniley, Corat, 33 InGrange st.; Boston, Mass. Mosaic window. 
Barnard, Min Jonephine Ways, 25 W. 34th St., New York City. Embroldery.

\section{Baylor, L. Drawing*.}

Bencon, Mrs. Mine, 2 W . 34tl St., New York City. Designs on silk, llnen cotton, paper, etc.

Berea Collese, Beren, KY. Table cover, frame of photographs.

Bieracli, S. Jr., 248 Finton St., Brooklyn, N. Y. Frame book cover.

Blackmore, Arthur C. Pnnel, photographs, etc.

Boone, C. I., Montclair, N. I. Deslgn candlestlck.

Aowcomb, Jemmle, 7 W. 28 th St., New York CIty. Deslgn for mural palnting.

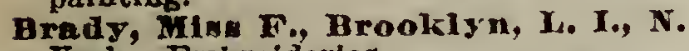
York. Embrolderles.

Arown, Harold H., 60 W. 13th St., New York Clty. Book cover deslgns.

Brovin, Weed. Painting.

Brownin, Mnry R.* 49 Garden Place, Brooklyn, N. Y. Decorative atudies, silk designs, bookcover designs.

Buckley, W. D. Bookn.

Balger, W., Chicago, I1. Howl and Jars.

Bunh-Hrown, I. I., 107 E. 27th St., New York City. Bronze statues.

Busclk Stualok, 29 E. 20 th St., $N_{\text {. }}$ Iork Clts. Copper plaque.

Batterworth, Mrs. Menry, 939 8th Ave., New York City. Letter boz.

Clarike, Thos. S., 50 Rirerside Drive, New York City. Andirons.

Clintor, H. Jennie, Ridgewood, $N$. J. Book cover design.

Coekcroft, Gavard T., 369 sth Ave., New York Clty. Design for fire screen.

Cornwell, Martia J., 162 W. 67 th St., New York Clty. Photographs.

Crouch, Ih. Wair, if bth Ave, New York City. Clock face.

Crownfeld, Mrs. Davia, 111 Tremont Bldg., New York City. Wax models.

Curtin, Mr., 10 W. 30th St, New New York City. Burned wood, chest screen, panels.

DeMarewt, Min Florence, 7 E. 15th St., New Iork Clty. Terracotta jars.

Denbs, Edwin I., 8 F. 31nt St., New York CIty. Plctures.

The Deerfeld soc of Blue nid White Needlework, Deerfield, Mass. irats, table covers.

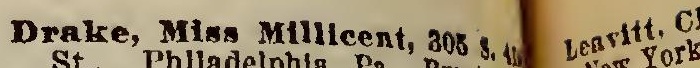
St., Phlladelphia, Pa. Burnt in Lers Nork
chest. Drennan, Mins Eunlce, Tesches Lens, Mif
College, New York City. Curtah,

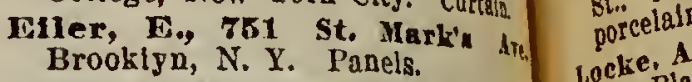

Gppemilor, Lina, 103 Adelph Brookiyn, N. Y. Straw baskets.

Tle Evelyn Nordhof Bindery, D. 23a St., New York City. Leth curtaln.

Forbes, Miss Inrriet Kieth, negle Hall, New York City. Pals bellows, tras, portfollo, jug.

Fonilek, J. William, 24 E, 28 St., New York Clty. Large pant? Joan of Arc.

Forler, Cariton C., 72 W. 45 th New York Clty. Design lor maguts cover.

Francis, Mise Sarnh, 132 s. St., New Iork City. Grass woth bet kets.

Frank11n, I. F., 30 Central Port Soutb, New York City. Book cork

French, Idwin D., Saranac lakt N. $\mathbf{X}$. Design of book plates.

Froelteh, Ingo, 208 Washingto Are,. Brookign, X. Y. Oak mirm frame wlth attached amall cabiat tray burnt and stained wood, fet: cagket.

Fry, Marshall, 36 W. 24th St, Xen York City. Porcelain vase.

Gotthola, Mrs., New Yorl. Illums nated rólumes. Vellum.

Grueby Faience Co., 2 A Park sh Boston, Mass. Case contalning ow tery vases, percock medallion, cout arms tlle.

Grabenbecker, $H_{*}, 418$ W. 2th St., New York City. Rellels, woodet panels.

Tarley, Chas. R. 145 R. $23 d \mathrm{st}$ New York Clty. Statuettes In broms

Iellet, Mis* I. M., 68 W. 67th st New York Clty. Burnt and cars wood, frame pine, carved and glided table book racks with carved end.

H111, Laura Cowes, 320 Boylen. town St., Boston, Mass. Medalllons.

Taeger, Henry, 146 F. 26th st, New York City. Nural designs.

Joy, Mlss, studio 3 Parle st., Bol. ton, Mass. Punch bowl and stand.

Kellogs, Droisht. Burnt wood, work box, wooden panels, nut bowl.

Krelael, Mrina E.. 196 W. 7th St, New York Clty. Wall pager design. 
8. 14d Learltt, Chas. W., 15 Cortlnndt st., Ner York City. Landscape plctures. Lenz, Alfed. Figure wnx. Leonard, Mrs. Annu B., 28 E. 23d St. New York City. Plate gllded, porcelala gilded chocolate set.

locke, Alexander S., 46 Monturomery Place, Brookign, N. Y. Stalned glass window designs.

Loefier, M., 208 Market St., Newars. N. J. Flower panel, carved in wood; tlower panel, wood carved vase in oak.

Longstretch, Margnret, 033 Sth Ave. New York City. Color deslgn for decoratlon, colored dry polnt.

loomis. Chester, 965 th Are., New York City. Study for window.

MacConnell. Mins Sarah, $226 \mathrm{~W}$. 75 th St., New York City. Framed book cover design.

Mnlone, Blondelle, $46 \mathrm{~W}$. 55th St., New York City. Book covers.

HeHngh, Jos. P., Stlk Ave, and $42 d$ St. New York. The mission work, duet bench, slipper chair, bed chamber chalr, mlssion chiffonler, mlssion tabourette, mlsslon nlght table, mission night lamp.

McKay. Edwin Murray, 105 E. 17th St., New York City. Design, the Haberdasher.

MeVelI, Mrs. H. A. Snmovar.

Morne, fimle, 203 w. 133 a St., New York City. Design for lnk stand.

Mrers, Misn Flora B., 2350 Eutaw Place, Baltinore, Md. Panels.

Nea1, Mrs. Mary A., 1425 Brondway, New York City. Coffee set.

Nedwill, Miss Elizabeth A., New York City.

Nott, Eunice Erelyn, so Whilonghby St., Brookiyn, N. Y. Casket leather and copper.

0'Brien, Madeline, 184 Clinton St., Brooklyn, N. Y. Moresque window, window study.

Orr, Katharine O., Montelair, N. J. Potters.

Parix, W. F., 316 Fifth Ave., Nevr York City. Designs, black and white and water color.

Pltkin, E. Josenhine, 472 West End Ave., New York City. Pastel.

Pollion, Mrs., $12 \pi$ E. 7th St., Nerv York City. Chinaware, pottery.
Fond, Theodore IInnford, $11 \mathrm{Ham}$ liton Place, Boston, Mass. Design for dining room wall decoration, design for magazine cover, cartoon for stalned glass.

Pratt, Rosina, 3t W. 22d St., New York Cits. Leather three told screen, material oak frame.

Richarison, K., 349 Fifth Are., New York City. Book covers.

Ripley, The Misses, 434 Firth Ave., New York City. Leather screen.

Robertmon, Emma, 638 w. 169th St., New York City. Victoria hand. made lace drapery.

Robinena, Mrs. Adelnide Alsop. 114 E. 23d St., New York City. Vases.

Rogers, Mins Mnry, Tenchers' Col lege, New York City. Design for mosaic, burnt wood panel.

Rowell, Miss Fanny, Gilded plate.

Ryerson, Miss May M. L., 34 Franklin St., Morristown, N. J. Photograph of plaster rellef.

Sacker, Miss Annie M., 1478 Bencon Bt., Brookilne, Mass. Books.

simms, Florence I., 431 E. 87 th St., New York City. Deslgns for stained glass window.

sperry, Edwara s., a W. 20th st.. New York City. Cartoon for colored glass window.

Power, A. C. H. Bronzes.

Uh1, Margaret C.. 256 4th Are., New York City. Embroldered centreplece, material, linen, silk, iace.

Volkmar, Chas., Corona, $L$. I. Decoratire panels.

Walker, Miss Florence, 275 CInremont Áre., Brooklyn, N. Y. Dyed and burned decorations on heavy velvet.

Wedrill, Elizabeth A., 322 Went End Ave. New York Cíty. Mosalc designs for vestibule.

Weinert, Albert, sculntor, 218 E. 25 th St. New York City. Small portralt medallion.

Whiting, Panline, 50 w. 65th st. New York City. Burned and atalned leather.

Whitridge, Miss olive, 110 W. $82 d$ St., New York Clty.

Whilams, John, 556 W. 27th St., New York City. Bronze foundry, bronze group.

Ynndell, Miss Enid. Bronse tankard. 
The Pan-American Oncial Catalogue and Guide.

\section{Division of Liberal Arts.}

Dx. Selim H. Peabody, saperintendent,

Bogri

\2a:

Jasob 8. Otto, M. D., Asst. Supt. of sanitatlon, Ets.

Fise Minnle Broneon, Asst, Supt, of Gdroation.

\section{NATURE OF EXHIBITS.}

Educational Exhibits, Schools, Colleges, Photograpns, Pianos, Organs, Musical Instruments, Books, Scientific Apparatus, Medical and Surgical Apparatus, Social Economy, Sanitary Wares, Boards of Health, Hospitals,

Crematories, Charities.

\section{EXHIBITORS.}

\section{EOUCATION.}

AEricultural and Mechanical College, Greensboro, North - Carollaa. Photographs.

Abany Business College, Albany, N. Y. Establlshed forty-four years. Recelved Gold Medal awards for superiority in Commercial Training at Parls, 1900, and Chicago, 1893. Twenty-two teachers. Send for Catalogue. $F-25$.

Art Institute, The, Chicago, III. Drawings, designs and photographs.

Art Studenta" Lengue, The, Buftalo, N. X. Drawings. F-25.

Assoclate, Colleglate Alumnae, Buffalo, N. Y. Charts, photos, etc

Atlanta Unirernits, Atlanta, Georgla. Photographs.

Baron de Hirsch Agriculturnl \& Industrial School, Woodbine. N. J. Photos, students' work. F-25.

Model institution for secondary education. Grand Prix at Paris 1ixnosltion, 1900 . Care of the chlldren. Card system. Course of study. Model les. sons In practical agriculture.

belding Bros. \& Co., New

Instructlon iu Art; pupils' New York.
Beren College, Berea, Kentuch, Photographs.

Board of Education, Mufialo, s, Y. Photos, reports, etc. $F-25$.

Bonral of Education. Cazenorla. N. Y. Reports. F-25.

Bonra of Education, Chicago, m, Reports. $F-25$.

Bonrd of Education, Fitchburg, Mass. Reports. F-25.

Bonrd of Edncation, Harrisburs Pa. Reports. F-25.

Board of Edncetion, Kansas City, Mo. Reports. F-25.

Board of Edneation, Los Angeles, Cal. Reports. F-25.

Bonrd of Education, MnIden, Mass, Reports. $\mathrm{E}-25$.

Bonxd of Education, Nashua, N. H. Reports. F-25.

Board of Gdncation, Netrark, $\boldsymbol{N}_{\text {.J. }}$ Reports. $\mathrm{F}-25$.

Board of cincation, Pasadena, Cal. Puplis' work.

Board of Educntion, Paterson, $x$. J. Reports. F-25.

Boned of Education, Pomona, Cal, Puplls' work in varlous grades. 
board of Educntion, Portland, Oregon. Puplls' work.

Board of Education, l'rovidence, B. I. Puplls' work.

Bord of Fincation, springfield, 3ass. Leports. $F-25$.

Bord of Ednention, St. Louls, Mo. Reports. 1'-25.

Boari of Eduention, Utica, N. Y. Reports. F-25.

Board of Eancution, Worcester, Mass, Reports. F-25.

Brown University, Providence, Rhode Island. Photographs, charts, etc.

bryant \& Stratton Business Coljege, Buffalo, N. Y. Unrivaled advantgeges for teclunical business training in bookkeeping, attice methods, shorthand, typenriting, etc. Resident or col'respondence courses. Establlshed 47 years. New buliding, handsomely equipped. Vlsitors welcome. No. 95 West Genesee St. $\mathrm{F}-25$.

Baffalo Asmociation of Serving Schools, Buffalo, N. Y. Lixamples of work. $F-25$.

Baffalo Commercial \& wlectroJechanical Institute, The. Buffalo, N. Y. Students' work. $\mathrm{F}-25$.

Baffalo Seminary, Butualo, N. Y. Photographs, clarts, etc.

Bryn Marre College, Bryn Mawr, Pa. lieports. F-25.

Cnrenovia Acndemy, Cnzenovin, N. I. Photos, ete.

Chieago High Schools, Chicago, III. Drawings.

Clnfin University, Orangeburg, South Carolina. Photographs.

Clark Inirersity, Worcester, Mass. Photos, etc. F-25.

Colby College, Waterville, Matne. Photos.

College of the Holy Cross, The, and Preparatory School, Worcester, Mass. Drawings and students' work. Fin. 25 .

Are easily reached from New York and Pennsylvania. Exceptional advantages for physical trainlug. lour rears' classlcal high school and four yeur's' college course.

Colored Industrini Institute, Blue Bluff, Arkansas. Photographs.

Columbian Institution for the Deaf, Washington, D. C. Photographs, charts, etc.

Colnmbin Univergity, New Yoric Clty. Publications, Ilbrary, etc. F-25.

Cormell University, Ithrea, v. $r$. Publlcations, charts, photographs, ete.
Cory, Florence E., New York City. Drawings and designs. $\mathbf{F}-25$.

Denton 13ros., Wellesley, Mass. Butterfies. $\quad H-25$.

Department of I'ublic Instraction, State of New York. Hooks, photographs, charts.

Doolftle, Miss S. A., Binghamton, N. Y. Drawings, etc.

Fisk Univeraity, Nashville, Tennessee. Photographs.

Francaine, Ie Cercle, Cambridge, Mass. Transiations, etc. $F-25$.

Granger Place School for Girls, Cizuandaigua, N. Y. Photos and students' work. Samuel C. Fairley, Prin. A hlgh grade college preparatory school for girls, with strong Academic and Music courses. Open durlng the summer for inspection, and conveniently reached from Bufialo by the $N$. I. Central. F-25.

Hampton Normal Agricultural Institute, Hampton, Va. $\mathrm{F}-25$.

Hurris, W. T., U. S. Comintssioner of Education. Series of lllustrative charts.

Hurvard College observatoriex, Cambridge, Mass. Illuminated photos. F -25 .

Harrard University, Cambriage, Mass. Charts, photos, etc.

Harres Norminl and Industrial School, Augusta, Georgia. Photo. graphs.

Hemment, J. C., New Yorle Cits. $\mathrm{F}-25$.

Hoover, Jennie F⿱., Patergon, N. J. Photos; students' work. $\bar{F}-25$.

Horvard Univerafty, Wawhington, D. C. Photographs.

Iunt, Mrs. Mary M., Boston, Mass. Scientiflc Ieniperance.

International Correnpondence Scbools, Scranton. Pa. Photos, etc. F-25.

Jackson, A. C., Junean, Alanka. Alaska educatlonal exhiblts.

Johns Hoplcina Unirersity, Baltimore, Md. Photos, etc. F-25.

religh University, South Bethlehem, $\mathrm{Pa}$, Photos, ete. $\mathrm{F}-25$.

horrell Textile school, forell, Mass. Drawings, deslgns, methods of Instructlon.

Masanchnsetts Normal Art Selhool, Boston, Mass. Drawings, designs.

Marion. Prof. H., U, S. Nnvnl Aendemy, Annapolis, Md. Spanish and French text books. 


\section{The Pan-American Offcial Catalogue and Guide.}

Manmachnett: Normal Schools, Boston, Mass. P'hotos, reports.

Massachusetts Iustitate of Technology, Bostun, Mass. Photos, charts, etc. $F-25$.

Four year courses in engineerlng, archltecture, chemistry, biology, geology, physics, and general studies; 1277 students; 139 instructors.

Meharry College, Central Tenuexsee. Photographs.

Metropolitan Bnsiness College, Chlcago, III. Students' work, ctc. F -25 .

Mt. Holyolre College, S. Hadley, Mass. Photos a etc. F-25.

New Bedford Correspouilence Textile School, New Bedford, Mass. Drawlngs and designs.

New Haven Normal School of Gymnastles, The, New Haven, Conn. Photos, charts, etc. $1-25$.

Offers: (1) A two year's course preparlng teachers of gymnastlcs, sept.May. (2) a post-graduate course in massnge and medlcnl gymnastics, MayJune. (3) A summer course in German gymnastles, July-August.

New Jersey Exhihits of Public Schools. Charts, photographs; puplls' work.

New Jersey Normal Schools. Pupils' works, charts, photographs.

v. Y. University School of Pedagogy, New York City. Charts, plans, etc. $F-25$.

Norwich Art School. Norwich, Conn. Drawlings, etc. F-25.

Norwich Free Academy, Norwich, Conn. Drawlngs, ete. F-25.

Oberlin College, Oberlin, o. Charts, photos, etc. $\mathrm{F}-25$.

oregon Public School Exlubit, Portland, Ore. F-25.

Oswrego State Normal School, Oswego, N. Y. Reports, photos, etc.

Packard Commercial School, New York, N. Y. Photos, etr.. F-25.

Pennaylvania Reform School, Morganza, $\mathrm{Pa}$. Speclmens of pupils' mork.

Pennaylvania School of Design for Women, Phlladelphia, Pa. Draw. Ings, deslgns, etc.

Philadelphin School for Bnelaward Chlldren, Phliadelphia, Pa. Kindergarten work. F-25.

Philadelphia School of Industrial Arts, Phlladelphia, Pa. Illustrations.

Plerce Commerefin School, New York, N. Y. Photos, etc. F-25.

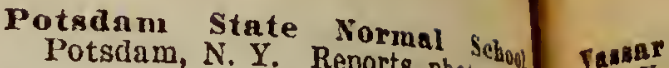
Potsdam, N. Y. Reports, photos, end rasar

Prutt Institute, Brooklyn, el
Photos, students' work, etc

Welle:

ylass.

wells

tos

Westc

West

char

Willi

Yas

Wils

phle

bist

wom

Th

F-

Wor

Coun. Physlcal a pparatus. $\mathbb{B}-23$.

Carollna. Photogr, Raleigh, Yoph

Smith, Harlan I., New York Ctt, An archaeological study of Littin

Sockamosset School, Howard, Rhode Island. Students' work.

Spencerinn Commerctal School, Cleveland, Ohio. Photos, etc. I-?

St. Lonis Mamual Training School of Washington University, St. Loull F-25.

Syracnse Classical School, \$rm. cuse, N. Y. Photos, etc.

syracuse University, Syracuse, Y. Photos, reports, etc. F-25.

Technical School for Carriagt Draughtsmen and Miechanles, Kit? York Clty. Carriage design. 1-2w,

Tifany, A. J., Chiengo, I11. nlav. tratlons of natural science. $F-25$.

Toogaloo University, Missisalpph, Photographs.

Union University, Richmond, Vit. ginla. Photographs.

University of Californin, Lick $0 b$. servatory, Mit. Hamllton, Cal. Photo. graphs, etc.

University of Chicago, Chicago, III. Reports, photos, etc.

University of Coloraro. Bonlder, Colorado. Reports, photographs, ete.

University of Illinois, Urbana, nh. Charts, photographs, students' work, etc.

University of the State of Nen York, Albany, N, Y. Department llas trations.

University of Missonri, Columbla, Mo. Photographs. charts, statistica 
Tanar College, Poughlieepale, N.Y. Photos, model of campus, etc. E -25 .

Wellesley College, Wellesley, Mass. Photos, charts, etc. $F-25$.

Wells College, Anrora, N. Y. Photos, charts, etc. $\mathrm{F}-25$.

Westchester State Normnl School, Westchester, Pa. Books, photographs, charts, etc.

Whilams College, Willametown, Hass. Charts, photos, etc. F-25.

Wilson, Mrs. L. L. W., Philadelphla, Pa. Methods of teaching natural bistory. F-25.

Women's College of BnItimore, The, Baltlmore, Md. Photos, etc. F-25.

Women'A College of Fredexick, idd. Photographs, charts, etc.

Worcester Polytechnic Ingtitute, Worcester, Mass. Photos, charts, etc. F-25.

Courses of study in mechanical, civil and electrical englneering and chemistry; 200-page catalogue, showing appolntments secured by graduates malled tree. Expenses low; 34 th year.

Iale University, Geologienl Department, New Haven, Conn. Physlcal apparatus, charts, etc.

\section{SCIENTIFIC APPARATUS.}

American Arithmoneter Co., The St. Louls, Mo. Calculating machine. $\mathrm{B}-23$.

Chnmbers, Inskeep \& Co., Chicago, III, Opthalometer.

Cross, A. Jay, Opticul Co., New York, N. Y. Optlcal instruments.

Davik, A. H., Nev York, N. Y. Artlifial eyes.

Emerson, F. W.. Rochester. N. $Y$. Drawing instruments. $\mathrm{A}-\mathbf{3 0}$.

Fox, Geo. R., 618 Main St., Bnfinalo, N. Y. Optical goods. Manufacturer of the Fox Lassoo guard for eye glasses, the Duplex Bridge Box Temple Jolnt for spectacles. Promptness, accuracy and perfect fitting guaranteed. $\Delta-26$.

Garley, W. \& L. E.. Troy, N. Y. Engineering instruments. $A-32$.

liegi Cash Reginter Co., Bonnd Brook, N. J.; Buffalo, N.' Y. Cash reglsters. $J-47$.

International Arithmachine Co. 380-384 Canal St., New York CIty. 141-149 La Salle St., Chlcago. Manu. facturing and introducing Goldman's
Arithmachine, smailest, fastest, cheapest practical computing machine. Adds, subtracts, multiplies, divides etc. Brain resting, iabor saving. Readily understood. Easily operated. Model office exblbit. $\quad \mathrm{A}-23$.

Kérel d Emer, New Yorli, N. $Y$. A-31.

Drawing materiais, surveying instruments. Branches: Chicago, St. Louls, San Francisco. Our goods are warranted and are the standard in Pan. America. We are the largest manufacturers in this line.

Mranion, J. J., Bufralo, N. Y. Optical goods. $\mathrm{P}-44$.

Mechanical A ceountant Co., Providence, R. I. Accounting machines.

Meyrowitr, E. B., New Yorlc, N. Y. Optical instruments. A-26.

National Cawin Megister, Dayton, Ohlo. Cash registers. $\mathrm{O}-33$.

Natlonnl Cashier Co., New York, N. Y. Machine for making change. A-24.

Rand, MeNally \& Co., Chicaro, III. and New York, N. Y. Globes, map and book publishers. School maps, school text-books, railroad ticket and job printers, engravers of all kinds, three-color press, half-tone, wood engraving, etc. $1-27$.

Saegunaller, G. N., muccessor to Fauth \& Co., Washington, D. C. Engdneering instruments. A-29.

Spencer Lens Co., Bufalo, N. $\boldsymbol{Y}$. Microscopes.

Spencex Opticnl Co., New York, $F$. Y. Optical instruments.

Warner \& Swamey, Cleveland, 0 . Telencopes. A-32.

\section{MUSICAL INSTRUMENTS.}

Aeolinn Company, $18 \mathrm{~W}$. $23 a \mathrm{st}$, New York, N. Y. Planola and Aeollan exhibit. Exposition visitors will be repaid for making a special polnt of hearing these much-discursed instruments. $\mathrm{B}-25$.

Albert, E. J., Philadelphin, Pa. Violing, vloloncellos, etc.

1 uekeher Co., Erklart, Ind. C-28. Band instruments.

Carmel County Organ Co. Organw. In D., L. \& W. box car.

Clark, Melville, Plano Co., ohtcago, III. Planos. B-32. 
Claviola Co., New York, N. Y. Automatic piano players. An automatlc player standing entirely alone in method of construction: compressed air, instead of suction, being used, insuring better stroke, repetition and accentuating single notes. c-26.

Conn, C. G., Elkliart, Ind. Band Instruinents. B-24.

Comsalvi, Icilio, Boston, Mrass. Banjo. B-24.

Cuonzo, Domenico, New York. Accordeons. $13-24$.

Grilearal, G.. San Francisco, Cal. Accordeon. $\mathbf{B}-24$.

De Kleist, Engene, N. Tonntrana, N. Y. Band instruments and organs. C-24.

Fonter \& Co., Rochester, N. Y. Planos. B-27.

Hainea Piano Co., Rochenter, N. $Y$. Pianos. $\mathrm{B}-27$.

Iraynes a Co., J. C., Boston, Mama. Banjos, guitars, etc. $\mathrm{B}-24$.

rimbull Co., Chicago, III. Pinnos and organs.

Krell Pinno Co., The, Cincinnat, O. Pisnos. B-29.

Ludwig \& Co., New York. N. $Y$. Planos. These Instruments are samples of which we manufacture 3,000 annuaily. Age of business 10 gears. Flrst-class workmansbip secured by written guarantee on unllmited time varrant. B-26.

Mnnnello, Angelo, New York, N. Y. Banjos, gultars, etc.

Mruxsliall \& Wendell, Albany, $N$. Y. Pianos.

Martin \& Co., Rochester, N. $Y$. Pianos. C-27.

Motrnili, J., Cleveland, Ohio. VioIIn.

Regina Munfe Box Co., New York, N. Y. Musle boxes. C-22.

Ropes, Walter S., North Alamo, Mass. Violla. B-24.

Roth \& Englehnrat, New York, N. Y. Planos. C-32.

The lartest factory devoted excluslveiy to upright piano actlon-maklng in the world. Our motto. "The Best is None too Good."

Royal Pinno Co.. The, Cincinnat, o. Planos. C-29.

Stuib-Alendschein Co.. New York, N. Y. Piano actions. $\mathrm{B}-23$.

Wense1. Nickel and Grosa, New York Clty. Plano actions.
PHOTOGRAPHIC SUPPLIES.

Buker Art Gallery, Columba, o. Photographs.

Beck, Carl, New York, N. Y. Skif. graphs.

Columisin Photo Paper Co., The New York, N. Y. Photo supplles D-28.

Enstman Kodnk Co., The, llach. ester, N. Y. Photographlc apparatu $\mathrm{D}-33$.

Lovell Dry Plate Mfg. Co. Jell York, N. Y. Dry plates, etc. Woth at New Rochelle, N. Y. "Modern Ho. tographle Dry Plates." Write for per. ticulars.

Hewett, Arthur .T., East Orange, N. J. Photographs.

photo-Era Co., The, Boston, 光ess, 'hotographs. $\mathrm{E}-28$.

Sehrimaclier. F. G., Ios Angeleh Cal. Photographs. D-31.

Simon E Bros.. Ovear A., Bufilo, N. Y. Photographs. D-30.

Steckel, George, wos Angeles, Cah Photographs. D-31.

Tillmann, Gusture, New York Photographs.

Van Normnn, Geo. N., Springteld, Mass. Carbon prints.

\section{BOOKS AND PUBLICATIOKS.}

Americnn Bible Society, Кers York, N.Y. Bible in many languges 26- $\mathrm{F}$.

American Pook Co. Ness Jork N. Y. Educational publications. 26-8.

Appleton \& Co.. D., 72 Fifth Are, New York. Bools, 1llustratlons. if Graphic Arts Bldg.

Ballin, Hans, Little Rock. Arkat. sas. Pubication: Physical Trainlu in the School Room.

Bardeen, C. W.. Syracuse, X. Y. Educational pubilcations. 26-F.

Bell, Victor C., New York. $x_{1} Y_{1}$ Publlcation: "Popular Essays on Teeth.

BiII, Edward Lyman. New York I'ublicatlon, The Muslc Trade Rerler. $\mathrm{H}-20$.

Century Co., The, Cuion Square, New York." Publications, engravings, etc. In Graphic Arts Bldg.

CIlssola, H. C., Chicago, H1. Pub. llcatlon: The Baker's Helper. 
Columbla University, New York, N. Y. Publications. H-20.

Concordin Publishing Honse, St. Loals, Mo. M. S. Firmensteln, general agent; is owned and conducted by the Cierman Evangellcal Luthcrau syod of Missonrl, Ohlo and other states, Books and publlcations. H-20.

Donbleday, Page e Co., New York. Books, lilustrations. In Graphic Arts Bidg.

Educational Pabliking Co., New York. N. X. Educational publlcations. $26-F$.

Elson Co., A. W., Boston, Mass. Pubisishers. In Graphlc Arts Bldg.

Fassett, Charles rVood, M. D., st. Joseph, Mro. Perlodical medlcal publlcatlons. $\mathrm{H}-20$.

Ford. J. Snutelle, Chicago, III. Pubilcation: Illcture and Art Trade.

Funk fe Wryalls, New Yoxlk. Books, lllustrations. In Graphic Arts Bidg.

Gibson Co.. Jos. W., New Yoxk, N. Y. Publicatlon: The Haberdasher. 26-E.

Glun Co., Ner Yorle, N. Y. Edacationai publications.

Gulding Star Publishing House, The, Chicago, Ill. Publlcatlons. In Graphic Arts Bidz.

Heath \& Co.. D. C., New York, N. Y. Educational publications. $26-\mathrm{F}$. Howe, Sara Willard, Brookland, D. C. Publlcation: The Capltol Vista. $\mathrm{H}-20$.

International Monthly, The, Baxlington, Vt. Publication. $\mathrm{H}-20$.

Jenkins, William R., Nerv York, N. Y. Books. A very complete stock of French, German and other forelgn books. Publishers of Berey's and other serles for teaching French ; Stedman's "Complete Pocket Gulde to Europe" (best publlshed). H-20.

relly \& Co., New York, N. Y. Pablishers: Directory of the Merchants, Manufacturers and Shippers of the World. $F-36$. Knaur, Erhardt, New York, Puhlication: The Manufacturers of the Unlted States. $\mathrm{E}-36$.

Laird \& Lee, Chicngo. Pablicatlons. 、In Graphlc Arts Bidg.

Leber Code Company. New York. Lleber's Standard Telegraph Code.

Maeso, Carlos M., Montevileo, Uruguay. Publlcatlon: La Tierra de Promision.

Marine Record Pabliwhing Co., The, Cleveiand, Ohlo. 26-F.
MeGraw-Mnrden Co., New York, N. Y. 26-F.

Mcliee Publishing Co., Bafalo, $\mathbb{N}$. Y. Books and publications.

Mengellinmu, Angust, Seranton, Pa. Publication.

Merrinm Co.. G. \& C., Springfeld, Mass. Webster's Dictionaries. 26-F' The International, new edltion, with 2364 pages and 5000 lilustratlons. The Colleglate, 1100 pages and 1400 lllustrations, also varlous smalier sizes, formlng a complete series.

Meyer Brothers, Druggist, st. Louls, Mo. Publlcation.

Nelmon, Charlem Alexnniter, Ibrary of Columbia University, New York. Astor Library Catalogue.

Pernin, H. M., Detroit, Mich. Publlcations.

Perry Picture Co., The, Malden, Mass. Pictures. Reproductions of the worid's great paintings. On paper $5 \% \times 8$. One cent each for 25 or more. 120 for $\$ 1.00$. Send 2-cent stamp for catalogue and sample picture.

Phonogrnulic Institnte Co., Cincinnati, O. Publicatlons.

Photo-Ern Publishing Co., The, Boston, Mass. Publication: The Photo-Era.

Raflroal Garette, The, New Tork. Publlcation: The Railroad Gazette.

silver, Burdett \& Company, New York, Boston and Chlcago. Educatlonal publicatlons. $F-25$.

Publishers of school and college textbooks and standard literature for Engllsh and Spanlsh speaklng countries. Awarded Grand Prix, Yaris, 1900.

Stern, Menco, Broolelyn, N. Y. Publlcation: Geschicten rom Rhein.

St. Lonis \& Canallan Photosrapher, The, St. Louls, Mo. 26-F. Mrs. Fltzgibbon Ciark, publisber. As an advertising medlum thls paper presents many advantages that should not be overlooked by progresslve business men. Subscription $\$ 3.00$ per year; in advance, $\$ 2.50$.

snccens Pnblimhins Co.. Ner York. Publications. In Graphle Arts Bidg.

Tugman \& Co.. Philaielphia, Pa. Books, lliustrations. In Graphic Arts Bldg.

Ware Brothers, Philndelphin, Pa. Pubilcation: The Carrlage Monthly. $26-\mathrm{F}$.

Western Union Telegraph Company. Cabie Code.

Winer, John P., Fort Monroe, Va. Pubilcation: Journal of the 0 . $\mathbf{8}$. Artiliery. $26-\mathrm{F}$. 


\section{SAIITARY WARES.}

Mott Iron Works, The J. L., New York, N. Y. Model bath room and fxtures. $F-28$.

Standara Samitary Company, Pittsburg, $\mathbf{P a}$, Bath raom and fxtures. G-28.

Trenton Potteries Co., The, Trenton, N. J. Sanltary earthenware, bath tubs, etc. The largest manufacturers of sanltary earthenware ln the world, bath tubs, lavatorles, sinks, water closets, urinals, etc., in plain white or decorated. Illustrated catalogues and prlce llst on appllcation to the trade only. $\mathrm{E}-28$.

\section{PUBLIC WORKS.}

Chicago Drainage Commission, The, Chlcago, Ill. Models of Chlcago Dralnage Canal. A-25.

Maritime Canal Co., The, Nev York, N. Y. Model of proposed Nicaragua Canal. A-25.

Masuachusetts Pan-American Commlsslon, Boston, Mass. Drawings of Publle Works in vicinity of Boston.

New Pannma Canal Co." The, New York, N. $Y$. Model of the Panama Canal. A-25.

\section{MEDICAL, SURGICAL and DENTAL APPARATUS.}

Andrewø, A. I., Chtengo, I11. Berl for surgical cases. D-29.

Rell, Vietor C., New York. Specimens of dental surgery.

Belding Bros. \& Co., Now York. Surgical and dental specialties.

Clark, A. C. et Co., Culcago, III. Uental splttoons.

Deane, Henry F., Nerv York, $N$. $Y$. Specimens of dental surgery.

Griclison Artificini Limb Co., Minneapolls, Minn. Artiflcial $11 \mathrm{mbs}$. M28.

Frees, C. A., New York. Arthelal limbs. Pergola.

Tuller, George R., Rochester, $N$. Y. Artificlal limbs. D-28.

Kny-Scheerex Co., New York, $N$. Y. Surglcal Instruments. $J-26$.

Marks \& Co., A. A., New York, N. Y. Artificlai limbs. $\mathrm{D}-26$.

Seabnry \& Johnson, Maiden Inne, New York. Surglcal instruments.

Wultatueck, C., New Tork, N. $X$. Speclmens of dental surgerJ.
CONSTRUCTIVE ARCHITECTUR:

Belding Brothers \& Co., Ner I Plans, photographs and descriptoon mills and factories.

Department of Euncatlon, schos Bureau, New York, N. Y. Model
plans of school buildings.

Howp

port

Hosp

Nep

Hos?

neQ

Hosi

No

Kleeman Co., Whlliam, New Tor N. Y. Exposition booth of Holophe Glass Co. In Eiectrlcity Bldg.

Hos!

Re

Hos

Peabody \& Beauley, Chlcago, III, It

I.

Ho:

WORKMEN'S DWELLINGS.

Tarde \& Short, New York, $x_{1}$, Model, plans, photographs, showic evolution of New York City tereme: houses.

Tenement Honse Commith Charity Organlzatlon Society of 0 of New York, N. Y. Models and phis tographs of tenement houses of th United States.

\section{INSURANCE.}

The Prudential Insurnace Cos pany of Amerlca, Newark, $\mathbb{N}$, Charts and statlstles.

HOUSES, HOMES AND SANITAMII FOR CONSUMPTIVES.

Consumptives, Free Home $100_{1}$ Qulncy St., Dorchester, Mass. Photh graphs.

Consumptives, Grove Hall Hom for, Bostou, Mass. Photographs.

Consumptires, St. Joseph's Hos pltal for, New York, N. Y. Lith graphs.

Consumatives, The Seton Hospiti for, Spuyten Duyvil, New York. Par tographs.

Sanitarium, Colorndo, Boulder, Colo. Photographs.

Sanitariam, Gabriels, Grbrlels (Adirondacks), N. Y. Photographs

Sanitarium, Loomis, Liberty, Y. Photographs.

Sanitarlum, Mnssachnsetts State Rutland, Mass. Photographs.

Sanltarinm, Sharon, Sharon, Mas, Photographs.

\section{HOSPITALS.}

Hospital, Alexinn Brother, Ohl cago, III. Reports. 
Hoopltal, Anna Jnques, Newbaryport, Mass. Reports.

Hospital, Arnot-Oxden Memorial, Newport, R. 1. Reports.

Hospital, Anbnry Methodint, Minneapolis, Mlinn. Reports.

Hospital Assnciation, Iowell, Jass. Reports.

Hospitnl, Anguatinn, Chicago, III. Reports.

Hospital, Bellevne, New York, N. Y. Reports.

Hospital. Boston City, Boston, Nass. Photographs of Isolation Hospltal. Reports.

Hospital, Bufralo General, Buffalo, N. Y. Photographs and reports.

Hospital, Cambridge, Cambridge, Iass. Photographs.

Hospital, Caruer, Boston, Mass. Reports.

Hospital, Central Maine General, Lewiston, Me. Meports.

Hospital, Charity, New Orleans, La. Photographs.

Hospital, Chester County, West Chester, Pa. Reports.

Hospital, Clildren's, Boston, - Mass. Reports.

Honpital, Children'n, Buffalo, N. Y. Reports.

Hospitrl, Cliarch Home, and Infirmary, Baitimore, Md. Reports.

Hospital, Cincinnati, Cineinunt, Oblo. Reports.

Hospital, Clinton Associntion, Clinton, Mass. Reports.

Hospital, Concord Association, Concord, N. H. Reports.

Hospital, Cooper, Cnmden, N. J. Reports.

Hospital, Davis, for Contaglous and Infectious Diseases, Lancaster, Pq. Plans.

Hospital, Fablola, Onkland, Cal. Photographs.

Hoxpital, Faxton, Utica, N. Y. Reports.

Hosplinl, Freedinen's, Wrahington, D. C. Reports.

Hospital, French, San Frnncisco, Cal. Photographs.

Hompitnl, Garfeld Memorial, Washington, D. C. Reports.

Hospitnl, General Protestant, ottawa, Canada. Reports.

Hospital, Good Snmaritan, Fortind, Ore. Reports.
Hospital, Good Shepherd, Syracuse, N. Y. Reports.

Hospital. Germnn, San Franctaco, Cal. Photographs.

Hospital. Hartford, Hartord, Conn. Reports.

Hospital, Honse of Merey, Pittsfield, Mass. Reports.

Honpital, Hownrd, Philadelphia, Pa. (Broad and Catherlne Sts.) Re. ports.

Hoxpital, Jeferson Medienl College, Phlladelphla, Pa. Charts.

Hospital, Johns Hopkins, Haitimore, Md. Plans, reports, pubilcations, photographs.

Hospital, Lakesile, Clevelnnd, 0 . Reports.

Hompitnl. Lavrence Genernl, Lawrence, Mass. Charts.

Hompital, Maine General, Portland, Me. Reports.

Hospital. Mriflen, Malden, Mans. Reports.

Honpital, Margaret Plllmbury, Concord, N. H. Reports.

Hospital, Massnchusetts General, Boston, Mass. Reports.

Hospital, Massnclinsetts Homeopathic, Boston, Mass. Reports.

Hospital, Medico-Chirurgteal, Philadelphia, Pa. Reports.

Hospital, Hemorinl Assoclation, New London, Conn. Reports.

Hospital, Mercy, Chicago, Ill. Reports.

Hompital, Methodist Eplscopal, Brooklyn, N. Y. Reports.

Honpital, Methodist Euscopal, Philadelpbia, Pa. Charts.

Hospital, Middletoryn Armociation, Middletown, N. Y. Reports.

Hospital, Morton, Taunton, Mass. Reports.

Hospital, Monnt Sinai, Nerr York, N. Y. Reports.

Hompital, Mrountain Side Asmocintion, of Essex County, Montclair, N. J. Reports.

Hospital, Muluenlurg, Plainfleld, N. J. Reports.

Hospltal. New Eugland, for Women and Children, Boston, Mass. Reports.

Hospital, New orlenns Bonrd of Health, New Orleans, La. Plans of Isolation Hospital.

Hospital, Newport, Newport, R. I. Reports. 
Hospital, New Tork Cancer, New York, N. Y. Reports.

Hospital, Ner Yorle Founding, New York, N. Y. Photographs.

Hospital, Northwestern, Minnenpolis, Minn. Reports.

Honpital, oll City, oll City, Pa. Reports.

Hospital, Orange Memorial, Orange, N. J. Reports.

Hospital, Paterson Isolation, Paterson, N. J. Photographs.

Hospital, Penusylunin, Philndelplia. Pa. History of Hospital; photographs.

Hospital, Philadelphia Lying-In, Charity, Philadelphia, Pa. Reports.

Hospital, Polselinic, Philndelphir, l'a. Reports.

Honptal, Preshyterian, New York. N. Y. Model of ward ; photographs; blanks; charts ; reports.

Hosnital, Presbyterian, Philadelphia, Pa. Reports.

Hospital. Protestant Cpiscoprl, Philadelphía, Pa. Reports.

Fospital, Quincy City, Quiney, Mass. Reports.

Hompital, Rhode Island, Providence, R. I. Reports.

Hospital, Rochester City, Rochester, N. Y. Publications.

Hospital, Rochester Homeopathic, Rochester, N. Y. Reports.

Hospital, Rockfora Assaciation, Rockford, III. Reports.

Hospital, Roosevelt, New York, N. Y. Photographs.

Honpital. Saginnw Generny, Saginaw, W. S. Michlgan. Reports.

Honpital, Snlem, Salem, Muss. Reports.

Hospital, Sherman, Elgin, n1. Reports.

Howpital, Sloan Maternity, New York, N. Y. Photographs.

Hospital, st. Agnes, Philndelphin, Pa. Reports.

Honpital of St. Brrnahas, Morristown, N. J. Publications.

Hospital, St. John'w Grild, Flonting, New York, N. Y. Photographs.

Hospita1, St. Louis Mullanphy, St. Louis, Mo. Reports.

Hompital, St. Lulie's, New Bedford, Mass. Reports. Hospitni, St. Lnke's, New York, N.
Y. Photographs.
Hospita1, St. Mary's Free, to Lagne, Children, New York, N. Y. Aloded do ylass. ward.

Mospitni, The Mary Hitcheoen Hosp? Memorial, Hanover, N. 由. Reports grapb

Hospital, The Mary Thompun Insane Chicago, III. Reports.

Hospital, The Thrnll, Middletorn,
N. Y. Reports. Irosptal. The Willinm W. Backn,
Norwich, Conn. Reports.

Hospital, University, Ann Arbor, Mich. Reports.

Hospital, Vanderbilt Cunic, Ieti York, N. Y. Photographs, reports.

cospital, Waltham, Walthan Mass. Reports.

Hospital, West End Nursery, and Infants, Boston, Mass. Reports.

Iospitnl, Winnipeg Genernl, Win. nipeg, Canada. Reports.

Hospital, Worcester City, Wor. cester, Mass. Photographs, chard reports.

Hospital, Worcester Isolation, Worcester, Jlass. Plans, photographa

Influmary, New York Eye and Ear, New York, N. Y. Reports.

Infimary, New York, for Women and chlidren, New York, N. Z. B ports.

Infrmary, The $s$. R. Smith, Tew Brlghton, Staten Island, N. Y, R ports.

Infirnney, Touro, New Orlean, La. Reports.

\section{INSTITUTIONS FOR THE INSAKE.}

pitai

grap!

Insin

pital

grap

Insan

pita

gra?

[nsa]

pits

I.

Insa

for

Ins

pit

gPI

Ins?

10

Ins:

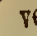

Ins

Ins

1

In

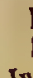

In

II

Insnne, Agnews State llaspitsl for, Okiah, California. Photographs.

Insरne, Anstin Fnrin, Manicipal Hospital for, Boston, Mlass. Phota graphs.

Insane, Dinghamion State Hos. pital for, Binghamton, N. Y. Pboto graphs.

Insane, Bloominganle. Prirate Hospital for, White Plains, N. Y. Photographs.

Inanne, Brigham Hall Prirate Hospital for, Canandaigua, N. Y. Pho tograplas.

Insane, Bnfinlo State Hospitnl lor, Buffalo, N. Y. Photographs.

Insane, Californin Stute Hospital for, Stockton, Callfornia. Photo graphs.

Insane, Connecticut State Hos. pital for, Middletown, Conn. Photo graphs. 
Insane, Danvers Ilospital for, Danvers, Mlass.

Insane, Enstern Incisuma State Hospltal for, Richmond, Ind. Whotograpbs.

Insane, IIadmou Iricer Strte Hospltal lor, I'oughicensle, N. Y. Y'hotagraphs.

Insane, Indelemicnce Strie Hospital for, Independence, Iowa. Photographs.

Insane, Little Rocls State Hospital for, Little Rock, Ark. Photographs.

Insane, Long Islami States Hospital for, King Park, Long Isiand, N. i. Photographs.

Insane, Manlinttan State IIospital for, New Iork, N. Y. Photographs.

Insane. Mrssnchusetts State Howpital for, Bridgewater, Mass. Photograplus.

Insane, Mattearran State Irospital tor, Matteawan, N. Y. Thotographs.

Insane, McLenn Irospital for, Waverley, Mass. Photographs.

Insune, Medifela State Irosptal tor, Medfeid, Mass. Photographs.

Insaue, Mendocine Strite Insuital for, Oklak, Callfornia. Photographs.

Insane, Middletown State Hogpitai for, Middletown, N. Y. Photographs.

Insane, New Jersey Stute Tompital for, Morris Plalas, N. J. Photographs; reports.

Inkane, New Jersey State llospitnl for, Trenton, N. J. Photographs; repor's.

Inkne, Northern Inilinn State llospltal for, Longcilife, Ind. Photographs.

Insane, Pennsyvanin State Fospital for, Philadelphia, Pa. Photographs.

Insane, Plexce Farme Tunfelugl Hospital for, Philadelphia, Pa. Photographs.

Inane, Rochester State Hospital for, Rochester, N. Y. Photographs.

Insane. Souther. Indiana State Hospital for, Evansville, Ind. Photograplas.

Insune. St. Iarrance Stute Hospital for, Ogdeusburg, N. Y. Photograplas.

Insune, Utica State Iospital for, Utica, N. Y. Photographs.

Insine, Wilnral State Inspital lor, Wlliard, N. Y. Photographs.
Inxane, Worcester Lospitnl for, Worcester, Mass. Photographs.

\section{PUBLIC HEALTH.}

Abbott, Dr. Sammel vV., Instom, Mass, plotographs, charts, dirgrams on Pubilc Hygiene in the United States.

Alexamier, Dr. H. M., Marietta, Pa. Vaccine.

American Climatological A.ssociation, Philadeiphla, Pa, Reports.

Auerican Public Foalth Associa-. tion, Columbus, Ohio. Publications.

liatir Depantment, Hoston. Mass. Photographs.

Drth Hewse Committee, Brookline, Mass. I'hotographs; pians.

Monver of Health, Boston, Mass.. Photograpls, circulars and clarts.

Monril of IIenti, Broolitine, Mras. Photographs.

Honxd of Heath, Bufrio, N. Y. Photographs, charts and statistics.

Hoaxd of Healti, Califorin state, Sacramento, Cal. Reports.

Ionra of Ienlth, Cansulige, Mass. Reports; photographs.

Honril of Ienlth, Charleston, S. C. Reports.

Honid of Healtl:, Chicago, MI. Photographs, reports, etc.

Bonrd of Ireaiti, Cincinnati, ohio. Reports.

Honxd of Iealth, Cleveland, Ohio. Reports.

IBonrd of Mealth, Colorndn Stnte. Denver, Colo. Blanks, charts, etc.

Eoard of Health, Connecticut stute, Hartford, Conu. Charts, naps, reports.

Bonrd of Henlth, Delnware State, Dover, Del. Reports.

Bonra of Henlth, Detroit, Mich. Reports.

Boami of Iferith, Florida Stnte, Tallahasee, Fia. Reports.

Bonra of Menlth, Indiann Siate, Indianapolis, Ind. Reports, circulars, etc.

Bonri of Kealti. Towa State, Des Molnes, Iowa. Reports.

Bonril of Ireaith, Kansas state, Topeka, Kan. Reports.

Bond of Henlti, Kentucky State, Franbiort, KJ. Reports.

Hoard of Henth, Mnine State, Augusta, Me. Reports, charts, circuiars, etc. 
Board of Henlth, Maryland State, Baltimore, Md. Reports, circulars, etc.

Bonrd of Menith, Massachusett. State, Boston, Mass. Maps, charts, reports, photographs.

Board of Henith, Michigau State, Lansing, Mich. Maps, charts, reports.

Board of Health, Mifiwankee, Wis. Reports.

Board of Menlth, Minnesota State, St. Paul, Minn. Reports.

Board of Health, Missonri state, Kansas City, Mo. Reports.

Board of Health, National, WashIngton, D. C. Reports.

Board of Health, Newark, N. J. Reports.

Board of Health, New Hampshire State, Concord, N. H. Reports, clrculars.

Board of Henith, New Jersey State, Trenton, N.J. Maps, charts, reports, photographs.

Board of Health, New Orleans, La. Maps, charts.

Hoard of Health, New York, N. Y. Reports.

Board of Health, New York State, Albany, N. Y. Publicationg, statistics, methods.

Bonrd of Health, Ohio State, CoJumbus, Ohlo. Reports, charts.

Board of Health, Oklahoma Territory, Oklahoma. Reports.

Boaral of Menith, Patermon, N. J. Photographs, reports.

Board of Herlth, Pennmylvania State, Harilsburg, Pa. Photogiaphs, charts, reports.

Board of Health, Philadelphia, Pa. Maps, charts, photographs, reports, apparatus.

Board of Health, Pittsburgh, Pa. Maps, charts, photographs, reports and blological products.

Hoard of Health, Providence, R. I. Maps, charts, reports.

Board of Health, Reading, Pa. Reports.

Foard of Health, Rhode Imland State, Providence, \&. I. Charts, maps, reports.

Bonrd of Health, San Francimeo, Cal. Reports.

Board of Health, South Carolina State, Charlestown, S. C. Reports.

Board of Fealth, st. Lonin, Mo. Maps, charts, reports.
Board of Health, St. Paul, Mlia,
Maps, charts, reports.

Honad of Henlth, Vermont state Montpeller, Vt. Charts, maps, phota graphs, reports.

Board of Henlth, Washington, $D$,
C. Reports.

Bonrd of llealth, Wauhingion State, Seattle, Wasb. Reports.

Hoard of Health, Wisconsin statt, Madison, Wls. Reports.

Bonrd of Health, Worcenter, Yau. Photographs, reports.

Buffalo Society for the Prevention of Tuberculosis. Charts, statistics.

Connecticut Agrienitural Expers. ment station, New Haven, Conn. Re ports.

Dairy Commission, Trenton, $\mathrm{X} . J$, Reports.

Dairy \& Food Division, Michigan State Department of, Lansing, Wich. Reports.

Department of Agriculture, Ba. reau of Animal Industry. Washing. ton, D. C. Reports.

Department of Agrieniture, Dirl. slon of Chemistry, Washington, D. C. Reports.

Department of the Interlor, Cen. sus Bureau, Washington, D. C. Re ports, charts.

Department of State, Mausachn. setts, Boston, Mass. Reports of regls tration.

Department of the Treamry, v.s. Marine Hospital Servlce. Report, pamphlets.

Pocono Laboratoriem, The $D_{r}$. RIchard Slee, Swlftwater, Pa. Vac clne.

Quarantine Station, Port of Nerw York, Staten Island, N. Y. Model, photographs, charts.

Street Cleaning Department, Boston, Mass. Photographs.

street Cleaning Department, Nerr York, N. Y. Photographs.

Vital Statistics, Division of, Michigan State Dept., Lansing, Mich.

\section{CREMATORIES.}

Cemetery Association, The $\mathrm{Cr}$. press Lawn, San Francisco, Cal. Photographs of crematory.

Cemetery Associntion, The odd Fellows, San Franclsco, Cal. Photo. graphs of crematory. 
Cemetery, The Forest Iome, Company, Mlilwaukee, Wis. Photographs of crematory.

Cremation Company, The Cincinoatl, Cinclanati, Ohio. Photographs.

cremation Company, The United States, New York, N. Y. Photograpils.

Cremation, The Dnvenport Soclety for, Boston, Mass. Photographs. Cremation, The Philndejp.in Soclety for, Phlladeipbla, Pa. Photograplis.

Crematory, The Gardner Enrl Cliapel and Oakwood Cemetery, Troy, N Y. Photographs.

Crematory, The Le Moyne, WanhIngton, Pa. Photographs.

\section{AIO AND CHARITABLE INSTI- TUTIONS.}

Aid Associntion, Organixed, Jersey Clty, New Jersey. Reports.

Aimshouse, Massuchusetts State Terksbury, Mass. Photographs and statistles.

Asnociation for Improving the Condition of the Poor, Brooklyn, N.Y. Photographs, reports.

Associntion for Improving the Condition of the Poor, New York City. Reports, photographs, charts.

Blind, Industrinl Home for, Knoxvilie, Iowa. Photographs.

Charitable Society, Lndies Union, Lawrence, Massachusetts. Reports.

Cinritles Ald Asmociation. New York State, New York, N. Y. Publications.

Chnrities and Corrections, Bonrd of, Coiorado State, Denver, Colorado. Publications, statIstics, photographs.

Charities and Correetions, Bonrd of, Minnesota State, St. Paui, Minn. Reports, statistics.

Charities nnd Correctious, Board of, Rhode Island State, Providence, Rhode Island. Reports.

Charities and Corrections, Department of, Philadeiphia, Pa. Re. ports, pubilcations.

Chnritien nnd Correctionx, Nntional Conference. Proceedlazs.

Charities nnd Lunacy, Hoard of, Massachusetts State, Boston, Mass. Reports, statistics.

Charities, Associnted, Boston, Massachusetts. Photographs, statistics, reports.
Charlties, Associnted, Cambrige, Massachusetts. Statlstics, charts, blanks, reports.

Charities, Amsocinted, Cincinnnti, Obio. Bianks, reports, statistics.

Chnrities, Amsoelated, District of Coiumbia, Washington, D. C. Reports, blanks, statistics.

Clinrities, Aswocinted, Ft. Wayne, Indiana. Reports.

Clinrities, Asmointed, Fewbnrgh, New York. Reports.

Chnritiew, Associnted, Snn Francisco, Cal liegorts.

Chroritew, Associated, Wlimington, Neiaware. Reports.

Charities, Associntion, United, Akron, Ohlo. Reports.

Charities, Bonrd of, Connecticut State, Hartford, Connecticut. Reports.

Charities Bonril of, District of Coiumbia, Wasuington. Photographs, reports.

Clinrltes, Bonrd of. Indiana State, Jadianapolis, Iud. Reports.

Clinrities, Bonril of. New York State, Albany, N. Y. Publications, statistics, plotographs.

Charities, Noari of, Ohio state, Columbus, Ohio. Photographs, reDorts.

Cinrities, Bonril of, Pennsyivanio State, Harrisburg, Pa. Reports.

Chnrities, Burenu of, Monnt Vernon, N. Y. Reports.

Charity, Bonra of, Mansnchusetts State, Boston, Mass. Publications, statistics, photograpbs.

Charity, Board of, Michigan State, Lansing, Mich. Reports.

Charity Organization soclety, Baitimore, Maryland. Pbotographs, charts, statistics.

Charity Organization Soeiety, Buffaio, N. Y. Photograpbs, reports, blanks.

Cinrity Organization Society. Denver, Coiorado. Reports, charts, photograpbs, circuiars.

Charity Organization soelety, New York, N. Y. Photographs, reports, charts, publications.

Children's Aid Soelets, Boston, Mass. Statistics, photographs.

Chlluren's Ald Soclety, New York, New York. Reports, publications.

Children's Ald Society of Pennsyivania, Pbiladelphia, Pa. Reports.

Children's Gandinn, Board of Marion County, Ind. Reports. 
Children's Guardian, Bonrd of Vigo County, Ind. Ieports.

Chidren's Institutions Demartment, Boston, Mass. Photographs, statistics.

Control, Bonril of. Iorra stnte Institutions, Des Moines, Ia. Reports.

Denf and Domb, Institution for the Instructlon of the New York. N. Y. Photographs, pupils work.

Denf aud Dnmb, New York Institution for the Instruction of the, New York City. Photographs and work of pupils.

Denf and Dnmh, School for, Nebraska State, Omaha, Neb. Reports.

Denr, School for, Maine State, Portland, Me. Reports.

Feeble Minded, Indiana state School for, Fort Wayne, Ind, Reports, photographs.

Feeble Minded, Iown State Institution for, Glenwood. Ia. Photographs, reports.

Feeble Minder, Massachnsetts State School for, Waverly, Mass. Photographs of grounds and bulldings.

Feeble Minded, Mrichignn State Home for, Michigan. Reports.

Fecble Minded, Minnesotr State School for, Taribault, Minnesota. Photographs, reports.

Feeble Minded, Ner York State Institutlon for, Syracuse, N. Y. Photographs.

Feeble Minded, Wisconsin stnte School for, Chippewa Falls, Wis. Photographs of instltutions.

Home for Agen Conples. Trustees of Massachusetts, Boston, Mass. Yhotographs, reports.

Home for Afed Men, Trustees of Massachusetts, Boston, Mass. Photographs, reports.

Home for Aged Women, Trustees of Massachusetts, Boston, Mass. Photographs, reports.

Home, Children's, Franklin County, Columbus, Ohio. Reports.

Home, Illinois Soldiers', Qniney, III. Photographs of buildings.

Home, Iova Solliers', Marshalltou, Ia. Photographs.

Home, Isnbelln, Heimath, New Iork, N. Y. Photographs, reports.

Home, Masinchusetts Suldiers', Chelsea, Mrass. Photographs.

Home, Minnesota Soldiers' Minnesota. Photographs.
Home, National, for Disabiel $\mathrm{r}_{01 .}$ Poos, unteer Soldiers. Washington, D. C
Reports.

NeW

Home, Ohio Soldiers' and salloor, Sandusky, Ohio. Photographs Sallow'.

Home, Preshyterian, Women, New York, for Anel Hor

Home, Reports. ford, N. X. Photographs Corps, Or.

poor

Ma:

tics

Home, Working Women's Tempo. rary, Boston, Mass. Photographs

House of Reformation, Eosto City, Boston, Mass, Statistics,
ports.

House or Tiefnge, Boys' Depart. ment, Glen Mllis, Pa. Photographs publlcations.

Indnstrinl Sehool for Boys, El. dora, Ia. Plootographs.

Industrinl School for Crippled and Deformed Chlldren, Boston, Mass Reports.

Industrigl School for Girls, Maine State, Haloweel, Me. Reports.

Industrial School, New York State, Rochester, N. Y. Photographs charts, publications, specimens of work.

Insanity, Board of, Massachusett State, Boston, Mass. Photographs, statistics.

Lyman and Industrial Schook, Trustees of, Westborough, Mass. ho ports, charts, photographs.

tumnes, Commission in New York State, Albany, N. Y. Reports.

MeGarr, Thomas G., Albany, X. Y. Photographs and reports showing the development of the asylum system and care of the Insane in the United States.

New York Jyvenlle Asyinm, Iew York, N. Y. Photograplus, reports.

Orphnu Asylum, Jewish, frew 0rleans, La. Photographs.

Orpluan Asylnm, New York, Nem York. Photographs, reports.

Orphan Asylam, Rose, Terre Haute, Ind. Statistles, photographs.

Orphan Asylnm, Society of , City of New York, N. Y. Reports.

Orphan Asylum, Washburn Memorial, Minneapolis, Mlan. Reports.

Orphan Home. Charleston, Charleston, South Carolina. Reports.

orphan Home, Iown Soldlers', Davenport, Ia. Photographs.

ornhans, Mimesota Home for, Minnesota. Photographs.

Poor Moys, McDonongh School for, McDonough, Md. Reports, photo graphs. poor

vel

grs

Poo

II

gt

Poc

te

g

$\mathrm{Pr}$

$\mathrm{Pr}$

P

P 

Dol. Poor, Connty superintendents of
New York State. Proceedings.

poor, Overseers of the. Foston, Nass. Photographs and statistics of Wayfarers' Lodge and T'emporary Home.

Poor, 0rerseers of the, Brockton, Mass. Reports, photographs, statistles.

Poor, overseers of the, Fairharen, Mass. Reports, statistics, photographs.

Poor, Overseers of the, Natick, Mass. Reports, statistics, photographs.

Poor, Overseers of the, Worcester, Mass. Regorts, statistics, photographs.

prevention of cruelty to Children, llinols Society for the, Chicago, iil. Reports.

Prevention of Crnelty to Children, Massachusetts Society for, Boston, Mass. Reports.

Prerention of Crnelty to Children, Soclety for, Brookiyn, N. Y, Reports.

Prevention of Cruelty to Cluidren, Society for, New York State. Reports, photographs, statistics.

Prevention of Crnelty to Children, Society for, Pennsylvania State. Reports, photographs, statistles.

Prison Associntion, Mrssacliusetts, Boston, Mass. Keports.

Prison, Mnine State, Commission, Augusta, Me. Reports.

Prison, Massachusetts State, Commissioners of, Boston, Mass. Reports.

Prison, National, Asscocintion. Publicatlons.

Protectory, New York Cuthollc, New York, N. Y. Photograpbs, reports, publications.

Provident Association, Boston, Mass. Reports.

Provident Association, St. Louis, Mo. Reports.

Public Landis nud Bulldings, Board of, Nebraska State, Lincoln, Neb. Publications, statistics.

neformatory, Nerw York State, E1mira, N. Y. Reports, photographs.

Rellef and Ald Associntion, Chicago, III. Reports.

Rellef and Employment of Poor of City of Phlladelphla, Guardian for, I'hliadelphia, Pa. Reports.

Retreat, Hartford, Hartford, Conn. Photographs.
Whittier Reform School, Whittler, Cal. Photographs.

[Tine Charities Exhibit is the property of the Charity Review, New York City, and was collected by Mr. Idward T. Jevine and Mr. Homer Folks.]

\section{INDUSTRIAL PROGRESS: STATISTICS.}

Alabama Land and Development Company, Moblle, Alabama. Photographs.

Atchison, Topeka \& Santa-Fe Raiiroad, Chicago. Publications.

Hauk Commissioners, New Hampshire Boards of, Concord, New Hampshire. lieports.

Rauling, Commisstoner of, of Pennsylvania, Philadelphia, Pennsylvania. Reports.

Bonrd of Arbitration, Massnchnsetts State, Boston, Mass. Reports and statistics.

Bonid of Arbitration, Ohio State, Columbus, $O$. Reports and statistics.

Bonrd of Trade, Chicago. Reports.

bonrd of Trade, Tampa, Flortia. Photographs.

Brotherhool of Locomotive Engineers, Cieveland, Ohlo. Publicatlons.

Building and Lonn Associntion, California, Sacramento, Cal. Reports of proceedings.

Building and Lonn Associations, Illinois State League, Springfield, IIlinols. Documents.

Hullding nnd Lonn Associntions, Indiana State League, Indianapoils, Indiana. Documents, etc.

Bullding nud Lonn Associntion, Louisiana State League, Baton Rouge, Loulsiana. Documents, etc.

Bullding and lonn Associntions, Massachusetts State Licague, Boston, Mass. Documents, etc.

Bnilding nnd Lonn Associntion, Metropolitan League of New York, N. Y. Documents, etc.

Bulding and Lonn Associations, Milchignn State Leagne, Lansing. Mich. Documents, etc.

Building and boan Association, Missourl State I.eague, Jefferson City, Mo. Documents etc.

Bullding and Lonn Associations, National League of, Washlngton, D. C. Documents, etc. 


\section{The Pan-American Official Catalogue and Guide.}

Bullaing and Loan Associntion, Wisconsin State League, Madison, Wisconsin. Documents, etc.

Building and Loan Commission of New York, New York. Reports.

Bureau of Labor Statintice of Massachusetts, Boston, Mass. Charts showing concentration of industries into iarge estabilishments.

Carriage Monthy, Phlladelphin, Penna. Publication, map of carriage manufacturers.

Chamber of Commerce, Los Angeles, Cailfornia. Photographs.

Chamber of Commerce. Santa Ana, Californla. Photographs.

Chicago Northwestern Rallway. Chicago. Photographs.

Columbus Face Brick Company, Columbus, Ohio. Photographs.

De La Mnr'n Merenr Minen Company, Mercur, Utah. Photographs.

Dangan, Hood \& Company, Philadeiphia, Penna. Photographs.

Engineering Magazine, 120 Lberty Street, New York. Pubilications.

Engineering News Pablishing Company, 220 Broadway, New York. Pubilcations.

Glas: Pottery Worla Company, 21 Quincy Street, Chicago. Pubilcations.

Hammonisport Wine Company, Hammondsport, N. Y. Photographs.

Harvard Co-operative Sochety, Cambridge, Mass. Publications.

Helnz \& Company, Pittsburg, Pa. Photographs of buildings and grounds.

Herald Publishing Company, Steubenville, Ohlo. Photographs.

Hires Turner Glass Company, 626 Arch Street, Philadelphla, Penn. Pho. tographs.

Hocking Valley Rallroad, Columbus, Oĥlo. Photographs.

Hotel Monthly, 325 Dearlorn St., Chicago. Publications.

Independent Order of Revanbiten, New York. Reports.

Infermoll-Sergeant Drill Company, 26 Cortlandt Street, New York.
Photographs.

Innpection of Fractories. Conn. State Bureau of, Hartfordes, Conn. Reports : inspectlon bianks, statistics.

Inmpection of Factories, Ininois State Bureau of, Springfeld, III. Reports, Inspection blanks, statistics.
Inspection of Factories, Indes calgh State Bureau of, Indianapolla, In Reports, inspection blanks, statistlo
photographs.

Inspection of Factorian reau State Bureau of, Boston, Man, tistl ports.

Inspection of Factorien, Mich gan State Bureau of, Lansing, Hio Reports.

Inspection of Factories, Sew Jer sey State Bureau of, Trenton, $X, j$. Reports.

Inspection of Factories, $x_{t h}$ York State Bureau of, Albanj, X. I. Reports, inspection bianks, statlistion photographs.

Inupection of Factories, $0 \mathrm{bl}$ State Bureau of, Columbus, Oblo. ph ports, inspection bianks, statistion photographs.

Inspection of Fretories, Pennsy. vania State Bureau of, Harrsbona, Penna. Keports.

Inspection of Factories, Rhodel. iand State Bureau of, Provldence Rbode Isiand. Reports.

Inspection of Mines, Callfornls State Bureau ot, Sacramento, Cal, Bt ports, photographs, statistles.

Inspection of Mines, Illinoli State Bureau of, Springtield, III. Rt ports, photographs, statistics.

Inmpection of Mines, lown State Bureau of, Des Molnes, Iowa, Be ports, photographs, statistics.

Inspection of Mines, Kansas State Bureau of. Topeka, Kansas. Repots photographs, statistics.

Inspection of Mines, Kentuchy State Bureau of,' Frankfort, Kentucky. Reports, photographs, statistics.

Inmpection of Mines, Maryland State Bureau of, Baltimore, Mda. he ports, photographs, statistles.

Inspection of Mines, Montana State Bureau of, Helena, Montan. Ieports, photographs, statistics.

rnspection of Mines, Ohiu Stato Bureau of, Columbus, Oblo. Report, photographs, statisties.

Inmpection of Mines, Pennaylvania State Bureau of, Harrisbur, Penna. Reports, photographs, statls. tics.

Invpection of Minex, West Vir. glnia State Bureau of, Wbeeilng, W. Va. Reports, photographs, statistice.

Jomes, Eaw., D., Madison, Wla. Charts and maps illustrating resources and industrles of the country. 
Kanghts of Mncenuees, Port Buron, Michlgan. Reports.

Labor, Massachusetts State Bareau of, Boston, Mass. Reports, statistles.

Lellgh Valley Rallroad, 26: Cortlandt Street, New York. Reports, photos.

Locomotive Englueers, Brothertood of, Cleveland, Oblo. Publicatlons.

Manlattan Storage and Warehouse Company, Lexington Ave. and 420d Street, New York City. Photographs.

Yassachusetta Savinga Bank Commlssloners, Boston, Mass. Charts showing development of saving bank system, increased deposits, etc. Reports.

Massachusetts State Insurance Commlssloner, Boston, Mass. Charts showing extent of life Insurance buslness In Mass.

Ircormick Harvester Co., Chicago. Photographs.

New York State Banking Department, Albany, N. Y. Reports, statlsIles.

New York state Insurance Department, Albany, N. Y. Reports.

Northwestern Miler, MinneapoIIs, Minn. Publications.

Ores and Metals, Denver, Col. Publleations.

otis Elevator Company, $108 \mathrm{Lb}$ erty Street, New York, N. Y. Photographs,
Review and Heruld Publlwhing Company, Battle Creek, Michigan. Photographs.

Royal Arcnnum, Bonton, Mawa.,
Pubilications.

Rutland Rallroad Company, Ratland, Vermont. Photographs.

Schieren, Charles A., Company, 45-50 Perry Street, New York, N. Y. Photographs.

Sheffleld Car Company. Three Rivers, Michlgan. Photographs,

Southern Paeife Rallway, Chtcago. Photographs.

Standard Varnieh Workm, 28 Broadway, New York. Photographs.

Studebaker Bros. Manufacinring Company, South Bend, Indlana. Photographs.

Tin and Terne and the Metal World, 53 Ninth Street, Pittsburg, $\mathrm{Pa}$. Publication.

Tobacco Lenf Pabliahing Company, 53 Maiden Lane, New York City. Publications.

Trigg WHilam R., \& Co., Rlchmond, Vlrginla. Photographs.

Triamph Ice Machine Co., Cinclunati, Ohlo. Photographs.

Vermont Marble Co., Proctor, Vermont. Photographs.

Weatinghouse Co., Pittubrg, Pa. Photographs.

Winslow Brom., Co., The, Carroll Ave, and Fulton Street, Chlcago, III. Photographs.

Wood, Walter A., Mowlug and Reaplng Machine Company, Hoosick Falls, New York. Plıotographs. 


\section{Division of Foods and Their Hecessories}

Frederiek W. Taylox, Superintendent.

Nohic

ark,

intlo

Trus

c. Edurand Fullex. Assistant Superintendent.

relso

Stor

Chi

Bee

refi

EXHIBITORS.

sag

pro

Nest?

Akron Cerenl Co., The, Akron, o. D. 49 .

American Cereal Co., The, $90 \mathrm{w}$. Broadway, New York. D-42.

Armaby, J. K. Co., 44 River st., Chlcago, IIl. F-49.

Arethuma Spring Water Co., Seymour, Conn. D-36.

Armour \& Co., 205 La Sallo st., Chlcago, III, D-45.

Borden' Condensed Muk Co., 71 Hudson St., New York, N. Y. A-46. Originators of Condensed Milk. Estabilshed 1857. Proprletors of the celebrated Gail Borden Eagle Brand Condensed MIlk, Peerless Brand Evaporated Cream. Condensed Coffee.

Chapman Co., John M., The, New York. Sauces.

Consumers' Company, The, 35th and Butler Sts., Chlcago, III. C-46.

Davis Milling Co, R. T., st. Joseph, Mo. C-37.

Dola Preking Co., Jacob, Duffalo, N. Y. F-51.

Egg Baking Powder Co., So West St., New York. D-48.

Exle Preserving Co., Buffalo, N. $Y$. $\mathrm{C}-44$.

Falrbank Co., N.K., The, 277 Dearborn St., Chicago, III. G-29.

Fisher \& Co., B., 397 Greenwich St., New York. care C. D. Petrie, Buffalo, N. Y. D- 40 .

Geneva Mineral Water Co., Brooklyn, N. Y. B-44.

Geneva Minerai (utbia) Water as produced in nature's laboratory. Buffalo's depot, $50 \mathrm{~W}$. Eagle St. Maln offce, 20 Court St., Brooklyn, N. Y. Perfectly pure. Pleasantly practical. Pan-American peoples know its virtues and profit by them. See our exhibit. Try a sample and get some interesting Information and a beautiful
souvenir.
German-Amerienn Provision $\mathrm{C}_{\mathrm{O}_{14}}$ The, Union Stock Yards, Chicago, ill $\mathrm{G}-46$.

Exhibit of Hlue Ribbon Brand Canat Meats, fancy sausages and crean table lard.

Helde, Henry, 84 Vandnm St., Jer $_{\text {in }}$ York, N. Y. C -49 .

Confectionery, manufacturer of tha celebrated Diamond Brand Conte tionery, Genulne Almond Paste to baking macaroons, and the renownes 5-cent specialties: Licorice Pastille Mint and Assorted Jujubes.

Ieinz Co., H. J., Pitsburg, $\mathrm{P}_{\mathrm{g}}$ C-36.

Heelcin \& Co., James, Walnut and Water Sts., Clncinnati, 0. E-48.

Heckex-J ones-J ewell Milling Con, New York City. C-49.

Hickmott Aqparagus Caning $\mathrm{C}_{0_{1}}$ San Erancisco, Cal. D-36.

Horlick's Food Co., Racine, Wls. $B-48$.

Hotaling-Waxnex Co., Syracase, N. Y. A- 47 .

Impexial Granum Co., 153 Water St., New York. F-46.

Johnston, Dx., James, Bralford, Pa. Koumiss. An Interesting collec tion of fermented milk products from many countries; a scientific reproduc. tion of time houored foods. Their sto cessful manufacture demonstrated in America. D-49.

Kato Coffee Co., 15 Wnbush aven Chleago, III. D-45.

Klinek, C., Bufralo, N. Y. D. -46 , Knox, Charles, Johnstown, N. Y. $\mathrm{F}-42$.

Lackawnma Dairy Co., the, Scranton. Pa. $\mathbf{D}-39$.

Libby, MeNell a Lbby, Chicago, III. $\mathrm{H}-45$.

Incharen Imperlal Cheene Coy A. F., Toronto, Ont. B- 48. 
MeCready, Mrs. J. T., 45 E. Utien St., Bufalo, N. Y. B-51.

Mellins Food, Hoston, Mnss. F.44. Mohienn Spring Water Co., Newark, N. J. D-51.

Sational Food Co., I. D. Perky, Trustee, Worcester, Mass. A- 44.

Telson Morris Co., Tha, Union Stock Yards, Chlcago, III. B- -42 .

Chlcago, E. St. Louls, St. Joseph. Beet and pork packers, lard and oll refiners; mutton, canned meats, sausage, beef extract, fertillzers, etc. Thls booth exhlbits the multitidinous products of this huge jacklag concern.

Yeatle, Henry, 37 Wllliam St.,

New York. C-33.

oneldn Commnnity Co., The, Niagara Falls, N. Y. C-51.

oscar Co., The, 106 Hndson st., New York. A-48.

Patent Cereal Co., Henry A. Davis, Utica, N. Y. E-42.

Pllibury-Washbrxn Flour

Co., Minneapolis, MInn. $A-38$.

Innkel Bros., $445 \mathrm{~W}$. Both st., New York, N. $Y$. C -48 .

Saratoga Springs Mineral Water Co., Saratoga Sprlngs, N. Y.

Snuer Co., C. F., The, Richmond, V\&. B-51.

Schwarzschlld \& Snleberger Co. New York, Chicago, Kansas Clty. Ments. Products awarded frst prize and gold medal, Parls Exposition. 1900. Food department, $\mathrm{D}-45$.

smith, Kline \& French Co.. Canal and Poplar St8., Philadelphla, $\mathbf{P a}$.

st. Chnrles Coniensing Co., St. Charles, III. B-49.

Swift if Co., Union Stock Yards, Chlcago, III. G-46.

Wnshbnrn-Crosby Co., The, B44 Prudential Bldg., Buffalo, N. Y. C-38.

Welch Grnpe-Jnice Co.s The, Westffeld, N. Y. E-51.

Wesson Process Co., The, Philadelphia, Pa. G-42.

\section{JAMAICA.}

Bucknor, Thomns H., Kingston, Cassara flour.

Cox., Hon. H. E., Claremont. Ten. Fenrtudo, Joseph. Sauce (unirex-

George Aranday, IKingston, Corfee, cocoa, spices, etc.

Jamnicn Local Commiftee, Kings-

ton. Coffee, cocoa, spices, cereals, etc.
Mraclinalo, B. \& B. I., Kingstun. C1gars.

MeNish Ltd., Kingston. Kola preparations and syrups.

Mornles, Jogeyh S., Spanish Town. Honey. Mason, J. O., Aax Bay. Cocon
spices, etc. Mllle ${ }^{-}$Nephew, J. Christiana.
Ginger.

Noyes, F. S., Port Morant. Cocon.

Pringle, Hon. Dr. J., Annotto Bay. Cocoa, kola powder, cereals, etc.

Prinele, Hon. Dr. J., Annotio Day. Nutmegs, pimento.

Wnlcott, Mrs. G., Kingston. Preserves.

Shirley, Iester Colville, Manenas. Sugar (muscarado). Simon \& Co., Comrad, Kingston.

Wnleott, I. A., Kingston. Snnce (Martha's).

Weasels Nrothers, Tringaton, Coffee, cocoa, kola nuts, splces, etc.

Wray \& Nephew, J., Iringston. Coffee, sugars, rums, etc.

Wynne, W. W. Manderille. Cotfee, splces, etc.

\section{MEXICO.}

Agnixre, Domingo, Tepic. Cane sugar.

Albaitero y Cia, Tacubaya. Flour. D-F.

Albino, Ienndro, Yecapixtla, Morelos. Coffee.

Alfaro, Emifilio D., Chilchotla, Oaxaca. Coffee.

Almada y Hermanos, Jeens, Navalato, Sinalua. Cane Sugar.

Almada y Kcrmanon, Jesus, Nnvalato, Sinaloa. Liquors.

Areiniega, Anrello, Contepec, Veracruz. Coffee.

Arins, Jose C., Chietla, Puebla. Coffee.

Artigna, Gabriel C., San Andrew Tuxtla, Veracrua. Cotree.

Arendano, Antonio, Chilehotia, Oaxaca. Coffee.

Ayrizo, I., Inquila, Oaxaca. Coffee.

Mall, Jnan W., Dnrango. VInegar.

Bamo, Eagento D., Chirchotia, Oaxaca. Coffee.

Becerra, Fubre. Belimarlo, san Juan Bautista, Tabasco. Collee and cocoa. 
Bentley \& Harris, Colonin ,Innrex, Galeana, Chihuahur. Preserved fruits.

Cafetal, Santingo, Chilchotin, Oaxaca. Coffee.

Camacho, Ismael, Quechula, Chiapas. Cotfee and cocoa.

Camacho, Timoteo, Queretaro. Liquors. Campos, Ricardo M., Tapachula, Chiapas. Coffee.

Cano, Modesto, Quechula, Chinpas. Coffee.

Cattucel, Horacio, Xalapa, Veracruz. Órange wine.

Cervantes, Jextumentaria de M., Mexico. Flour. D-F.

Compania Cervecera de Chihnahua S. A., Chlhuahua. "Edelweiss," "Exposiclon" and "Carta Plata" beers.

Comprnia Destilauora "Cara Colorada," Mexico. Liquors. D-E.

Conipania Destilatorn, Mexico. Alcohol. D-E.

Companin Destiladora, Mexico. Liquors. D-F.

Compania Industrial, Mermosillo, Sonora. Starch.

Cordorn, Fenerico, Zncunitipan, Hidalgo. Liquors.

Cortes, Anselmo, Veracruz. Cottee.

Cuesta Gallarao e Hijos, Mnnuel M., Atequiza, Jalisco. Alcohol.

Diar, Anrelio, Qneretaro. Quince wine.

Diaz, Ordaz $y$ Cia, Chilehotla, Oaxaca. Coffee.

Donde, waurdo, Contepec, Veracruz. Coffee.

Escudero, Francinco, Tepie. Corfee.

Equeron, Manuel, Chilchotia, Oaxaca. Córtee.

Fabricn de Cerveza, "Fl Ieon," Leon, Guanajuato. "Book" and "Peria de Oro" beers.

Finca, Eaperanya S. A., Teotitian, Oaxaca. Cotree.

Finca, Merceles, Teotitian, Onxaca. Coffee.

Flor, Jose, Jalapr, Veracrnx. Chocolate.

Fuentes Solia, Fernnndo, Zreanltipan, Hidalao. Quince wine.

Gaino, Salvaior, Mexico. Vinegar. $D-F$.

Galiein, C., Pucbla. Oxange rine.

Galvez, A., Contepec, Verneruz. Liquors.

Garcin, Jonnuin, Texcoco, Mexieo. Liquors.

Garcia, Maxiano, ChllchotIn, Onxaca. Corfee.
Gareia Pimentel, Luis, Sta Clate woez, $\mathrm{F}$ Jinacatepec, Morelos. Cane sugar, Gobierio del Estado de Agar. willon
callentes. Flour.

Gobierno del Estado de jero calientes. Red pepper. ie Agan. ynnel

Goblerno del Gstado de chlcho Tuxtla. Coffee and cocoa. Chapa, yartin

Gobierno del Gatailo de Chlapal flout Tuxtla. Spices.

Gobierno del Estado de Dnrango Liqu Agave syrup.

Goblerno ilel Fintado de nom Bee honey.

Gobierno del Estrido de Doran Nuts and plue nuts.

Goblermo del Estado de Jalloco cho Guadalajara. Brown sugar. Jalisen, yerc

Gobierno del Estndo de Jalloc Bie Guadalajara. Coffee.

Goblermo del Estado de JaHsco Guadalajara. Green pepper. Wes

Gobierno del Astado de Michos. can, Morella. Coffee. yet

Goblerno del Costndo de Morclos, Cuernavaca. Cane sugar.

Goblerno del Estado de Morelos, 10 Cuernavaca. Coffee.

Goblerno del Estado de Oaxaca. Coffee.

Gobierno del Estado de Prebla Cottee.

Gobierno del Estrac de quere. taro. Coffec.

Goblernn del Estndo de San Lofs Potosl. Coffee.

Gobiexno del Estrio de Tobasco, San Juan Bantista. Mushrooms.

Gobierno ael Entado de Tabarco. San Juan Bautista. Tea, coffee and cocoa.

Giobierno del Estado de Tinxeria. Red pepper.

Gobierno iel Fontado de Veracrus, Xalapa. Coffee.

Gomez Vargas, Rafael, Cordora, Veracruz. Coffee.

Hernandez, Augastin, Chlos, Chiapas. Coffee.

Ifinigo, Gnmersindo, Mesteo. Starch. D-F.

Jarilla, Fmiliano, Pahuntlan, Puebla. Coffee.

Juspeado, Nuperto, Jexcoco. Mexico. Ollve oll.

Jaspeado, Rnperto, Tezcoco, Mex. 1co. Agavino.

Jefatura Pointien del Territorlo de Teplc. Coffee.

Lastinere, E., Prebla. Ginger alc and sarsaparflla. 
The Pan-American Oficial Catalogue and Guide.

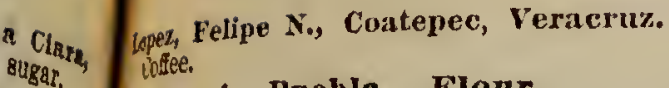
Aguar. Lotenz, A., Prebla. Flour.

yaldonado, Ramon, Monterrey,
Jiero Leon. Liquors. yantel, Ponciano, Tacambaro, ylchoacan. Coffee.

yartiner del Cerro; J., Tacubayn. Flour. D-F.

yartinez, P., Zacntlan, Puebla. Liguors.

yena, Evristo, Campeche. Maranon wine.

yendex, Eplfanio, Guadalajara, Jalisco. Cane sugar.

yerendo, Arimteo, Uraapan, MLchoacay. Coffee.

yerendo de Romano, Leonor, San Blag, Teplc. Coffee.

yerino, S., Miznntin, Veracrux. Mizantleca sauce.

Verdean Gulf Agricultaral Com pany, Dos Rios, Veracruz. Coffee.

Jera y Cla, Mogrovejo Anerctaro. Qulace wine.

logrovejo, Juan, Calnall, HAalgo, Orange wine.

yoral, Tomns del, Tolncn, Mex100. Liquors.

Ioreno, Andrew, Amilelngo, More108. Coffee.

Vortega Samano, Alonno, Mexico. Chocoiate. D-F.

Inaniclpio de C. Gnerrero, Tamauipas. Agave syrup.

ochon y Avilez, Fuerte, Sinaloa. Llquors.

olguin, Estanislao, Calnail, H1dalgo. Coffee.

Park y Bergote, Chllchotla, Oaxaca. Coffee.

Pendas, Manuel, Ze cualtipan, Hidaigo. Quince wine.

Perez Arce, Carlos, Guadalajara, Jalisco. Sago.

Perez, Arce, Gandalajnra. Jalisco. Ginger ale.

Perez, Aurello, San Jome Purua, Michoacan. Coffee.

Perez, Jose, Cnilapan, Oaxaca. Nuts.

Popoca, Refuglo, Tilapa, Puebla. Coffee.

Portillo, J. O., Ch1lchotla, Oaxaca. Coftee.

Pradillo, Agustin, Teotitian, Oaxaca. Coffee.

Ramirex, Tomas A., Molango, IIdalgo. Liquors.

Regnles, Hermanos, Chilohotia, Oaxaca. Coffee.
Rinaelme, S., Mexico. Pulque. $D-F$.

Rivero Suces, V., Monterrey, Nuevo Leon. Malcena.

Rodrignez, Mnrinno, Patzcuaro, Michoacan. Coffee.

Rodriguez, Inmon, Queretaro, Alcohol.

Rojas, Ponctano, Picbnenleo, Chiapar. Cocoa.

Royns, Justo, San Junn Barieta, Tabasco. Coffee.

Suntr Cruz, Francisco, Collma. Alcohol.

Santa Cruz, Francisco, Collma. Coffee.

Secretaria de Fomento, Mexico Coffee and cocoa. D-F.

Sociedad Agricola Mexicana: Mexico. Aicohol. D-F.

Soctedad Agricola Mexicana, Mex. Ico. Cane sugar. D-F.

Socledad Agricola Mexicana, Mex1co. Coffee and cocos. D-F.

Socledad Agricola Mextcana, MexIco. Nuts and pine nuts. $D-F$.

socledad Agricola Mexicana, Mexico. Red pepper. $\mathrm{D}-\mathrm{F}$.

Solorzano, Ildefonso, Treambaro, Michoacan. Cotfee.

Solorzano y Sanz, J., Merlco. AIcohol. D-F.

Sousr Rodrignez, Junn, Acaponeta, Tepic. Liquors.

Subprefectirn de los Munictptos de San Jose y Santlago, Baja, Cailifornla. Cane sugar.

Tardon e Hijos, Julio, Mextco. Vinegar. D-F.

Tellez, Antonio, Huanchinango, Puebia. Cotree.

Tellex, Antonio, Villa Juarea, Orxaca. Coffee.

Tromblin Brijan, B., Cordova, Veracruz. Cotree.

Ugnide, Agriplno, Zacualtipan, Hidalgo. Orange wine.

Uribe, Macedonio, Texcoco, MexIco. Orange wine.

Vargas, M., Collma. Liquorm. M., Atequiza, Jalisco. Alcohol.

Vazquex, Jose G., Ayotla, Mexico. Olive oll.

Velez Arriagn, Luin, Soconnnco, Clapas. Cocoa.

Voguel, Arnolido, Colima, Alcohol.

Voguel, Arnoldo, Colima. Coffee.

Zaragoza, Sunton, TIalnepantla Cuautengo, Morelos. Coffee.

Znniga, Adalberto, Hnamalingo, Hidalgo. Cotree. 
GATALOGUE OF THE FLOUR EXHIBIT OF THE ARGENTINE REPUBLIC.

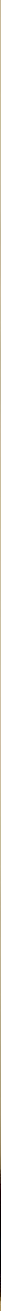


CATALOQUE OF THE FLOUR EXHIBIT OF THE ARGEWTINE REPUELIC-CONTINUEO.

\begin{tabular}{|c|c|c|c|c|c|c|}
\hline & No. & EXHIRTTOR & & NABE OF THE MILL. & A DORESS. & PRODUCT. \\
\hline * & $\begin{array}{l}42 \\
43 \\
44 \\
45 \\
46 \\
47 \\
48 \\
49 \\
50 \\
51 \\
52 \\
53 \\
54 \\
55 \\
56 \\
57 \\
58 \\
59 \\
60 \\
61 \\
62 \\
63 \\
64 \\
65 \\
66 \\
67 \\
68 \\
69 \\
70 \\
71 \\
72 \\
73 \\
74 \\
75 \\
76 \\
77 \\
78 \\
79 \\
80 \\
81 \\
82 \\
\end{array}$ & 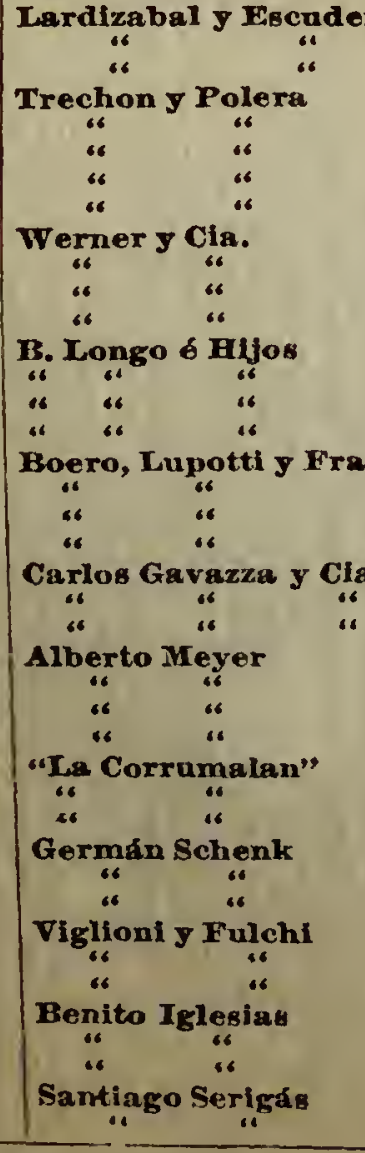 & 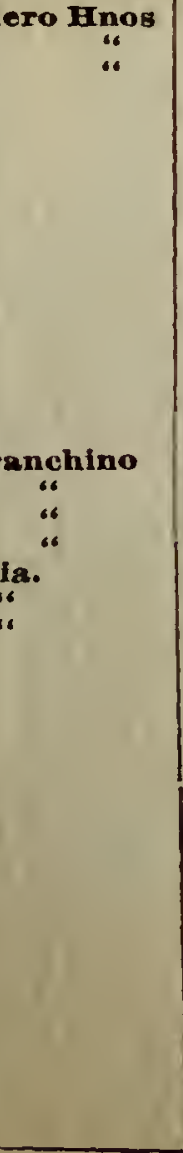 & 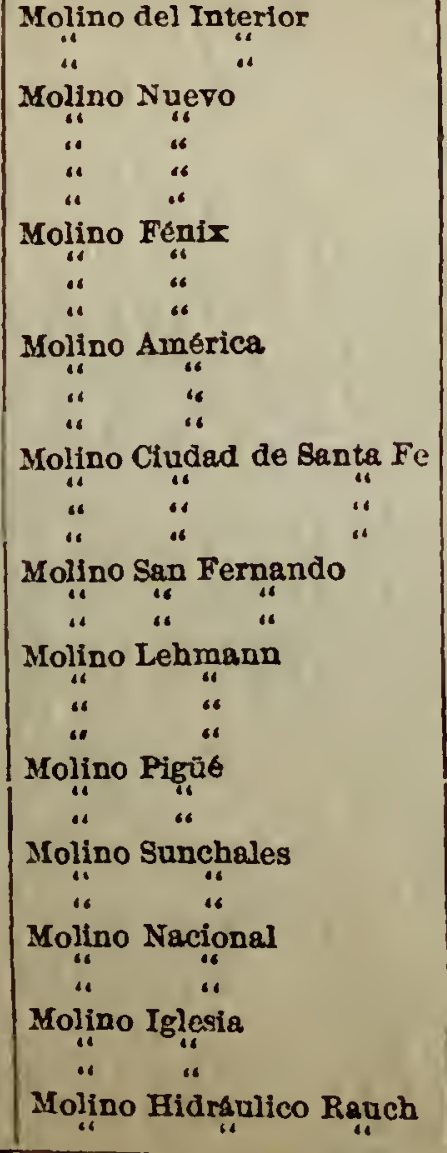 & 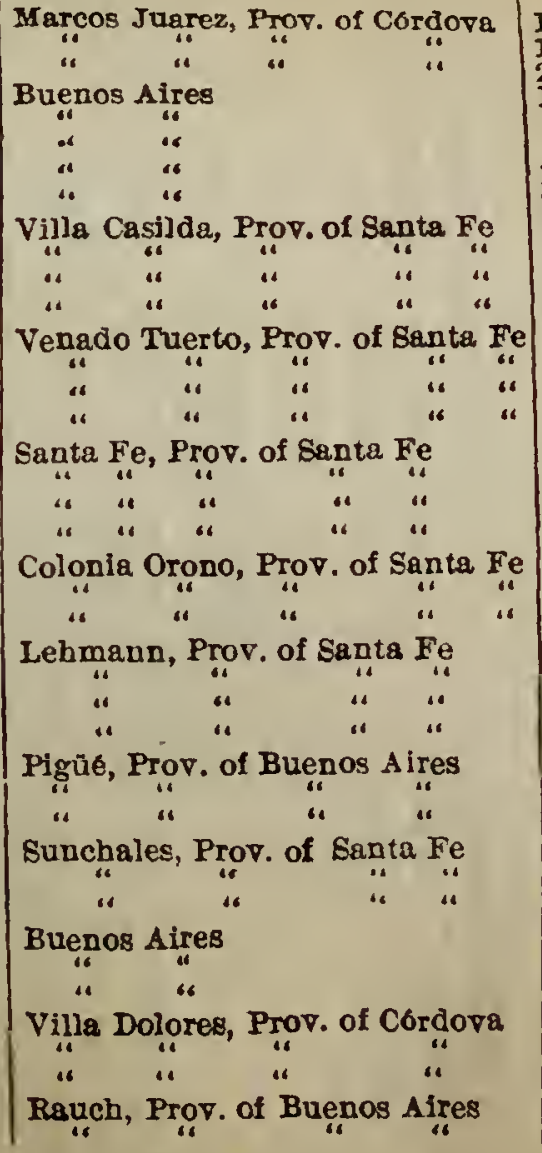 & 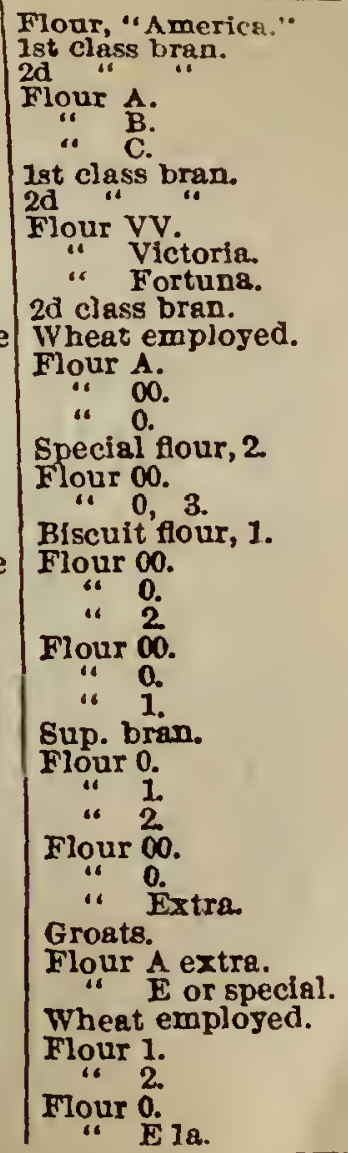 \\
\hline
\end{tabular}




\section{Manufactures Pergola (or Annex).}

Algan. Maheeler, Supt.

This is an annex to the Manufactures and Liberal Arts Bullding and is located at the eastern end of that building, separated from the same by the Canal.

\section{EXHIBITORS.}

Abendroth Bros.. 100-11t Beekman St., New York City. Gas stoves and steam and hot water heaters.

binney \& Smith, 81 Fuiton st., New York, N. Y. Stenclls.

nine Ridge Enameled Brick Co. Newark, N. J. Enameled brlck and tlle.

Burrowen Co., The w. T.. Portland, Me. Wire sereens and bliiiard tables. $A$ fine Combination Portable Table or Board with 16 bails, cues, etc., 40 parts, for $\$ 15$ to $\$ 25$. Take one home. Look at our exhlbit. Also wire screeng for fine houses.

Canflela Rubber Co., Brijgeport, Conn. Crude rubbers.

Castmer Electrolytic Alkali Co., Niagara Falls. N. Y. Sait and heavy chemicals. Salt, soda, ash, caustic soda (aii strengths), caustic ilquor, lye, blcarbonate of soda, bieachlng powder ln air tlght steel drums, electrozone the unexcelled dislnfectant.

Cosmonolitan Range Co.. 28 Snlllvan St., New York, N. Y. Ranges.

Felton, S. A. Son Co., Mnnchester, N. H. Power and hand brushes.

Frees, C. A., New York. Artificinl llmbs.

Gan Appliance Mrg. Co., 207 St. James St., Montreai. Canada. Gas furnaces.

Gloncester Fisherien, Gloucester, Mass. Fishery exhiblt.

Mirmehield, Ruth Ashley, $210 \mathrm{~W}$. 88th St., New York, N. Y. Model uur-
sery.

Jewett
Stores.
Koven Bros., 50 Cliff Si, Vet York, N. Y. Tanks, boliers, etc.

Kelney Furnace Co., Syracuse, 1 Y. Furnaces.

Mattheson, Wm. J., 182 Front sh New York, N. Y. White lead.

Mathieson Alkall Works, The Saltrille, Va.

Mechanieal Acconntant $C_{0}$, Providence, R. I.

National Leather Co., Philadel. phla, Pa. Leather mats.

Parker, Geo. W., Daubury, Cona. Pottery.

Rendle, A., New York, X. Y. Bkg llghts.

Richter Mrfg. Co., Terrafiy, X., Burlaps.

Roberts Mig. Co., Philadelphta, Pa. Water filters.

Schoellkopt dE Co., Buffalo, Ni. $\tau_{1}$ Sheep ieather.

Schoellkopf \& Sons, J. F., Buftalo, N. Y. Cut sole leather.

Swett Iron Works, A. Lo, Medlan, N. Y. Heaters.

v. S. Lenther Co., 28 Ferry 8t, New York, N. Y. Leathers.

United Indurated Fibre Co., Lock. port, N. Y. Domestlc ware.

Vacuum Oil Co., Rochester, N, I, Leather olls.

Wiggins Sona, H. B., Bloomfleld, N. J. Burlans. Are coiored woven fabrlcs, both plitin and figured. with the FAB-RI-KO-N, (Trade Mari) backing, so that the goods can be hung like wali paper. Elegant effects. 


\section{Heetylene Building.}

LIGHTED BY ACETYLENE GAS.

Algar M. Wheeler, Supt.

Office: East Gallery, Manufactures Building.

\section{EXHIBITORS.}

Abner Acetylene Gan Co., Ch1cago, Ill. Generators.

acetylene Jonrunl Publinhing Co., 324 Dearborn St., Chicago, III.

deetyrone Mfg. Co., New York, N. Y. Generators.

American Acetylene Bnrner Co., Rochester, N. Y. Acet. gas appliances.

American Carblde Lamp Co., 384 Bourse, Phlladelphia, $\mathbf{P a}$.

Brace-Cram Generator Co., Brooklyn, N. Y. Generators.

Central United Acetylene Co., Plttsburg, Pa. Generators.

Colt \& Co., J. B., 108 Fulton St., New York, N. Y. Generators.

Duncombe, F. H., St. Thoman, Ont. Generators, house and car light: lng firtures.

Eagle Generator Co., st. Louis, ifo. Generators.

Electro Lnmp Co., 45 Broadway, N. Y. Acet. gas appliances.
Fintan Green House \& Car Lighting Co., St. Louls, Mo. Generators.

Kinnenr Mfg Co., Warren, Pa. Generators.

Kirchberger \& Co., M., 50 Warren St., New York City.

Miller \& Co., Eiward, Meriden, Conn. Acet. gas appllances, etc.

Pan-American Acetylene Co., Bnffalo, N. Y. Generators.

Sunlight Gas Machine Co., The, 208 Greenwich st., N. Y. Generators. 'The "Sub-Marine" Acetylene Gas Gienerator is never opened, insuring absolute safety. Gas purified in large volume of water. Perfect generation guaranteed at lowest cost.

State Line Mrg. Co., Chattunooga, 'Tenn. Generators. $\boldsymbol{U}$. M. Steward's patent burners, Wonder, Acme, Meteor, New Century, Stereopticon, and Argand burners.

Union Carblde Co., 157 Mlchtgan Ave., Cnicago, III. Acet. gas appliances.

\section{Mission Bailding.}

Special building, located just north of the Dairy Building.

Aeollan Company, 18 W. $23 d$ st., New York, $N$. $Y$. The Aeolian plpe organ recitais will pe atven dally in the J. K. Lamb Mission C'napel. Admission witl be tree.

Birge \&ons Co., M. H., Bufalo, N. $Y$. Yaper hangings.
Bufialo Pits Co., Bafialo, $X . X$. Agricultural machinery.

Lamb, J. \& $\mathbf{n}$. New York. N. $Y$. Memorial and ecclestastical art work. Inspect examples in the Sprague, Birge and Lamb Mission Chadel, at the Exposition. 


\section{Machinery and Transportation Building.}

Thomas M. Moore, Sup't.

KEY TO INSTALLATION.

For the purpose of conveniently locating the exlibits, the ground floor plan (1 the building (see opposite page) is divided into sections, which are indicated $y$ the letters $A$ to $V$ in one direction and the figures 1 to 26 in the other. $B y$ "is system each exhibit has a position of latitude and longitude. For example, gn exhibit marked " $\mathrm{O}-13$ " would be found at that point where a line drawn iertically from " 13 " intersects a line drawn horizontally from " 0 ."

\section{NATURE OF EXHIBITS.}

Engines and Boilers, Gas Engines,

Valves, Pipes, Castings, Tools, Lathes,

villing Machines, Elevating Machinery, Fans, Blowers, Pumps, etc., Bicycles, Automobiles, Locomobiles, Wagons,

Carriages, Coaches, Buggies, etc.

\section{EXHIBITORS.}

\section{MACHINERY.}

Abendroth \& Root Mfg. Co., Nev York, N. Y. Boller. M-3.

scme Inchine Screw Co., Hartford, Conn. Screw machines. $0-4$. Alberker \& Son, Bufinlo, N. $\mathbf{Y}$. Gas engine. L-8.

Alexander Bros., Philadelphia, Pa. Leather belting. $N-18$.

imerican Blower Co., Detroit, Mlch. Blowers, fans, etc. $M-6$.

Branches: New York, Chicago. and London. Manufacturers - Blowers, Engines, Special Dryers, Heating Apparatus "Molst Alr" Lumber Dry Klins, "Waste Heat" Brick Dryers, Expert Heating, Ventliating, and Drying Engineers. Submit jour difficult problems to us.

American District Steam Co., Lockport, N. Y. $0-1$.

Orlginators and bullders of Holly system of underground steam distribution. Two hundred steam plants in operation. Also manufacturers of all kinds of steam speclalties.

American Engine Co., Bound Brook, N. J. Engine in Power Plant.
American Brachine Co., The, Buffalo, N. Y. Machines of wonderful interest to millers. The ultimator sifting machine and the WInkler elevator bucket. Manufactured by the Amerlcan Machine Co., 357 Seventh St., Buffalo, N. Y. Wm. B. Jackson, Pres., H. R. Kenyon, Sec., H. H. P'ersonB, Treas. $\mathbf{P}-3$.

American Pnlley Co., Philadelphia, $\mathrm{Pa}$. Pulleys. $\mathrm{N}-8$.

American Steam Gange ro. Jamalca PI., Boston, Mass. Valres, gauges, etc. $S-8$.

American Steel and Wire Co., Worcester, Mass. Steel and wire goods. J-21.

American Tool and Machine Co., Boston, Mass. Sugar machinery. B-3.

Engineers, founders and machinists. Founded in 1845. Incorporated 1864 Specialties : Weston centrifugals, hy. dro-extractors, lathes, belt knife, spilit. ting machines, Improved Worrall Irictlon clutch couplings and pulleys. The leading buliders of sugar machlnery in the world. 
Amertcan Tool Works, Cincinnati, 0 . Tools, etc. 8-P.

Ames Iron Works, Osvego, $\mathbf{X}$. Eugine. J.-15. Power Plant.

Andergon Bron, Pateraon, N. $x$. Silk loom. $\mathrm{D}-10$.

Atchimon, Topelin \& Sunta Fe Rallway System, The, Chicago, Ill. Vlews.

Atkins \& Co., E. \& C., Indianapolis, Ind. Circular tools, saw tools. N-15.

Solld and Inserted tooth clrcuiars, veneer, shingle, serment, band, crosscut, hand, wood, kitchen, pruning and compass saws. Corn, cane and beet knives. Machine knives a speclalty.

Atlas Pipe Wrench Co., Nerv York City. Pipe wrenches. P-1.

Anstin d Eddy, Boston, Mass. Sanding machine. $R-10$.

Ball Engine Co., Grie, Pa. Engines. H-8. Puwer Plant.

Barnes Co., Rockford, 11. Water Tool grlader. $\mathbf{P}-8$.

Banhin \& Co., Warren, Pa. Valves. S-4.

Benttle \& sons, Cohoes. N. $\mathbf{Y}$. Collar machines. $\mathbf{F}-7$.

Becker-Bratnari, Hyde Park, Mass. Milling machlnes. Q -18 .

Bell Engineering Works, The David, Buffalo, N. Y. Steam hammers. $\mathrm{M}-22$.

Belmer-Eames Tool Co., Cincinnati, 0 . Model pianers. $R-17$.

Bensemer Gas Engine Co., Grove City, Ia. Power Plant.

Blekford Drill o Tool Co., Cincinnati, Ohlo. Drils. $0-11$.

Bickford Erancis, Infalo, $\mathbf{N}$. Belting. $N-11$.

Bierbaum a Merrick Metal Co. Butfalo, N. Y. Lumen metals and bronzes, $\mathrm{p}-26$.

Blia \& Co., E. W., Hrookign, $N$. Y. Power presses. $R-21$.

Blodget Mfg. Co., Rochester, N. $X$. Gauges, etc. Q-26.

Bonton Belting Co., Boston, Mass. Mechanical rubber goods. N-19.

Bradiord Belting Co., Cincinnat, O. Beiting. $\mathbf{P}-8$.

Bradford Machine Tool Co., Cincinnatl, 0 . Machine tools. $N-7$.

Brown \& Sharpe Mfr Co.. Providence, R. I. Tools, milling machlnes, etc. $Q-16$.

Anfialo Emery wheel Co., Rnfalo, N. Y. Emery wheels. A-5.
Bufinlo Forge Co., Bnftalo yctit Blowers and englues. $G-6$.

Hufinio Meter Co., Bufralo, X. Y, Water meters. $\mathbf{N}-4$.

Bullders Iron Foundry, Provi. dence, R. I. Meters, machinery, etc.

Bullard Machine Tool Co.. Brldgeport, Ct. Machine tools. $\mathrm{R}-10$.

Bnrr Mig. Co., Clevelnud, Ohio, Safety lifts. $\mathrm{N}-7$.

Burt Manufacturing Co., Alcron, o. Oil filters. In Power Plant.

Cameron Stenm Pump Co., $A_{0} s$. New York City. Pumps. The "Cam. eron." of superlor design and best construction. In iiberal use the world over; conceded to be the most durable, rellable and eftectlve steam pump on the market. $K-4$.

Carborundum Co., The, Magara Falls, N. Y. Carborundum wheels. S-17.

Carborundum is guaranteed to be the most efficient and economical grinding and polishing materiai in exlstence. It is adapted for all classes of work.

Cataract Tool \& Optical Co, Bul. falo, N. Y. Lathes. $P-7$.

Chandler Co., Ayer, Mast, New York office, 11 Waverly Place, Accordion side, and box plaiters; siugle double and triple rose ruchers; box plait ing shirrers, box plaiting bosom machines We are constantly adding special ma. chines, all of whlch are invented and manufactured by us, and ail of whlch we absolutely guarantee. $\mathrm{F}-8$.

Chapman Double Ball Bearing Co., Boston, Mass. Bail beariogs. E-17.

Chester, Allen, Paterson, N. J, Sllk looms. $\mathbf{P}-7$.

Chlcaso Belting Co.. Chteago, 11. Leather beiting. $\mathbf{M}-17$.

Chisholn e Moore Mrg. Co., The, Cleveland, Ohlo. E-5.

Manufacturers of pneumatic and hand power cranes, chaln hoists and trol. leys; pneumatlc hoists and motors; pneumatic tools, malieable Iron cast. ings; Amerlcan standard rall jolnts.

Cincinnati Mrachine Tool ro., Cincinnati, 0 . Drills. P-8.

Cineinnati Millug Machine $\mathrm{Co}_{4}$ The, Cincinnat, Ohlo. Milling ma. chines. We exhibit entlrely new pattern machlnes. See our new all-gear feed mechanism. No belts to slip, no pulleys to shift, no gears to trans. pose. $\mathrm{P}-10$. terello derel derel: land, the.

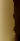


The Pan-American Official Catalogue and Guide. Mocinnati Planer Co., Cincinnati,
oblo. Planers. 0-9.

dieveland Machine Screw Co.

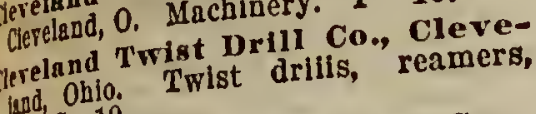
etc. $s-19$.

nereland Wire Spring Co., Cleveland, 0. Spring goods. N-8. Stat Mire Springs, Steel Hods, Wall ries, Yortar and Drili Tubes.

Cllif \& Gribert Co., New York, N. I. Hose reels.

cllng-Surface MIf. Co., Bufialo, X. Y. Cilng-surface. $\mathrm{N}-19$. 19 method Exhibit showing improved. P. motor, transmittlng pow dynamos. Tight belt two tire Ha slack belt full of cllnghilfice.

Clonbrock Boller Co., Brooklyn, N. צ Boilers. In Power Plant.

coates Clipper Mre. Co., Worcester, Jass. Clipper. $\mathrm{H}-22$.

cochrane Co., Lorain, Ohio. Retrigeratlng machinery. $\mathrm{P}-4$.

coe Mig. Co., Painesville, ohio. Veneer machine. $\mathbf{R}-8$.

contractors' Plant Mfr. Co.. Buttalo, N. Y. Hoistlng engines. C-5. Cornell, J. B. \& J. M., New York City. Fans, blowers, etc. H-5.

corel Mfg. Co.. Chicngo, I11., U. S. A. P-6. Saw machlinery. Saw sharpening and saw fitting machinery of every descrintion. Write for lliustrated catalogue.

Crocible Steel Co. of America, Pittsburg, Pa. P-5. Cruclbles.

Conningham Mfg. Co., Philadelphia, $\mathrm{Pa}$. Sterilizing machine. C-4.

Cyclone Grate Bar Co., Toronto, ont. Grate bars. E-1.

Denne Steam Pump Co., Iolyoke, Mass. Steam pumps. K-5.

Detrick \& Harvey Machine Co., Baltimore, Md. Tools. Q-21.

Dlamond Drill \& Machine Co. Birdsboro, $\mathrm{Pa}$. Drills, crushers, etc. $0-9$.

Diamond Machine Co., Providence, R. I. Grinding machincry. S-18. Dodge Mfg. Co., Mishawara. Ind. Power transmlssion machlnery. P - 13 .

Dolg, Estate of Willinm S., Brooklyn, N. Y. Box nalling machlnes. Manufacturers of standard box nalling machlnes, speclally adapted to meet the various needs of packers and bos makers. $\mathrm{R}-\mathbf{6}$. D'olier Enginecring Co." Phila-
delphia, Pa. Swltchboard. In Power Plant.

Dresser, S. R., Bradford, Pr., F-2. Oil, gas and water line speciaitles. Oil, gas and water Co.. Waterford. N. $Y$.
Edidy Valve Cower Plant.
Valves. In Pork

Gurela Fire Hose Co., New York City. Fire Hose. O-26. This company was oldest and largest 1875 and are the fre hose in the U. manufacturers oL al manufacturers of S., also the original manued fre hose; seamless cotton rubserion.

hose of every descrlpefribatior Co., Eyswen Packer. Strlpplng machines $\mathrm{N}-4$. N-4.
Farionks Co. Buffalo, N. $Y$.
Valves. In Power Plant.

Fanenil Watch Tool Co., Boston, Mass. Lathes, grinders, etc. Q-9. Fay \& scott, Dexter, Ma., Serew cutting lathes. P-8. Fayerweather \& N-15.

York City. Belts. N- Co., Bridgeton, N. J. Mamp Co., Luckport, Field Force Pump. D-23.

N. Y. Force pumps. Engine Co., Fitchburs Stenm Engines. J-14. Fltchburg, Mass. Eng Co., SpringFoos Mannfacturises, etc. C-4. field, Ohio. Gas enginechester, N.

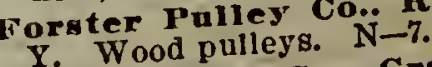

Y. Wood pulleys. Na., Grand Rapida,

Fox Machine Co., Grand machinery. Mich. Wood-working

P-17. Muey Co., Falton, N. $\mathbf{Y}$.

Fuiton Pulies $\mathrm{N}-10$. Giena Oil Co., Franklin, Pa. N-2. olls.

Gnrlock Packing Co., Palmyra, N. Y. Packlng. Q-1. Co.. Mradmon, Gisholt Machine poip. Wls. Lathes, etc. A. Cincinnati, Gray \& Co., G. A. Ohlo. Planers. Q-19. Green Fuel Fconomizer ro., $0-3$. teawan, N. Y. Co., A. A., Jermey Grifing Iron Co., A. A..jo Jes. In Clty, Plant. Guild \& Garrison,

Y. E-3. Steam por Lockort, N. Y. Hall Iron works, lupplies, etc. D-1. Pumps, machineryono, IIl. Olls. Yanun OHl Co., A-5. 
Harriabarg Foundry \& Nnchine Works, Harrisburg, Pa. Stationary engines, englnes, hlgh and medlum speed, self-olling, automatlc, single and fourvaive. Aiso improved Corliss with steam accelerated valve gear. In Power Plant.

Farrison Safety Bollex Workn, Phlladelphla, $\mathrm{Pa}$. Feed water heatera separators. I-8.

Hay Budden Mfg. Co., Cleveland, Oblo. Anvils. $\mathrm{R}-23$.

Heald L. S., Barry, Mass. Twist drlll grinders. $\mathrm{R}-16$.

Hendry Machine Co., Torrington, Conn. Lathes. $\mathbf{R}-8$.

Hickman, Mellorn \& Co., Pittuburg, Pa. Plpe threading machines. A-5.

Hofele, F. W., Fort George, N. X. Fire apparatus. $P-26$.

Hogrson \& Pettis Mfg. Co., New Haven, Conn. Chucks, tools, etc. Q-26.

Holmes Machine Co., E. \& B.. Bnifalo, N. Y. Wood working machlnery. Q-9.

Hownrd Iron Works, Buffalo, N. Y. Elevators, presses, etc. B-3.

International Time recoraing Co., New York Clty. Time recording machines. $\Delta-18$.

Jacolowon Maehine Co., New York, N. Y. Steel pulleys. $\mathrm{N}-9$.

Jenkins Bros., 71 John St., New York, N. Y. Valves. Manufacturers of Jenkins Bros. valves for steam, water and gas: Jenklns '96 packing, discs, pump valves, gaskets, gasket tublng, etc. Sellers restarting injectors. $S-4$.

Jenngst \& Sons, Geo., Groton Falls, N. Y. Shapers. $0-7$.

Keasbey Mattison Co., Ambler, Pa. Pipe and boller covering. In Power Plant.

Kelly Bros Spielman, Philadelphia, $\mathrm{Pa}$. Belt lacing machines. $\mathrm{N}-7$.

Kennody Valve Co., New Tork City. Valves. S-4.

Kensington Engine Works, Philadelphia, Pa. Valve regulators. Power Plant.

Keystone Electric Co., Erie, Pa., Generators. In Power Plant.

Kieley \& Mueller, New Tork City. Steam specialties. $S-6$.

Knowles Steam Pump Co., New York, N. Y. Pump. Pumping drinking water in Electric Tower.

Knowlton \& Beach, Rochester; N. $\mathbf{Y}$. Paper box machlnes, $\mathbf{P}-6$.
Iamb \& Ritchle, Cambridgengte If Mass. N-4. Tin lined wrought Iron plpe; les wrought lron plpe. To avold lal brass polson in water block tis wrought Iron plpes are melte gether. They cannot beite! : waston even by bending or hot wapris if

Landis Tool Co., Waynesbore, yont Gulding machines. $19-\mathrm{p}$.

hancaster Mnchine \& Knlfe $c$ Lancaster, N. Y. Knives. S-2L, II.

Lane \& Bodley, Cincinnat, Olh, istoo Englnes. K-17:

Laziex Gas Engine Co., Butiala I Y. Gas engines. Power Plant. I. 'gare:

Lidgerwood Mfg. Co., 90 Libert intios St., N. Y. Hoisting engines (tzan robl and electric) for all holsting purgen Over 17,500 in use. Cableways, ing and conveying devices for mi: quarrying, logging, dam construe etc. The Marlne Cableway. The pld unloader for ballastlug rallioa:

Lodge e Shipley, Cincinaath 0 . Engine lathes. $\mathrm{P}-9$.

Long \& Allwtater, Hamilton, Oar Machlnery. N-22.

Wunkenheimer Co., The, Cinel. nati, Ohlo. Valves, etc. Sole maly and patentees of brass and Iron ralrs whistles, lubricators, injectors, cots oll and grease cups, and englneer's appliances of superlor quallty. Wits for catalogue. $L-5$.

Mnchinist Supply Co., Rochenter. N. Y. Wood pulleys. N-7.

Manion Optical Co., Buffalc, X. T. Optlcal goods. $\mathbf{P}-\mathbf{T}$.

Mnrinette Iron Work. Mig. Co. Marlnette, WIs. EnglBes. J-8, i: Power Plant.

Mrerrill Mfg. Co., Toledo, Obla Pipe threading and cuttlng machlos Q-10.

Mertz Sons, Geo., Port Chester, N. I. Wood mouldings. N-23.

Midgley \& Thompson, Bufialo, N, I. Automatic fire alarm. $\mathrm{P}-26$.

Mietz, August, Now York, N. I. N-6. Gas and kerosene engines.

Mine \& Smelters' Supplies Co. Mining machinery. $\mathrm{O}-25$.

Monarch Fire Appliance Co., Ne York, N. Y. Fire extingulshers. $\mathrm{C}-24$.

Monarch Mfg. Co., Waterbur, Conn. Engine stop system. Pore' Plant.

Morris Machine Works, Baldwins ville, N. Y., U. S. A. Pumps, ets L-4.

Centrifugal puraplng machinery. 0lo est and largest concern of 1 it bind in America, 
Fidsther wsye Inlst Drill Co. New Bed-

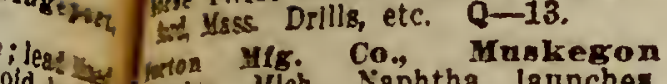

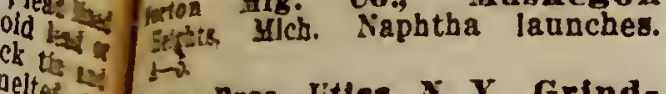

deltef tow Bros. Utiea, N. Y. Grinder.

Irras Iron Works, Barlington, If Engines. J-18. In Power Fistic

Ca, wath Englne Co., New York, II. In Porer Plant. Gas engines. istoral Meter Co., New York Co. Yyeters. I-4.

Jutoual Pipe Bending Co., New garea, Conn. Pipe machlnes. Q-1. sotoan Tube Co., Pittaburg, Pn. Toblag, etc. $\quad K-2$.

Sesmes Bros., Troy, N. Y. Shaktor grate. C-1.

Ter Tork Belting and Packing Coy $\mathrm{S}_{\mathrm{H}}$ Iork, N. Y. Rubber belting. is. 18.

Str York Leather Belting Co., SeF York City. Belting and lace mods. N-18.

Pusara Machine \& Tool Co., BneLlo, X. Y. Tools. O-23.

Iller-Bement-Pond Compnny, 136 asd 138 Llberty St., New York, N. Y. Tools, Irod working machlnery. L-23.

Yoera Mis. Co., Waterbary, Conn. $\Delta-5$. Hardware and blcycle specialthes.

Sorton Emery Wheel Co., Worcester, Mass. Emery wheels. R-15.

Sorrotony, John S., Electric Co., Cinclunati, Ohio. Motor. P-24.

ollier Mfg. Co., Bufalo, N. $\mathbf{x}$. Dentsl machlnery. N-25.

omey, Warren, Bufralo, N. Y. Fire escape. $\$-5$.

Ouelda National Chuck Co., One1da, N. Y. Chucks. P-26.

Onelda Steel Pulley Co., Onelda, N. Y. Pullers. N-10.

Onondaga Dynamo Co., Syracuse, N. Y. Dynamos, motors, etc. J-16. Otto, Albert, New York, N. Y. Torning machine. B-6.

otto Gas Engine Works, Philadel$\mathrm{phla}, \mathrm{Pa}$. Gas englnes. $\mathrm{R}-7$.

Pfandler Vacuum Fermentation Co., Bochester, N. Y. Beer tanks.

Phlladelphin Pnenmatic Tool Co., Phliadelphla, Pa. Pneumatic toois. $\mathrm{C}-5$.

Pittuburg Meter Co., East Pittsburg, Pa. Meters. Lo., East Pitts-
Port Chenter Bolt \& Nat Co., Port Chester, N. Y. S-23.

Potter Sohnston Co., Pawtucket. R. I. Turning machines, etc. O-17.

Powell, Wm. Co., The. Brass speclalties. S-9.

Power. Regulator Co. Thermostats. I- 1 .

Pratt \& Whitney, Hartiord, Ct. Lathes and machine tools. 0-16.

Machlne tools, standards and gauges, taps, dles, reamers and milling cutters. Complete plants furnished for manufacturing the component parts of guns, sewing machlnes and simliar articles on the interchangeable system.

Prentice Bros. Worcenter, Masn. Lathes and driliing maahlnes. Q-16. Largest line driiling machine in the world. Englne lathes 12 to 24-lnch gwing. Electrically and belt driven. Awards : Chlcago, Brussels and Paris.

Prentins Tool and Supply Co., New York, N. Y. Lathes. P-8.

Purity Stopper Co., New York. stopper machines. B-6.

Quinby, Wm. E., New Yorlx, N. Y. Screw pump, removing water from base of Gruson Turret.

Rand Drill Co., New Yorls, N. Y. Drilis, etc. Drilis, engines, etc. N-T.

Reeves Pulley Co., Columbus. Ind. Power transmission machinery. $P-13$.

Repogle Governor Worka, Akron, oblo. Water wheel governors. $15-4$.

Rheinstrom Brow, Cincinnati, 0 . Filters. C-4.

Rider Ericson Engine Co., New York City. Hot alr engines. K-

Rivett-Doek Co., Brighton. Boston, Mass. Threading tools. $\mathrm{R}-9$.

Robins Conreying Belt Co., 13 Park Row New York. N. Y. Convey: lag machlnery. Exbibits show two fuil size Robins Patent Belt Conveyors In operation, with Automatic Trip. per for unloading the belt at any point. B-3.

Rodney Hunt Machine Co., Orange, Mass. Water wheeis, iumes, etc. $\mathrm{C}-11$.

Roebling \& Sons, John A., Trenton, N. J. Cables, etc. $\mathrm{F}-13$.

Roger" \& Co., S., Bunalo, N. $Y$. Knife grinding machinery. Q-16.

Roger: \& Hemphil, Alired, N. $Y$. Boring and turning mills. P-8.

Rollins \& Co., Geo. D., Phila., Pa., In Power Plant. Machinery packlag.

Rose Valve Go.. Troy, N. Y. Packing valves. $S-6$. 
Rowe, A. C., New York City. Fire extlngulshers. $0-26$.

Rasseli, Bnrannll \& Wara bolt and nut Co., Port Chester, N. Y. Bolts and nuts. S-20.

sackett Sereen Co.. Chicago, 111. Screens, and coal dealers' supplles. D-1.

Schieren \& Co., New York, N. Y. Leather belting. $\mathrm{N}-15$.

Sehreiber, L., \& Sons Co., Cincinnati, 0 . Superstructure. $\mathrm{P}-8$.

Scott a Williams, Philadelphia. Pa. Knittlng machines. The original and largest bullders of rib knltting machlnery in this country. All klnds of machlnery in the art of clrcular knltting for underwear, bosiery, etc. F-9.

Shelby Steel Talse Co., Cleveland, Ohlo. Tublng. I-2.

Sherwood Meg. Co., Buffalo, N. $Y$. Injectors, etc. $S-8$.

Simplex Time Recorder Co., Gardner, Mass. - Time recorders, etc. B-16.

skinner Euglne Co.. Phil., Pa. Engine. In Power Plant.

smith Machine Co., Smithville, $N$. J. Wood worklng machinery. C-4.

Snow Steam Pump Works. Buffalo, N. Y. Pumps in Power Plant.

Sockanonnet School, Providence, R. I. Tools. S-5.

South Bend Pulloy Co., Sonth Bend, Ind. Wood and steel pulleys. N-11.

Standara Tool Co., Cleveland, Ohlo. Twist drills and reamers. Exclusive manufacturers of "standard" twist drills, reamers, taps, milling cutters, drill chucks, end milis, involute gear cutters, and twlst drill grluding machlues. S-19.

starrett Co., L. S.. Athol, Mass. Machlnists' tools. $\overrightarrow{\mathrm{P}}-13$.

sterling Lubricator Co., Power Plant. Oils.

Straight Line Engine Co., Syracuse, N. Y. Lingine. Power Plant. $\mathbf{H}-\mathbf{9}$.

strnthers, Wells \& Co.. Warren, Pa. Gas engine. Power Plant.

Taluer Pump Co., Bufialo, N. Y. Rotary pumps. I-4.

Taylor. Iron \& Steel Co., Highbridge, N. J. D-2.

Hadteld's manganese steel . . hard, tough, durable, cannot be machlned, but does not break. Best material for wearlng parts of all kinds of machlnery for crushing and handilng ore, stcne, coai, coke, etc. Toerring a Co., C. J., Philadel
phla, Pa. Lamps in buliding. Tremont Mfg. Co., Roxbriry, Mau, yop for
Pipe tools. S-9.

Triamph Electric Co., Clncianath Ohio. Motor. F-7. tools and Underfeed Stoker Co., of America
Stokers. $\mathbf{M}-6$.

Vincent Valye Co., Orrosso, Hleh, Valves. $\mathbf{S}-\mathbf{5}$.

Vorhees Rubber Mfg. Co., Jenter City. Rubber mats. P-26.

Vulean Iron Works, Chicago, ill Plie driver. $\mathrm{H}-4$.

Walworth Mis. Co., Bonton, Man, Valves, etc. $\mathrm{M}-21$.

Warner \& Swasey, Cleveland ohio. Tools. Q-11.

Wnrren-omey Co., The, Gormer, Mich. Portable fire escape. P-46.

Wanhbern Shops, Worcett ctty. Mass. P-19.

Machinlsts, pattern makers, brass and Iron founders. Manufacturers of tine machlne tools and grinding machlaers. including the celebrated Worcester Drill Grinders. Send for catalogue,

Wntertown Engine Co., Watep. town, N. Y. Engine. In Power Plast $J-10$.

Weber Gas nnd Gasollne Engint Co., Kansas City, Mo. Englnes. $R-8$.

Wenzell Machine Co., S. S., Phlla delphia, Pa. Bottle machines. $0-5$. Veblcles.

Werner \& Pflelierer, Saginam, Mich. I. Notz, Mgr. Q-23. "Universal" Kneading and Mising Bu Machlnes; over 8,000 used by the chemleal and bakers' trades in this country and throughout Europe. How factory in Cannstatt (Germany).

Western Tube Co., Kewance, ill. Steel tublng, etc. G-2.

Westinghouse Co., Pittsburg, $\mathrm{P}_{\mathrm{a}}$ Generator. In Power Plant.

Wheeling Monld e Fonndry $\mathrm{Co}_{n}$ Wheellng, W. Va. Glass tumbler chlnes. N-4.

Wheeler Condensing and Engineering Co., New York, N. Y. Con. denser. In Power Plant.

white co.. L. \& I. J., Buffalo, $x$. Y. Edge tools, etc. S-22.

Whitney Mfa. Co., Hartford, Conn. Miling machines, etc. Q-17.

Wilmarth \& Morman Co.. Grand Raplds, Mlch. Drill grinders. H-17. 
Philladel. milliams \& Co.. J. H., Brooklyn, x. Y. Drop forgings. $Q-4$.

Vulcan chain plpe wrenches, special drop forgings. drop-forged wrenches, tools and machine parts.

Tood, Willinm T. \& Co., Arlington, Wass. Ice tools. G-21.

Worthington, Henry R., New York, N. Y. Steam pumping machlnery, condensers, etc. $1-6$.

\section{TRANSPORTATION.}

dmerican Fog Horn Co, Fog horn, $4-7$.

dmerican Ice Co., Philadelphia, Pa. Ice tools and wagon. H-23.

Imerican Motor Co., Newr York City. Gasoline launch. B-6.

Imerican Roller Benring Co., Boston, Mass. Roller bearings. F-15. Iutomobile Co. of Americn, New York City. Automoblles, $\mathbf{B}-6$.

Arres Son, Wm., Philadelphin, Pa. Horse blankets. H-22.

Bafley ot Co., S. R., Ameshury, Wass. Road wagons. B-23.

Baker Motor Vehicle Co., Cleveland, 0 . Automoblles. 18-E.

Bennett, J. C. S., Photo Enlargements, $A-18$.

Bryden Horse Shoe Co., Catasauga, Pa. Horseshoes. R-23.

Bnfalo Electric Carringe Co., Buffalo, N. Y. Automobiles. B-18.

Buffalo Gasoline Motor Co., Buftalo, N. Y. Motors.

Bufnlo Metul Goods Co., Buffalo, N. Y. Blcycle fittlngs.

Buffalo Spring \& Gear Co., Buffalo, N. Y. Vebicles in white. F-23.

Canadian Pactfe Rallway System, Montreal, Canada. Vlews. $\triangle-17$.

Cntely \& Ettiling, Cortiand, N. $Y$. Carrlage tops. E-26.

Chase, L. C. \& Co., Boston, Mass. Horse blankets, robes, etc. F-20.

Chicngo North Western $R$. $R$. Model ticlret office. $\mathbf{M}-25$.

Cleveland Ball and Screw Co. Cleveland, 0 . Steel balls. $\mathrm{F}-17$.

Conrad Motor Carriage Co., Buffalo, N. Y. Automoblles. F-7.

Consolfdated Hoof Pad Co.. New York Clty. Rubber hoof pads. H-20. Cowies \& Co., C., New Haven, Conn. Carriage trimmings.
Crane \& Breed, Cincinnati, Ohto. D-6.

Hearses. Manufacturers of metalllc burial cases and caskets, wood coftins and caskets, cloth-covered caskets, hardware and undertakers' supplies. Hearses, undertaklng wagons, hearse trimmings, etc.

De Dion-Bouton Motorette Co.. Brooklyn, N. Y. Automoblles. $16-$ E.

Durand Boat Mrg. Co., Rochenter, N. Y. Foot-power launches. $A-7$.

Eastman Antomobile Co., Cleveland, Ohlo. Automoblles. F-17.

Electric Vehicle Co., New York City. Automoblles. C-12.

Elkhart Corringe Co., Elkhart, Ind. Vehlcles. E-22.

Emery Tire Co., Providence, $\mathbf{n}$. I. Rubber tires. F-19.

Emplre Motor Works, Bufnalo, N. Y. Motors and gears. F-18.

Exceisior Machine Co., Buffalo, N. Y. Steel balls. $F-17$.

Fiak Rubler Co.. Bufialo, N. $Y$. Rubber tlres. E-26.

Gam Lngine \& Power Co.. nni Chas. L. Seabury \& Co., consolldated, Morris Helghts, on the Harlem, and 11 Broadway, New York, N. Y. A-4. The only naphtha launch, steam and sall yachts, marlne englnes, water-tube boilers.

Goodwin Car Co., New York, $N$. Y. Dumplng car. F-4.

Goodyenr Rnbber Co. Rubber tires. G-22.

Grnnd Trunk Railway Syatem, Montreal, Can. Vlews. A-0.

Grant Bail Mfg. Co., Cleveland, Ohio. Steel balls. F-17.

Grant Shaft Coupling Co., Pliladelphia, Pa. Coupllngs and horse. shoes. $\mathrm{H}-22$.

Grout Bros., Orange, Mass. Stenm vehicles. D-8.

Hallannn, M., New York, N. $Y$. Horse shoes and pads. F-22.

Hamburs American une, New York, N. Y. Models, maps, etc. C-3.

Haynes Apperson Co., Kokomo, Ind. Gasollne automoblles. B-20.

Hengerer Co., The Wm., Buffilo, N. Y. Bicycles. B-26.

Holland Amertcan Line, New York, N. Y. Model liner. C-1.

Hooker \& Co., Henry, New Haven, Conn. Vehicles. B-24.

Internationnl Navigation Co., Phlladelphia, $\mathrm{Y}$. Model llner. L-25. 
Irwin Chas. P., Red Bank, N. J. Ice bost models. E-7.

Kidder Motor Vehicle Co, New Haren, Conn Steam vehlcles. D-9. Knox Antomoblle Co., Springfield, Mass. Gasollne rehicles. D20.

Koller Carrtage Co., Glen Rock, Pa. Vehlcies. C-22.

Locomobile Co, of America, New York City. Locomoblles. D-17.

Milwnakee Automoblle Co., Milwaukee, Wis. Automoblles. A-20.

Moblle Co, of America, Tarrytown on Hudson, N. Y. Moblles. C-18.

National Cycle Mrg. Co., Bay City, Aflch. Cycles. B-22.

Niagara River Navigation Co., Toronto, Ont. Vlews. A-24.

New York Motor Vehicle Co., 26 Broadway, N. Y. Motor veblcles. Ifakers steam vehicles, omnlbuses, trucks, dellvery wagons, carriages ; kerosene oll used for luel; no odor; no smoke; no steam showing. Absolute safety, self-feeding boller.

Notman \& Son., Wm. Photo Enlargements. $A-18$.

Overman Anto Co., New York City. Steam automoblles. A-21.

Palmer Bros., Minnus, Conn. Launches. B-3.

Penamylvania Iron Works, Philadelphla, $\mathrm{Pa}$. Gasollne engines. H-4.

Pennnyivania Rubber Co., Erie, Pa. Tires, etc. $\mathrm{N}-21$.

Plerce, G. N. \& Co., Bnfalo, N. . Bicycles. Sole manufacturers of PanAmerican special bicycles which combine berel gear, chsinless, cushion frame and hub coaster brake. See "A Study in vibration." A-23.

Rewoue Life Boat Co., Muskegon, Mich. Life boat. $\mathrm{G}-6$.

Revere Rubber Co., Boston, Mams. Rubber goods, tires, etc. F-21.

Richellea \& Ontario Narigation Co., Montreal, Canada. Vlews. $\Delta-3$.

Rider Boller Works, New York City. Automobile boller. A-5.

Riker Motor Vehiele Co, Ellizabethport, N. J. Automoblles. D-13. Ambulazce, mail and patrol wagons in Exposition service.

Rock Fall. Mfg. Co., sterling, 11 . Ambulances, undertaking wagons, etc. D-7.

Schubert Bros. Gear Co., Onelda, N. Y. Veblcle gears. E-26.
Selle Gear Co., Akron, Ohlo,
Wagon gears. C-26. simpoon Thow, I., New York, Boal
fittings. D-9. Standard Antl-Friction Equip.
ment Co., New York, N. Y ment Co., New York, N. Y. Ball bea:
Ings, etc. F-16. Steamoblle Co. of Amerlca, Xer
York City. Automobiles. A -19 .

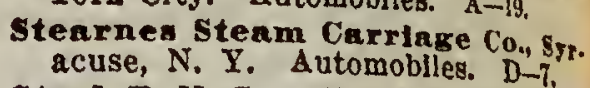

steel Ball Co., Chicago, III. Steel
balls. F-17.

Stratton Motor Cycle Co. Motor cycles. $D-24$.

studebaker Bros., South Bend, Ind. Vehicles. $\mathrm{H}-25$.

Thomns Motor Co., Bufinlo, $X_{1} Y_{\text {, }}$ Motor cycles, etc. $\mathrm{A}-21$.

Truscott Boat Co., st, Joseph, MIcb. Launches, boats, etc. $\Delta-5$.

Twentieth Century Mfy. $\mathrm{Cn}_{\mathrm{n}}$ Vehicle lamps. D-26.

U. S. Hame Co., Butralo, N, Y, Hames. G-21.

U. S. Tre Infiator Co,, Bufialo, $N$. Y. Tire Infators. C-24.

Van Wagenen, M., Syracuse, N. Y, Dump wagons.

Veeder Mfg. Co., Hartford, ct. Cyclometers, etc. F-18.

Wadman Cycle Co., Utica, N. Y, Bicycles. C-26.

Walburn Rlker, St. Paris, Ohio. Vehicfes. J-23.

Werner, Geo., Buffalo, N. Y. Car. rlages, buggles, etc. C-24.

west, Francts. Plotures, A-18, Wood Motor Vehtole'Co. Chlca. go, III. Automobiles. 15-B.

\section{MEXICO.}

Adminintracion General de Cor. reos, Mexico, Distrito Federal.

Postal conventions. Postal laws and regulations. Scales, Letter Boxes, etc.

Goblerno del Fmtado de Mexieo, Toluca. Sulvered and embroldered sad. die.

Leyartsh, Jose, Leon, Guanajuato. Saddes.

Lmon, Raimundo, Tulanclugo, uldalgo. Embroldered saddle.

Vent, Andres, Mexico, Distrito Federal. Mail coach model.

Vilcher, Tiburcio, Leon, Guanaju. ato. $A$ bit. 


\title{
Agrieultural Implements.
}

\author{
Thos. M. Moore, Supt.
}

The exhibits of agricultural implements are arranged under the south side of the Stadium Building.

\section{EXHIBITORS.}

dmerican Grask Twine Ca., Paul, Minn. Grass twine goods.

Blckford \& Hufman, Macedon, $N$. Y. Seed drllls.

Bowen Cable Stay Fence Co., Norwalk, 0 . Fence making machlne.

Bradley Mfg. Co., Bradley, III. Plows, cultivators, etc.

Bacher \& Giblos Plow Co., \& F. E. Ijyers \& Bro., Canton, O. Plows, etc. Buffalo Pltts Compnny, Bnfralo, N. Y. Agrlcultural machinery. In Misslon Bldg., north of Dalry Bldg.

Campbell Fanning Mill Co., Chatham, Ohio. Fanning mills.

Chadborn \& Coliwell Mfg. Co., Newburg, N. $Y$. Lawn mowers.

Coldwell Lavn Mower Co., Newburg, N. Y. Lawn mowers, etc.

Collins Plow Co., Quincy, I11. Plows, harrows, etc.

Deere \& Mansur Co., Mollne, III. Hay rakes, harrows, etc.

Deere a Co., Moline, III. Plowa and harrows.

Doty \& Derill, Los Angeles, Cal. Mower sharpener.

Dowden Mig. Co., Prairle City, Ia. Potato harvesters.

Emplre Drill Co., Shortsville, N. Y. Drllis.

Farquhar Co., A. B., York, Pa. Threshers, drllls, etc.

Frick Co., Waynesboro, Pa Tractlon englnes, threshers, etc. t. Genesce Valley Mig. Co., Mt. Morris, N. Y. Grain drills.

Hartman Mfg. Co., Ellwood City, Pa., Wire goods.

Hoover \& Prout, Avers, O. Pota. to digger.

Huntley Mfg. Co., Silver Creek, $N$. Y. Graln and seed machinery.

Iown Farming Tool Co., Fort Madison, lowa. Farming tools.

Kemp d Burpee Mrg. Co., Syracuse, N. Y. Manure spreaders.

Kemp Mfg. Co., Nevwark Valley, $N$. Y. Manure and fertillzer distributor.

Louden Mnchinery Co., FairfleId, Iowa. Hay carriers, door hangers, etc.

Mrast Co., P. P., Springfiela, Ohio. Grain drills and cultivators.

Myex d Brow.. F. E., Canton, 0 . Pumps, hay forks, etc.

oliver Chilled Plow Co, Sonth Bend, Ind. Plows.

Squier Mrg. Co., The Geo. L., Buffalo, N. Y. Plantation machinery.

studebaker Bros. Mrg. Co., South Bend, Ind. Farm and heavy wagons.

Supplee Hardware Co., Philadelphla, $\mathbf{P a}$. Lawn mowers.

Syracuae Chilled Plow Co.. Syracuse, N. Y. Plows, harrows, etc.

Wiara Plow Co., Batavia, N. $Y$. Plows, harrows, etc.

Withington \& Cooley Mrs. Co., Jackson, Mich. Farming tools, etc. 


\section{Railuay Exhibit Building.}

Thos. M. Moote, Supt.

\section{EXHIBITORS.}

Ameriean Rallway Supply Co., New York City. Badges, etc.

Baldwin Locomotive Works, Phlladelphia, Pa. Manufacturers of locomotives, single expansion and compound, compressed alr locomotives, electric locomotives and electric trucks, mine and tramway locomotives, etc.

Brill Co., J. G., Philadelphia, Pa. Bullders of electric rallway cars and electric and steam railway trucks; awarded Grand Prix, Paris Exposition of 1900 .

Brooks Loeomotive Works, Dunkirk, N. Y. Locomotives.

Buckeye Malleable Iroy and Coupler Co., Columbus, O. Couplers, etc.

nurnham, Williams \& Co., Phinadelphia, $\mathbf{P a}$. Electric engines, etc.

Consolidated Car IYeating Co., AIbany, N. Y. Car system.

Continuons Rail Joint Company of America. Continuous rall joints, step joints and insulated jolnts. Ten thousand $(10,000)$ miles of rall road track in the United States are equipped with continuous rall jolnts. General offices, Newark, N. J., U. S. A.

Delaware, Lneknwanna \& Western R. R. Co. Train and exhibit cars. Car fixtures, etc.

Edwards, 0 . M., Syracuse, N. $X$. Car fixtures, etc.

Gold Car Heating Co., New York City. Car systems.

Goodwin Car Co., New York City. Dump cars.

Goula Coupler Co., Deperv, N. Y. Couplers, etc.

right Inspection Car Co., Hagerstown, Ind. Inspection cars.

MeGaire Mrg. Co., Chiengo, In. Snow plow, sweeper, etc.

Merehants' Despatch and Transportation Co., New York City. ReIrigerator car. Meritt Eleetric Air Brake con
New York City. Air Lrakes,

Mornn Flexible Joint Co., Loals. ville, Ky. Rail joints.

New York Central Raliway, $D_{e}$ Witt Cilnton Train, locomotives, eich

New York Air Mrake Co, Broadway, New York. Works at $\pi_{8}$ tertown, N. Y. Alr brake equlpment. Makers of the famous Qulek Aetlon Automatic and Straight Air Braber Air Pumps, Eames Vacuum Brakes, and Automatic Vacuum Brakes.

New York Car Wheel Works, Bn. falo, N. Y. Car wheels and castlogs Chilled wheels and castings of all kinds for steam railroads, electric tram way and other service. Works at Buffalo, Ramapo, Boston, Hamiltor, Ont., St. Thomas, Ont.

Pedriel: \& Ayer Co., Phila., $\mathrm{P}_{\mathrm{a}}$ Air compressors.

Pressed Steel Car Co. Pittsbrig Pa. Steel cars, etc.

Riehmond Locomotive Works, Richmond, Va. Locomotives, etc.

Safety Car Henting and Lighting Co., The, New York, N. Y. The Pintsch system of raliroad car and buoy lighting. Adopted by most all the princlpal rallroads and resom. mended by the U. S. Government for buoy and beacon lighting. Direet steam, and hot water circulating heating systems for rallroad cars.

Schenectady Locomotive Workn, Schenectady, N. Y. Locomotives.

Simplex Railway Appliance $\mathrm{Co}$ Hammond, Ind. Trucks and bolsters.

Standaral Railway Signal Con Troy, N. Y. Signal system.

Standard Steel Worka, Philadelphla, Pa. Car wheels.

The Bueyras Co., Milwanke, Wis. Steam shovel. (East end of buliding, north of turntable.)

Sterlingworth Railway Supply Co., Easton, Pa. Steel freight cars. sroca Bango Ben gingl bag glue

bar

grali: $\mathrm{Bu}$ If

Ag

Cars 
ᄃ. S. Iail Car, in operation. Furaishing Exposition service.

reber Hailway Joint Co., New lork City. Rail Joints.

restinghonse Mfg. Co., D. Pittsburg, $P \&$. Air brakes, etc.

EXHIBITORS IN D., L. \& W. CAR BOX.

droca Wheel Co., Arocn, N. $\mathbf{Y}$. Bangor Slate Co., Hangor, Pa. ben Har Match Co. Matches. binghamton Overall Co., Bingbamton, N. Y, Overails.

nive Hiuge Packing Co., Wilkesbarre, $\mathrm{Pa}$.

Brake Dairy Co., PortInnd, $N$. $\mathbf{Y}$. Buffalo Pitts Co., Bufralo, $N$. $Y$. Agricultural machinery.

Carmel Connty Organ Co. Organs.

childs Fire Extinguisher Co. New York. Fire extinguishers.

Commercial Envelope Co., Bingbamton, N. Y.

Cotton Co., Earlville, N. Y. Perfumes.

Diamond Dairy Co.

Dr. Kilmer Srramp Koot, Binghamton, N. Y. Mediciues.

Egan, James. Mining Arilks.

Fantx Filtering Co., Lisherskin, N. Y. Filter.

Foster Dros., Cutlery Co.

Genesee Valley Mfg. Co., Monnt Morris, N. Y.

Gould Improved M. C. D.

Heintz Co. Canned goods, pickles, etc.

Howells Mining Drill Co., PIymouth, N. Y.

Hyatt Slate Co., Bungor, Pa. Slates.

Indian Spring Water Co.
Jackson Mfe. Co. Churaj.

Lestershire noot and shoe Mig. Co. Boots and shoes.

Mount Morris Milling Co.. Monnt Morris, N. Y.

Nazrreth Cement Co., Nazareth, Pa. Cement.

New Jersey Zinc Co., Newark, $N$. J.

Ola Homestead Co., Monnt IIorrik, N. $Y$.

Orego Bridge Co., Owego, N. Y.

Page's Seed Co., Green, N. Y.

Portland SInte Co. Slater.

Portlana Ccment Co., Wayland, N. $Y$.

Reese Machine and Tool TVorkw, S. Plymouth, Pa. Tools, etc.

Seranton Bolt und Nut Co, Scranton, $\mathrm{Pa}$.

Scranton Paint Co., Serantom, $N$. Y.

Shickshinny Worsted Mils. Worsteds.

Shepard, E. T., Oneida, N. Y. Window sash lock.

Sherwood Mfg. Co., Buffulo, $N$. $X$. Injectors.

Smith \& Co., E. H. Compressed alr sprayers.

Smith Premier Typewriter Co., Syracuse, N. Y.

Syrucuse Chilled Plow Co., Syracuse, N. Y.

The Rex Acetylene Generator.

Utien Kniting Co., Utien, $N$. $Y$.

Washington Silk Mills. silks.

Wniontha Kniting Co., Rushela Springs, N. Y.

White Packing Co., Monnt Morria, N. Y.

Whituey Eckstein Seed Co., Buffalo, N. Y.

Winters \& Prophet Canning Co., Mount Morris, N. $\mathbf{Y}$.

Wyoming Shovel Works, Wyoming, Pa. Shovels, etc. 


\section{Electricity Building.}

George Franois Sever, Supt.

\section{KEY TO INBTALLATION.}

For the purpose of conveniently locating the exhibits, the ground floor plan of the building (see opposite page) is divided into sections, which are indicated or the letters $A$ to $\mathrm{F}$ in one direction, and by the figures 1 to 23 in the other. Bi this system each exhibit has a position of longitude and latitude. For exmple, an exhibit indicated in the catalogue as being at " $F-4$," would be found at that point where a line drawn vertically from " 4 " intersects with a line drawn horizontally from "F."

Some of the exhibits named in the following list are shown in other places than the Electricity Building.

\section{NATURE OF EXHIBITS.}

Dynamos, Motors and other Electrical Machinery. Transformers, Lighting Apparatus, Electric Lights, Batteries, Conduits, Wire, Cables, etc. Apparatus for Electrical Measurements, Electro-Metallurgy, Telegraph, Telephones, Electro-Medical, Surgical and Dental Apparatus.

\section{EXHIBITORS.}

American Clock Co., The, 385 Wabash Are., Chicago. lilectric time systems. $20-\mathrm{F}$.

American Elec, Tele. Ca., $50 \mathrm{w}$. Jackson Boul., Chicago, 1i. Telephones. 17 -C.

American Engine 'Co., Bound Brook, N.J. Dynamos. Machinery Court.

American Steel \& Wire Co., New York, N. Y. Wire and cables. Machinery Building.

Anerican Tool Works Co., Cincinuati, Ohio. Electric motor. Machinery Building. American Watchman's Time Detector Co., The, 234 Broadway, N. Y. 3-E.

American Vitrifed Condult Co., 11 Cortlandt St., New York, N. Y. Conduits. 17-A.
Arnola Electric Power station Co., 1540 Marquette Blag., Chlcago, III. Electrical machinery. 3-F. Designers and bullders of complete electrical installations. Main office Marquette Bldg., Chlcago. New York office, Transit Bidg.

Bell Telephone Co., Bufialo. N. $Y_{*}$ Telephone exchange. $20-D$.

Bernard, E. G. Co." The, 460 Falton St., Troy, N. Y. Exbibit located in special building on lake shore, and operates Electric Fountain. Manufacturers dynamos, motors, electrical instruments, telephones, switchboards, and general electrical supplies.

Bettini Plionograph Company, 110 Flfth Ave., New York, N. Y. Phono. graphs. $16-\mathrm{F}$. 
Boymert Electric Const. Co., Utica, N. Y. Switches and panel boards. 15-i.

Buckeye Electric Co., The, Cleveiand, Ohio. Lamps. 12-C.

incandescent lamps.

Incandescent lamps.

Incandescent lamps.

Incandescent lamus.

Bullock Electric Mfg. Co., Cincinnati, Ohio. Dynamos, motors, etc. 9-C.

Camp, Ix. B. Co., 30t Park St., Akron, Ohlo. Conduits. 15-A.

Chase-Shawmut Co, Boston, Mass, Dutlet boxes. 6-F.

Clark Anto. Tele. Switchboara Co., Providence, R. I. Telephone apparatus. 22-C.

Consolldated Railway Elcetric Light and Equipment Co., 100 Broadway, New York, N. Y. Railway Exhibits Building.

Crocker-Wheeler Company, Annpere, N. J. Dynamos, motors, etc. Also in Gruson Turret. $10-\mathrm{F}$. Manufacturers and electrical englneers; general office and works, Ampere, New Jersey. Branch offices in all the large cities.

Catler-Hammer Mannfacturings Co., Milwaukee, Wis. Rheostats. 4-E.

Delany, Patrick B., Orange, N. J. Telegraph instruments. 14-F.

D'olier Engineering Company, 125 S. 11th St., Phliadeiphia, Pa. Dynamos, motors, etc. Machinery Bidg.

Dicke Tool Co., Downer's Grove, Iil. Electric ilnemen's toois. 14-A.

D. \&. W. Fuse Company, Proridence, R. I. Fuses. 23-E.

Edison Manufacturing Co., Fretory, Orange, N. J. Edison Laboratory products. $7-\mathrm{C}$.

New York oflce 135 th Ave. Chlcago offlce, 144 Wabash Ave. Foreign department, 15 Cedar St., New York.

Elec. Storage Battery Co., Philadelphia, Pa. Storage batteries. 7-E. Manufacturers of the "Chioride Accumulator" for troliey regulation, lighting and power stations, electric vehicles, launches, telephone, teiegraph, etc., etc.

Enreka Tempered Copper Works, North Fast, Pa. Copper speciaities, etc. $14-\mathrm{E}$.

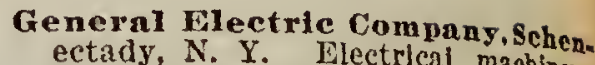
$5-B$.

Gonld Storage Hattery Company Depew, N. Y. Storage batteries.

HaIl, A. W., 32 Wells St, Bufraio, N. Y. Electrical advertising ma.
chines. $15-\mathrm{F}$.

Hanfeld, B. \& E., 107 E, 23d St, New York, N. Y. Medical apparatus. 23-C.

Hazard Mfg. Co., Wilkesbarre, Pa. Wires and cables. 16-C.

Holophane Glass Co., 15 E. 32d st, Globes, etc. 8-E.

Manufacturers of compound and sim. pie prism giass globes, shades and re. flectors for scientifically lncreasing the illuminating of all artificial lights: awarded two gold medals Paris, 1900 .

Hutchison, M. R., New York, N. Y. The Akouphone. 13-B.

Iluminating Appliance Co., New York, N. Y. $9-1$.

Inc. Elec. Lt. Manipulator Co, 110 Bedford St., Boston, Mass. Electric light manipulators. $23-\mathrm{B}$.

Jandas Flectric Company Cleveland, Ohio. Lamps. 12-C. Arc lamps, fan motors.

Arc lamps, fan motors.

Arc lamps, fan motors.

Arc lamps, fan motors.

Jantz \& Seitz, Cincinnati, Ohio. Hlectro. plating dynamo and driving motos, Graphlc Arts Workshop. .

Jolnnon, Fldridge R., Philadelphia, Pa. Gramaphones. 17-F.

Kelloge Switchboaril \& Supply Co., Chicago, 1il. Telephones. 18-E. $14-B$.

Keystone Electric Company, Erie, Pa. Electric machinery, working exhibit in Macbinery and Transporta. tion Bldg.

Lea Mauufactuxing Co, Elwood, Indiana. Arc and search lights 15-1.

Lincoln, P. M., Niagara Falls, N. $Y_{\text {, }}$ Phase indicator. $11-\mathrm{C}$.

Lubin, S., Philadelphia, Pa. 10-E. Life motion picture machines.

Mann Bros., 6 Wabash Ave., Chicago, Ill. Washing machlues. G-F. 
hen. Houn Monogram Company, 11 Brodway, New York, N. Y. Electrlc sgess. $21-F$.

chitar Publishing Co.. New Sork, N. Y. Publications. 20-A.

teRoy Clay Works, Brazil, Ind. Conduils, $16-\mathrm{B}$.

Yeprowltz, E. B., New York, N. Y. Eyo mgguet. Mfanufactures Bldg.

Yooris Electric Company, 15 Cortlandt St., New York, N. Y. Elecric suppiies. 12-A.

yrgatt, Otis A., New York, N. Y. t-D.

Tatlonal Antomatic Telephone Co., 75 W. Jackson Boul., Chicago, IIl. Telephones. 21-C.

vanufacturers of the National Automatic Telephones and party line phones; also serles nud bridging bells phoues. See our exhlbit.

ratlonal Carbon Company, Cleveland, Ohio. Carbons. 16-A.

ratlonal Gramaphone Corpornthon, 874 Broadway, New York, N. Y. Gramaphones. $18-\mathrm{F}$.

7lagara Falls Power Co., Ningara Falls, N. Y. Models of power plant. 2-D.

Sorthern Electric MfE. Co., MadiBon, Wis. Electric machinery. 5-E. onondnga Dynamo company, Syracuse, $N$. Y. Electrical machlnery. In Jachlnery Building.

Perkins, Frank C., Buffalo. N. Y. Electrical specialtles, 23-E.

Pern Electric Mfg. Co., Peru, Indiana. Porcelaln speciaities. $18-\mathbf{A}$.

Pittsburg Reduction Co., Niagara Falls, N. Y. Aluninum conductors. Manufactures Building.

Porter Battery Co., 1023 Monadnock Block, Chicago, III. Storage batteries, $14-\mathrm{E}$.

Richmondt Elec. Conduit Co., Milwaulee, Wis. Conduits. 6-F.

Robbins \& Myers Co.. The, Springfield, Ohlo. Motors, dynamos, fans. $17-\mathrm{E}$.

Roebling's Sons Co., J. A., Trenton, N. J. Wire and cables. Machinery Bldg.

Rowell, C. B., M. D., 945 Ningarn St., Buffalo, N. Y. Eíectro-static machlnes. 22- $\mathrm{F}$.

Safety Insnlated Wire and Cnble Co., New York, N. Y. Manufacturers of "Safety" Seamiess Rubber Insuiated Wire and Cabies for aerlal, underground and submarine use. Safety wlre used exclusively by the PanAmerican Exposition Co, 18-E.
Shedd Elec. \& Mfg. Co., New York, N. Y. Electric fans. Manufactures Bldg.

Spragne wlectric Co., 527 West 3 th St., New York, N. Y. Motor. LDiary Building.

Standard Paint Co., Now Tork, N. Y. Insulating compounds. Near Dairy Bldg.

Standard Undergronnd Cable Co., Plttsburg, Pa. Wlres and cables. 16-C.

Stanley Electric Mfg. Co.. Pittsfleld, Mass. Electrlc machlnery. 5-E.

Stanley Instrument Co., Great Barrington, Mass. Electrical Instruments. 6-E.

Stromberg-Carlaon Tele. Mfg. Co., 82 W. Jackson Boul., Chlcago, IIl. Telephones. Working exhibit about grounds. 18-C.

Submerged Electric Motor Co., Menominee, Wis. Electrlc launch motors. Electric boat propellors. It is the latest invention. Is in operation on the Park Lake. A portable and perfect outfit for small boats for pleasure and sportsman's use. $5-1$.

Syrncuse Electric Instrument Co., Syracuse, N. Y. Instruments. WorkIng exhibit in Machinery Bldg.

Toerring, C. J. Co., Are Lamps, 1035 Rídge Ave., Philadelphia, Pa. Exhiblt in Machinery and Transportation Bullding.

Wngner Electric Mfg. Co., St. Louls, Mo. Electricai machlnery. 10-B.

Wagner, R. V., \& Co., 308 Dearborn St., Chicago, IIl. Electro static machines. 23-C.

Waite \& Bartlett Mfo. Co., 108 E. 23d St, New York, N. Y. Electrostatic machlnes. 23 -D.

Warren Electric Mfg. Co., Sandusky. Ohio. Dynamos, motors and transformers. 18-C.

Western Electric Co., New Tork, N. Y. Telephones. 20-D.

Weatern Electrician, Chicaso, I1. Publications. 15-B.

Westinghonse Hectric and Mfg. Co., Pittsburg, Pa. Electrical machlnery. 11-C

White, O. C. Co., Worcester. Mass. Electric fixtures. $21-A$.

Wilhelm Telephone Mfg. Co., Bufalo, N.Y. Teiephones. 10-C. 
COLLECTIVE ELECTRIC EXHIBITS.

\section{W. J. Marland, Curator, 132 Nassau Stroet, Now York, N. Y.}

Bogne, Chas. J., 215 Centre St., New York, N. Y. Search lights. 3-F. Brown, Harold P., 120 Liberty St., New York, N. Y. Rall bonds. 3-F. Cameron, 11. P., Mec. Mrg. Co., 220 N. Clinton St., Syracuse, N. Y. Commutators. 3-F.

Chicngo Fume wire d Mre. Co., Chicago, Ill. Fine wires. 3-F.

Crescent irf. Co., 134 E. Tan Buren St., Chicago, ill. Cord adjusters. 3-F.

Cushing, H. G., Jr., 38 Cortlandt St., New York, N. Y. Wlring manual. 3-F.

Dlamond Are Lamp Co., 146 Mt. Vernon Ave., Mt. Vernon, N. Y. Arc lamps. $3-F$.

Dunn-Martin Elec. Co., 75 Nassau St., New York, N. Y. Medical batterles. 3-F.

Gdison-Johnson Elec. Mig. Co., 50 Broadway, New York, N. Y. Trolley harps. 3-F.

Electric Contract Company, 61 Iilm St., New York, N. Y. Testing sets. 3-F.

Ericsson Telephone Company, 296 Broadway, New York, N. Y. Telephones. 3-F.

Eschwei Electric Co., New York,

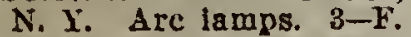

Gllbert, P. H., Scranton, Fa. Trolley pole. $3-F$.

Hart Mfg. Co., Hartord, Conn. Switches. 3-F.

Hazazer Telephone Co., 6 Dover St., New York, N. Y. Telephones. 8-F.

Berzog Telegeme Co., 81 Wert 24th St., New York, N. Y. Annuuciators. 3-F.

Hydra Double Battery Co., 32 Broadway. Batterles, 3-F.
Indelectrics Mig. Co., New Iork
N. Y. Medlcal battertes.

Krantz, H., Boerum P1. and state St., Brooklyn. Switchboards. $3-\bar{s}$

McLeod, Ward \& Co., 2y Thames St. New York, N. Y. Disk shades, 3-K,

Parsell \& Weed, 131 West 31 it St., New York, N. Y. Small motor and electric appllances. $3-F$.

Phelps Co., The, Detroit, Mich. Incas. descent lamps. 3-F.

Prentiss Clock Improvement $\mathrm{CO}_{4}, 48$ Dey St., New York, N. Y. Electric clock and time switches. 3-F,

Pyle Nat. Elec. Headifght $\mathrm{Co}_{0}, \mathrm{Chl}_{\text {. }}$ cago, III. Electric headlight. 8-F.

Queen \& Co., 1010 Chestnut st, Phlladelphla, Pa. Electrlcal measur. ing Instruments. $3-\mathrm{E}$.

Roche, William, 42 Vesey $\mathbf{S t}$, Ier York, N. Y. Dry batterles. 3-F.

Saze \& Bro., 130 Liberty St., Nen York, N. Y. Ohm meter. 3-F.

Socket Extension Tap Co., Boston, Mass. Extension taps. 3-F.

Speer Carbon Co., St, Marys, Pa, Carbons. 3-F.

Standard Flec. Welding $\mathrm{Co}_{\mathrm{n}}$ Cleveland, Ohlo. Electricaily welded materlals. 3-F.

Stewart, F. H, \& Co., 35 N. 7th stu Philadelphia, Pa. Cord adjusters. 3-F.

Stow Manufactaring Co, Bing. hamton, N. Y. Electrle motor and drill. $3-\mathrm{F}$.

'Inrdie, Emile J., 221 sixth Are, New York, N. Y. Electric nopelttes. 3-F.

Thomson Elec. Welding Con Lynn, Mass. Samples of electric welding. 3-F.

Utica Drop Forge Tool Co. 226 Broadway, New York, N. Y. Electilians' tools. 3-F.

Vosburg, W. G. Mfg. Co., 296 State St.. Brooklyn, N. Y. Electrlc fixtures. 3-F. 


\section{Mines Building.}

David T. Day, Supt.

\section{NATURE OF EXHIBITS.}

Ores, Iron, Copper and Nickel, Gold, Silver, etc. Limestones, Marble, Sandstones, Trap, Building and Ornamental Stones, Petroleum Products, Salts, Mineral Paints, Clay, Brick, Tile, etc.

\section{EXHIBITORS}

Abbott \& Embury Mine, Ontario. Hagnetlc lron.

teheson Graphit? Co., Niagarn. Falls. Graphlte and carblde of sllica.

Idama, J. W., Carmon City, Nev. Gypsum.

Adam, Miehael, Baltimore: Clay. Adelaide Mine, Contact, Giko County, Nev. Copper ores.

Alabama Kaolin Co., Boston, Mass. Clay and brick.

Alaska Marble Co., Portland, Ore. One column black marble.

Alagka Geographical Society, Sitka. Gold, copper and other ores.

Albany Stone Co., Albany, Oregon. Sandstone.

Albany Slip Clay Co., Albany, $\mathbf{N}$. Y. Sllp clay.

Neatrax Company, The, of Los Angeles, Cal. Refined asphalt.

Algonquin Red Slate Co., Worcester, Mass. Mlneral Palnt.

Alice A., Little Turtle, Mine Center, Ont. Gold ores.

Alida Valley, L. Chiatovich, Alida, Esmeralda Co., Nev. Lead and sllver.

Allen Granite Construction Co., Waterloo, N. J. Bullding stone.

Allen, Lem., st. Clair, Churchill Co., Nev, Tln ore.

Allen, W. H., Ottapra, Ont, Mica,
Allen d Willams, Midale Granvllle, N. Y. Slate.

Alta Mining Co., Gold Hill, Nev. Gold and silver.

Aluminum Lustre Co., Carwon City, Nev. Diatomaceous earth.

Amadone Mine, Nev. Silver.

American Asphalt Co., Lom Angeles, Cal.

American Coal Co., 1 Broadway, New York Clty. Coal.

American Copper Mining Co., Somervllle, New Jersey. Copper ores. Mlnes and mill on Watchlng Moun. taln near Somervlle, N. J. New York office, 20 Broad St. Joslah C. Relif, president; Joslah Bond, Gen. eral manager.

American Inst. of Mining Englneers, New York City. Publicatlons.

American Nickel Mining Co., Oregon.

Ames de., Carson City. Nev. Graphlte.

Ancram Iron Ore Co., Aneram, $\mathbf{N}$. Y. Iron ores.

Anderson, Angast, Ironwood, Mich. Iron ores.

Andes Mining Co., Virginia City, Gold and sllver.

Anglo-American Copper Co., Parry Sound, Ont. Copper ore.

April Fool Mine, De Lamar, Nev. Gold ores.

Arcadian Mine, Michiran, Ore and milled copper. 
Argentine. Collective Exhibit of ininerals.

Arizona Mine, Bullionville, Nev. Gold and sliver.

Ariagh nine, W. A. Payne, Mgr., Mine Center, Ont. Goid ores.

Armatrong, H. O., C. P. R. oflees, Montreal, Quebec. Sandstone, Desbarats, Ont.

Arnhyn Qunrey Co., Mehigan. Sandstone.

Arragon Mine, Norway, Mich. Ore samples.

Ashland Kaolin Co., Ashland. Oregon. Kaolin and dishes from same.

Aahand Stone Co., Aslinud, Oregon. Bullding stone.

Atkinson, J. H., Bath. Bullding stone, granite.

Atlantic Georges Creek Consolidation Coal Co., 114 E. Baltimore St., Baitlmore, Md. Coal.

Atlantic Mine, Michigan. Copper.

Atlas Arsenic Co., Ontario. Arsenic and arsenical ores.

Aura King Mine, Nev. Gald ore.

Aurora Mine, Alnmo, Lower Cal. care of H. M. Iussell, Los Angeles, Cal. Gold quartz.

Aurora Mine, M. T. Davis, Aurora, Mo. Zinc.

Anrora, Ner. Gold orew.

Babcock, $\boldsymbol{T}$. J., Wnterloo, N. $\boldsymbol{Y}$. Limestone and marbie.

Baden-Powell Mine, care of s. S. Forneri, Rat Fortage, Ont. Gold ores.

Bndger Mine, Nevada. Gold ore.

Baeder, Adammon \& Co., I'hiladelphia, Pa. Garnet.

Baer, H. L., Mancock, Meh. Copper.

Bailey, J. A., Breakneck. N. $\boldsymbol{Y}$. Granite and trap.

Bailey, J. E., Cold Sprine, N. $Y$. Granite and trap.

Bain, w. w., Carson City. Nev. Compressed wood, Comstock lode.

Baker Bros. \& Co., Newark, N. J.

Baid Monntain Co., Jackson Co., Oregon. Copper ore.

Baldwin Co., I., Waterbnry, Ma. Glass sand.

Baltimore Brick Co., 1001 Atintic Trust Bldg., Baitlmore, Md. Brick and tile.

Daltimore Retort \& Fire Brick Co., Hull \& Nichoison Sts., Baltimore, Md. Brick and tile.

Baltimore Mine, Nevada. Copper.
Bangs d Gaynor, Fayettevlile, $x_{\text {, }}$ rel $Y$. Cement rock and cement.

Hanga d Gaynor, Fayetteville, $x$, stinh Y. Gjpsum and land plaster.

Aanning. Hancock, Lon Angelea, profi,
Cal. Serpentine marble. Harber A phalt Paving Co. Bo falo and New York. Asphait But. Homarl other products.

Barclay, C., Carson City, Hackb Travertine, gypsum. Wles.

Barnet, II. S., Chentertowu, Md, plack Ciay and products.

Baxrick, S. N. \& Son, Woodubno, plack
Md. Limestone. Md. Limestone. Black

Barte11, Wm. E., Martinarille, d. plack
J. Bulding stone.

Barton, D. M., Troundale, ont \$ilve Mlca.

Barton Mining Co., Rarton, Ma, of Coal.

Marton \& Sons Co., H. H. Plila. deiphla, P'a. Garnet concentrates, massive garnet, and garnet paper.

Bates, A. D., Nevada. Sllver Sulphide ore.

Hay State hine Mining Con Zinc, Mo. Zinc.

BeniI, R. A., 14 S. Liberty st. Cumberiand, Má. Sandstone.

Benmarille Pressea Brick and Terra Cotta Co., Beamsville, Ont. Pressed brick and terra cotta.

Benver Dnm Marble Co., 71)4 Constitution St., Baltimore, Mid. Marble.

Behr, H., New York, N. $\mathbf{x}$. Garnet paper.

nelcher Mining Co., Gold Hill, Nev. Sliver ores.

Belding, Mrilo G., Gouverneur, N. Y. Marble.

Bell, L. C., Ione, Nye County, Ner, Phosphate rock.

Rell \& Court, silver Peak, Emme. ralda Co., Nev. Iron ore, sllver and gold ore.

Belmont Mine, Mormora \& Hel. mont, proprietors, Ontario, Canada. Gold ores.

Beltzer Mining Co., Nevala. Copper ores, lead ores.

Bennet, Eiw., Britimore. RoofIng, tlle works.

Bennett, Frank, Staten Island, N. Y. Trap.

Bernari, C. E., Carlin, Nev. In. fusorial earth.

Bernice District, Nevada. Silver ores. Big Master Mine, Upper Maniton Lake, Ontario. Gold ores. 
X. Tein Coul Co, 21 Sonth Gay is, Baltimore, Md. Coul.

pirkhine, John, Philadelphia. Publications of Frankifin Institute.

graey, David, German Valley, $N$. i.

Ialt and dumark Mine, Candelarla, Nev. Siliver ore.

Aeq, Hackburn Bros., ottarva, Ont. vica.

Md, Hack Donald Mine, Brougham Joprship, Ont., care of J. W. McRae, ottawa, Ont. Graphlte.

Black Hawk Gold Mining Co., Hat Portage, Ont. Gold ores.

glack Jnck Mine, Ploche, Nev. Sllter ore.

Black, J. F., Sudbury, Ont. Map of Ontario showing mines and mining centres, mineral collectlon.

glack Republic Mine, Roseburg, Ore. Copper ore.

Black, Sheridan \& Wilson Co., 1.3 Chamber of Commerce, Baitimore, IId. Coai.

Blatne Conl Co., Blaine, Went Va. Coal.

Blossom, J. A., Bnttle Monntain, Ner. Gold, sllver, iron and copper ores.

Bloe Blrd Mine, Nerada. Conper. Blue Jay Mine, Carson City, Nev. Copper.

Bine Ledge Mine, Jomephine Co., Oregon. Gold ore.

Blue IIt. Irou and Stcel Co., Catochin, Md.

Blue Stone Copper Co., I. Shaw, Yerington, Lyon Co., Nev. Copper ores.

Boerth Mne, Ardoch, ont. Gold ores.

Boice, Hewitt, Rondont, N. Y. Sandstone and blue stone.

Bonelli, D., Roville, yincoln Co., Nev. Asbestos, manganese.

Honelli, D., Rioville, Ner. Mica, rock sait, petrifled wood carrying gold.

booher of Alberti, Elko, Nev. Natural soap.

Boom, J. W., Syracuse, N. Y. Gold and sllver ore.

Boose Bros., Forent Grove, Ore. Buliding stone.

Borden Mine, Frostburg, Ma. Coal.

Boss Mine, Belleville, Ner. Lend ore.
Boston \& Nevada Copper Co., Yerington, Lyon Co., Nev. Copper.

Bouton, A. W., Roxbury, N. Y. Sandstone and blue stone.

Borvden Mine, Jackson Co., Oregon. Gold ore.

Bowman, J., Rossport, Ont. Copper and nickel ores, pyrrholite, etc.

Boyce, F., Carson City, Nev. Fonsil.

Brady, Gilbert, Rochester, N. $Y$. Flagstone.

Branil Mne, Yerington, Lyon Co., Nev. Copper.

Brazil. Collective Exhibit of ores.

Brindle Cnt Mine, Myrtle Creek, Oregon. Copper ore.

Bristol District, Ploche, Nev. Copper ores.

Brookfield Mining Co., Joplin, Mo.

Brooks, A. H., U. S. Genlogleal Survey, Washington. Gold and tin from Cape Nome.

Bronky, Peter, Frederick, Ma. Brick and tile.

Brnce Copper Mining Co., Ontario, Canada. Copper ores.

Brnnawiek Canon, Carson City, Ner. Crystals.

Brnah Bros., Jervetsville, $\mathbf{N}$. $Y$. Shale and brick.

Buena Vista Spring Water Co., Baitimore, Md. Mineral water.

Buffalo Cement Co., Buffalo, N. $Y$. Cement rock and cement.

Bullion District, IR. E. Skaggs, Elko, Nev. Lead and siliver ore.

Bullion Mine, Elko, Nev. Stlver ore.

Bullion No. 2 Mine, care of $D$. C. Cameron, Rat Portage, Ont. Gold ores.

Burean or Mines, Toronto. Ont. Dressed ornamental and buliding stones and the various economic ores of the Province of Ontario.

Burhand \& Brainard, Saugerties, N. Y. Sandstone and blue stone.

Burke, J., Steambont Springs, Ner. Cinnabar, gypsum, barium.

Burns, F. F., Whitehair, Mu. Flint and feldspar.

Burns Russell Co., s35 Columbia Ave., Baltimore, Mà. Brick and tile.

Burnolde Mine, Mantingw, Col., Ontarlo, Canada. Iron pyrites.

Button Mine, Golconda, Nev. Copper ores. 
Coirnw, Ralph, Walton, N.Y., Flagstone.

Caldwell, T. B., Lanark, Oni. Iron ore.

Caldrvell, W. C., Lanark, ont. Granite.

Callfornin, collective exhlbit of ores from the State Mining Bureau, San Francisco, Cal. A. L. Cooper, state mineralogist.

Calumet \& Contact Co., Contact, Elko Co., Nev. Copper ores.

Calumet \& Hecla Mine, Buffalo, N. Y. Copper.

Calmmet \& Hccla Mine, Michigan. Ore and copper.

Cameron Island IIfine, Cameron Island Mining Co., Toronto, Ont. Gold ores.

Campbell, Eugene, Mednsn, N. Y. Limestone and marble.

Canadn Corandum Co., B. A. C. Cralg, Toronto, Ont. Corundum.

Canadian Copper Co., Copper Cliff, Ont. Smelting and metallurglcal works, products. Samples from their several mines at Suabury in large blocks.

Canadian Gold Fields Co., Deloro, Ont. Arsenic and arsenical ores.

Manufacturers of pure white arsenlc (arsenic oxlde.) Prepared to fill all orders promptly. Only sold in kegs bearing (C. G.) brand.

Canadian Northern Rnllway. Iron ore from Atlkokan range west of Port Arthur, Ont.

Canadian Peat Fuel Co., Toronto, Ont. Peat fuel.

Canadian Portland Cement Co., Desoronto, Ont. Portland cement.

Capnel, Thomas, Lake Linden, Mich. Native copper.

Carpenter, A. V., Contact, Elko Co., Nev. Copper ores.

Carpenter, B. \& J., Lockport, N. $Y$. Limestone and marble.

Carpenter, Coles A., Sea Chif. Potter's clay and kaolln.

Carroll, Robt., Toronto, ont. Bullding and ornamental stones.

Camcades Mineral Spring Co., Portland, Ore. Mlneral water.

Cascadia M. Co., Oregon.

Catherine Lead Co., Madison Co., Mo.

Cayuga Plaster Co., Union Springs, $N$. $Y$. Gypsum and land plaster.

Cecil Fire Brick Co., North East, N. $x$.
Central Conl and Coke Co, Kan. sas City, Mo. Coal.

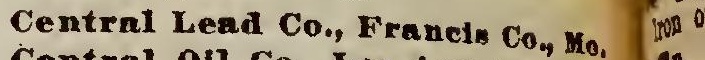

Central oll Co., Lon Angeles, Ho, Crude olls.

Chainman Mine, Ely, White Pine Co., Ner. Gold ores.

Chnllenge Mine, Grants Pann, ore dore Gold ore.

Champion Mining Co., Bencon (llas Mich. Ore samples.

Chapln Mrining Co., Iron Moun. tain, Mich. Ore samples.

Chattolnnee Springs Hotel and Water Co., Baltimore.

Chazy Marble Lime Co, Chary, 1. $Y$. Limestone and chemical lime.

Chiatovich, H., Silver Peak, Enmeralda Co., Nev. Gold and sllier ores.

Chlcago \& West Island stone co. Dressed stone from near Port Arthur, Ont.

Chlldx Photograph Gallery, Ihpeming, Mlch. Surface and underground vlews.

Chisholm, J. H., Cloyne P. O. Iron ore.

Choynorth, Ben., Houghton, Mich. Native ores.

Christian Co. Mines, Christinn Co." Mo. Lead and zlnc.

Churchill County, Nevada. Gold, silver, nickel and cobait, tin, antl. mony.

Cinabar Mine, Grants Pasn, Oregon. Cinabar.

Clark, J., Nevada. Gold ore.

Clark, S. W.. Willsboro Polnt, $\mathbb{N}_{\text {. }}$ Y. Limestone and marble.

Clarke mlue Stone Co., F. G, Ox: ford, N. Y. Sandstone and biue stone.

Clarkron, A., Potsdam, N. Y. Sandstone and blue stone.

Clarkson Bros., Fagerstown, Md. Limestone.

Clementine Mine, Nevada. Gold and sllver.

Cleveland Chifs Mining Co., lshpeming, Mich. Ore samples and photographs.

Cleveland Stone Co., The, Cleveland, Ohlo. Bullding stone.

Clinton Iron ore Co., Clinton, $x$. Y. Iron ores (red hematite).

Clinton Metalile Paint Co., Clin. ton, N. Y. Mineral palnt.

Cochrane, Frank, Sudbury, Ont. Gold ores. 
0, Kas, de, Ho, Perth, Ont. Mloa. Hill Mne, Ontario, Canada.

Co., Mo, ton ore, ind ore (carbonate).

teman, Dr. A. P., School of Practhel Sclence, stones from north mors, Lake Superior, Ont.

yllina, Geo. M., Crisfleld, Ma. clieg and products.

worado Academy of Nat. Scienins, Denver, Col. Publicatlons.

alorado of Wroming Investment ca, Cheyenne, Wyo. Copper and other ores.

colmbia Mine, Enther, st. Francols $\mathrm{Co}, \mathrm{Mr}$. Lead ores.

comet Mine, Nevada. Copper ores. commonwealth Mine, Tuscarora, Nier. Sllver ores (ruby).

comatock Lode, Nevada. Silver snd gold ores.

conochengae Briok Farthengare Co., Williamsport, Md. Brick and tile.

conpors, Whlliam, Troy, N. Y. Paint and mortar color.

Courad, c. E., Krallopell, Mont. Gold nuggets.

connolldated Virginia and Cal., Virginla City, Nev. Gold and sllver.

conolldated Wheatland planter Con, Wheatland, N. Y. Gypsum and land plester.

Consolldation Conl Co., 44 sonth Street, Baltimore, Ma.

Copper Canon, Nevada. Copper ores.

Copper King Mining Co., Jackmon Co., Ore. Copper ore.

Copper Queen Consolldated MinIng Co. N. Y. C. Copper.

Cortez Mine, Nevada. Silver ore. Cow Creek Mining Co., Douglam Co., Ore. Copper ore.

Cowan \& Znbriakie Mine, Carmon. Ner. Lead and sllver ores.

Cox, Col. J. N., Calnmet, Mich. Minerals.

Crencent Gold Mining Co., Malone, Ont.

Crlchton \& Petrie, Dyment, ont. Gold ores.

Ortm, A. B., Middueville, N. Y. Quartz crystals.

Crown Cornndum Co., J. Carrs, Toronto, Ont. Corundum.
Cumberland Hydranlle Cez. Co., Cumberland, Ma. Cement.

Cundy Mining Co., QuJneare, Mich. Ores and speclmens.

Curry, Lient. George, Ironpaod, Mlch. Iron ore.

Crarina Mine, Rloville, Nev. Lincoln Co., Nev. Mica.

Dake, C., Carmon City, Ner. Tripollne.

Daniel \& Leonara, Baltimore. Granlte.

Davies, A. R., North Litchfield, $N$. Y. Lime and cement.

Dari. Coal \& Coke Co., Pledmont, West Va. Coal.

Davin, Cyrns, Berlin, Md. Clay.

Drvin, R. J., Valley, Wash. Iron ore.

Davis, Wm., Marriottøville, Md. Limestone.

Day Mine, J. Grandelmyer, Hamliton, Nev. Sllver ores.

Deer Horn Mine, Gola Hill, Ore. Gold ore.

Deeth, Elko Connty, Nev. Phonphate of llme.

DeGraf \& Robertw, Fagle Farbor, N. X. Flagstone.

Delaware Mine, Virginin City, Nev. Infusorial earth.

Delaware Mining District, Carson, Nev. Copper ores.

Delaware Mining, Milling \& Manufacturlng Co., Roxbury, N. Y. Mineral paint.

Delono Mine, Ploche, Nev. Copper ore.

Delmonte Mine, Nevada. Copper ore.

Depuin, P., Carmon City, Nev. zine shaplngs.

Deneret Borax Co., White Plainw, Nev. Borax, ulexite, salt.

Deseronto Furnace Co., F. B. Gaylord, Deseronto, Ont. Smelting and metallurgical and products.

De Van Nostrand Co., N. Y. C. Publications.

Dewabie Minins Co., Iron Drountaln, Mich. Ore samples.

Diamond Mine, C. Reed, Eurelá, Nev. Lead ore.

Dibble, Alfred, Belvidere, N. $x$. Bullding stones 10-1nch cubes.

Dickey Gibson Coal Co., Pledmont, West Va. Coal.

Dittman, Wm. C., Texas, Ma. Limestone. 
Dixon Cruelble Co., Jersey City, N. J. Graphite and graphlte products. Dobson, Alex., Beavertox, ont. Peat fuel.

Doe Run Lead Co., Doe Run, Mo. Dooley, N. P., Ploche, Nev. Gold, silver, copper, lead ores.

Dorsey, v. W., Marriottaville, Ma. Llmestone.

Douglas Connty, Nevada. Gold, sllver, copper, ores.

Douglas, James, N. Y. C. Copper spec.

Drake Co., The, St. Paul, Minn. Petrifled wood.

Dufieli Mine, Jackson Co., Ore. Gold ore.

Dunkel, w. T. \& Co., Baltimore. Mineral paint.

Dunlap. E., Sodaville, Ner. Copper ores.

Dumn, L. F., Winncmucea, Nev. Silver ores, fossll.

Dunstan, J. H., Negaunee, Mich, Ores.

Dupuis, P., Carson City, Nev, Zinc shavings for cyande process of recovering gold.

Eagle Mine, Stillwater, Churchil Co., Ner. Gold ore.

Eagle Lake Mine, Eagle Lake Gold Mining Co., Rat Portage, Ont. Gold ores.

Eagle Salt Works, Reno, Nov. Salt. East Brownville, Mnine, Slate Co., Brownville, Me. Siate.

Eastern Oregon Knolin Co.. Portland, Ore. Kaolin and dishes from same.

Eastern Paring Brick Co., CatmkIIl, N. Y. Brick and shale.

Enston. Elaridge \& Co, Lon Angeles, Cal. Crude olls.

Eckert, H., Madoc, Ontario. Iron ores.

Edraras, Capt. Richard, Calumet, Mich. Ores.

EAwarin, Robert h., Houghton, Mich. Native copper and silver.

Effe Mine, Nevaia. Copper, gold and silver.

Eichner Bros, Cumlerland, Md. Pottery.

weetrie Mining and Reduction Co., Reno, Nev. Gold, sliver and lead ores.

Electro sulicon Co., Virglnia City, Nev. Infusorial earth.

Elgin Stone Co., Elgin, Ore. Bullalag stone.
Ellis, P. W., Toronto, Ont. Bulld. "njyllin Ing and ornamental stones. Euris \& Co., P. W., Toronto, Ont, salilin
Marbles. Elko Connty, Nevada. Copper, prereck
gold, silver, asbestos, etc.

El Salvador. Collection of oren merlek

Elwell-Danington Mining $C_{0}$ rederick

Seattle. Copper and gold. $\mathrm{CO}_{4}$ (mpman

Emmons, Ed. S., Lovelockx, Xer, frre \& Sulphur, Iron, silica.

Empire Cement Co, Warners, $x$, filton IIi Y. Marl, clay, cement cliniker and cement, surace

Empire Milling Co., Carson City, tio, Nev. Plaster paris, gypsum.

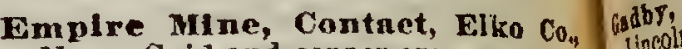
Ner. Gold and copper ore. Lipeolr

Emory, Dr., Toronto, Ontarlo, galena Iron pyrites, Thunder Bay District. Gaster,

Empress Mine, Ontario, Canada, cases. Gold ores.

Englineering and Mining Journal, N. Y. City. Publications.

Eugle, Horace M., Roannke, $V_{a}$, Asbestos.

English Plaster Works, Oakfeld, N. Y. Gypsum.

Eameralda Connty, Nevaila. Oren, Esperanza Mine, Pioche, Ner. Cop. per, gold and sliver ore.

Eureka County, Neradr, Lead and silver ores, molybdate, alnc.

Evans \& Howard, St. Louls Mo. Clay products.

Everson, Hans, Ironwood, Heh, Iron ore.

Excelsior Slate Co. (of Hartford Co.), Deita, Pa. Slate.

Exchequer Mine, Josephine $\mathrm{C}_{0}$ Ore. Gold ore.

rarr \& Bniley, Camien, Pa, ofl cloth painted with New York State paint.

Fay Mine, Mamilton, White Pine Co., Nev. Copper ore.

Fibert Paving and Construction Co., Baltimore. Bullding sand.

Fitch, A. B., Magdalena, New Ier. ico. Gold and sliver ores.

Fogelsonger, C. \& H., Bnfialo, $\mathrm{x}$. Y. Limestone and marbie.

Foley Mine, Shoal Lake, Mine Center, Ontario. Gold ores.

Folger Bros. J. Hammond, es. tate, Fort William, Ont. Copper ore.

Forsyth, R., Grindatone Isinnd, $x$. Y. Granlte and trap, 10-Inch cubes.

Franche, Capt. F., Godertch, ont. Iron ore. 
nt. Balld. vogkin Mine, Michigan. Ore 4. and milled copper.

to, Ont, antiln Refining Co., Los Angebal. Oll and mineral exbibit. Coppes, prederick Brick Works, The,

of ore, fiederick City Lime Co. Lta., $\mathrm{CO}_{4,}$ Trederick, Md. hreman, P., Sydenham, Ort. Mica.

Ner, frre \& Bros., O. O., Mining Co., Jopllin, Ilo.

futton iline, Nevada. Copper ore. propaceville Iron Ore Co., Ontatio, Wajne Co., N. Y. Iron ore (red bematite).

asdbr, Buntin \& Doyle, Dxceola,

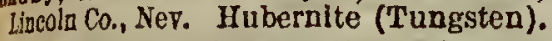
Galena 011 Co., Frankila, Pa. ianter, F., Baltimore, Md. Plato Glass cases.

Gardner Mine, Carson, Nev. Copper ore.

Genesee Salt Co., New York, N. Y. Salt. George, John, Joplln, Mo. Calcite specimen.

eld, Georges Creek Conl and Iron Co., 侻 Equitable Co., Baltimore, Md. Coal.

German, M. H., Delaware, Del. Clay and products.

Gertrude Mine, Lake Snperior Porer Co., Ont. Copper and nickel ores, pyrrhotite, etc.

Gibbs, F. N, Port Arthnr, Ont. Collection of Ontario silver ores.

Glbson, W., M. P., Beamsville, Ont. Limestone.

Gllbert, Brady, Rochester, N. Y. Flagstone.

Gllpin, John, Elkton, Md. Brick and tile.

Glancow \& Western Exploration Co., Goiconda, Ner. Copper ores.

Glen Morris Flint Mil Co., Glen Morris, Md. Filnt and feldspar.

Glens Falls Co., Glens Falls, $\mathbf{N}, \mathbf{Y}$. Llmestone and marble.

Glens Falls Portlnud Cement Co., Glens Falls, N. Y. Limestone, ciay, cement clinker and cement.

Golconda Mine, Josephine Co., Ore. Gold ore.

Gold Bng Mine, Josephine Co., ore. Gold ore.

Golden Crown Mine, Jackson Co., Ore. Gold ore.

Gold Ridge Mine, Myrtle Creek, ore. Gold ore.

Golden Star Mining Co., Ion. S. C. Wood, Pres., Toronto, Ont. Gold ores.
Gold Winner Mining Co., Dulath, Minn. Gold ores.

Goodwin, H. Price, Westminster, Md. Limestone, lime and cement.

Grahnm Mine, North Shore Lake Superior, Ont. Copper ore (native copper).

Granby Mining \& Smelting Co., Joplin, Mo.

Grand Hotel Co., Lta., Caledonia Springs. Mineral water.

Caledonla Springs-famous Canadian cure-rheumatism, stomach, liver and kidney troubles. Saline aperient, white sulphur, diuretic and table waters. Sold everswhere. Ask for clrcular.

Grand Prixe Mine, Tuscarorn, Nev. Ruby silver.

Granielmyer, J., Hamilton. White Pine Co., Nev. Silver àd lead ores.

Graves, F. F., Doe Ran, Mo.

Grent Lakes Conper Co., Sndbury, Ont. Copper and nickel ores, pyrrhotite, ete.

Grent Republic Gold Mine-Co., Seattle. Stibuite ore.

Greatris, W., Madoc, ont. Iron ore.

Green Hill Fire Brick Co.. North East, Md. Brick and tlle.

Greene, J. O. J., Westernport, Ma. Coal.

Grey Eagle Mine, Jackwon Co., Ore. Gold ore.

Grifln, J., Reno, Nev. Copper ore.

Grinnell, Exra, Port Glbson, N. $Y$. Gypsum and land plaster.

Grove Co., The M. J., Lime Kiln, Ma. Limestone, lime and cement.

Guntemala. Collective exinibit of ores, granite, kaolin; mica, etc.

Gailford and Walternville GranIte Co., 52 Central Savlngs Bank Bidg., Baitimore, Md. Granite, gypsum, plaster parls cast of Miss Canada. Ontarlo sectlon.

Haines, S. S., Union Bridge, Ma. Limestone.

Hamilton Corundam \& Emery Wheel Co., H. E. Sherk, Mgr., Hamllton, Ont." Corundum goods.

Hamilon Steel and Iron Co., Hamliton, Ont. Smeltlng and metallurg!cal works and products.

Hang, Matt, Foughton, Mfeb. Copper and sllver.

Hanke, M., Contact, Elko County, Nev. Copper ores.

Harrin Mine, Waghoe Citr, Nev, Gold ore. 
Harrion, J. J. L., Newburs, N. Y. Limestone and llme.

Harriwon, J. F., Madoc, Ont. Arsenlc and arsenlcal ores. Iron ore, talc, actlnollte.

Hattie Bell Copper Mine, Parry Sound, Ont. Copper ores.

Hawthorne District, Nevada. Gold ores.

Hayes Mining Co., Ironwood, Mlch. Iron ore.

Haynen, D. F. Son, Baltimore. Pottery.

Heditrom, E. L., Bufialo, N. $Y$. Conl.

Helaenbutte, G.' W., Rldgefleld, $N$. J. Bullalng stones.

Helen Mine, Michipicoton, Ont. Iron ore.

Henderson Mine, A. A. Robinw, New York, N. Y.

Henry Booth Mine, Merilu, Jonephlne Co., Ore. Gold and copper.

Herbert, I. S., North Granvilie, $N$. ¥. Slate.

Herderbers Cement Co., Hoven Cave, N. Y. Lime and cement.

Terrman \& Laxion, Dryaen, Ont. Gold ores.

Hewitt, D. C., Amateriam, N. $Y$. Limestone and marble.

Fibbard-Rodman-EIy Safe Co., $N$. Y. Clty. Safe.

Hibernia Mine, Hibernia, N. J. Iron ore.

Highiand Dintrict, N. P. Dooley, Ploche, Nev. Sllver, lead, ore.

Hillside Mine, $N$. $P$. Dooley, Ploche, Ner. Sllver, lead.

Filton, Waiter E., Dankirk, N. Y. Clay and brlck.

Holloway, Mrs. John, Medina, $N$. Y. Sandstone and blue stone.

Holmes Mining Co., Candelarin, Ner. Sllver ore.

Rome 011 Co., Whittier, Cal. Crude oll.

Home Stake Mine, Jackson Co., Ore. Gold ore.

Hondnrax. Collective Exhlbit of mlnerals.

Hood River Stone Co., Hood River. Ore.

Foran Bror., Medina, N. Y, Sandstone and blue stone.

Rorne Shoe Mine, Deerlodge Diwtrlct, Llncoln Co., Nev. Gold ore.

Horne Shoe Mine, Jackson Co., Ore. Gold ore.
Hotchkism, L. W., Lewiwton,
Sandstone and blue stone.

House \& Brown, Johnmon, $X, Y$.
Llme and llmestone.

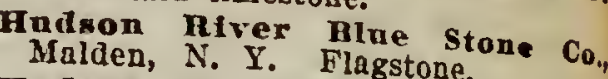

Halden, $Y$. Nagstone.

Burden, N. Y. Carbonate Iron Co.

Humboldt Connty, Nevade

sllver, lead, copper, sulphur, Gold, stone and marble.

Hungerford Marble Co., Toronto,
Ont. Bullding stone.

Hughes, J., Syracase, N. Y. Lime. stone and marble.

Hunter a Plxley, Nevada. Copper
ores, gold ores.

Ida Mine, Garfield, Ner. Silver Imperial Cement Co., Owen Sound,
Ont. Portland cement.

Imperial Cornndum Co., I. Mor. rlson, M. P., Toronto, Ont.

Imperial oil Co., Sarnia, Ont. Petroleum products.

Independence Mine, Nerada. Copper ore.

International Nickel Co, RIddien, Ore. Nickel ores.

Inyo Dev. Co., Carson, Nev. Soda carb., soda bl-carb., soda ash.

Ione, Nevaia. Silver and lead ores.

Iron Co., Mro. Ores.

Irridescent Mine, Nerada. Silver ore.

Isanagle, Geo. M., Catochin, Md. Limestone.

Ives, James T. B., N. Y. City. Geologlcal map.

Jacologille Brownatone $\mathrm{Co}_{\text {. }}$ Mlchlgan. Sandstone.

Jacob's Wonder Mine, Nevada, Gold ore.

Jamentown Shale Paving Brick Co., Jamestown, N. $\mathbf{Y}$. Shale and brick.

James, J., Actinolite, Ont. Iron pyrites.

Jellerson, N., Carson, Ner, Disa covery ore of Comstock lode.

Jewettwrille Pressea Brick Ca, Jewettsvlle, N. Y. Brlck.

Joanna Mine, S. Hilp, Reno, Nev. Gold ore.

Johna Hopkins Univeraity, Halti. more. Publications.

Johnw MPr. Co., H. W., N. Y. City. Asbestos. 
N. Y, Joson and Co., E. J., 35 Park don, New York City. Slate.

hnon, Vivinn, Houghtor, Mich. sutire copper with calcite.

oplis Clab, Joplin, Mo.

mine Mine, Michipicoton, Oatarlo, Canada. Iron ore.

what Broad, Negnanee, Mich. Otes.

nombo Distriet, G. Schisslex, CarNon Ner. Copper and sliver ore.

istice Mining Co., Gold Hill, Sier, Gold and sllver ores.

salb son, George S., Cintonsrllle, Mid. Pottery.

naminntiquia Sta., C. P. R. Iron prittes.

reller, E. D., Carmon, Nev. Stlver and lead ores.

kelly, Wm., Vulcan, Mich. Spec. Calcte, pyrite and quartz.

remp, J. F., Columbinn University, N. Y. City. Publication: "Ore Deposits."

Seres, Wayland, Rochenter Juncton, N. Y. Peat.

kice, Lyman, German Valley, N. J. Bullding stone.

Ring, A. Gracle, Garrimons, N. Y. Granite and trap.

Klakel, P. H., Bedford, N. $\mathbf{Y}$. Quartz and feldspar.

Rlein, J., Huwthorne, Nev. Gold ores.

Kreiveher a Sons, B., N. $Y$. Clty. Brlck and terra cotta.

kuly, Sidney, Ottawa, Ont. BnildIng stone.

Labadie, E. L., Golconda, Nev. Lead ores.

Lafayette Mine, Nevada. Gold, sliver and lead ore.

Lalola, A., Hawthorne, Ner. Gold ores.

Lake Angeline Mine, Inhpeming, Mich. Iron ore.

Lake Superior Mine, Contact, Elko Co., Ner. Copper ores.

Lake Snperior Mine, Impeming, Mich. Ore samples.

Lake Snperior Power Co.. F. H. Clergue, Gen. Manager, Sault Ste. Marle, Ont. Iron, nlckel and copper ores from their various mines and metallurglcal products.

La Panta Mine, S. A. Knapp, Hawthorne, Ner. Gold ore.

Landers, J., Silver City, Nev. Gold ore.
Lanse Graphite Workw, Lanse, Mich, Samples graphite.

L'anse Brownstone Co., MEhigan. Sandstone.

Larkin, Francis, Sing Sing, N. $Y$. Granite and trap.

Lnthrop, J. H., Calumet, Mich. Copper, sllver, etc.

Lawrence Cement Co., Rondont, N. Y. Cement rock and cement.

Lnwrencerille Cement Co, $\mathrm{N}$. $\mathbf{Y}$. Cement rock and cement.

Lennder Connty, Nevada. Antimony, lead, sllver (ruby), gold, Iron, copper.

Lebarge Mine, Madoc, Ont. Iron pyrites.

Ledynrd Mine, Marmora e Belmont Townshlp. Gold ores.

Lee, Thomas N., Texas, Ma. Limestone.

Lee \& Co., R. E., Madoc, Ont. Iron ores.

Legge, Jonhna, Gananoqne, Ont. Green marble.

Lohigh Mining Co., Dickinson, S. D.

Lehigh Portland Cenent Co., New York, N. Y. Cement.

Lehigh Valley Coal Co., Bunalo, N. Y. Coal.

Lemmon, H. E., Carson, Ner. Barlum, molybdate of lead.

Lepper, H. E., Carmon, Nev, Gold ore.

Leonard, J. C., Cambridge, Mr. Clay.

Lewis, w. S., Snow Hill. Brick and tlle.

Lincoln County, Nevada. Mica, salt, gold, sllver.

Lindsay Bros., Nevada. Copper ores.

Lndsay, W. E., Carmon, Nev. Mnrble, gypsum, travertine, onyx.

Lindsay, Wm. P., Texas, Ma. Ilmestone, lime and cement.

Little Dandy Mine, Josephine Co., Ore. Gold ore.

Little Dorris Mine, J. J. Walters, Ont. Gold ores.

Little Jerett Mine, Jackwon Co., Ore. Gold ore.

Little Turtle River Nickel Locations. Copper and nickel ores, pyrrholite, etc.

Livingwton, A., Carwon, Ner. Gold ore.

Logan, H. R.. Carwon, Nev. Phorphyretic pumice. 
Loma Blanca Lithographic Stone Co., Los Angeles, Cal. Lithographlc stone.

Lonnconing Conl Co., 413 Water St., Baltlmore, Mfd. Coal.

Lough Mine. Myrtle Creek, Oregon. Copper ore.

Lovelock, G., Lovelocks, Nev. Nickel, cobalt, copper, etc.

Lowrey, E. D., Qneenstone Qunrry, Ont. LImestone. Dressed base stones.

Uneky Coon Mine, Mine Centre, Ont. Gold ores.

Lneky Find Mine, Josephine Co., Ore. Copper ore.

Incky Hill Mine, Goli Hill, Ore. Gold ore.

Luiwig Mona Co., Victorin Sta., Ont. Smelting and metallurgical works and products.

Lycoming Calcining Co., Garbullsville, N. Y. Gypsum and calcined plaster.

Lynch, Danici, Minerva, N. $Y$. Masslve garnet.

Lynch, F, Minerva, $N$. Y. Verdantlque.

uyon County, Nernda. Copper.

Lyons Pottery Co., Lyons, N. $Y$. Pottery.

MacGregor, Robert, Madoc, Ont. Iron ore.

Macon Co., Mo. Conl.

Madison Co., Mo. Ores and marble.

Madison University, Mndison, Wls. Bullding stone.

Manhattan Mine, Anstin, Nev. Ruby sllver.

Manhattan Mine, Hend once 16 Exchange Place, New York. Gold ores.

Manistique Iron Co. Chnreonl, Iron and mlneral water.

Manley, Pal., Imheming, Mich. Iron ore.

Map of Ontario, geologically colored, wlth localitles of minerals marked, large slze.

Mardis Mining District, Nevada. Gold sulphurettes.

Marcach, W., Int Portnue, ont. Collectlon of sllver and gold ores from Ontarlo.

Markle Lead Co., St. Louis, Mo.

Mnxylund Clay Co., North East. Kaolln.

Maryland Coal Co., 1 Broudway, New York, N. Y. Coal.

Maryland Geological Survey, Baltimore, IId.
Maxyland Granite Co.,725 Equita. ble Bldg., Baltlmore, Md. Granite.

Mraryland Pottery Co., Baltimore.

Maryland Sonpstone Co., Tama.
qua, Pa. Soapstone.

Mayflower Mine, Lower Seine River, Mine Centre, Ont. Gold ore.

Mass. Inst. of Tect., Hoston, Mass. Mayfower Minc, Nevnda. Copper ore.

Mayhugh, J. S., Elko, Nev. Cop-

Muson, B. B., KCeseville, $N$. Sandstone and blue stone.

Mass. Mine, Michigan. Copper ore

Mraterton and Hall, Tucknhoe, $x$. Y. Limestone and marble. Matherva Slate Co., Poultuey, Vt.
Slate.

Maud Mine, Nevadn. Copper ores.

Mnxmon, H. B., Reno, Nev. Gold, sliver, lead, phonollte.

Meclennhan Granite Co., Port De. posit, Md. Granite.

Noted Port Deposit Granlte. Attrac. tlve rustle and finlshed effects archi. tectlvely. Especlally adapted for bridge constructlon, pilnths, ete. Nonabsorbent. Crushing resistance 25,250 pounds square Inch.

MeClure, G. J., Ithnea, N. Y. Sandstone and blue stone.

MeCusker at Son, M. J., Jamewtown, N. Y. Clas and brlck.

MeCoy, Imane, Peekakill. N. Y. Emery.

MeDonougli, J. J., Slateville, N. Y. Clay and brlck.

MeDougal, W. H., White R., Ont. Iron ore.

MeFawn, Geo., Markstay, Ont. Gold ores.

MrGavern \& Co., T. W., Joplin, Mo.

MeKnight, J. H., Corona, Cal. Glass sand.

Melean, J. H., Ironwood, Mich. Iron ore.

MeNnster, H., Burk'* Falls, Ont. Nlckel ores, pyrrhollte, etc.

MeMichae1, H., Poconolze City. Brlck and tlle.

MeNaughton, Sydenham, Ont. Mica.

MeNenl, J. B. \& Co., Baltimore. MIneral palnt.

Mevitte, Wm., Sudbnry; ont. Gold ores.

Mendows Mininm Company, Jackson Co., Ore. Clnabar.

Mellis, F. R., Baker City, Ore. Mlneral exhiblt. 
Yerine \& Sons. M., 1009 W. Bnitimore St., Baitlmore, Md. Pottery.

verrill Coal Co., A. J., Wenternport, Md. Coal.

yerry Monareh Mine, Nevada. Copper ores.

Yerer, H. Fnrmingdnle, $\boldsymbol{N}$. $\mathbf{Y}$. Clay and brlck. Temperlng sand and moldlng sand.

Mca Boller Covering Co., Montreal, Can. Mlca.

Michignn College of Mines. lloughton, Mich. Large photograph case. Ores.

Mldas Diatrlet, Nevada. Gold ores. *

Mlar Mine, S. Snmmerfeld, Hawthorne, Ner. Lead ore.

Mdland Furnaces, Canada Furnace Co., Ont. Smeltlug and metallurgleal works; products.

Mldland Mining Co., Lonaconing, Md. Coal.

Mikailo Mine, T. R. Dercon, Rat Portage, Ont. Gold ore.

Mllen \& Sonm, 'T., Wnyland, $\mathbf{N}, \mathbf{Y}$. Lime and cement.

Mller, A. W., Portinnd, Oregon. Quicksilver ores, metals, etc.

Miller, J. L., Cumberland, Md. Llmestone.

Milton Presned Brick Co., Ontarlo, Can. Pressed brlck and terra cotta.

Mineral Creek Mining Co., Plerce Co., Wash. Arsenical ore.

Minnie Mine, Nevada. Copper ores.

Minto Mine, Miehipicoton Dintrict, Col. Tlsdale, Pres., Simcoe, Ont. Gold ores.

Miss. I. \& Bonne Terre Ry., Mo. Granlte.

Missonri Conl Co., St. Louin, Mo. Hofrat, Jno., Pnrry Sound, ont. Mlea.

Monte Christo MIning Co., Everett, Wash. Arsenical ore.

Montreal de Oregon M. Co., Oregon.

Moose Lake Mine, Little Wablgoon Lake, Ont. Gold ores.

Morgan Mill, Emplre, Nev. Salphate of copper.

Morris \& Strobel, Leroy, $N$. $Y$. Limestone and marble.

Morne Mine, Nevalu. Gold and sllver ores.

Mountain Lion, Josephine Co., Ore. Free gold ore.

Monnt Diabio Mine, Candelaria, Nev. Lead and sllver ores, turquols, plriscite.
Mount Snvage Enameled Brick Co., Mount Savage, Md. Brick and tilc.

Monntain King Mine, Hawthorne, Ner. Lead ore.

Mountain Lion Mine, Oregon. Gold ores.

Mt. Ere Granite Co., Mt. Eve, N. Y. Granite and trap.

Murray, Robert, White $r_{\text {. }}$ ont. Iron ore.

National Nickel Co.. Cottonwood, Churchll Co., Nev. Nickel, cobalt, etc.

Notional salt Co., Waranw. N. Y. Salt.

Natlonal Wail Plaster Co.. Syracuse, N. Y. Gypsum and plaster paris.

Fintlomal Wel, Tile Sewer Co., Syracuse, N. $\dot{Y}$. Web tlle sewer.

reepler, C. T., Catonavilie, Ma. Clay and clay products.

Negannec Mlue, Negannee, Mich. Ore samples.

Nevada Salt nnd Bornx Co. Rhodes Marsh, Esmeralda Co., Ner. Sait, borax, etc.

Nevada Sulphnr Co., Rabblts Hole Springs. Sulphur.

Nevin: \& Son, Jamew, Waiton, N. Y. Sandstone and blue stone.

Newark Mine, Nevada. Silver ore.

Newnrk and Rosendale Cement Co., Rondout, N. Y. Cement rock and cement.

Newburg Pressed Brick and Clay Co., Newburg, Ore. Pressed brick.

New Central Conl Co., The, 1 Brondway, New York Clty. Coal.

New Century Oil Co., Ios Angeles, Cal. Crade oll.

Nerrell, A. P.. Brooklyn, N. Y. Two Amalgamators for plaza and quartz.

New Jersey Sinte Co., Newton, $N$. J. Slate.

New Jermey Slate Company. Newton, N. J. Roofing slate. Newton roofing slate is unequalled for strength and unchanging color. Fifty years' test, chemlcal and physical analysis prove Newton slate superlor to all. Write for prices.

New Jersey \& Pennsylvania Concentratlng Works, Edlson. N. J.

New Jersey zine Co., Frankin, $N$. J. Zinc ore.

Newton, Andrew C., Cremcent, N. Y. Clay and brick.

New York and Ronendale cement Co., Rondout, N. Y. Cement rock and cement.

Nickel Copper Co., John Patterson, Hamliton, Ont. Copper and nlck. el ores, pyrrhotlte, etc. 


\section{The Pan-American Official Catalogue and Guide.}

Nickel Copper Co.. Worthington, Ont. Smelting and metallurglcal works and products.

Niplgon Mining Lands Co., Henry S. Sibley, Detrolt. Copper ore.

Nitch, Arthur B., 301 liamsay st., Baltimore, Md. Bríck and tile.

Noren, Algot, Ironwood, Mich. Iron ore.

Northampton Portinnd renent Co., N. Y. City.

North Star Mine, A. McCharles, Sudbury, Ont. Copper and nickel ores, pyrrholite, etc.

N. Y. Brick and Paving Co., Syracuse, N. Y. Clay and brlck.

N. Y. Hydranlic Press brick Co., Rochester, N. Y. Clay and brick.

N. Y. State Museum. Tron ores. Morlah, Fort Ann, Chateaugay and Tlily Foster. Sandstone und blue stone. Ithaca, Ulster Co., Malden, N. Y., Port Henry limestone and marbie, Hastlngs, Sing Sing, Hudson, Chaumont, Three Mlle Bay, Wulsboro Polnt, South Bethlehem, Lockport. Granlte and trap, Luzerne, Greentield Center. Foundry moiding sand. Samples from Glenmont and Coxsackic.

N. Y. Sillcite Co., N. Y. City. Sillea.

Nye County, Nevada. Gold, silver, lead, antimony ores, phosphates, copper.

onkflela Plaster Mfg. Co.. Onkfleld, N. Y. Gypsum, crushed gypsum, land plaster and plaster of parls.

o'Connor. Dan, Sudbnry, ont. Map of Ontario. (See J. F. Black.)

Oddie, T. L.. Belmont, Nye County, Nev. Cinnabar ore.

o'Donnell \& MacManiman, Nevton, N. J. Bullding stones.

Dest Mine, Silver City, Nev. Gold ore.

ogden Brick Co., Binghamton, N. Y. Brick and clay.

ohm, Fredcrick C., Washington, $D$. C. Rock sections for mleroscoplc use. old Sterling Iron Co., Antwerp, N. Y. Red hematite.

olinghouse Canon, w. D. Linton, Wadsworth, Nev. Gold ore.

olive Mine, Olive Gold Mining Co., Mines Centre, Ont. Gold ores.

oliver, Capt., Ironwood, Mich. Iron ore.

Olson, Silvert, Calumet, Mich. Copper and calclte.

Onandago Mine, Nevada. Silver and lead ore.
Onondaga Coarse Salt Ansocia-
tlon, Syracuse, N. Y. Salt.

Onondagn Vitrified Briek

Warners, N. Y. Clay and brick Co,

Ontario Carlide Company, otta.
wa, Ont. Calcium carbide.

Ontario Granhite Co., nttawa.
Graphite from Black Calabogie, Ont.

Ontario, man of large size, show. lng transportation connections at Sauit Ste. Marie, Ont., by colored la.
candescent lamps.

ontario, man of large nize, geo. loglcaily colored with mineral local. itles, etc., marked.

Ontrio Smelting Co., Sudbury Massey Sta., Ont. Copper ores.

ophir Canon, Ophir, Nye County, Nev. Sllver ore.

Ophir Mining Co., Virginla, Nev. Gold and sllver ore.

Oregon Bonanza, Josephine $\mathrm{Co}_{\text {“ }}$ Ore. Gold ore.

oregon Copper Co., Portland, Ore. Copper and goid ores.

oregon Lime Co., Hutington, Ore. White marble.

Oregon Mineral Watcr Co., ore. gon.

Orford Copper Co., and Ontario Smeltlng Works, Copper Cllff, Ont. Smelting and metaliurgical works and products.

Ormaby County, Nevada, Conper, graphite, pyrites of iron, gold, pumice.

oronoga Mines, Jnswer Co., Mo. Zinc ores.

osborne, Marcellis \& Co., Upper Montclair, N. J. Bullding stones.

Ossining Iine Co., Sing Sing, $x$. Y. Lime and llmestone.

Onimette, J., Plattsburg. N. Y. Clay, brick and tempering sand.

Oursler, E. W., Westminster, Md. Brick and tile.

Overman Mine, Gold Hill, Nev. Aragonlte water box.

Oren Sound Portlnnd Cement Co., Shallow Lake, Ont. Portland cement.

Ozark Mine, H. R. Logan, Carson, Nev. Pyrites.

Preific Const Borax Co., Columbus, Nev. Crude and refined borax.

Pacific Conper Co., S. A. Knapy, Hawthorne. Nev. Copper ores.

Pacife Corst Co., Seatte. Wash. Bituminous coai.

Palmer \& Co., H. S., N. Y. Citr. Brass model cement bollow brick. making machlne. 
Pamilco Mine, J. Forbes, Hnwrthorne, Nev. Gold ores, model. Panaca District, Nevada. Maganese. Panting, J.A., Oregon, Photos of Gold Hill ulines.

Park, Alec., Eganville, Ont. Miea, Crystals of apatite, sphene, etc.

parmenter, D., Potsanm, N. $Y$. Sandstone and blue stone.

pirry, R. W., Reno, Nev. Gold, sllver and lead ores.

parry Sound Copper MIning Co., Parry Sound, Ont. Copper ores.

pasalc Qunrry Co., Avondale, N. J. Building stones.

Pattion, G. C., Bloomingtom, MI. Cosl.

Pal, F., Ely, White Pine Connty, Zlrcons, Nev. Copper, lead and sllver oreg.

Peach Bottom Slate MfE. Co., Delto, $\mathrm{Pa}$. Slate.

Peach \& Co., Frank, Granite, Ma. Granite.

Peavine Dintrict, Nevada. Copper, sllver ore, gold ore.

Peck, Rlchard, Faxt Bethany, $N$. I. Clay, drain tlle and fire proofing.

Pedilcord \& Son, J. II., 12 North St., Baltimore, Md. Granite.

Peerles Slate Co., Delta, Pa. Slate.

Pearhyn Sinte Co., Midale Gran vllle, Ont. Slate.

Penrod, E., Glko, Nev. Gold ore. Pere Marquette Coal Co., Saginat, Mlch, Coal.

Perine \& Son, N., Baltimore. Pottery.

Permanent Exlibit, Portiand, Ore. Asbestos.

Perryvile Granite Co., Perryvile, Ad. Granlte.

Phillps, C. A., Parry Sound, Ont. Copper ore.

Philips, Hush J., Sallsbury, Ma. Brlck and tile.

Plcher Leai Co., Joplin, Mo. Lead. Pickett Creel- Mine, Josephine Co., Ore. Black manganese.

Pledmont and Georses Creek Coal Co., The, Frostburg, Md. Coal.

Pledmont-Cumberland Conl Co., Pledmont, W. Va.

Pledmont Mining Co., 213 E. German St., Baltimore, Md. Coal.

Plke Mfg. Co., Pike station, N. H. Carborundum.
Pine Monntain District, Nevada. Concentrating ores.

pine Nut District, J. Rayeraft, Carson, Nev. Gold ores.

Pirn Oil d Mining Co., Plrn, Cal. Crude olls.

Polar Star Mining Co., Portland, Ore. Gold and copper ores.

Poole, C. E., Turganore. Limestone.

Poorman Mine, Ely District, N. P. Dooley, Pioche, Nev. Sllver.

Portage Blue Stone Co., Portage, N. Y. Sandstone and blue stone.

Portage Entry Sandatone Co., Mlchlgan. Sandstone.

Potee Broø., Brooklyn, Md. Clny.

Poteel, Z., Cockeysuille, Ma. Limestone.

Pratt, Dr. J. H., Chapel Fili, N. C. Gems of N. C.

Pratt, John Hyie, Chapel 11ili, N. C. Coll. ex. of N. C. gems.

Preston Brick Co., Hornelimville, N. Y. Clay and brlck.

Pritchard, A. I., Pleasantrille, N. Y. Limestone and marble.

Proctor Bros., Delta, Pa. Slate.

Puenta Oil Co., Los Angeles, Cal. Models of oil wells.

Puerite Oil Co., Cal. Mudel oil wells.

Pryor, Jas L., Hagerstown, Md. Brlck and tlle.

Pyne, R. A., Toronto, Ont. Graphite.

Queen City Brick \& Tile Co., Cumberland, Md. Brlck and tile.

Queen of Bromze $M$. Co., Oregon.

aneen of Bronze Mine, Waldo, Ore. Copper ore.

Queonstown Qunrry Co., St. DaFld's, Ont. Bullding and ornamental stones.

anincy Mine, Michigan. Ore and mllled copper.

Railrond District, Sknggn, Elko Co., Nev. Copper, gold and silver ores. Rainy Lake Mining and Porer Co., West Superlor, Ont. Gold ores.

Ralph Calrns, Walton, N. T. Flagstone.

Randolph, B. H., Frostburg, Md. Sandstone.

Raudolph Mine, Mine Centre, Ont. Gold ores.

Rattlesnake Mining Co., Oregon. Gold ores.

Raycraft, E., Carson, Nev. Copper ores, Iron ores. 
Raymond \& Ely, Ely, Ner. Silver ores.

heed, C., Eurelka, Nev., Lead ores. heed, W., Nevada. Ixon ores.

Reeder, J. T., Calumet, Mich. Metals and ores.

Rees Seavel, Yelíville, Ark. Arkansas minerals.

Reeves, James A., Joplin, Mo.

Regina Mine, ont. Gold ores.

Reidel \& Hengle, Portind, ore. Buliaing stone.

Relger, Henry Y., 50\% N. Paca St., Baltimore, IId. Granlte.

Reilly, Wm., Colileskill, $N$. $Y$. Limestone and marbie.

Retsof Mining Co., Retsor, N. $Y$. Salt.

Rex oil Co., The, Los Angeles. Crude oil.

Rhode Island Graphite Co., Providence, R. I. Graphlte.

Rich Hill Zine Works, Joplin, Mo. Zinc.

Richardson \& Son, James, Kingston, Ont. Feidspar.

Rleger, H. P., Baitimore, GranIte.

niter, H., Reno, Ner. Iron ores.

intenhouse, N. M., Bnitimore. ciay.

Roberta, S. P., Nevada. Copper ores.

Robins Conveying Belt Co.. N. $Y$. City.

Robinson, Hiram, Worthington, Ont. Copper and niciel ores, pyrruolite, etc.

Roche Harbor Iime Co., Roche Harbor, Wash. Ifmestone and cement.

hochester Brick and Tile hig. Co., Rochester, N. Y. Clay and tile.

Rock Lake Copper Mining Co., A. S. Burross, Mgr., Bruce Mines, Ont. Copper ores.

Roddy, D., Thurmont, Mil. Limestone.

Rogers, Brown at Co., Bufialo, N. Y. Coal.

Rogue River Milling Cu.. Gold HIIl, Ore. Gold ore.

Rogue River Miling Co., Jackson Co., Ore. Gold ore.

Roof, Wm. A., Westminster, Mu. Limestone.

Honnd Top Hydrnulle Cement Co., Hancock, Md. Iimestone, lime and cement.

Royal Blue Mine, Mo.

Russell, H. M., Los Angeles, Cal, Gold quartz.
Ryan, J. R.. Virginia City, Jer,
Comstock ores.

Snam, Henry, Hancoek, Mich. Ar.

Sakoose Mine, Jyment, Ont. Gold
ores. Salmon Bros., Ledgerrood, N. J.
Buliding stones.

Sandasky Portlanil Cement $\mathrm{C}_{0,}$ Sandusky, Obio. Cements.

San Diego Chumber of Conmerce, San Diego, Cal. Lipidolite, lithia and mica.

Snnford, C. I., Sonthola, X. Y. Ciay, brlck and tempering sand.

San Lnens Minc, Nevnda. Sliver and lead ores.

Sarage Mountain Fire Brick Co, Frostburg, Md. Brlck and tile.

Sawbill Mine, Ont. Gold ores.

Sayre A Fisher Company, Sayres. Fllle, N. J. Enamei brick.

Scane, W. W., Chatham, Ont. Mineral water.

Selineidex, Helen M., Eureka, Nev. Special exhibit.

Sehneler, Jolin, Magnetaran, Ont. Copper and nicliei ores, pyrrholite, etc.

Sehool of Practical Scienre, To. ronto, Ont. Coliection Ontario dressed stones and minerais. Large apatite crystal.

Schwind Quarry Co., 302 Fidelity Bidg., Baitimore. Granite.

Scramble Mine, Out. Goll ores.

Seneca stone Co., Daltimore. Sandstone.

severance, S. M., Fayetterilie, $\mathrm{N}$. Y. Gypsum.

Seymour Mine, Madoe, Ont. Iron ores.

Shaver, A. G., Connjoharie, N. Y. Limestone and marbie.

shamnhnn, James, Tribes Hil, N. Y. Limestone and marbie.

Sliear \& Co., A., Dunnesburg, N. Y. Sandstone and biue stone.

Shehan Bros., Doe Run, Mo. Granite.

Shields, J. C., Hancock, Mich. Copper.

Shorty Hope M. Co, Oregon.

Shreve \& Co., Baltimore. Bailding sand.

Slirump. $F$. W., Montelair, N. J. Buliding stones.

sidney Irnly, sranite, ottawa, Ont.

Sierra Nernda Mining Co., Virginia cits, Nev. Goid and silver ore.

Signal Oil Co.. Frankliu, Pa. Iabricating and lighting oils. 
gller Star Dintrict. W. J. Douglas, Sodavllie, Nev. Gold oles.

slls-Eddy Mien Co., N. K. C. Mten. stnclair, Maicolm, Camberland, Ild. Coal.

ginclatr Mining Co., Whe, Cumberland, Md. Coal.

sirdar \& Crown Hoint Mines, 'Poropto \& Western Mlning Co., Tolouto, ont. Gold ores.

sikl Copper Co., Grants Puns, oregon. Copper ore and copper metal. str Magles Goli Mining Co., Olympia, Wash. Ore comblning gold, sllver, copper and lead.

smith, B. G. \& J. C., Conowingo, Md. Flint.

smith, Henry S., Sharon Springw, N. Y. Lime and llmestone.

smith, J, Elko, Nevnda. Copper ores.

Sath, Willam, Cainuet, Mich. Copper, quartz, etc.

smith, W. H., North Plainfela, $N$. J. Bullding stones.

Sinth \& Co., J., Syaenham, Ont. Plnk marble.

Smith \& Fanning, Dover, $N$. J. Bullding stones.

smyth, W. K., Ryalel Bank, Ont. Copper ores.

sophia Mine, Marmora d Belmont. Ont.

South Dover Marble Co., South Dover, N. Y. Marble.

gouthera Klonaike District, Nerada. Gold and sllver ores.

sonthwest Miner"' Ass'n, Los Angeles, Cal. Speclmens gold, sllver, lead and copper oles.

spears, S. P., Rarleigh IIeIghts, Md. Glass sand.

Spence Bros., Bruce Mincs, Ont. Trap rock.

Standaxd Oll Co., N. Y. Clty. Petroleum, Its occurrence and its produets.

Standard Sewer Pipe Co. Rochester, N. $Y$. Salt glazed sewer plpe.

Star Mine, Nevada. Silver ore.

State of Geormin. Collective Ixhlbit of ores and bullding stones.

state of North Dakota. Coni speclmen.

state Ine District, W. P. Dooley, Ploche, Ner. Sllver ore.

Stanb, G. R., Wakefield, Ma. Limestone.

Steambont Surins, J. Burke, Reno, Ner. Clnnabar, arsenlc, alumlnum and gold.
Steln a Hoericke, Pliladelphin. Linc and lion ore.

Steiner mine, Nevila. Gold nual sllver ores.

Stewant, F. J., Hamilton, Ont. Gananoque slgemites.

St. Francois Co., Mo. Tarious ores.

St. Grinevicve Co., MIo. Gies nnd Calcite.

St. Joseph Lead Co., Boino Texre, Mro. St. Lawrence Marble Co.. Gonver neur, N. I. Limestone and marble.

Stoble Mining Co., Sault St. Mnrie, Ont. Copper ores.

Stock. H. M.. Sernntom, Pa. Safety lamps and publications.

Stockton Stone Co., Stockton, N. J. Bullaing stones.

Storey Comnty. Nevria. Great Comstock lode ores, model of tlmberlug.

Strayor, David S., Ridgely, Ma. Brick aud tlle.

Strickland, I. T., Peterboro, Ont. Ulthographic stone.

St. Thomns District, D. Bonell. Riovllle, Ner. Gold, sllver, rock salt, etc.

Stoble Mrine, Desbarats, Ont. Copper oles.

Stonter, 5 . K.. Emmittaburg, Ma. Brlck and tlle.

Strom, Andrew, Tronvood, Mleh. Iron ore.

Stummel, J. W., Walkersvile, Ma. Limestone.

Sturgeon Lule Mining Co. St. Cathalines, Ont. Gold ore and free gold specimens.

Sugar Pine Mine, Tosephine Co. Ore. Free gold ore.

Sultann Mine, Wm. Stroug, Rat Portage, Ont. Gold ores.

Sultann Nielcel Mine, Worthington, Ont. Copper aud nlekel ores, pyrrbotite, etc.

Sunday, D., Harmony Grove, Ma. Llmestone.

Sunrise Mine, $T$. 1 . Oadle, Belmont, Nye Co., Nev. Clnnabar ores.

Swanhilda Mine, H. R. Logan, Carson, Nev. Copper ores.

Srvayne, E. L., Ios Angelen, Cal. Crystal salt.

Symonds, A. D., Elmirn, N. $\mathbf{Y}$ Sandstone and blue stone.

Symmes, H. R.. Thnnäe Bay Dixtrict, Ont. Gold ores. 
The Pan-American Official Catalogue and Guide.

Syracnae Pottery Co., Syracune. Flower pots and seed pans.

Table Monntain District, Nevala. Slllcate of copper.

Tamarack-Owcoln Mine, Michigan. Copper ore.

Taney E Co., Mo. Lend and xinc ores.

Tavenier \& Johnson, Closter, $\mathbf{N}$. J. Bullding stones.

Texas Lime Co., Texas, Ma. Mimestone.

Thomax, B., Paterson, N. J. Buildlng stones.

Thomas, Eran, Prospect, N. $Y$. Llmestone and marble.

Thomas, Francis, Troy, N. Y. Slate and slate palnt.

Thomas, Loren, Waterloo, N. $\mathbf{Y}$. Llmestone and marble.

Thompжon, Wm., Reno, Nev, Alum. Thorn Cement Co., Bufialo. Portland cement.

Thunder Bay Distriet, Dr. Fmoxy, Toronto, Ont. Iron pyrites.

Tobino, Mrs. D., Nevada. Gold ores.

Todd, F. C. C Co., Sallsbary, Ma. Brlck and tlle.

Tonapri District, T. L. Oddie, Tonopah, Nye Co., Nev. Gold and sllver ores.

Tower \& Company, A. E., Ponghkeepsle, N. Y. Iron ores.

Travis \& Kinsbury, Hale Eddy, N. Y. Flagstone.

Trent Valley Peat Fuel Co.. A. I. Davls, Peterboro, Ont. Peat fuel.

Triggs Mine, Ont. Gold ores.

Tri Mountain Mine, Michignn. Ore and milled copper.

Trombly Minc, Lake Superior, North Shore, Ont. Copper ores.

Tuscarora District, Nevada. Stephanlte and ruby sliver ores.

Twentieth Century Trading Co., Gold Ores, Mlnes, Gold Rock, Ontarlo. Modern Machlnery, Great Ore DeposIts, Thlrteen Divldends pald since May, 1000. Treasury shares for sale for enlarging plant to increase Dividends. Write for prospectus. Address, Anthony Blum, Prest., 35 Court St., Boston, Mass.

Twining of Co., S. B., Stockton, $\mathbf{N}$. J. Bulldlng stones.

Underhill Brick Co., W. A.. Croton Polnt, N. $\mathbf{Y}$. Clay and brlck.

Union Akron Cement Co., Bufialo, N. $\bar{Y}$. Cement rock and cement.
Unon Miniug Co.. Mount Sarage,
Md. Brlck and tile.

Union Talc Co, New York, X, Y.
Talc.

United States Marble Co.. Spo.
kane, Wash,

Univerwity of California, Berkely, Cal. Publlcatlons.

University of Chicago. Mineral

Unircrsity of Colorado, Colorado Sprlngs. Publicatlons.

Utica Stone Co., Franklin, Pa. Van Etten. James S., Granite, u.
ster Co. Mlllstone.

Variegnted Marble Co., Roseburg, Ore. Four varletles varlegated mar.
ble.

Vassar College. Petrotonie.

Veri Antique Marble Co., Thur. man, N. Y. Limestone and marble.

Vesuvius Mine, Nevada. Carbo. nate ore.

Victor Mining Co., Josephine Co., Ore. Gold ore.

victoria Mine, W. Smith, Caledo. nla, Ont. Gypsum.

Victoria Mines, Mndwig Mond Co. Victoria Sta., C. P. R. Copper, nlckel ores, pyrrhotite, etc.

Viking Mine, J. D. Curran, Rat Portage, Ont. Gold ores.

Vivian, Johnson, Houghton, Mleh.

Vivian Mine, Nevada. Gold ore.

Von Moltike Mine, Jackson $\mathrm{Co}$ Ore. Gold ore.

Vulcan Mining Co.. Siegrelville, Esmeralda Co., Nev. Copper ores coal.

Vulcan Mining Co., Vulean, Mich. Ore samples.

Vulcanite Portland Cement Co, Vulcanite, N. J. Cement.

Wakeflela Fire Brick Co., North East, N. Y.

Wa11, J., Carson, Ner. Copper ore.

Wallbriage Mine, Madoc, ont. Iron ores.

Waiters, A. J., Motters, Mu. Lme. stone.

Walker Bros., Merriton. Ont. Bullding and ornamental stones.

Walker Bros., Thorold, Ont. Lime. stone.

Waiton Marble Co., Port Ienry, N. Y. Limestone and marble.

Warsaw Blue Stone Co., Warsaw, N. Y. Sandstone and blue stone 
The Pan-American Offcial Catalogue and Guide.

Washington Co., Mo. Bnyplte and lead ores.

Wrahington Junetion Stone Co., Point of lioeks, Mrd. Marbie.

rashoe County, Nerada. Gold, silver, copper, cinnabar, lime, arsenic.

vatson-Lny Conl Co., Bnrumm. W. Va. Coal.

Waslnnd Portlnni Cement Co., Tarlaud, N. Y. Lime and cement.

Weber, Albert, Baltinore. Granite.

Welcome Mine, W. H. Kirk, Creson, Nev. Graphite.

Teldy, H. A., Tamaque, Pn. Soapstone.

Weller. Wm. F., Granite, Ma. Granite.

Wells Hall, Oprlensbnrk. N. Y. Paint, mortar color and iron ore.

Welsbach Light Co., Philn. Pn. Ex. Iridosminm.

Terner Bros., Ellicott City, Ma. Granite.

Westmorcland Conl Company, office 224 S $3 d$ St., Philadelphla. Mines, Westmoreland County, Pa. "Gas coal of the very highest grade, contalning nearly 40 per cent. of volatile matter, singularly free from sulphur and asl, of great use in making both illuminatlng and producer gas and in raising large quantitles of steam."

White, J. H. \& R. H. Allen, Sarntoga Springs, N. Y. Granlte and trap.

White, Josemli H., Easton, Ma. Clay and prod.

Whiteford Green Marble Co., Whlteford, Md. Marble.

Whitefori, S. J. \& H. C., State Hlll, Pa. Flint.

Whitehnrst, J. T., BnItimore. Mineral paint.

Whitehurst \& Co., J. T., Columbia Are., Baltlmore, Md. Mineral paint.

White Pine County, Nevada. Silver, lead, gold, iron, copper, ete.

Whitner Marble Co., Gonverneur, N. Y. Limestone and marble.

Whitney Mine, Gold Hill, Ore. Gold ore.

Widelind, Geo., Reno, Nev. Silver ore.

Wilbur Mine, Wm. Caldwall, Lanark, Ont. Iron ores,
Wiley, F. S., Port Arthur, Ont. Silver ores.

Wilholt Springs arineral Wnter Co., Portland, Ore. Mlneral water.

Willinms, Willam, Durhamville. Glass sand.

Wlilinms of Co., C.. Blgelov, $\mathbf{N}$. Lime and llmestonc.

willamson \& Co., John N., New York. Sand and clay.

Wilson, J., Terington, Nev. Copper orc.

Wilson, Wm., Pine Grove, Ner. Gold ore.

Windsor Snit Works, F. Henderson, Windsor, Ont. Salt.

Winkle Terrn Cottn Co., Mo.

Winnemneen Mountain District, Nev. Copper ores.

Witherbee, Sherninn of Co. Magnetite from Mineville.

Wolverine Mine, Miehignn. Copper ore and milled copper.

Wood, Tingley S., Lendrillc, Col. Gold nuggets.

Woods Investment Co., Vietor, Col. Minernis.

Woodcoch Ninthaniel, Loring, Ont. Copper ores.

Worcester Snlt Co., Silver Springw, N. Y. Salt.

Wright, J. E., Baltimore. Fire brick.

Wright, Prof. L. I.., Ironvood, Mleh. Iron ore.

Yankee Boy Mine, Douglass Co. Ore. Copper ore.

Yellit, T. \& Co., Texan, Mi. Limestone.

Tellowhorn Mine, Josephine Co., Ore. Gold ore.

Fellow Jacket Mining Co.. Nerada. Gold and sllver ore.

Terington, J. A., Nevnda. Gold, sllver, lead, Iron, sulphur, viriseite, etc.

Yneen Mfg. Co., Low Angeles, Cal. Asphalt.

Yukon oil Company, Los Angeles, Cal. Crude olls.

Zenith Mine, Thnnder Bny Distrlet, near Rosspoit, Ont. Zlnc.

Zonek at Co., Cavetown, Mr. Limęstonc, lime and eement, 


\section{Firms oxhibiting in Geological Survey of New Jersey.}

Allen Granite Construetion Co., Waterloo, N.J. Bullding stonc.

Alplin Portinnal Cement Co., Alpha, N.J. Cements.

Amerienn Copper Mining Co., Somerville, N. J. Copper ores.

Bartell, Wun. E., Mnrtinsville. N. J. Building stoue.

Birmey, David, German Valley, $N$. J. Buildiug stoue.

Heiseulntte, G. W., Ridgefield, $N$. J. Building stone.

Hiberuia Mine, Hibernia, N. J. Iron ores.

Lymnn Kice, German Valley, N. J. Buildiug stouc.

New Jersey and Pennstivamin Concentrating Works, Edlson, N. J. Iron ores.

New Jersey Slate Co., Newton, $N$. J. Siate.

New Jersey Zine Co., Frankliu, N. J. Zinc ores.

o'Donmell o MneMamimau, Newton, $N$. J. Building stone.

osborne, Mareellis \& Co., Upper Moutclair, N. J. Building stone.

Pnssnie City Brown Stome Co., Passalc, N. J. Building stone.

Passnue Quniry Co., Avoninle, . J. Building stone.

Salnon Bros.. Ledgerwoor. $N$. $J$. Bullding stone.

Shrnmp. F. W., Montelnir, N. J. Building stone.

Smith, W. I.. North Plninfleld, N. J. Bullding stoue.

Smitl o Fanning, Dover, $N$. J. Building stone.

stockton Stome Co., Stocktom, N. J. Bullding stone.

Tavenier \& Jolnuson, Cloxter, $N$. J. Bullding stone.

Thomas. B., Patersou, N. .T. Building stone.

Twining \& Co.. S. E.. Ltal., Stockton, N.J. Buliding stone.

Vulcanite Portlund Cement Co., Vulcanite, N. J. Cements.

\section{MEXICO.}

Aguilar, Francisco, Ures, Sonora. Gold and silvel ores.
Alinuman, Mignel, Chihuahna,
Chilhualiua. Silver ores.

Bilcerton, Je., Mocternma, Sonora.
Sllyer ores. BInneo, Angel, Sultepec, Mexico.
Sliver ores.

Cardenas, Amalor, Jimulco, Coahuina. Mcxican onjx.

Comision de Exposicion de San Luis Potosi, San Luls Potosí. Míneral

Compnnia Cnrbonifern de Fuente, Coaluuila. Coal specimen.

Compania de Fumdicion de Fierro I Manufacturera de Monterey, Nuero Leon. Mining cart.

Companin Del Real Del Monte y Pachuca, Pachuca, Hildago. Míneral collection.

Companin Del Real Bel Monte $y$ Pachuea, Pachuca, Ilidalgo. Photo. graplic mining maps.

Compania Francesa Minera de San Pedro, Aitar, Sonora. Silver ores.

Companin Mexieann he Cal Hidrauliea, Cemento $\$$ Material de Con. struccion, S. A., Mexico. Building
stone. D-W.

Comprnin Mimera "Crny $\boldsymbol{y}$ Anexas," Mexlco. Qulcksilver ores. D-F:

Compamin Minern de Bnjnn. Monterey, Monterey. Silver ores.

Companin Minera de Penolen, Mapiml, Duraugo. Lead and silver ores.

Compania Minera le Pinnco, Mazatlan, Siualoa. Mineral collection.

Compania Minera de Snn Rafael y Anexas, Zacatecas, Zacatecas. Sliver ores.

Comprnia Minera Del Boleo, Baja Cailfornia. Copper ores.

Comprnia Minera Fundidnra Afinadora de Monterey, Monterey. Lead and silver ores.

Compania Minera. Lampaxos, Naevo Leon. Silver ores.

Compania Minera "Ln Cantellana y San Ramon" Aluacatlan, Teplc. Sllver ores.

Companin Minern "La Fraternal," S. A. Lampazos, Nuevo Leon. Zinc orcs.

Compania Minera "Ina Palma," Sombrercte, Zacatecas. Sliver ores."

Creel, Enrique, Chiliuahua, Ch!huahua. Silver ores.

Creston Colorndo Mining Co., Hermosillo, Sonora. Gold and silver ores.

Cruz, Rafael, Chihnahua, Chihuahua. Silver ores. 
ethera,

wrolt Mexican Company, SuItepec Uexico. Sllver ores.

grao Venancio, Lamparos, Nuso Leon. Sllver ores.

pres Francinco, Arimpe Sonora. witrer ores.

pindicion de Sinnion, Manatian, sinaloa. Foundry photographs.

aran Serapio, Guadalnpe, Zacatecas, Sllver ores.

Grela, Francinco H., Tactabaya. silver ores. D-F.

Gareia, Lucas R., Lampazos, Nuero Leon. Sllver ores.

Grela Trinilad, Mexico, D. F. Siltrer ore collectlon.

coblerno Del Gatado de Agnascalientes, Aguascalientes, Tepezala y dsientos Dcampo. Silver ores.

cobieruo Del Entado ale Durango, Durango. Building stone.

Gohierno Del Estado de Durango, Durango. Mexlcan onyx.

Coblerno Del Cstailo de Durango, Durango. Natlve sulphur.

coblerno Del Fstado de Dnraingo, Durango. Silver ore collectlon.

foblerno Del Estado de Guanajuato, Gurnajuato. Bullding stone.

cohlerno Del Estado de (inanaJuato, Guanajuato. Mlneral collectlon. Gobferno Del Entado de Mexico, Toluca. Sllver ores.

Goblerno Del Estado de Sinnlon, Iszatlan, Slnaloa. Ore collectlons.

Gobterno Del Extado de Zacatecas, Zacatecas. Sllver ores.

Gomez, Franciseo, Hildago Del

Parral, Chlhuahua. Sllyer ores.

Gran Fundicion Central ile Aguascallentes, Agunscallentes. Map and products of the foundry.

Gran Fundicion Central Mexicana de Aguascallentes, Aguascallentes. Sllver ores.

Gregr, W., Moctezuma, Sonora. Copper ores.

Henlart, Anrelio, Chareas, San Luls Potosl. Antlmonlal ores.

Honey, Micnxalo, Mexico. Iron ores. D-F.

Hojon Antonio Moctezuma, Sonora. Silver ores.

Internatiomal Mining Company, Nleves, Zacatecas. Photographle mlnlng vlews.

KIng, J. K. M., Moctezuma, Sonora. Sulver ores.
La Dura Mill und Miming Co., Alamos Sonora. Sllver ores.

La Dura Mining nud Mining Co., Hermosllo, Sonora. Anthraclte and natural coke.

Lejeune, Fermando, Minilas, Zucatecas. Sllver ores.

Maiz Jonquin, Monterey, Nuevo Leon. Lead and sllver ores.

Martinca, Baca Ealundo, Mexico. Mlneral collectlons. D-F.

Mrampir Copper Co., Concepcloa Del Oro, Zacatecas. Sllver ores.

Mrendona Presbitero, Gnamajuato, Guanajuato. Mineral collection.

Merquital Mining Co., Merquital Del Oro, Zacatecas. Silver ores.

Mocternmia Copper Mine, Moctez.uma, Sonora. Copper ores.

Morenean, Framcisco, Altar Sonora. Silver ores.

Municipaliand he Tepeji siel Rio, Atotonilco, Hidalgo. Llme stone.

Munieinnidad de Tepeji Del Rio, Atotouilco, Hidalgo. Marbles.

Munox de In Camarn Enrifue, Mexico. Miṇeral collectlon. D-F.

Nesociucion de Candelaria $y$ Anexas, Plnos; Zacatecas. Gold and sllver ores.

Negociacion Minera de Santa Maria de Guadalupe, Guadalupe, Zacatecas. Lead ores.

Nerocincion Minern Del Progreso, Trlunfo, Baja, Callfornla. Sllver ores.

Negociacion Minera Reaturadora, Purisima y Anexas, Norla de Angeles, Pinos, Zacatecas. Sllver ores.

Negociacion, Sauceda, Zacatecas. Collection of sllver ores.

olimnn, Mnnuel, Prebla, Puebla. Green streaky Mexlcan onyx.

Ortegn, Diego $L_{\text {., Arime, Sonora. }}$ Silver ores.

Ortegn, Diego M., Altar, Sonora. Sllver ores.

Pedrazini. Juan, Arimpe, Sonora. Sllver ores.

Pereira. Manuel, Mocterana, Sonora. Sllyer ores.

Percira, P.. Lnmpazos, Nuevo Leon. Sllver ores.

Robinson, W. H.. y Socios, Oaracn, Mexico. Lead ores.

Rule, Francisco. Pachuca, Midrigo. Mlning maps.

Rule, Frnncisco. Pachuca. Hidalgo. Sllver ore collection. 
San Carlos Copper Co., San Jose, Tamaullpas. Ore collectlon.

Santa Cruz Francisco, Colima, Colinna. Building stone.

Santa Cruz Francisco, Collma, Colima. Marbles.

Sellerier, Carlos, Mexico. Metallic ore collection. $\mathrm{D}-\mathrm{F}$.

Snith, J. E., Mocteznma, Sonora. Silver ores.

Sombrerete Mining Co., Sumbrerete, Zacatecas. Metallic ore collection.

The Chiapas Mining Co., Pichucalco, Chlapas. Sllver ore, Sante Fe Mlne.

The Dos Cabelas Mining ro. Silver ores.

The Mexican Gold and silver Recovery Co., Hermoslllo, Sonora. Gold and sllver ores.

The Mocteruma Copper Co., Lnm Pazos, Nuevo Leon. Sllver ores.

The Snnta Rosnlin Mining Co., Arlzpe, Sonora. Sllver ores.

Torres, F., Snn Luis Potosi. Silver ores.

Vnllejo, Loreto, M.. Ahnacntian, Tepic. Territorlal map of Teplc.

Vallejo, Loreto M., Ahnacntinn, Tepic. Sllver ores and photographs of Ceboruco Volcano.

Ybarra, Jesus Y., Pinos, Macatecas. Sllver ores,

\section{IOAHO.}

Ealley, D. W. Coppex.

Bary Bryan Mine. Silver and copper.

3. B. I. Gold Co. Gold and copper.

Bibby, S. E., Grangeville. Ox Ankle Jolnt. Big Buffalo Mine. Gold and cop-
per.

Blackbird District. Copper ore. Bledsoe, Capt. Gold and ilver.

Blogghor, H. J. GoId, silver and copper.

Blue Jacket Mine, Seven Devils. Brisben, Earard, Absedion. Hrisben, Edward. Gold bossom
rock.

Brisben, Fdrard, Gray copper
and galesia.

Brisben, Edward. Jasper.
Brisben, Edrvara. Lead.

Bull Dog Minc. Copper.

Bullion Mine. Lead and silver.

Bunker Hill nud Sullivan Concen. trating Co., Wallace, Idaho. Silrer
and lead concentrates.

Carston Mine, Copper ore.

Distrlet.

Columbia Mine. Gold.

Coresus Mine. Gold and copper.

Cracker Jack Buffalo Hump. Gold.

Delamar Mining Co. Gold.

Democrat Mine. Lead and nilver.

Demham, J. M., Grangeville. Gold
quartz.

Dewey Mining Co. Copper and
gold.

Dixie Mining District. Gold ore, Dixie Qneen Mine. Gold.

Eastern Mining Co. Gold.

Gben Mounts. Copper.

Ellen L. Mine. Gold.

Evergreen Mine. Gold and concentrates.

Fourth of InIy Mine. Gold ore.

Gray, Ben $R$. Inon.

Grangeville Mine. Gola,

Great Eastern Mine. Copper.

Hnwley and Pritchet, Gold and silver.

I. $x$, L. Mine. Concentrates.

I. $x$. L. Mine. Gold, silver and copper ore.

Idmho County. Copper ore.

Jnmbo Mine. Concentrates and gold.

Karstan nnd Gattereisen. Copper.

King Mine. Gold, wilver and lead.

Lench, P. H., Grangeville. Gold quartz and placer gold.

Lernhi connty. Petrified wood.

Liberty Mine. Gold and copper.

Little Florence Mine. Gold and copper.

Mammoth Mining Co. Gold.

Mammoth Mining Co. Lend and sllver.

MeDufie, J. T., Idalyo Co. Alum.

MeDufy, J. T. Gold ore.

MeFaiden, H. J. Gold ore.

Mclinley, Wm. Gold ore.

Middleman Mine. Gold and ailVer. 
The Pan-American Official Catalogue and Guide.

fola Iline. Gold nnd wilver. whee Co. Onyx and opalized pood. th to dbling. Gold. presldent Lode. Gold. red Clond Mine. Lead, milver, silleate and Iron.

seed George K. Gold.

Hlee, L. C. Lona rock.

gice, I. C. Petriffed woed and opglized wood.

Rice, L. C. Silver and lead. seren Devils Mining District. seren Devils. Pencock conper. imall Boy Mine. Gold and copper.

state University Muscum. Gold, copper, silver and lead.

state University. Slemhezite, rellow ochre, sheet mica and Indian curlos; specimens of sllver and lead from Coeur d'Allne district.

st. Louis Mine. Gold and copper. Taylor, W. H. Opal mines.

raylor, W. H. Opal rock.

thunier Monntain Mine, Caswell Bros. Gold.

Mp Top Mine. Gold and silver.

Trade Dollar Mining Co. Gold and silver.

Travelers Mine. Gold.

Tncle Snm, Blackbird Distriet, Copper.
Westford Gold Mintug Co. Copper and gold.

wilson, Edgar. Asbentos.

\section{WASHINGTON STATE.}

Burbridge, G. L., Spokane. StentIte.

Burnett, C. H., Enrnett. Knolin and manufactured products.

Crown Point Mining Co., Sentle. Molybdenlte.

Shedi, Prof. S., Pnllman, Relief map of Statc.

Skngit Conl and Coke Co., Cokedale. Cokc and coal.

State of Washington. Ores of gold, silver, copper, lead, Iron antlmony, arsenlc, tellurlum, and molybcdenum

Minerals : Graphite, realgar, orpin. ment, stibnite, molybdenite, calvarite, syivanite, galanite, ohalcopyrite, chalcocite, bornite, frelbergite, cuperite, malachlte, azurite, chrysocolla, cubanite, hematite, limonite, and steatite.

Stone : Limestone, granite, marble, serpentine, sllica.

Coal, bituminous. clay and cement Clays: Kaoln, fre clay Manufactured prodincts. etc. : Coke, delft ware, terra cotta, fre and common brlck.

Snnset Copper Min. Co., Ererett Washington. Copper ores.

U. S. Marble Co., Spokane. slate. Wrshington Briek, rime and Mfg. Co., Spokane. Firc brick and terra cotta. 


\section{Graphie Arts Division.}

"ORLLERY" HND "WORKSHOP" BUILDINGS.

Thomas M. Moore, Supt. Riehmond C. Hill, Hsst. Supt.

\section{NATURE OF EXHIBITS.}

Paper, Illustrations, Inks, Printing, Engraving, Lithographing, Etching, Bookbinding, and Machinery in use therefor.

\section{EXHIBITORS.}

\section{GALLERY.}

Albertyne Co., Brooklyn. N. Y. Photogravures.

Amerienu Thxec Color Co.. Ohicago. 111. Specimens of color printing.

Appleton \& Co., D., 72 Fifth Ave., New York, N.'Y. Books, lliustratlons.

Brovn Paper Co., L. L., Adams, Mass. Paper.

Bnfialo Printing Ink Works, Butfalo, N. Y. Inks.

Bushnell, Alrah, Philadelphin, Pa. Copying machine.

Central Screen Plate Workn, Niagara Falls. Screen plates for paper making.

Century Co., The, New York City, Publlcations, engravings, etc. Chicago Colortype Co., Chicago, I1.
Color printing.

Courier Co.. Rnfialo, N. Y. Posters, lithographs, etc.

Crane Bros., Westfeli, Nass. Ledger and linen papers. Crane's "Gold Medal", ledger papers. Crane's "Japanese Linen" papers. Crane's "Warranted All Iinen" papers. Are unequalled for coumerclal use.
Donbleday, Page o Co., Ner York, N. Y. Magazine, books, illustrations.

Dow Composing Machine Co., Ner York. Type-settlng machlnes, etc. The machines of this company set, dlstrlbute and justify movable printers' type at the hlghest posslble speed. Best printing efiects at minimum cost.

Caton GIover Co., New York, N. $Y$. Engraving machlnes.

We make machlnes for any kind of engraving. Tell us your requilrements and get the benefit of our long experience in this special field.

Esleeck Paper Co., Turner. Falls, Mass. Papers.

Forman. Bassett \& Hatch, Cleveland, Ohio. Boobbindlng.

Francis. A. F., Cheveland, ohio. Engraving machines.

Funk \& Wngnnils, New York, $N$. X. Books, illustrations.

Craphic Arta Co.. Philndelphin, Pa. Etching machine.

IIall, Geo. P. S Son, New Fork, N. Y. Photographs.

Mansaner \& Son, G. M.. Buffalo, N. Y. Color and other printlng.

Iroen \& Co., A., Baltimore, MI. Maps, lithographiug. 
International Paper Co., New lork City I'aper. Products: Prist, Pavilion $3: 2 \times 20$ feet, laneous patructed of rolis of paper. For exhibit lllustrating process of nauufacture, see exhibit of United States Patent othce in Goverument Bullding.

Korn, Wm., New York City Crnyons.

Lairi \& Lee, Chicago, II. Publications.

Leslie's Pablishing Co., New York clty. Magazine, engravings.

levy, Max, Plilindelphia, Pa. locke, w. O., Cincinnnt, Ohio. Dog pictures.

Madonald, Jnmes, New York City. Bookbinding.

Yann Co., Whlliam, Philadelphia, Pa. Blank books and bookbinding.

Manufacturers of blank books, copying books aud paper; stationers, printers and lithographers. Offices and salesrooms, 529 Market St., Philadelphia, Pa.: 60 Maiden Lane, New York, N. Y. Factory, 21 to 27 North Fifth St., Philadelphia, Pa. Paper mllis, Lambertvilie, N.J.

Hathews Co., The J. N., Bnfralo, S. Y. Specimens of printing and engraving.

"The Complete Press" comprises the Buffalo Lxpress and the MatthewsNortlirup Printing Works, wlth offces and studio in Madison Square Garden Tower, New York. Its fame is international.

McClnre, Phillips \& Co., New York. Jagazine, illustrations.

Merrymonnt Press (D. B. Uruke), Boston, Mass. Printlug.

MittInengne Paper Co., Mitineague, Mass. Paper and statlonery, etc.

National Magazine, Boston, Mass. IIagaziue, illustrations.

New York Consolidated Card Co., The, New York, N. Y. Playing cards. New York Portrait Co., Sigmund Tenner, New York City.

Ningara Paper Co., Lockport, N. Y. Colored cover papers.

Norwood Press, Norwood, Mass. Book-making.

Dsborne Co., W. F., New Ynrk, N. Y. Reproduction of paintings, drawings, etc.

Parsons Bros., New rork City. - Export papers.
Parsons Paver Co., Holyoke, Mass. l'aper, ligh grade.

Perry Pictnres Co., Malden, Maxs. liducational papers.

Pennypncker, M. W. ct C., Asbury Park, N. J. Printing, publications.

Prat, Minnie Soplia, Now York. Bookbinding.

Ringler \& Co., H. A., New York City. Electrotyping.

Schlehr, Jolun IV., Buffalo, N. Y. Metal engraving.

Success Publishing Co., New York City. Magazine, illustrations.

Swift \& Co., A. L., Chicago, III. Art supplements.

The Guiding Star Pulilshing House, Chicago, Ill, Publications.

Toot \& Co.. S. C., Memphis, Tenn. Bookbinding.

United States Geological Snrvey, Washington, D. C. Map making.

United States Lithogrnph Co.. Cincinnati, Ohio. Lithographs, posters.

United States Pinging Carl Co., The, Cincinnati, Ohio. Playing cards.

United States Printing Co., The, Brooklyn, N. $Y$. Posters and specimens of printing.

Western Bank Note Co., Chicago, IIl. Engraving on metal.

Weston Co., Byron, Dalton, Masa. Ledger papers.

\section{WORKSHOP.}

American Embosaing Co., Bnfialo, N. Y. Embossing machine.

Anthony \& Co., E. \& H. T., New York, N. Y. Cameras and photographic apparatus.

Bnbcock Printing Preas Co., New London, Conn. Printing presses.

Bogue, C. J., Ner York. PhotoEngraving lamp.

Boston Printing Preas Co.s Printlng presses.

Bufialo Envelone Co., Bufralo, $N$. Y. Envelope machine.

Courier Co., Buffalo, N. Y. Composition rollers for printers.

Dexter Folder Co., Pearl niver, N. $Y$. Folding machines.

Dow Composing Machine Co., New York. Type-setting machine.

Eagle Ink Co., New York. Printing inks. 
Electric City Engraving Co., Buffalo, N. Y. Proofs of photo-engravings, photo-engraving processes.

Ermold, E., New York. Envelope-, making machlne.

Hempel \& Dingens, Bufralo, N. $Y$. Printers' quoins.

Hobbs Mfg. Co., Worcester, Masb. Invelope-making machine.

Hoe d Co.. R., New Yorlk, N. $Y$. Electrotyping machlnery, etc.

Joneg Co., The John M., Primyra, N. Y. Printers' machinery.

Kelsey Press Co., The, Mcriden, Conn. Printing presses.

Mctaughlin, S., Los Angeles, Cal. Printing frames for photo-engrapers.

Mehle Printing Press Mfg. Co., Chlcago, ill. Printing presses.
Morrison Co., The J. L., New York,
N. Y. Whe stitch Niagara Envelopo

Envelope making.

Oswego Machine Works, Oswego, N. Y. Cutting machines.

Rouse \& Co., H. B., Chiengo, III. Printers' tools.

Thompson Press Co., Johu, New York, N. Y. Printing and embossing
presses.

Tympalyn Co., The, Boston, Masy. Printers' make-ready.

Unitype Co.. New York City. Trpesetting machines.

Vin Allen \& Boughton. Huber Press. Wesel Mff. Co., F., New York. Patent
grooved biock. 
The Pan-American Official Catalogue and Guide.

$\mathbf{r} \mathbf{k}$

F.

ordnance

\title{
Division Buildings.
}

\author{
Thomas M. Moore, Supt.
}

Lieut. Godfrey L. Carden, R. C. S., in eharge.

\section{NATURE OF EXHIBITS.}

\section{Artillery, Small Arms, Ammunition,}

Vehicles, Clothing, Commissary Stores and Equipment, Ship Models, Boats, Relics, Statistics, etc.

\section{EXHIBITORS.}

merienn Bridge Co. of New York, N. Y. Structural steel and englneering equipments.

Amertcan Orduance Co., Bridgeport, Conn. Artillery, coast, fleld and naval guns.

American Ship Windinua Co., Provldence, R. I., U. S. A. Established 185\%. Manufacturers of "Provfdence" Windlasses, capstans and wlnches; Shaw \& Splegle patent automatlc steam towing machlnes; automatlc steam rlding windiasses for Ught-shlps. Stockless anchors; whare props; barrlng engines; rudder supporters, rubber hawse. plpe stoppers chain stoppers, etc.

Americnn Sourenir Co., City Banj. Bldg., Buffalo, N. Y. Concessionalres. Blocher Shoe Mfg. Co. Army shoes, lunting boots.

Buffilo Concession Co., Gencesslonarles.

"Bazacott" Militnry and General Camp Equipment, Chicago, Iil. "Complete Model Outfit" showing U. S. Government Standard camp and field equippage in all ines-Contractors to the U. S. and forelgn governments, Natlonal Guard, sporting, hunting clubs, etc., etc.

champion Rivet Co., Clerelana, Ohlo. Vletor boller rifets.

Catarnet Tool \& Cptical Co., 357 7th St, Buffalo, N. Y. Telescoplc sights.
Chicngo Puenmatic Tool Co.q Monadnock Bidg., Chlcago, lll. Ship construction tools.

Colt's Patent Fire Arms Co., Hartford, Conn. Machine guns, fire arms.

continental Iron Works. Brooklyn, N. Y. Submarlue mines, combustion chambers and corrugated furnaces.

Corson, John W., Hospital Tentw. Driggs-Senbury Gun \& Ammunition Co., 43 Cedar St., New York Clty. Artillery.

Ferracute Machine Co., Bridgeton, N.J. Cartridge machinery, cartridges.

Firth-Stirling Steel Co.,Pittsburg, $\mathrm{Pa}$. Armor plercing projectlle and tool steel.

Fulton-Walker Co., 20th \& rilbert Sts., Phliadelphla, Pa. Invalid carrlages.

Germnn-American Provision Co., Unfon Stock Yards, Chicago. Commissary goods.

Exhibit of Circle " $E$ " Bive Ribbon Brand canned meats for armies and navles and government supplies.

Gruson Tron Works, 31 Vassau St., New York City. Coast defense turret.

Gruson Iron Works, Worka at Eddystone, Pa., near Phliadeiphia. Manufacturers of Gruson Turrets for coust defense. Also Chilied Rolls, Rolling mill plant and chilled and unchilled castings of all descriptlons, 
Helnz Co., H. J., Pittalurg, Pa. Commissary goods.

Hollar Lock \& Guaranty Co., including exhibits from the Betblehem and Carnegle Steel Companles. Armored vaults.

re. Walter, 327 Deinware Ave., Butfalo, N. Y. Water-tlght bulk-head doors.

Lefever Arms Co., Syrnense. $N$. $Y$. Fire arms.

Lexley-Trinkle Co. Cements.

Libbey, MoNeil d Libbey, Union Stock Yards, Chlcago, Ill. Commlssary goods.

Lidferwood Mfg. Co., 96 Liberty St., New York City. Ammunition holsts, model coalling shlp at sea.

Michigan Yacht \& Power Co., Detrolt, Mlch. Armed launches.

Mondragon, F., Lt. Col., Mexican Army. Fuses, smokeless powder.

Ningara Enyelope Manufactory, Concesslonalre.

Pan-American Hadge \& Souvenir Co., Buffalo, N. Y. Concesslonalres.

Pencoya Steel Co., Pencoyal, Pa. Structural steel.

Perkina-Campbell Co., 622 Broadway, CInclnnatI, Oblo. Cavalry and artlliery equipments.

Peterg Cartridge Co., The, Cincinnali. Ohio.

Manufacturers of ammunition for rlfle, revolver, plstol and gun. Peters cartrldges have excelled in every IIne of shooting and hold the shootlng records of the world.

Reever \& Son, Panl S., 1416 Catharlue St., Phlladelphla, Pa. Marlne equlpments. Torpedo spoon ejector, artillery castings. Hemington Arms Co., Ilion, N. Y.
Manufacturers of the celebrated Rem.
Ington slagle shot and Reming magazlne milltary ritles: alsoton-Lee and hanmerless double also hammer shot guns, sportlng and and single and plstols, world-renowned rifes curacy and durabllity.

Ritchie \& Son, E. S., Brookline, struments. Snvage Arms Co., Utica, v. Y.
Fire arms.

See, Hornce, 1 Brondway. New York Clty. Marlne models. Smith $\underset{\text { Mass. Fire arms. }}{\mathcal{E}}$ Wesson, Springfleld,

Studebalier Bros. Mrg. Cı.. South Bend, Indiana, Quartermaster's wag. ons and ambulances.

Swift de., Union Stock Yards, Chicago, Ill. Commissary goods.

rnylor Iron d Steel Co., High. bridge, N. J. Projectlles.

Timkin Roller Benring Axle Co. The, St. Louls, Mo. Roller bearlng axles.

Truax (Chns.), Green \& Co., 42 Wabash Are., Chlcago, Ill. Surglcal
equlpments.

Union Akron Cement Co., Baffalo, N. Y. Cements.

Union Metalle Cartridge Co, Bridgeport, Conn. Ammunitlon.

U. S. Projectile Co., Ist A ve. and $53 d$ St., Brooklyn, N. Y. Projectiles.

Washburn-Crosby Co., 64t Prudential Bldg., Buffalo, N. Y. Com. mIssary goods.

Wilson, J. G., OIean, N. Y. Shutters.

Winchester Repenting Arma Co. New Hayen, Conn. Flre arms and ammunltion. 


\section{Ethnology Building.}

Dr. A. L. Benediet, Supt.

\section{NATURE OF EXHIBITS.}

Archæologic Material, Pottery, Books, Paintings,

Casts, Sculptures, Busts, Indian Relics,

Articles of Dress, Stuffed Indigenous Birds, Animals, etc.

EXHIBITORS.

ukinson, George F., Portage le Pralrie, Manltoba. Indigenous stuffed lirds and animals of impottance to the aborigines. Balcony south.

genedlet, Dr. A. I.., Bufinlo, N. Y. Collection showing discase, Injurles and anomalies of prehistoric bones. Balcony, west.

Relles of transition perlod from Seneca village sites. Halcony, southwest. Common types of stoue implements. Balcony, east.

Double grave near Rochester. Balcony, north east.

Pan-Amerlcan Mound Exploration. Ground floor, northwest.

Reproductlon of vlllage site on Lake Erle.

Benham, J. W., Phonix, Arizoma. Modern Indlan baskets and pottery. Balcony, west.

Blgelow, Otis M., Raldwinswile, N. Y. Centrai N. Y. collectlon from the watershels of Seneca, Oncida and oswego Rivel's showing stone, bone, and copper inplcments, Balcony, north and west.

Brifalo Historical Socicty, Buffalo, N. $Y$. Indian canoe. Balcony, sest.

Bufialo Society of Naturni Selences, Bufialo, N. $\mathbf{Y}$. Chirigui pottery, western net and uasket work, Chiriqui idols and celts. Balcony, north.

cole, Miner T. Pnlmyrn, Mieh. Cache of 800 arrow-polats found in Míchigan. Balcony, east.

Crais. Mnrthn, Torouto, Ont. Speclal feature map of Province of Quebec. Balcony, south.
Dudiey, Mrk. Frank A., Niagnua Falls, N. Y., arrow-polnts, sperr points and drills from Oregon. Balcouy, east.

Sasou, Obed, Sinclairvile, N. $Y$. Archaeologle inaps of Chautauqua $C$. Balcony, north.

Eduardo, Juan. Pernvinn Carpet, east balcony. Peruvlan mummy ualn * entrauce.

Field Columbian Musemm. (Pros. George H. Dursey), Clicugo, Ill. Ancient quarrying and manufacture of flint imple. ments. Balcony, east.

French Colonies. Gronnd foor

Freemnn, Mrs. Maude Deane, Blood reserve, Alberta. Modern Indian relles.

Frost, MrA. Clinrles Hublotra, Buffalo, N. Y. Modern Indlan basket work. Balcons, west.

Gould, Prof. Charlen Newton, Norman, Oklalioma. Anclent quarry refuse from Kansas. Baicony, east.

Hnles, Henry, Ridgewood, N. J. Indlan relles of stone age, bone Implements, Clia Dweller pottery. Balcony, west.

Harris, Mrs. Jnila Ha; Rachenter, N. Y. Prehistoric stone implements. Small room off balcony, north. Hownrd Nemorial Library (Wil-
llam Beer), New Orleans, La. Old maps and books. Balcony, north.

Lake, George H., Lewiston, Iaho. Arrow. polnts. Balcony, east. 
Los Angeles Chamber of Commerce, Los Angeles, Cal. Indian relIcs, pottery, basliets. ctc., photographs. Small room off balcony, north.

Morgnn, R. H., Bufinlo, N. Y. Hitcheocl, C. H., Hanover, N. H. Map of Economic G:ology ot rborigines of the U. S. Balcony, east.

Monlthrop, Col. S. F.., Rochester, N. Y. Modern aud prehistorlc implements. Articles of Indian dress and ornament. Narajo, Zunl and Apache pottery. Balcony, north.

Rellef map of Monroe Co. Balcony, east.

Nelson, George. Arrow points. Gladstone, Ohio. Balcony, east.

N. Y. State Museum (Dr. F. J. H. Merrill), Albauy, N. Y. Indian masks of modern Iroquois. Balcony, west.

NuttnI, Mrs. Zelin, Cambridge. Mass, Fac-simile of Hlspano-Mexlcan MSS. book of the $16 \mathrm{th}$ century.

Fac-simlle of ancient Mexican codex belng a blstory only partly deciphered of the reign of Mcontezuma. Balcony, south.

ontario Erincation Denarment (Darld Boylc), Toronto, Ont. Prehistoric implements of stone, bone and copper. Huron-Iroquois slulls. Archaeologic map of Ontario. Model of aboriglnal earth-work. Balcony, south.

ohio State Archnaological nul Historical Society (Prof. W. C. Mills), Columbus, Ohio. Implements, ornaments, food and mode of burial of the Mound Builders of Ohlo. Maps. Ground floor, west.

Pan-American Exposition nud Hon. W. I. Buchanan. Samoan collection including implements of warfare and the manufacture of Saplo from fibre which is worked into ar. tlcles of dress. Ground floor, north.

Pan-American Exposition. Seren plaques, reproducing conventional deslgns from Cliff Dweller pottery. Mlss Clalre Shuttleworth, artist. Around balcony rail.

Three models of Mound Bullder earthworks, Miss I. S. Chandler, artlst.

One large map showlng llnguistic stóclss of America. Hangs from balcony rall, east.

One map of Nlagara frontler showing sltes of aboriginal occupancy.

One dug-out canoe. Balcony. west. Model of Indlan vllage. Balcony, Landscape gardening effects-near Six Natlons exhlbit.

Ringed tumulus.

Serpent Mound.

Fagle Mound,
Pealoody Institute,

Mass. Cast of monolith Cambrilge,

Copan. Ground floor, east.

Quick, Mrs. Marinet.

Falls, N. Y. Wilver ornamet, Ningara Indian grave in Obio. Balconts liom

Seligm nu, Arthnr. Balcony, west. Mexlco. Collection Santa Fe, Ser modern Navajo blankets antique and wall frieze of balcony. Around the

Silver, D. M., Bufinio, N. Y. Pre. historle lmplements and ornaments of bone and stone. Balcong, west.

Smith, Dr. Lee F., Brifa! o, Y. Y. kansas. Balcony, west.

Sinith, George A., Og

Prehistoric Iudlan relics mound at Oakficld. Small model of balcony, north.

Snyder, Mrs. R. WV., Canandaigua, Balcony, west.

Starr, Prof. Frederiek, University of Chlcago, Chicago, Ill. 18 portrait busts of Mexlcan Indians. Garments. Musical lustruments (Aztec) represent. Ing life of modern Mexlcan indians Votlve offerings dredged from Lake Chapala. Casts of carvings on stone. Oaxaca. Balcony, south.

Ste. Croix de la Ronciere of Guad. aloupe. Inscribed stone, stone hoes, celts and pestles. Ground floor, east.

qhom pson, A. W., Orangeville, Ohlo. Prehistorle implements, Ohlo. Baicony, north and west.

Twitchell, Dr. H. W., Hamilton, Ohlo. Mound Bullder and Indlan stone age relies from Oblo. Balcony, north and west.

University of Penmaylvania (Prof. Stewart Culln), Pbiladelphla, Pa. In. dlan games, weapons and ornaments Photographs. Ground floor, west and east balcony.

U. S. National Mufeum, Washing. ton, D. C. Munlz collection of 19 pre. hlstoric Peruvlan skulls, trephined. Balcony, west.

Plaster casts of stone age relics. Bal. cony, east.

Ward's Natural Seience Establish. ment, Rochester, N. Y. Cliff Dweller Models. Raclal types shown in busts. Case of skulls showing racial types. Alaskan Implements and ornaments. Balcony, north.

Washington. Stuffed biris. animals and fish lllustratlng food suppls of abor gines. Ground fioor, north. Methods of aborlginal hunting, fishing,
etc. 
rende, Dr. H. S., Tonawanda, N. Y. Archaeologic inaterial mainly from Grand Island, N. Y. Balcony, north.

\section{MEXICO.}

\section{Ground Floor, South.}

blake, W. W., Mexico. Old origlnal pieces in gold, silver, stone aud clay.

Garcia Cnbas, Antonio. Mexico. D-F. Map of the Valley and City of Vexico in the midale of the XVI century.

Ilap of the lands discovered and conquered in the Republic by the Spaniards during the $X V I$ Centurs.

Penafiel. Dr. Antonio. Mexico; D. F. Historical book "Teotihuacan." Tarasco ianguage.

Uexican language. Rincon.

Zapoteca grammar.

Huasteca grammar.

Alphabets of the Aztec language.

In astronomic and conic stone.

A calendar's relief.

Aztec date.

Cosmogouical rellef.

Adate of the Aztec calcndar.

لyayas' reliets :

Cosmogonic reliefs of a cubic stone found iu the basement of the "Centro Mercantil" iu the corver of Malu Squarc. Rcliefs of a stone recently found in the drainage excavations in Escalerlllas St., City of Mexico.

Rellefs of a large monolith also found in the basement of "Centro Mercantil" in Main Square.

Decorative reliefs of a large stone vase of the National Museum.

Rellef of a typical Aztec Goddess.

Cuauxicall,, cylindrical stone of the

National Museum.

Conic astronomical stone.

Date of the "Teponaztie Mirteco" modeled in stafi.

Reliefs of a cosmogonic stone.

Rellef of a stone called "Nahuiolil."

Relief of a calendar.

Relief of a mythological tecpatl.

Decorative reliefs of a large stone vase of the National Museum.

Aztec date.

Cosmogonic rellef.

date from Aztec calendar.

Hieroglyphic of the Goddess Chicomecuatl.

Relief of another form of Nahuiolli.

Reliefs of an Ocelotl and Cuanhtil.

irsthological Aztec relicf.

Date of thc foundation of the "Tem. plo Masor."

Relicf of the Tzontemoc.
Relief found in the monolith of the Goddess Miquiztli, in the excavations at Liscalerillas St., City of Mcxico.

Aztec Goddess with womanly dress.

Datc of a calcndar on a cylindrlcal stone.

Relief of a stone of Palenque found lately. It contains calcareous hleroglyphics.

Sandoval Rosendo, Protersor, Mexico, D. F.

One reproduction in plaster of a vase of obsidian stone.

Five old original pieces in ciay.

Secretaria de Fomento, Coloniza. cion e Industria. Mexico. D. F.

Decoratlve models of the ruins of Teotibuacan.

'I'wenty-fire reproductions of decorated vases.

Four Aztec decorated plates.

Two water colors of the vases found on the Escalerillas St.

Three water colors Aztcc pictures.

Two water colors of the Teotihuacan frescoes.

Three Teponaxtles.

Nineteen panoplies and trophies.

Codice Borbonico.

Codice Fernandez Leal.

Codlce Mizteco.

Geographlcal names of Mexico.

Fabulas de. Esopo in Mexion language.

History of the Province of Santiago de Mexico.

History of the Province of Santo Domingo.

Congress of Americanistas.

Árqueological Catalogue.

A carpet with Arqueological phototypes.

Monuments of the old Mexican Art. Antiquaries of the Colombian Commig. sion.

Mexican Building.

Secretarin de Fomento, Colonisacion e Industria. Collection of cotton, clay and woolen articles of ancient and modern Indian art.

Two Cinerary dccorated vases.

Three reproductions of cinerary urns.

Two large funeral vases found in Discalerllas St.

\section{Archaeologic Books in West Balcony Library.}

Aboriginal Occupation of $N$. $T$. Willam T. Beauchamp.

Amerlean Philosophical Society exhibit the following: Fundamental Laws and Regulations, Charter and Laws (1898), List of Members (January, 1900), Slgner's of Membership Roll (June 10, 1896). 
Antinuties of Tenncssee. Gen. Gates P. Thurston.

Archaeological Report. Ontario, 1890-1898 ('2 Vois.)-1899 (3 Vois.).

Burenn of Ethnology Reports-20 Vois. from 1879 to 1897.

Catnlogne Prelistorie Works East of Rocky Mountains. O. Thomas.

Centenuial Celebration of $N$. $Y$. State.

Documentnry Mistory of New York.

Estate of Dr. Daniel G. Brinton exhlbit the following: The Fioridian Penlusula, Annais of the Cakehiqueis, the Reiigious Sentiment, Anelent Nahuati Poetry, American Hero Myths, Rig Veda or Saered Chants of the Ancient Mexicans, the Iroquois Book of Rites, Comedy Ballet of Gueguence, Essays of an Amerleanist, a Migration Legend of the Creels, the American Race, the Lenape and their Legends, Studies in S. Ameriean Languages, Nagualism, Primer of Mayan Hieroglypinics, Liuguistic Cartography of Chaco Iregion.

Ft. Ancient, Ohio. W. K. MooreLead.

Guatemala. Bnrcan of American Republics.

Harriot's Description of tire Iudians of Virginia. By Debry, 1590.

Hintorie Blenuerhassett Island Ilome. Alvan F. Gibbons.

IIstory of Florida from 1512 to 1722-Madrid, 1723. Howard Memorial Library, New Orieans, La.

Hownad Memoriai Library, New Orieans, La. Exhibit the foilowing: Irarriot's description of the Indians of Virginia by Derby 1590 . History of Florida from 1512-1522, Madrid, 1723.

International Folk-Iore Assoc. exhibit the foilowing: Tales from the Totems of the Hidery, eoileeted by Deans; History of the Devil and the Idea of Erii, Paui Carus, Ph. D.; Int. Foik-Lore Congress of Worid's Colnmbian Exposition. Editors, Heien Wheeler Bassett and Frederiek Starr.

Jesuit Relntions and Allica Docnments. Washington Ploneer Assoc., R. G. Thwaites, editor. Exhibited by Burrows Bros., Cleveland, 0 .

Mnn nud the Glacial Period. Prof. G. Frederick Wright, Oberlin, $O$.

ilonosraplia Higtoria Americana Onanne, Lima, Peru.

onio Archaeologicni and IIstorieal Soeiety Pubilcations -8 Vols.

Prehistoric Implcments. W. K. Moorehead.
Prinitive Man in ohio. W. K.
Moorehead.

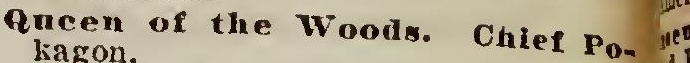

reports of Explorntion in Alanka. Edwin F. Glenn, W. R. Aber-
crombie.

Smithsonian Reports-20 Vols. from 1881 to 1897 .

\section{Pamphlots.} Address by Frederick Wnra Pat-
nam, Peabody Museum.

American Anticuarian. stephen D. Peet, editor.

An Ancient Qunry in Indian Territory, W. H. Hoimes. Ancient American Cnlenar
Stone. Mrs. Zelia Nuttail.

Antimurian Socicty of Montreal. Wxhibition of oid MisS., etc., St.
Iary's College.

Archneology of New England. Prof. G. H. Perkins.

Catalogne of Canndinn l'ortrnita and other objects relating to Canadian
Archaeoiogy.

Cntalogue of the Chatean Kamezay Museum.

Cataloguc of rore and choice books relating to Amerlea.

Catalogue of Relief Maps, Model of Cilif IIouses, Mounds, ete. Ward's Naturai Scienee Estabilishment.

Caverns of Copan, Honduras1896-97. By G. B. Gordon.

Contribntions from the $U$. S. National IIerbarium. I. N. Rose.

Contributions from the U. S. Nationai Herbarium. Frederick V. Coniiie.

Distribution of Stone Implements. W. H. Hoimes.

Flaked Stone Implements. W. I. Holunes.

Fundamental Princivien of old and New Worid Civilization. Zella Nuttall.

Guide to Penbody University, the Peabody Musenm of American Árchaeology aud Ethnology, Cambridge.

Hochclagans and Mohavks. W. D. Lightall.

Le Ferou $n$ I'exposition de 1900. Memories of the American Mnseum of Natural History. Iarian J. Smith.

Honnmental Recorais, Rev luenry Mason Baum. 
The Pan-American Official Catalogue and Guide. K. and Exploration for the Pnnenm Associntions of the UniJingdom, Harlan J. Smlth. tonal Academy of Sclences. ol, 3, Vol. 6.

the Indinn Mnsic. Allce $C$. thether.

phlets on the Nampa Imnge. W. Frederick Wright, Oberlin, $O$.

mody Musenm Reportm-Vols. $2,3,1868-75-76-79-80-86$.

hody Munenm Reports-21nt, ind 23d and 24th.

it Structures in Nomman's creek, Delatware. By Hillborne T. cosson, A. AI.

rehlutoric Bnrial Place in Jalise, Chas. C. Willoughby, Perbody yoseum.

phistorte Rulns of Copan, Hondutas, 1891-05.

port of Field Work. Pror. WilHam C. Mills.

eport of Field work. W. K. llorehead.

istearches in the Ulon Valley, Honduras.

yndard or Hend Dress. Zelin Vuttall.

tone Monnmentw in $N$. W. Yowa und $\mathrm{S}$. W. Minnesota.

fone Monuments in Sonthern Dasota.

tory of Niagara. C. H. Hitchcock.

Irmbolimm in Ancient Americnn Art. F. W. Putnam \& C. C. Wllloughby.

the Atlntl or Spenr Thrower of the Anclent Mexicans, Peabody Museum. Zella Nuttall.

The Karankarra Indian. Albert S. Gatschel.

the La PInta Musenm. R. Lydekker.

Trangactions of the onetda IHstorleal soclety, No. 8 .

\section{ART GALLERY.}

The following by Erle Pape, Artist, Boston, Mass.:

1-From the Azoteas Cuauhtemotzin saw them enter the city. Monotone black and white oll color.

2-Cunubtemotzln, the fortunate hero, standing so calmily before them. Black and whlte. oll color.
3-Not without a certaln plcturesqueness as they crossed the torrent. Charcoal drawing.

4-The Indian looked gloomlly lnto the water. Gouache and monotone color drawing.

5-At a palace near the edge of the clty the escort halted. Grouache and monotone color drawlng.

6-The Princess Tula and Nenetzin with the scroll. Pastel.

7-Alvarado and the page. "Over the brldges the horsemen galloped." Gouache and monotone color draw. Ing.

8-A mist, not of the lake, rose and hid them from Cuaubtemotzin's view. Charcoal drawlng.

9-Upon the adrance of the captalns Io stepped in front of the king. Gouache drawling.

10-Tula gare Cuauhtemotzin the signal by remoring the scart. Gouache aud monotone color drawing.

11-A Spanlsh messenger, "Staggerlng as he ran, and shoutlng." Wash drawing.

12-Each met the other's gaze. Monotlat black and white oll color.

13-Craftsmen entertalned and irlghtened each other with storles. Charcoal drawing.

14-Moctezuma (struck by a stone) fell, corered by the spanlsh shlelds. Gouache and monotint color drawlng.

15-On the Temple Tower. "For lore of woman, stay!" shouted the priest. Gouache drawlng.

16- "In a hammock that swung to and fro." Monotone black and white oll color.

17-Cortes drew rein only at the foot of the barricade. Gouache and monotlnt color drawing.

18- "Beware, O klng. the ears of the God are open." Joctezuma before the altar and statue of the great God of War. Pastel In three colors.

19-The Child of the Temple. Gouache and monotlnt color drawing.

20-[tz]11 staggered under the tremendous blow. Wash drawing.

21-Daughter of the lake, Falr Tenochtitlan, the clty of temples and of the Aztecs. Oll color.

22-"Bring thy bones here, Father," sald Cortes. Gouache drawling.

23-Moctezuma studied the Cacique's face. Gouache and monotint color drawing. 
24-Like the night, the lake was caim. Pen and wash drawing.

25-The white wings on her breast. Gouache and monotint color drawing.

26-The tambour in the Temple soundcd the signal. Pencil drawing.

27-"Dld you Imagine she would learn to love him?" Gouache and monotint color drawing.

28- "A clang of sandaled feet." Biack and white oll color.

29-Indian slave of the Princess Nenetzin. Gouache drawing.

30- "Your love was dearer to me than the crown." On the Royal floating garden. Gouache and monotint color drawing.

31-Hugging their arms on their treasure, marched in dogged silence. Gouache drawing.

32-Tula drew the curtaln quickly. Gouache and sepia drawing.

33-The Spaniards entering Tenochtitlan by the great causeway. "Out of the way, dog!" shouted Sandoval. Gouache and monotint color drawing.

34-He ralsed her gentiy and carrled her through the entrance. Gouache and monotint color drawing.

35-Embossed book corer for the "Edition de Luxe" of The Fair God, by Lew Wallace, illustrated and decorated by Eric Pape.

36-Aztec atlatls and arrow. The atlatl was used for throwlng arrows. Pen drawing.

37-Stone Mask from Copan. Pen drawIng.

38-Statue in stone of Xochiquetzal, from Iztapan. Pen drawing.

39-Young Indlan girl from Coatepec, Mexico. Aztec manner of wearing the poppy. Pen drawing.

40-A vlew of the fresh waters of lake Chaico. Pen drawing.

41-Design after the famous bas-reller from the ruins of Palenque, Yucatan. Pen drawing.

42-An Aztec bridge and hut. Pen drawlng.

43-A flower much used by the Aztecs for decoration. Pen drawing.

44-Caiabash enclosed within a rope sack; a grass mat (rolled), and water gourd. Pen drawing.

45-Aztec stone necklace with head cut in fine hard stone. Pen drawing.

46-Hualpa, the Tehuacan-the friend of Cuauhtemotzin. Pen drawing.
47-Aztec warrior drawing the bow.
Pen drawing.

48-Stone mask from Copan. Pen
drawing.

49-The God of Hell. A monolith in the National Museum, Mexlco City. The bottom of a large urn, into whlch were thrown the hearts of victims of the sacrificlal stone. Pen drawing.

50-Polychrome rase from the Valley of Mexico. Pen drawing.

51-Stone urn used in temples for the sacrificlal fires before the altars. From the Valley of Mexico. Pen drawing.

52-Terra-cotta vase of fine workman. shlp, now in the National Mexican Museum. Pen drawlng.

53-The fires of the (Teocalii) temples glowing at evening. Pen draving.

54-Spanish knight in armor. Pen drawling.

55-Aztec dancing giri (with wooden drum) decorated with the poppy flower. Pen drawling.

56-Artec with the maquahulti, the deadliest weapon used by the anclent Mexlcans. Pen drawlng.

57-Toitec Water God. Pen drawing.

58-Terra-cotta urn used for sacred fires in the temples of the anclent Mexicans. Pen drawlng.

59-Aztec bas-rellef cut In stone. Pen drawling.

60-Indian belt and pouches. Pen drawing.

61-The Aztec maquiahultt and Toltec battle clubs and spear. Pen draw. lng.

62-Spanish cross-bow with crank, such as was used by the soldiers of Cortes. Pen drawing.

63-Aztec tlute and belt. Pen drawing.

64-Spear decorated with feathers. Pen drawing.

65-Aztec maiden of Moctezuma's household. Pen drawing.

66-Cholullan chlef and bodzguard. Pen drawing.

67-Aztec teocalilor temple. Pen draw. ing.

68-Spanish knlght ready for battle. Pen drawing.

69-Terra-cotta plates from the Valley of Mcxico, the second one with handle, being used in human sacrifice. Pen drawlng.

70-Statue cut in stone, called "The Sad Indlan," now in National Museum, Mexico City. Pen drawing. 
bow, phe datec clieftain's plumes and ornawental statt. Pen drawing.

Pen

In the City. into

e. Pen

Valley

or the

itars.

Pen

man.

lean

ples

ag.

$P_{\text {en }}$

en

be

be

an ancient delty cut in soft white stone. Pen drawing.

flerr of an ancient city In Analuaac before the conquest, showing temples in the distance. Pen drawing. -The great cactus from which the iztec drew pulque, thelr favorite bererage. The step pyramid of Cholulian in the distance. Pen drating.

in Aztec's scribe's outflt. Pen drawing.

- Aztec canoes and dug-outs. Pen drawing.

-Spanlsh breast-plate and helmet, battle-axes and double-handed strord. Pen drawing.

Hlounted Spanish knight, of the time of the Conquest of Mexlco. Pen drawing.

in-Spanish crass-bow, time of the Conquest of Nexico. Pen drawing.

n-Roçal Aztec palace and gardens. Ped drawing.

M-Father Olmedo, one of the priests with Cortes in the Conquest of Mexlco. Pen drawing.

Q -Indlan gIri from Xalapa, Mexico. Pen drawing.

83-A flower much used by the Aztecs for decoration. Pen drawling.

A-Spanish filnt-Iock plstol, embossed shleld, broadsword and battle-axe. Pen drawlng.

80-The Anclent Viga Canal, Mexico. Showing an Aztec in a dug-out. Pen drawing.

86-Mualox, the paba, before the sacred fire lu the Cu of Quetzalcoatl. Pen drawlng.

87-Cuanhtemotzin and Hualpa. Cuauhtematzin Inlerited a great fortune, ducal rank and an estate near Iztapalapan. Pen drawing.

8s-Rulns of an anclent palace. Pen dra wing.

B9-An Indian of Mexlco, with water jugs. Pen drawing.

The following six monotone watercolor palntings illustrate "The Incas," a poem by Telford Groesbeck. Eric Pape, artist.

Bo-"They hear the Thunder's volce, see Lightning dart away

To break the East wind's vase ere the approach of Day;

They see volcanoes punf to raise their plumes stlil higher

Then boldly kiss the cheels of Morn with IIps of fre."
91-"Aellahuasl where

The royal virgins dwell,-perchance embrold'ring there

Sweet dreams of love for him, whilst watching sacred fires."

92- "The twenty eyes of gold with those In Purichau's face,

Gaze down through aisles of priests to where with outstretched hands,

The llving Inca Lord, proud Huayna Ccrpac, stands."

93-"Note these In puna fur,

Their heads within the skulis. How now they growl and purr,

As fellne strides they take round those in slins of deer

All crowned with antlers old, they shout with glee at fear."

94-"The graceful forms, half nude, with lovers interlaced,

The newly-mated souls in tenderness eubraced."

95-The temple of the Sun.

96-The moose hunt. Geo. De Forest Brush, Scarboro, N. J.

97-98-99-100-101-Five color drawings fllustratlng Geo. Bird Grinell's "Chinook Indlans' Folk-Lore," Tale entitled "Punishment of the Stingy." E. W. Deming, 21 W. 24 th St., New York.

102_"Hlawatha's Vislon." J. W. L. For'ster, 24 KIng St., Toronto, Ont.

103-An Indian Funter.

104-Squaw making bark work.

105-Man's head.

106-Boy's head. unt.

Mrs. Ainsile Hime, Deer Park,

107-Modern Indian from Cattaraugus Reservation.

108-Composite type: Indian part negro. Josephine Lewis, Buffalo, N. Y.

109-Indian portrait. Costume of Northwest. Owner, Archaeologlcal Museum of Ontario. T. Mower Martin, artist.

110-Water color portrait of celebrated "Crowfoot." Owner, Archaeolog. ical Museum of Ontario. M. J. Hemsted, artist.

111-Portrait of Indian Woman. Owner, Archaeological Museum of Ontarlo. W. S. Sherwood, artist.

112-Portralt of Pere Marquette, the discoverer of the Mississippl, great missionary among the Indians. This is a copy of the only existing portrait of Marquette, discovered three 


\section{The Pan-American Official Catalogue and Guide.}

years ago in Montreal. Owner, Archaeological Museum of Ontario. Donald G. MeNab, artist.

The following very rare lithographs of Indian life are by Catiln. Owuer, Archaeological Museum of Ontario:

113-Osage warrior, Iroquois chief and Pawnee woman.

114-Indian iacrosse players.

115-Grizzij bear hunt.

116-Sioux Indian perils.

117-Bear dance.

118-Snowshoe dance.

119-A surround-buffalo hunt.

120-Mandau game of the arrow.

121-Sloux lacrosse game.

122-Lassoing the wild horse.

123-Choctaw lacrosse dance.

124a-Buffaio hunt, summer.

$124 \mathrm{~b}-$ Buffaio hunt, winter.

125- "Listening for the war cry." Indian chlef. Miss Imily Pcck, Anderson Bldg., Buffalo.

126-Sunset and Moonrise. The Great Chief or liuling Spirit of the Co. iumbia.

127-Indian saimon fisiling camp on the Columbia River, Oregon.

128-Grey Day, a bit of Indian town, Sitka, Alaska.

129-A general view of Indian town, Sitka, Alaska.

130-Mt. St. Ellas from Yakutat, Alaska. 131-Beginning of the sunset glow, Meltakahtia, Alaska.

132-A bit of Indian town, Loring, Alaska.

133-Evening. Alaska and British Columbla Indians camped on a sand pit, near Port Townsend, Washington.

134-Esquimaux tishing and hunting camp, on an isiand near Cook's inlet, Alaska.

134a-Makah Indian Reservation.

134b-Front view of Indian town, Sitka, Alaska.

Artist J. E. Stewart, Chicago, III.:

135-Indian camp near Hop Fleids at Puyallup, Wash. Malte $L$. Stlerngranat, Chicago, III.

The following fifty-ive palntings by J. H. Sharp, 118 East Fourth St., Cincinnati, O.:

\section{CHEYFNNES.} 136-Two Moons, head chlef of the
Cheyennes aud prominent in Custer
battle.

137-Chlef Little TVolf, considered the greatest fighter and general of all
the Indiaus.

138-Little Wolf, nephew of above, and prominent man of the tribe.

139-Little Chlef, a noted fighting chiet
and oldest of the tribe.

140-Elkhorn.

141-Grasshopper.

142-Coyote that Howis.

143-Black Ree.

144-Culef Amerlcan Horse. Prominent chief who has prevented many bat

145-Buil Bear. Southern wise counsel. cated at Carlisie.

146-Rising Fire.

147-Medicine Shell.

\section{SIOUX.}

148-Chler Fiat Iron, raised with, $\varepsilon$ nd great iriend of Sitting Bull, Pro.

149-Chler Fiat Iron, figure smoking.

150-Chlef Rocky Bear. A great war rlor and man of much honor and dignity.

151-Chlef Spotted Iik.

152-Hand, noted scout in battie of Wounded Knee and others.

153-Waiks the Country, smail profle.

154-Walks the Country, full race.

155-Last Woman, typical Sloux squaw.

156-Red Copper, dress decorated with elk teeth and valued at $\$ 400$.

157-Yellow Owi, leader of the Omaha dance; favorite dance of the Sloux.

158-Interior of Crow tepee.

159-Cheyenne tepee camp.

160-Crow tepee camp.

161-Cheyenne tepee camp.

162-Chlet Biue Horse, a big chlef and man of much influence many years ago. (Sloux.)

\section{APACHE.} 163-Oid Apache squaw, over 100 jears
old.

PUEBLOS OF NEW MEXICO.

164-Pushing Bull.

165-John Mrabelle ("John of Taos").

166-Study of Figure.

167-Summer Rain.

168-Standing Deer. 
The Pan-American Official Catalogue and Guide.

2-Soaring Eagie.

v-Corn Star.

1 - Toung Grass.

:-Soaring Eagle, Jr.

i3-Ex-Gorernor of Taos.

it-Pueblo of Taos.

in-Juramata.

if 6 -Pueblo.

ini-Pueblo, Alonzo.

18-Pueblo from Tesuque.

liq-Puebio.

180-Erenlng Chant.

181-Grave in eottonwood tree.

182-Yellow Hawk.

183-Pueblo of New Mexico.

\section{CROWS.}

184-Grave on scaffold.

185-Squaw mourning on grave.

186-0ld grave, Crow Reservation.

187-Crow agenes, police tepee.

188-Flora Hairy Wolf.

180-Takes a Wrinklc, noted Crow orator.

100-Chief Carney, ehief of Big Horn Crows.

101-Crow Medlcine Man.

102-Medlcine Breath.

The foilowing ten paintings of raeial trpes by Hubert. No. 70, Carnegle Hall, New York.:

193-Hawallan fisher boy.

194-Kolmona, Hawailan minstrel.

195-Study of Hawallan fish.
196-Ekekela, Hawallan flower girl.

197-Composite type, sons of mandarins (Chinese).

198-Composite type, woman of higher elass (Chinese).

199-Siour Indian Chlef in buffalo robes.

200-British Guiana Indian.

201-Chlppewa Indlan.

202-Sloux Indian in Tar dress.

Pencil sketch of Indiau girls, Penobscot, Malne :

203-Bazz-Aquah (Golden Rod), full blood type.

201-Faillng Star, one-quarter FrenehCanadian.

205-Wam-ta-Wago (Bright Star), mixcd type.

206-Nee-Bana (Northern Lights). French half-breed.

Artist Franels West, Boston, Mass.

207-Agalnst fate. Chas, 3. Springer, Providence, R. 1 .

208-Ojibaway Indians, Lake Superior.

203-The portage.

210-Sioux camp.

211-Beech trees.

212-Sioux chicf, "Big Bear."

213-Ojibaway belle.

Artist, F. A.Verner, 39 Palace Terrace, Fulham, London, Eng.

Most of these paintings are for sale, to be delivered at close of the Exposition. For particulars inquire at Curator's desk. 
The Pan-American Official Catalogue and Guide.

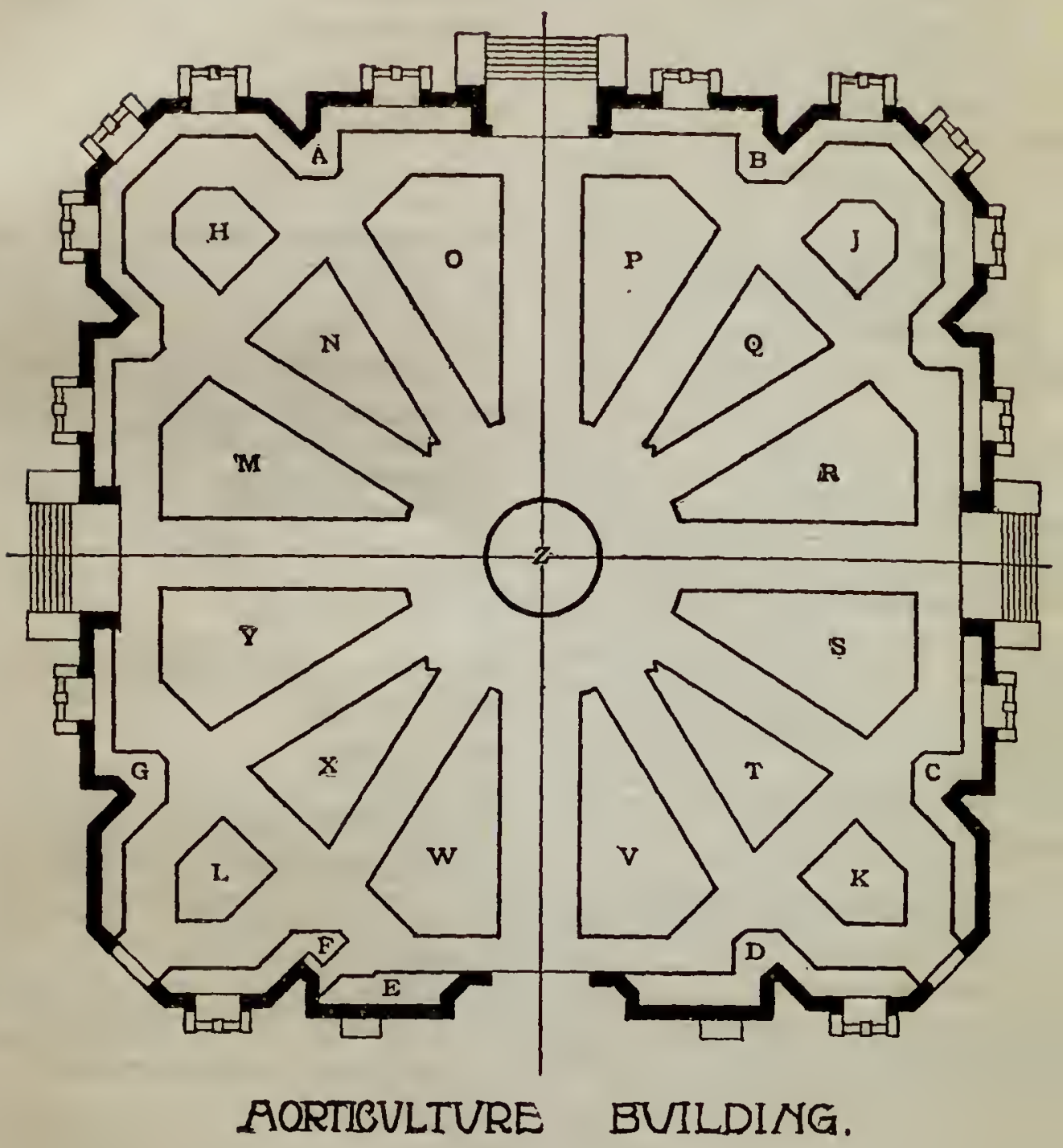


The Pan-American Official Catalogue and Guide.

\section{Horticaltare Bailding.}

Frederie tu. Taylor, Supt.

KEY TO INSTALLATION.

The ground floor plan of this building (see opposite page) is divided into :xtions, which are indicated by the letters $\mathrm{A}$ to $\mathrm{Z}$. Each exhibit is located by referring to the lettered space.

\section{EXHIBITORS.}

Irkanmas-C.

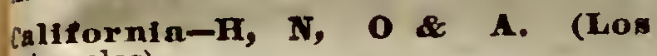
Angeles).

callornia-P, Q, J $\mathbf{B}$ (San Fran(isco).

connecticut-I.

Delaware- $I$.

Florida-Y.

Idaho-R.

Illinois-V.

Indiana-M.

Maine-B.

Michigan-T.

Missonri-R.

Nebraska-D.

New York-W, $\mathbf{x}$ \&

oregon-S.

Virginia-C.

Washington-A.

Wisconsin-S.

American Ginseng Co., Rose Hill, N. $Y$.

Fleischman, Joseph, New York, N. Y. Conservatories.

Hammond. Benjamin, Fishrill-onHudson, N. Y.

Henderson \& Co., Peter, Nev York, N. Y.

Hicks \& Son, Isane, Weatbury Station, N. Y.

Krick, W. C., 1287 Broadway, Brooklyn, N. Y.

Miller, George, Bristol Springix, N. Y.
FOREIGN COUNTRIES EXHIBITS.

Costa Rica-F.

Guntemala-B.

Jamaica-A.

Mexico-Ix, $C$ \& $\mathbf{D}$.

Nicaragua-Y.

Ontario-M.

\section{WINE EXHIBITS.}

Germania Wine Co., Hammondaport, N. Y.-G.

Glenson Frait Juice Co., Westfleld, N. Y.-Y

Hommel, M., Wine Co., Snndurky, Ohlo.-J

Urbana Wine Co., Urbann, $N$. $X$. Wines and brandies. Gold Seal Champagne, made after the French method of fermentation in the bottle. We solicit comparison with anj champagne made.-C.

\section{COLLECTIVE EXHIBITS.}

\section{Located in North Conservatory.}

Balbiani Bros, \& Co., Buenos Ayres, Arg. Rep. Cordials and bitters, Barrh.

Balbiani Bros. \& Co., Buenos Ayres, Arg. Rep. Cordials and bitters, Bitter.

Balbiani Bros. \& Co., Buenon Ayres, Arg. Rep. Cordials and bitters, Fernet.

Balbiani Bros. d Co., Bnenow Ayres, Arg. Rep. Cordlals and bitters, Vermouth. 


\section{The Pan-American Official Catalogue and Guide.}

Cafetal Carlota Coupany, Counselman Bldg., Chlcago. Coffee, green and roasted.

D'Aubigny \& Co., Port au Prince, Haytl. Soap.

Lensner. Romer \& Bassel, Meияrs., care of Bothfeld \& Weygandt, 78-80 Broad St., New York. Cocoa beans.

Molinari, Pio J., Buenon Airew, Argentine Rep. Aperitlno Molinarl, mlneral water.

Palermo, Cerveceria, Buenos Afres, Argentlue Rep. Salvator beer.

Palermo, Cerveceria, Buenow Ayres, Arg. Rep. Vletoria beer.

Price Flavoring Extracts, Chicago, IIl. Vanilla vlues und products.

Rine, A. H., St. Thomas, Dauimh W. I. Bay oll.

Rilse, A. H.. St. Thomas, Daniah W. I. Bay rum.

Hise, A. H., St. Thoman, Danish W. I. Florlda water.

Shepard, Dr. Charlen U., Summervllie, S. C. Tea plants and products.

\section{ILLINOIS.}

\section{Exhibit of Apples.}

Aldrich, H. A., Neoga, III.

Bryant, A., Princeton, IIl.

Bryant, L. R., Princeton, Ill.

Calhoun Co. Hort. Society, Hardln, IIl.

Dumlap, H. M., Savoy, I11.

Iincley, A. A., Du Bois, 111.

Husband, Jas., Leanderville, I11.

Kimery, J. T., Neogga, IIl.

La Rush, S. D., Pekin, 11.

Perrine \& Son, Centralia, 11.

Powers, John, Tiskilwa, Il.

Sonerhil, S. G., Tiskilwa, I1.

stilen, W. J., Sandoval, Ill.

Stone de Son, J. A., Springfield, I1.

Voris, F. D., Neoga, III.

Winn, C. G., Grikgøville, I11.

Young, W. A., Butler, I11.

Zeigler, W. J., Clinton.

\section{CONNECTICUT.}

\section{Strawberries exhibited by}

Eddy, J. C., Simsbury.

Farnham, A., New Haven.
Johnwon, Dr., Mansfeld. Plant, A. E., Branford.

Savage, C. H., Storrs.

Warner, E. C, Fairharen.

\section{Apples exhibited by}

Aborn, W. J., Rockrille. Allen C., Terryville.

Andrews, J. E., New Britaiu.

Conn. Agl. College, Storrs.

Conn. Pomol. Society.

Cook, S. G., Branford.

Fenn, Dennis, Milford.

Griswold, S. A., Went Martford.

Mall, G. D., Wallingrord.

Hough, J. R., Wailingtord.

Manchenter, E., Dristol.

Merriman, S. H., New Britain.

Molumphry, J. T., Berlin.

Roberts, S. W., Middletown.

Stocking, M., Simsbury.

\section{Currants exhibited by}

Conn. Agl. College, Storrs.

Chorries exhibited by

Fish, George, Mansflel.

\section{DELAWARE.}

\section{Exhibit of fruits in season.}

Momley, W. S., Dover, Del.

Myer \& Son, Bridgeville, Del. Slaymaker \& Son, Camien, Dei. Soper, F. M., Magnolia, Del. Todd, W. S., Greenwood, Del.

\section{MICHIGAN.}

\section{Exhibit of fruits in season.}

Baldvin, W. Y., Palmyra. Dunkley c Co., Kalamazoo. Gaylord, IF., Adrian. Mich. Experiment Station. Moore, Wm. H., Palmyra. Fender, D. U., Adrian. 


\section{CALIFORNIA.}

dams, C. T., Nevenstle, Cal. Preserved peaches.

pmbrust, Henry, Stockton, Cal. Tines.

ipmsly d Company, J, K., San Francisco, Cai. Dried fruits.

gartiett Springs Co., San Franclsco, Cal. Bartlett mineral water.

barton Estate, Fresno, Cal.

Wines.

california Fruit Canners' Assoclation, San Franclsco, Cal. Palace of canned fruits.

california State Bonra of Trade, San Francisco, Cal. Fruits, seeds, cereals, etc.

cal. Wine Associntion, San Franclsco, Cal. Wines.

carlson-Carrier Co., Petaluma, Cal. Raw and manufactured sllk.

cantle Bros. Company, Fresno, Cal. Dried fruits.

chtehnex, Madam, San Franciseo, Cal. Orange marmalade.

Chaix \& Bernhard, San Franelseo, Cal. Wines.

Cooper, Elwood, Santa Iarbara, Cal. Olive oll.

Cunningham, J. J., Biges, Cal. Hemp and flax products.

Del Monte Miling Co., Sari Francisco, Cal. Cereal products.

Donovan, C. C., Santa Rosa, Cal. Sonoma Valley hops.

Doty, J. M., Livermore, Cal. Olive oll.

Eagle Storage and Packing Company, Fresno, Cal. Dried fruits, raisIns.

Ehmail Olive Company, Oroville, Cal. Ollve oil, plckled ripe ollves.

fisen Vineyard Co., Freano, Cal. Wines.

Frenmo Chamber of Commerce, F'resno, Cal. Fruits In solution, dried iruits, grains.

Fresno Home Packing Company, Fresno, Cal. Seeded raisins.

Flexible Mantle Co., Strckton, Cal. Lamp mantles.

Giannimi, Frnnk, Reedley. Cal. Ollve oll.

Golden Gate Packing Cu.. San Jose, Cal. Canned goods.

Goodrich, E., San Jose, Cal, Dried ripe ollives.

Gower, E., Fowler, Cal. Olive oil.
Gray John C., Oroville, Cal. Ollve oli.

Grifin \& Skelly Company, San Francisco, Cal. „Seeded ralsins.

Gugenheim d Company Snn Franclsco, Cal. Assorted dried iru'ts.

Gnudiach-Bundsehn Co., San Frauclsco, Cal. Wines.

Iammond, T. J., Fresno, Cal. Figs.

Harns, W. H., Fresno, Cal, Photographs.

Hersey, Philo, San Jose, Cal. Orchard photographs.

niggins, E. R., Fresuo, Cal, Photographs.

Hill, Thos., San Francisco, Cal. Scenic palnting.

Holt Bros., Stockton, Cal, Combined harvester.

Inmboldt Miling Co., Fortuna, Cal. Redwood doors.

I. X. L. Packing Comprny, San Francisco, Cal. Tamales, soups, etc.

Inmerial Prune Orchard. San Jose, Cal. Imperial prunes.

Inderxieden Co., J. B., Fresno, Cal. Dried fruits.

Italiau-Swiss Colony, Asti, Cal. Wines. Jackson, J. F.. San Franciseo, Cal. Napa soda mlueral water.

Keyes, W. S., Angwin, Cal. Winen. Kline, P., San Francisco, Cal. Wines. Ladies Silk Soclety, Sau Fraucisco, Cal. Hand-made silk flag.

La Motte, V. T., Sonoma, Cal. Persimmons in solution.

Mann, C. M.. San Francisco, Cal. Wines and braudies.

Martinelli, S., Watsonville, Cal. Apple cider.

Masson, Panl, San Jose, Cal. Champagne.

Mnxwell \& Iradge, Fresuo, Cal. Photographs.

May, Jude, Anburn, Cal. Orangex in jars.

Melco, G. M., Stocktou, Cal. Buhac. MeCord Sisters, Monterey, Cal. Pressed wild flowers.

McCubbin, J. B., Selma, Cal. Honey.

Minnewara Home Packing Company, Fresno, Cal. Fruits, Preserves, etc.

Mission Woolen Milla, San Francisco, Cal. Woolen fabrics.

Moore d Sou, H. H., Stockton, Cal. Ollve oll.

Mt. Shasta Mineral Springa Co., San Francisco, Cal. Shasta mineral water. 
Neadweys, P., Plaming Mills, Fresno, Cal. Plank.

Pacifc Tannery, Stockton, Cal. Leather.

Repsold \& Company, A., San Francisco, Cal. Wlnes and brandics.

Roeding, George C., Frenno, Cal. Olives, figs, plants.

San Luis obispo Board of Trade, San Luis Obispo, Cal. Seeds, cereals.

Sanger Lamber Co., Sanger, Cal. Lumber.

Santa Clara Fruit Exchange, Santa Clara, Cal. Dried fruits.

Scott \& Van Arsalale, San Franclsco, Cal. Woods.

Sekleman, A. G., Fresno, Cal. Silk cocoons.

Southern Pacife Company, Snn Francisco, Cal. Fiuits in jars, wood, scenle palntings, photographs, giobe.

Sperry Flour Co., Stockton, Cal. Cereal and cereal products.

St. George Vineyard, Fresno, Cal. Wlnes.

Stockton Chamber of Commerce, Stockton, Cal. Dricd fruits, cereals, photographs, pottery and clay.

Stockton Chicory Co., Stockton, Cal. Chicory.

Stockton Incubator Co., Stockton, Cal. Incubator.

Stockton Woolen Mills, Stockton, Cal. Blankets and woolen fabrics.

Thomas, I. H., Vianlia, Cal. Preserved peaches.

Tielman, J. S:, Freano, CaI. Big tree bark.

Weat d Son, Geo., Stockton, Cal. Wines and brandies.

Weatern Sugnr Refining Co., Snn Francisco, Cai. Assorted sugars.

Wetmore-Bowen Company, San Francisco, Cal. Wines.

\section{Exhibits of Southern California Products, under the auspices of Los Angeles Chamber of Commerce.}

Alamitos Sugar Conpany, Los Angeles, Cal. Beet sugar.

Akerman \& Tumey, San Diego, Cal. Ollve oll.

Art Leather Company, Los Angeles, Cal. Ornamental carved leather work.
Bachelor, G. H., Frultland, Cal, ce Brown smyrna flgs, in liquid. Cal. L

Banning Compauy, Los Angeles, Cal. Game and food fish made in in casts, caught In Catalina Bay.

Bonra of Trade, Pomona, Cal. Na. rel oranges in liquid, lemons in liquid.

Boetcher, H., Los Angeles, Cal. Chestnuts.

Bomita Orchard Company Fair. mont, Cal. Four valietles of almonds,

Brandt E Company, C. C., San Diego, Cal. Lemon juíce.

Bishop \& Company, Los Angelen, Cal. Glace frults, glace stuffed pruaes,

Bishop \& Company, Lon Angeles, Cai, Preserves, jams, jellies, spleed flgs, orangeate, grapefruitate, maras. chino cherries.

Cary-Smith, Louise, Pomonn, Cal. Sterllized grape juice.

California Conserving Co, Long Beach, Cal. Canned lobsters, clam juice, clam chowder.

California Fish Company, ros Angeles, Cal. Sardines, broiled mackerel, in tins.

Chamber of Commerce, Los Angeles, Cal. Ornamental dried fruits.

Chamber of Commerce, Lon Angeles, Cal. General display of stone iruits in llquid.

Chamber of Commerce, Los Angeles, Cal. Wax frult modeis.

Chamber of Commerce, Los Angeles, Cai. Slik cocoons, silk cocoon portier, artistic installation Los $A n$. geles County exhibit.

Chamber of Commerce, Los Angeles, Cal, Ornamental woods.

Chamber of Commerce, SantaAna, Cal. Oranges in Ilquid.

Chamber of Commerce, SnntaAna, Cal. Peanuts.

Cluamber of Commerce, Santa Ana, Cal. Dried truits.

Doty \& Donll, Ios Angeles, Cal. Patent lawn mower sharpener.

Edward Germain Wine Company, Los Angeles, Cal. Port, sherry, angellea.

Fdwara Vom Hofe, New York, $N$. Y. Game fish and reel.

Fullerton Walnut Growers' Association, Fullerton, Cal. English wainuts.

Griftth, A. P., Azrsa, Cal. Pomelo in liquid.

Hill \& Sons. Ollve oll.

Hill \& Sons, Los Angeles, Cal. Plckled rlpe ollves. 

a1, Los Angeies, Cal. Ginger aie, puritas ithis water, komei, juice of the pomelo, orange, tango.

in urchow, J. H. J., San Gabriel, Cal. Washington navel oranges.

prne, H., Los Augeles, Cal. Olive oil.

ierne, H., Los Angeles, Cai. La crescents relsling, la crescenta hock, la crescenta sauterne.

jerne, H., Los Angeles, Cal. La crescents cabernet, ia crescents burgandy, la crescento zinfandel.

jevne, H., Los Angeles, Cal. Port, sherry, angelica.

Last, C. F. A., Los Angeles, Cal. Port.

Leflngwell, C. W., Whittier, Cal. Eureka lemons.

Los Angeles Public Schools, Los Angeles, Cal.

los Nietos, Ranchito Wainut Growers' Association, Incorporated, Rivera, Cai. Soft and hard sheil Engllsh wainuts.

Lour \& Gerling, Pomona, Cal. Drled pears, drled peaches.

Lndwig, Henry, Los Angeles, Cal. Biack walnuts.

Ladwig \& Mnthewes, Los Angeles, Cal. Orange-cllng peaches in llquid, biack diamond piums in ilquid.

Mnzana Colony, Manzana, Cal. Soft shell aimonds.

Markh, Miss Bessie A., South Pamadena, Cal. Candicd viojets, candicd rose leaves.

MeEven, D. H., Pomona, Cal. Ollve oli.

Mclntyre, J. H., Sespe, Cal. Extracted sage honey.

Mchanghin, S., Los Angeles, Cal. Seif-adjustlng printing press for photoengraving.

Mendelson, M. H., Ventura, Cal. Comi honey.

Nefi Laborntory, La Micndo, Cal. Kitro tonic, made from grape fruit.

North Ontario Packing Company, Los Angeles, Cal. Dried peaches, pears, prunes and nectarines.

ortegn, F. C., Los Angeles, Cal. Prepared Chile pcppers in tln and giass, pepper saucc, Chile sauce.

Pasadena Pablic Schools, Pasadena, Cai.

Picher, Anna B., Pasadena, Cal. Reiles.

Pomona Bonrd of Trnde, Pomona, Cal. Flame tokay grapes in liquid.
Pomona Public Schools, Pomona, Cai.

Rnpp, J. B., Colegrove, Cai. Pineapple in ilquid, monstera deilclosa in ilquid.

Richardson, C. H., Pasadena, Cal. Tangerines in liquid.

Richardson, C. H., Pasadena, Cal. Guavas in iiquid.

Rivers Brothers, Los Angeles, Cal. Black Hamburg grapes, in liquid; biack maivolsie grapes, In liquid.

Schmucher, Frank, Los Angeles, Cal. Carbon portraits.

Schumacher, No, 107 North Spring street, Los Angeies, Callfornia. Oldest Estabiished Photographic Studlo in Southern California.

This exhibit has recently been awarded a medai for exccilency at the late Paris Exposition. This finmous studio has also received medals from the World's Fair. Goid Medal. Highest Prize, above ail other competitors, at the Mid-Winter Falr, San Francisco, Callfornla, in 1894.

Partles visiting Southern Cailfornla should not fall to secure work of this celebrated studlo.

Seconda Guasti, Los Angeles, Cal. Port, sherry, maiaga, muscat, angellca.

Sierra Madra Vintage Company, Lamanda, Cal. Brandy of 1894.

Sierra Madra Wine Company, Lamanda, Cai. Port, troussean port, 1885; malvoisa port, 1885 ; sficrry, 1885; muscat, 1885; angelica wine.

Sormano, G., Los Angeles, Cal. Zinfandel.

Sormano, G.. Los Angeles, Cal. Port, angelica, sherry.

Sormano, G., Los Angeler, Cal. Grape brandy.

Sonthern Cnlifornin Deciduous Fruit Association, Los Angeies, Cal. Dried pears, pruncs, penches and ralsins.

Sonthern Callornin Frnit Exchange, Los Angeles, Cal. General dispiay of citrus fruits, Washlngton navei oranges, Valencia iate oranges, seedling oranges, triumph pomeio lemons, cltron of commerce.

Southern Callforuin Wine Company, Los Angeles, Cal. Grape brandy.

Southern California Wine Company, Los. Angeies, Cal. Port, angeilca, sherry, orange, muscat.

sonthern Califoruin Wine Company, Ios Angeles, Cal. Relsiling, sautern, 
Southern California Wine Company, Los Angcles, Cal. Zinfandel, burgundy, blackberry wine.

steel, W. R., Florence, Cal. Cornichon grapes, in liquid; flame tokay grapes, in ilquid.

strong, Mrs. W. W. R., Whittier, Cal. Pampas plumes.

Taft, C. P., Orange, Cal. Loquots. Tart, C. P.. Orange, Cal. Adranee loquots, in liquid.

Tengue. R. M., Snn Dimas, Cal. Kumquots, Japanese orange, in llquid; Valencla late oranges.

Thorp, S. R., Los Angeles, Cal. Engiish waluuts.

waters e Company. C. H., Pomona, Cal. Canned fruits.

Willians Co., George, Lox Angeles, Cal. Willams' sauce for meat, fish, etc.

Wright, A. W., Pomona, Cal. Lemon juice.

Wright Brothers, Sunland, Cal. Olives, in liquid.

Yucen Mannfacturing Company, Los Angeles, Cai. Tree protector, surgeon's spllnts, Insoles, etc., made from succa.

\section{MEXICO.}

Arellanes, Jonginos, Ocotlnn, Oaxaca. Mezcal, (made from agave plant).

Andinot, Franciseo, Agungenilentes, brandy.

Barrion y Murga, Mexico. Red wlue. D-F.

Becerrn. Fabra y Cin, Ineuspana, Tabasco. Brandy.

Cama Colorado, Mexico. Cognne, Rum and Brandy. D-F.

Camillan, Pliar, Enscnada, B. C. Brandy.

Castillo, Hermanon, Snuta Elena, Durango. Mezcal (made from agave plant).

Chalon, Hermanos, Apam, Hidalgo. White wine, champague.

Compania Destiladora "La Kentuky." Monterrey, N. I., Whiskey and Mezcal (made from agave plant).

Compania Destindora, Mexico. Cognac. D-F.

Cnevan, Andrea, Minhuntian, Onxaca. Mezcal (made from agare plant).

Crux, Eulogio, Santo Tomas, Oaxaca. Mezcal (made from agave plant).
Cruz, Snbas. Guadalajarn, Jallsco. Tequila (made from agave piant).

Davila, Tennelo, Gundalajara,
Jailsco, muscatel.

Dellum y Companin, Teple, Tepic. Banana brandy.

Destllerix Del Torreon, Torreon, Coabulla. Whiskej.

Encinas, Alfredo, Sahuaripa. Sonora. Mezcai (made from agare plant).

Fnbrica "La Escondida," Tepie, Teplc. Brandy.

Filizola, Herminos, Cinind Victoria. Tamaulipas. Mezcal (made from agave plant).

Gareia, Jesus, San Lnis Potosi, s. L. $P$. Mezcal (made from agare plant).

Garcin, Jonquin, Texcoco, Mexico. Brandy aud cognac.

Gnrein, Jonquin, Texcoco, Mexico, Vermouth.

Garcia, Hermanos, Otumba, Mexico. Brandy (made from pulque).

Gonzalez, Trevino Lorenzo, Parras, Coahuila, cherry and port wine.

Gonmnlez, Trevino Lorenzo, Parras, Coahuila, red wine.

Gonznlez, Trevino Lorenzo, Parras, Coahulla, white winc, brandy, etc.

Golberno Del Fstndo De Morelos, Cuernavaca. Mezcal (made from agare plant).

Goblerno Del Fstado De Zacntecas. Zacatecrs. Mezcai (made irom agave plant).

Gnzman, Bernabe, Ocotinn, onxaca. Mezcal (made from agave plant).

Jarquin, Marinno, Zoquitlan, Oaxaca. Mezcal (made from agave plant).

Jesus Jnan Pedro, Minhuatlan, Oaxaca. Mezcal (made from agare plant.)

Ledesma, Genovern, Zimapan, H1dalgo. Mezcal, (made from agave plant).

Ledesma, Federico, Zimapan, Hidalgo. Mezcal (made from agave plant).

Lopez, Melesio, Sinnion, Sinnloa. Mezcal (made from agave piant).

Maldonado, Ramon, Monterrey, N. L. Cognac.

Mantila, Jose M., Snn Juan Bautista. Tabasco. Mezcal (made from agave plant).

Martinex, Jose, Tlacolula, Onxnca. Mezcal (made from agave plant). 

atinex, Jann, San Pedro Quia-
togl. Oaxaca. Mezcal (made trom isare plant).

rtinex, L., Hostotipaquillo, Jasco. Mezcal (made from agavo iunt).

intinez, Viuda De, Guadalajara, Sallsco. Tequila (made from agave plant).

endoza Nabor Sucesores, ha Paz, Baja Callfornia. Mezcal (made from igave plant).

lendoza, Simon, La Paz, Baja, callerula. Mezcal (made trom agave plant).

Yora, Ramon De La, Guadalajara, Jallsco. Tequlia (made from agave plent).

ynos, Mannel, Tlaltizapan, H1dalgo. Mezcal (made from agave plant).

rnez, Juan, Stnaloa, Sinaloa. Mercal (made from agave plant).

achoa $y$ Aviles, Fuerte, Sinaloa. Brandy.

ortegu, Carmen, Hermosillo, Sonora. Ilezcal (made from agave plant). saradn, Miguel, Ueotlan, Oaxaca. Mezcal (made from agave plant.)

Pelro, Hermanos, Hacicnda de Perlcos. Slnaloa. Mezcal (made trom ugave piant).

Aamires E Hifos, San Luis Potos, S. L. P. Mezcal (made from agave plant).

Rancho, Grande, Frennillo, Zncatecas. White wlne.
Remus, Hifas De, Guadalajara, Jallsco. Brandy.

Retes, Hermanos, Hacienda de pericos. Sinaloa. Mezcal (made from agave plant).

Rlquelme, S., Mexico. Brandy. Romero, Francisco, Tequlla, Jalisco. Mezcal (made from agare plant).

Samperio, Ygnacio, Pachuca, Hidalgo. Mezcal (made from agave plant).

Socledad Agricola, Mexico. Mexcal (made from agave plant.). D-F.

Solorzano s Sanz, Mexico. Brandy (made from pulque). D-F.

Tardos, Jallo, Mexico. Whiskey, Cognac and rum. D-F.

Teran, Juan, Ciudad Victoria, Tamaulipas. Mezcal (made from agave plant).

Torres, Hermanow, Nazan, Darango. White wine.

Valdes, Abundio, Aguacallente, Sinaloa. Brandy.

Vargas, M., Collma, Collma. Red wine.

Villareal, J. M., Mexico. Cognac. Cognac. D-F.

Zamora, Cipriano, Miahuatlan, Oaxaca. Mezcal (made from agave plant).

Zertuche, A., Ciudad Romero Rublo. Coahulia. Mezcal (made from agave piant). 
CATALOGUE OF SUGAR EXHIBIT OF THE ARGENTINE REPUBLIC, CROP 1898-99.

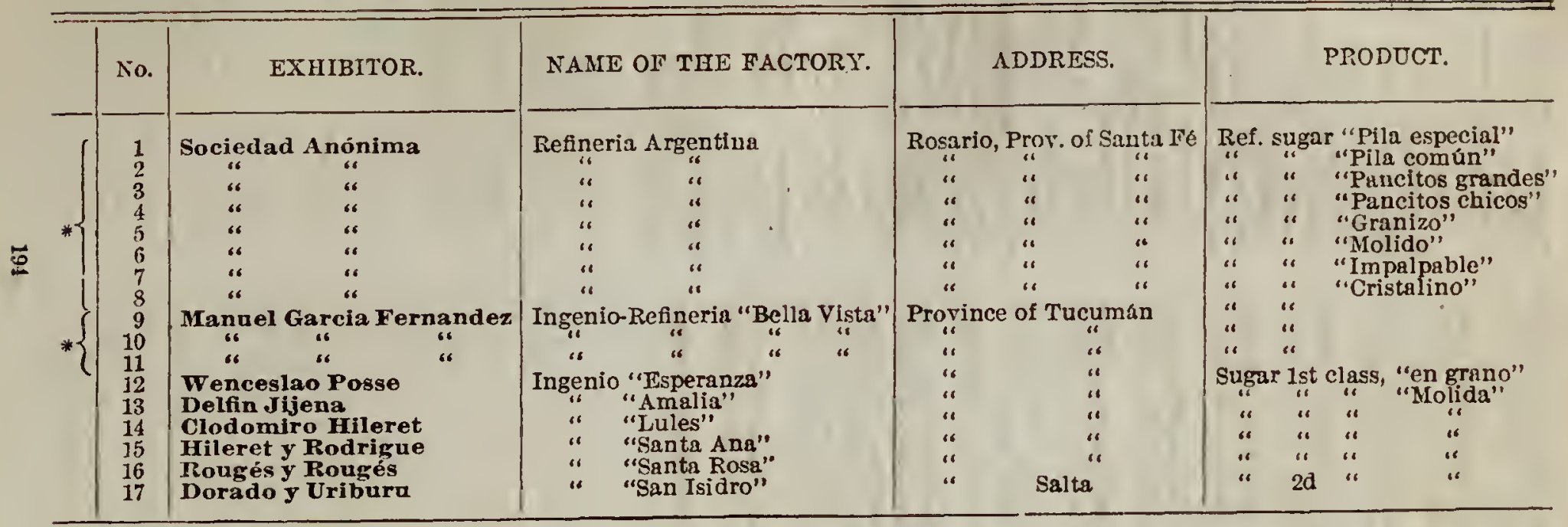

* Collective exhlbits. 


\section{Floriealtare.}

\section{William Scott, Asst. Sapt.}

Exhibits of Floriculture are to be found in the Rose and Horticultural iardens, in the Conservatories at the east and west ends of the Horticulture 3alling. The exhibits of Aquatics are to be found in the basin south of the Ilannfactures and Liberal Arts Building, in the basin south of the Machinery ad Transportation Building and on the margin of the Mirror Lakes. Many entries for the Cut Flowers Exhibitions cannot be given now as entries will not be made many days previous to the exhibition.

\section{EXHIBITORS.}

Imerican Ginseng Co., Rose H111, N. Y. Bed of glnseng.

Bobbink \& Atkins, Rutherford, N. J. Evergreens and shrubs.

Bogue, Relson, Batavia, N. Y. Hybrid perpetual roses (1300).

Barpee Co., Atlee, Philadelphia. 5 beds. Coleus (2 varletles), begonlas (2 varleties), burbank roses.

claces \& Bodalington. New York. Spanlsh Irls $(10,000$, in 8 beds.)

conard \& Jones, West Grove, Pa. Cannas.

Cook, John, Baltimoxe, Ma. Bed of new rose, Admiral Schley.

Dingee \& Conard, West Grove, $\mathrm{Pa}$. Summer bloomlng roses ( 2 beds.) Dreer, Henry A., Philadelphia, Ps. 31,000 square feet of beds containlng tullps, byaclnths, narclssus, pansles, grasses, herbaceous plants ( 50 varlethes), begonlas, verbenas, cannas, geranlums, lantana, Japanese maples, celosla, pholx, petunlas, asters, dlanthus. gallardla, tritoma, lawn grass; aquatics: nympheas $(50$ specles $)$. victorla regla (basin south of Machlnery Bldg.), victorla trickerll.

Eicholtz, Henry, 'Wayneaboro, Pr. Cannas ( 2 beds).

Eisele, Christian, Philadelphia, Pa. Pansles ( 3 beds), carnatlons ( 3 varieties), geraniums.

Eitsele, W. G., Went End, N. J. Canuas ( 3 beds.)
Ellwanger \& Barry, Rochester, N. Y. Hybrid perpetual roses (2000), hardy phlox, collection of hardy trees, and shrubs. Mount Hope Nurserles. Established over 60 years. Trees, frult trees, small frults, grapes, ornamental trees, shrubs, shade trees, hardy roses, hardy plants, etc. Illustrated catalogue free.

Henderson Co., Peter, New York. Lawn grass, garden implements, sprlng fowerlng bulbs $(70,000)$, large collectlon summer blooming plants. occupylng the entlre space between Horticultural Bullding and north of Canal.

Jackson E Perkins, Newark, W. J. Hardy roses, cllmblng roses.

Lothrop H Hegins, East Bridgewater, Mass. Dahlias (3000 plants in 3 beds.)

Maun, Matthew D., M. D., Huffalo. Delphlnlums.

Meehan Son, Thos, Germantown, Pa. 75 speclmen evergreens.

Michell, Ienry F., Philadelphin, Pa. Spring flowering bulbs ( 3 beds).

Moon Co., Wm. H., Morrisville, Pa. Collectlon of evergreens, retlnosporas.

Park Floral Co., Denver, Colo. Aqullegla.

Parka and Bonlevardo Cummisslon. Detrolt, MichIgan. Troplcal 
Parsons \& Son, Flushing, N. Y. Ilex crenata ( 1 bed), Japanese maple (1 bed.)

Plerson \& Co., F. R., Tarrytown, N. Y. Tulips $(42,000)$, hardy hydrangeas, crlmson rambler roses, cannas, musa, about 20 varletles summer blooming plants.

Rea Bros., Norwood, Mass. Collectlon hardy pholx.

Scott, William, I uffalo. 200 plants of altheas.

Smith Son, Nathan, Adrian, Mich. Cannas ( 1 bed.)

Smith, E. C., Geneva, N. Y. Rudbekia golden glow.

vaughan, J. C., Chicago, I11. 17 beds contalning hardy phlox, pansles, geranlums, begonlas, other varletles summer blooming plants.

Vick's Sons, Jas., Rochester, N. Y. 6 beds spring flowerlng bulbs to be followed by summer blooming plants.

Ward, Charles W., Queens, N. Y. Geranlums (3 varieties), McKlnley cannas.

Whitney-Ecksteln Seed Co., Buffalo. Lawn grass.

Zimmerman, C. D., Buffalo. Tullps and hyacinths (1 bed,) cannas, tropical plants.

Zirnglebel, Deny\&, Needham, Masw. pansies (1500).

\section{CONSERVATORIES.}

Bunalo Botanic Gindens. Collectlon of palms and cycads.

Burpee, W. Atlee, Philadelphia, Pa. 75 sq. ft. sweet pea blooms.

Chaduorn Mrg. Co., Newburgh, $N$. Y. Exhlbit of automatic heat control and ventllatling apparatus.

Connecticat Horticaltnral Exhlblt. Vlews of park scenery.

Dreer, Henry A., Philadelphia. 250 sq. ft. grasses, seeds, bulbs, cut flowers.

Dreer, H. A., 714 Chewtunt st., Phliadelphla. Collection of rancy caladlums and colfectlon of palms and dracaenas.

Grof, H. H., Simcoe, Ont., 120 sq. ft. gladiolus vlooms. The stock exhlbited by me, also earller Introductlons, can be secured from Mr. Arthur Cowee, Berlin, N. Y., who is the Unlted States representatlve and grower of same.

Hendermon \& Co.. Peter. New York. Collectlon of fancy caladiums and Boston ferns.
Krick, W. C., Brooklyn, N. Y. Flower vases, flower stands, florists supplles.

Orlando Pineapple Association, Orlando, Florlda. Collectlon of plneapple plants in frult.

Vick's Sons, Jas., Rochester, N. Y. 200 sq. ft. seeds, bulbs, cut flawers.

Vlck's Seeds,

Vlck's Plants,

True to Name,

Sure to Grow.

Ward, C. W., Queens, N. Y. 1350 sq. ft. geranlums, pelargonlums, be gonlas.

Wittbold Co., The Geo., Chicago. $80 \mathrm{sq}$. ft. collection of new fern, "Nephrolepls Wlttboldll."

Zlmmerman, C. D., Buffalo. 26 sq. ft. collectlon of follage plants.

\section{MEXICO.}

\section{The following plants located in bed west of Women's Building.}

Collection of 500 single Tuberous Begonlas.

Collectlon of 500 double Tuberous Begonlas.

Amarylls Formossislma, Bessera Elegans, Cyclobothra, Flava, Mllla Bifora, Zephyrantes Alba and Z. Rosea, Tlgridlas Pavonla, Conchlfora and Rosea, Pancratulm Sps.

ORCHIDS-Brassavola Glauca, Lycaste Aromatlca, Brassia Verrucosa, Lycaste Cruenta, Catleya Citrlna, Mormodes Sps, Chysls Aurea, Odontoglossum Blctonlense, Chysis Bractescens, O. Cervanteslo, Epldendrum Falcatum, 0. Cltrosnum, E. Nemorale, 0 . Cordatum, E. Vitellínum Majus, 0 . Insleayi, Laella Albida, $G$. Maculatum, Lae lla Anceps, O. Nebulosum, L. Ánceps Alba in var, 0 . Rechenhelml, L. Autumnalls, Ónlcidlum Bicalosum, L. Atrorubens, On. Cavendishanum, L. Majalls, On. Cebolleta, L. Majalls Alba, On. Tigrinum, L. Majalls Rosea, On. Ornythornychum, On. Stelligerum, Sobralia Macrantha, On. Tigrlnum, Stanhopea Tlgrinla, On. Ungulculatum, S. Oculata, Schomburkla Tiblclnls, S. Martlana.

CACTACEA.-Ahalonlum Flssuratum, Cereus Serpentlnus, A. Lewlnl, C. Euphorbloldes, A. Prismatlcum, C. Flagelliformis, A. Sulcatum, C. Gemantus, A. Williamsi, C. Pascanus, C. Puginlferous Geometrizans, C. Spectossisimus, other unclassifled Cerụs. 
ICAINOCACTUS.-Begulnl, E. Multicostatus, Bicolor, E. Ornatus, E. CornIgereus Flavispluus, E. Pfelfferl, E. crispatus, E. Recurvus, E. Electracanthus, E. Robustus, E. Grusonl, E. Sheerl, E. Helophorus, E. Plllsus, E. Horizonthalonlous, E. Stelnessl, E. Ingens, E. Texensls, E. Lancifer, E. Turblnlformis, E. MCDowelli, E. Uncinatus, E. Lophothele, E. Cereus Berlandleri, E. Caespitosus, E. C. Ehrenbergi, E. C. Merkeri, E. C. Pectlnatus. MAMILLARIA. - Aplanta, M. Caret1, M. Circhlfera Longispina, M. Cornlfera, M. Cornuta, M. Domonoreras, M. Donati, E. Echinata, M. Elegans, M. Elephantidens, M. Ererta, M. Erlacantha, I. Heeseana Longlsplna. M. Lassomerl, M. Micromeris, M. Micromerls Greggl, M. Mutabllis, i. Nirea, M. Nicbolsoni, M. Parkinsoni, M. Pfelfferl, M. Plumosa, M. Potosina, M. Recurrata, M. Recurveus, M.' San- guinea, M. Solymoldes, M. SplnosslsIma, M. Stella Aurata, M. Paltoni, Pllocereus Fosulatus, PC. Hoppenstedti, PC. Senells, Pelecjphora iscellformis, Opuntla Mlcrodasy, Manil. laria Nivla Crlstata, M. Allcromeris Cristata, M. Lassomerl Cristata, Cereus Columbrinus Cristata, Cereus Pas. camus Cristata.

Latanla Borbonlea, Kentia Belmoriana, Kentla Forsteriana, Corypha Australls, Phlenlx Canarlensis, Cham. edoria Elegans, Chamedora Gracilis.

Collection of fancy Pelargonlums.

Collection of Camelias.

TENDER CLIMBING PLANTS-Cobea Scandeng, MIna, Lobata.

NATIVE WILD PLANTS-THllandaslas, Sellanigella Lepldophyla, Agave Americana, Americana Varlegata, A. Tehuacanensis, A. Victoria Reglna. 10 other unclassified Agaves. 


\section{Forestry Building. Frederie W. Taylor, Supt. F. de P. Tounsend, Asst. Supt.}

\section{EXHIBITORS.}

Berlin Mtila Company, N. H. Rellef maps of Maine and N. H. townships, paper pulp, sulphlde, wood preservatlves, model lumber camps, speclmens of game.

Brandel, Philip, Bnfifo, N. $Y$. wood mosales.

Bridgeport Wood Finishing Co., New Milford, Cona. Wood specimens.

Cornell University. Rellet mays of their forest, photo.

Freeman, N. G., Bufialo, N. Y. Wood and bark noveltles.

George Pine Turpentine Co. Turpentine, olls, etc.

Hopkins, A. D., W. Va. Insects destructlve to forest trees.

Hough, Romeyn B., Louisville, Ky. Veneers.

Idaho, State of.

Lomisian, State of. Insects inJurlous to forest trees.

Lewis, Gracenna. Lenf charts.

Manhattan Spirit. Co., Bufralo, N. Y. Alcohol and by-products.

Mexieo. Specineng of wood and forest products.

Michigan, State of.

Mismonri, State of. Spccimeng of wood and forest products.

Morley Bros., Saginaw, Meh. Logglng tools, etc.

N. Y. Fish, Forest and Game Commisslon. Speclmens of woods and speclmens of fish and game.

N. Y. State Musenm. Fntomological collectlon and relief map of Adlrondacks.

Nonpareil Cork Mfr. Co., Bridgeport, Conn. Floor and walnscot tllIng. Durable, artistlc, nolseless. Plpe coverlng for all uses. Sheet cork. 'The best cold storage Insulation. See our exhiblt. Write if interested.

ontario, Province of.

Oregon, State of.
Rensmann \& Deen, Eaton, ohio. specimens of finished hard Food.

Shiras, George H. Pictures of wild game.

Spiritine Cliemical Company, Wlimington, N. C. Wood preservatlve. Sole manufacturers of "Splrittlne." We are here to interest the visltors to this Exposition in the products of the long leaf yellow pine tree; especlally our "Splrittlne "Vood Preserver," whlch has stood the test successfully for fourteen years. Call and get one of our booklets contalning full and valuable Information.

Tindle \& Jackson, Buffalo, N. Y. Cooperage stock, handles, etc.

Washington-Game; land and aquatlc birds, mammals and food fishes. Gallery, west end.

Wisconsin, State of.

\section{MEXICO.}

Alvarez, M., Chlapa, Gucrero. Specimens of indlgo.

Aneioln, M., Inehnmin, Michoacan. Specimens of lndigo.

Ayuntamiento de Mincatlan, State of Morelos. Collectlon of woods.

Arninmiento de Tlaltixapan, State of Morelos. Collectlon of woods.

Barreto, Gregorio, Colima. Collection of woods.

Barron, Forbes y Cia, Tepic, Tepic. Collection of woods.

Barron, Forbes y Cia, Tepic, Tepic. Speclmens of rubber.

Becerra Fabre, Belisario, Macuspana, Tabasco. Speclmens of achiote.

Camaeho, I., Ias Conchas, Chiapas. Specimens of rubber.

Carpena, Gila A. de, Tepic, Tepic. Collection of woods.

Cesena, E.. Mexico, Distrito Federal. Speclmens of damlana. 
compania Colonizadora, Progre so, Yucatan. Collection of woods. cunania Colonizadorn, Progreso, Yucatan. Specimens of chewing gum.

compania Del Ferrocarril Sud Orjental, Merlda, Yucatan. Collection of woods.

cortes, Remigio, Tincotaipan, Verscruz. Collection of woods.

copinosa, J. M., La Libertad, Chiapas. Specimens of indlgo.

Fragoso, Nestor, Motomintia, Cliapas. Specimens of gums.

ruentes Primitivo, Tetecain, State of Morelos. Collection of woods. Fuentes. P.. Tetecria, Morelos. Specimens of gums.

Coblexno del Fstado de Aguarcrlientes, Aguascallentes. Collection of woods, braudy, etc.

Coblerno deI Estado de Chinpas, Tuxtia Gutlerrez. Specimens of rubber, resins, Indigo, achlote, amolllio $\mathrm{y}$ jabonclllo.

Goblerno del Fstado de Collma, Collma. Collection of tanning barks. Gobierno del Eatndo de Colima, Colima. Speclmens of cascalote.

Gobferno Del Eatado De Durango, Durango. Fruits in wax.

Gohferno del Eatado de Guerrero, Chllpanclngo. Speclmens of gums.

Goblerno del Estado de Nichnacan, Morella. Speclmens of axe.

Goblerno Del Estado de Onxacn, Oaxaca. Fruits ln wax.

Goblerno del Estalo de Puebla, Puebia. Collectlon of woods.

Goblerno del Eatrdo te San Luis Potosl, San Luis Potosl. Collection of woods.

Goblerno Del Estralo De Sonora, Hermoslllo. Fruits in wax.

Goblerno del Estado de Tabasco. San Juan Bautlsta. Collectlon of tanning barks.

Gohicrno del Extado de Tabasco, San Juan Bautlsta. Collectlon of woods.

Go'icrno del Estado de Tabasco, Su Juan Bautista. Speclmens of achlote, chewling gum, resin, rubber and cotton.

Goblerno del Estado de Veracruz, Xalapa. Collection of woods.

Goblerno del Territorio de Tepic, Tepic. Collectlon of woods.

Gonzales, Gil Jone; Cnnduacrn, State of Tabasco. Samnle of wood.
Conzales, Peilro, Candnacrn, State of Tabasco. Sample of wood.

Hernander, Gregorio, Cunduncan, State of Tabasco. Sample of wood.

Junta Local De Paebla, Puebla. Fruits in wax.

Martinex, J. M., Zimntinn, Onxrea. Collectlon of tanning barks.

Merorilo, Manuel, Cundunenn, State of Tabasco. Collectlon of woods.

Municipio de Jonneatepec, Morelos. Collection of tanulng barks.

Municipio de Jomacatepec. Morelos. Specimens of gums.

Priacios, S., Motozintia, Chiajns. Specimens of gums.

Pallas y Cin, Isla del Carmen, Campeche. Speclmens of cheving gum.

Parres de la Fuente, Junn. Ia Provldencla, Mexico. Specimens of roots.

Penaflel, Esther, Mexico. Frits in wax.

Ramos, Hermanos, Mexico, Distrlto Federal. Speclmens of chewlng gum and rubber.

Robles, L., Sinacomitinn, Colima. Speclmens of chewing gum and lubber.

Romnno Cin, Mracuspann, Tabasco. Collection of woods.

Rosado Desiderio, San Junu Bantlsta, Tabasco. Specimens of jaboncillo.

Rosas, Prefecto, Amacumar, State of Morelos. Collection of woods.

Salaznr, Mauro, Montemorelos, Nuero Leon. Collection of woods.

Santa Crur, Franciseo, Colima, Collma. Collection of woods.

Secretarin de Fomento, Mexico. Collectlon of woods.

Secretaria de Fomento, Mexico. Distrlto Federal. Speclmens of gums, medicinal plants and chewing gum.

Soclednd Agricoln, Mexico. Fruits in wax. D-E.

Solorrano, Salvador, Mexico. Collection of woods.

Solormano y Sanx, Jose, Mexico. Collection of woods.

Torres, C., Los Helotes. Collection of woods.

Vargar, F. S., Chila, Tepic. Specimens of chewing gum.

Vasquez; Pahin, Thalłnango, State of Morelos. Mesquite gum. 


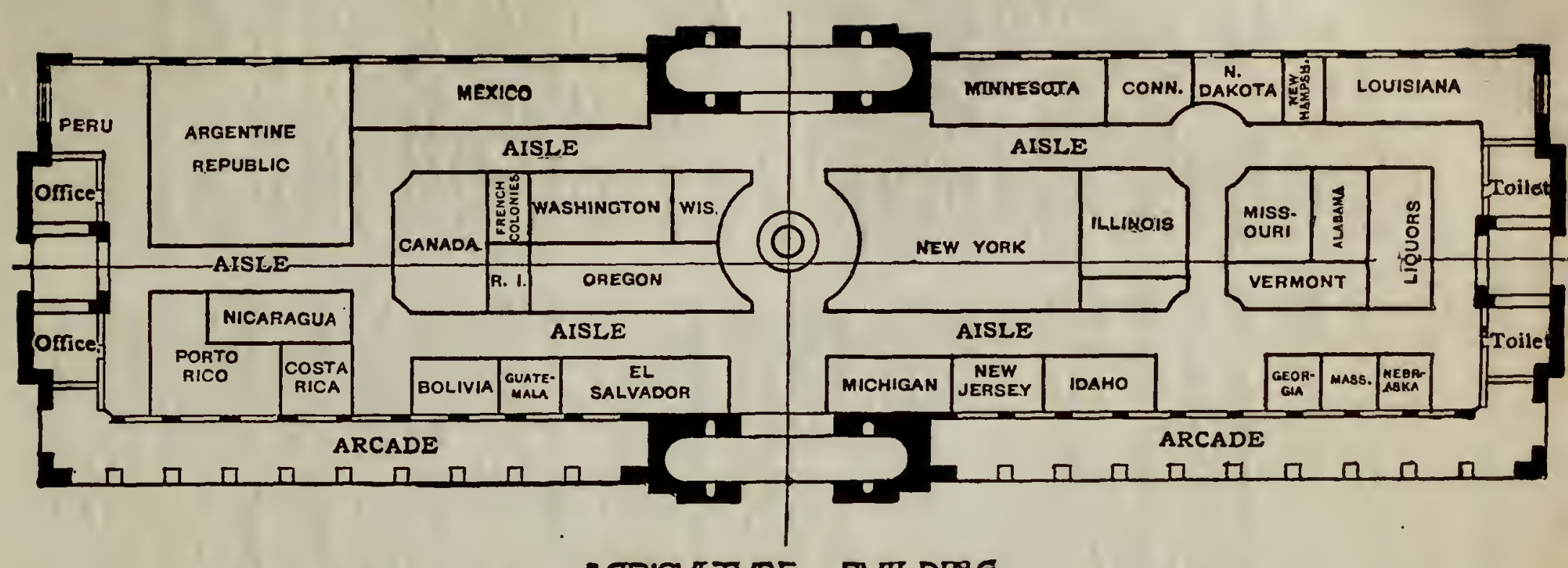

AGRICVLTVRE BVILDITG. 


\section{Agriealtare Bailding. \\ F. A. Converse, Supt. \\ B. H. MeManus, Asst. Sapt.}

The ground floor of this building is shown on the opposite page, and the arrangement of exhibit spaces is shown thereon. Those exhibits located in the gallery are so indicated.

\section{THE EXHIBITS INCLUDE:}

\section{Grasses and Forage Crops, Cereals, Tubers and Root Crops, By-Products used for Animal Foods, Agricultural Products, Fibers, Fertilizers, etc.}

\section{EXHIBITORS.}

Apiarian Frhibit of Canadian Government. Gallery, west end.

Aplarian Exhibit of $N$. $Y$. State Commlsslon. Gallery, west end.

Atchimon, Topeka d Santa Fe Rallway system, The, Chlcago, Ill. Dlorame. Electrlc dlorama, Grand Canjon of Arlzona ln gallery west end of Agrlcultural Bullaing; magniflcent scenle spectacle. Also serles of 100 postal views ln Postal Exbiblt U. S. Government Bullalng.

Badow, P. A., Cayes, Hayt1. Bbl. Rum. Maln foor, west end.

Barbancourt \& Co., Port-au-Prince, Hayti. Bottled rum. Main floor. West end.

Battle Creol Pure Food Co., Battle Creek, Mich. Breakfast food.

Buffalo Diatilling Co., Butralo, N. Y. Whiskies, etc. Ground Boor, east end of building.

Cataract City Milling Company, Nlagara Falls, N. Y. Flour, ete. Gal. lery, east end.

Choctaw, Oklahoma \& Gule Ry. Agricultural products and literature. Gallery, east end.

Conrad Stein'n Sons, New York, N. Y. Malt llquors. Gallery east end. Lager beer brewers. Beer bottled especlally for export and family trade. Look up our exhlblt and recelve souvenlrs.

Cook \& Bernhelmer Co., New York, N. Y. Whlskles, club cocktalls, etc. Gallery, east end.

Crothera, L. M., Crothers, Pa. Cereals, etc. Gallery, near center.

Dominion of Canada. Canned frults, vegetables, foods, etc. Gallery, near center.
Filnt Ealy \& Amer. Trading Co., New York City. Natlve Phifipplne hemp cleaner and decortlcator. Gal. lery, near center.

Gerhara Lang Brewing Co., Burfalo, N. Y. Lager beer. Gallery, east end.

Hollhan Bros., Lawrence, Mawr. Liquors, ete. Gallery, east end.

Labatt, J., London, Ont. Beer, ales, ete. Ground foor, east end of bullalng.

Meadvilie Distiling Co., Mendvllle, $\mathrm{P}_{\mathbf{Q}}$. Whiskles. Ground foor, east end of bullding.

National Beet Sagar Ammociation, Buffalo, N. Y. Beets and Beet Sugar, etc. Gallery, west of center.

N. Y. State Arricultural Experiment Station, Geneva, N. Y. Gallery, east end.

Ontario Beo Keeperg' Association. Rees and boney. Gallery, west end.

Overholt \& Co., A., Plttburg, Pa. Whiskles, etc. Ground floor, east end of bullding. Pennsylvanla Pure Rye Whiskey, "bottled in bond" or by the barrel.

Petty, W. L. \& Co., Rocks Monnt, N. C. Leaf tobacco. Gallery, near center.

St. Loula o San Francisco $R$. $R$., New York, N. Y. The Frisco Llne-St. Louls and San Franclsco Rallroad is a line traversing Alabama, Mlsslssippl, Arkansas, Mlssourl, Kansas, Indlan Terrltory and Texas. Its mineral and agricultural resources almost unlimited. Exhiblt on the South Wall, Agriculture Bldg. 
Sonthern Railway Company, Washlngton, D. C. Palntings. East slde of north entrance to building.

The A. I. Root Co., Medina, ohio. Bee leepers' supplles. Gallery, west end.

The W. T. Falconer Co., Jnmestown, N. Y. Bee keepers' supplles. Gallery, west end.

The Dickinson Company, Chicago, Ill. Seeds. Gallery, east of center.

U. S. Gort. Agricultural Experiment Station. Gallery, east end.

Vermont Maple Sugar Makers' Ansoclatlon, Randolph, Vt. Maple sugars and syrups. Main floor, east end.

Wupperman, J. W., New York, N. Y. Angostura bltters. Ground floor, east end of bullding.

\section{SAN SALVADOR.}

The Govcrnment has made extensive exhiblts of Coffee, Rice, Cereals. Vegetables, Tobacco, Sugar, Wools, Ores, Minerals, Books, Music, etc.

The individual exhibitors are as follows :

Angulo, Dr. Nicholan, San Vincente. Coffee, Indigo.

Arlia \& Andraie, "Santa Roøa." Gold and silver ores.

Arncena, Mrx. Juana de, San SaIvador. Sllk textures.

Belicave, Sautiago, "San Imiro." Copper orcs.

Bengoa e Co., San Salvador. Chocolate and candles.

Blaneo \& Tozano, Department of La Llbertad. Coffee.

Carreran \& Co., Mensrw., "La Azrora." Cigarettes.

Chavez, Narciso, San Salvador. Canelon wood desk.

Dinz, Josefa Bulnes de. Cigara.

Duke, Rodolfo, "La Labranza." Cofice.

F. de Pena, Mrж. Josefa, Suchitoto. Cigars.

Escalante, Miss Sarah, San Salvador. Handkerchlef.

Eacobar, Jenn: G. Penberry coffee.

Ewpinoxa, Fernando Avila, "Jocoro." Gold and sllvcr ores.

Goldtree Iieber a Cr., San Salvador. Balgam.

Gomez, A., "Chapeltique." Gold and sllver ores.

Gonzales. Dr. Dario, san Salvacor. Medicinal plants, balsam, etc.
Gonzalez, Emilio, Gold and sllver ores.

Comacaran.

Hernandez, Dr. A., San Salrador. Medlclnal plants.

Hernandez, Misn Julia, San Salvador. Handkerchlef.

Hill, Jamen, Department of Santa Ana. Peaberry coffee.

Iralco, Indian Women of, Sonwonatl. Sllk belt.

Lemus, Misn Domitila, Santa Ana. Crochet work.

Lornno, Gustaro, "El Poerdenir" mine. Gold, sllver and manganese ores.

Lozano, Calixto \& Benjamin, "Santa Rosa." Gold and gilver ores.

Macay, Philip, "Santa Rowa." Gold and sllver ores.

Madrid, Benjamin, San Salrador. Liquors.

Magana, A., "Chapeltique." Gold and sllver ores.

Mejia, Frederico, "La Labranaa." Coffee.

Melendez, Carlos, "El Angel." Sugar ln blocks.

Melgares, Secundino, “Jocoro." Gold and sllver oreg.

Molina, Juan Antonio, San Salvador. Rubber.

Nolnsco, Panl, "Perquin." Gold ores.

Olmedo, Angel, Santr Ana. Bandore (muslcal inst.).

Parraga, Carlos, San Salvador. Seal case.

Recinos, Fllas, "Perquin." Gold oreg.

Regaldo, Gen. Thomas. Coffee,

Reyes, Francisco A. Penberry colfee.

Roque, Gateben C., "La Union." Mediclnal extracts.

Salicians, Rev. Fathers, Santa Tecla. Tanned sklns.

Serrano, Miguel Antonio, Salrador. Indigo.

Seymour, George W., San Salvador. Pollshed woods.

Soler Bros., "Moraznn." Cigarettes.

Teuncingo, Natives of, Cascatlan. Straw hats.

Ulnarzapn, Natives of, San Miguel. Straw hais.

Velarde, Frederico R., San Salvador. Soaps.

Vilindicencin, Mias Clementina, Sun Salvador. Artlaclal flowers. 


\section{United States Government Buildings.}

DEPARTMENTAL EXHIBITS.

DEPARTMENT OF AGRICULTURE-North Building. Col. J. H. Brigham.

DEPARTMENT OF STATE-East side of Main Building rotunda. Yaj. Wm. H. Michael.

TREASURY DEPARTMENT-West side of Main Building rotunda. Vr. Wallace H. Hills.

WAR DEPARTMENT-East side of Main Building rotunda. Capt. Peter C. Harris.

DEPARTMENT OF JUSTICE-Northeast side of Main Building rotunda. Maj. Frank Strong.

POSTOFFICE DEPARTMENT - Southeast corner of Main Building. Col. John B. Brownlow.

NAVY DEPARTMENT-Southwest side of Mrin Building rotunda. Mr. B. F. Peters.

DEPARTMENT OF THE INTERIOR-Northeast corner of Main Building. Dr. F. W. Clarke.

SMITHSONIAN INSTITUTION AND NATIONAL MUSEUM-Northwest corner of Main Building. Dr. F. W. True.

FISH AND FISHERIES DEPARTMENT-South Building. Mr. W. DeC. Ravenel.

DEPARTMENT OF LABOR-Northeast side of Main Building rotunda. Mr. Chas. H. Verrill.

BUREAU OF AMERICAN REPUBLICS-East side of Main Building rotunda. Mr. Wm. C. Fox.

PHILIPPINE ISLANDS EXHIBIT-North Building. Dr. F. W. True. 


\section{Dairy Building. \\ F. H. Converse, Supt. \\ u. W. Ha11, Asst. Supt.}

The first floor of this building is occupied by the butter and cheese exhibit made in refrigerated cases.

The following States and countries have sent exhibits of dairy products:

Iowa.

MInnesota.

Nebraska.

Callfornla.

Missourl.

Canada.

North Carollna.

Penusylvania.

North Dakota.
New York.

Connectlcut.

New Hampshlre.

Massachusetts.

New Jersey.

Ohlo.

Michigan.

Wisconsin.

IIIInols.

\section{EXHIBITORS.}

Brungwick Refrigerating Co., New Brunswlck, N. J.

Continental Creamery Co., Topeka, Kansas.

Cochran Refrigerating Co., Lorraine, $O$.

De Laval Separator, 74 Cortlandt St., New York, N. Y.

The De Laval cream separators are of the Improved "Alpha" disc type and are as much superlor to other separators as such machlnes are to gravity settlug methods.

Gem Package Co., Detroit, Mich. Good Luck Creamery Co., 183 s. Water St., Chicago, III.

Heller and Merz, f5 Maiden Lane, New York, N. Y. Butter color.

Iron Clad Mig. Co., 2-4-6 Clifi St., New York, N. Y. Cans and dalry supplles.

Minnesota, State of, "The Bread and Butter State." Model in butter.

This is the largest model ever made of butter. An exact reproduction of the new Capitol; weight 1600 -lbs. pure creamery butter. In the largest glass refrigerator ever made.

Oakes and Burger, Cattaraugus, N. Y. Cheese and butter factory suppiles.

Reed, A. H., 30th Market Sts., Phlladelpbla, Pa. Cream separator and pasteurizer.
Sharples, P. M., West Chester, Pa. Tubuiar cream separators and supplles. New tubular suspended bowl, bottom feed cream separators. Improve. ment over the disc or old style bowls with contraptions inside. Squeezer combined churn and butter worker. Squeezes Instead of grinding. Dairy and creamery appliances.

Star Milk Cooler Co., Haddonfleld N. J. Milk aerators.

Vermont Farm Machine Co., Bellows Falls, Vt. Separators and dairy apparatus. Improved $U$. S. cream separators and other dalry and cream. ery supplles.

\section{CALIFORNIA.}

Bonanza Cream Co. Canned cream butter.

Eagle Dairy Co. Canned butter. Golden Poppy Co. Crinned butter. Golden Poppy Co. Canned crenm butter.

Lily Cream Co. Canned cream butter.

Norton, Tellier \& Boden. Canned butter.

Russell Crcamery Co. Canned cream butter.

Schnty-Mnrtinelli \& Co. Canned butter.

Whituey \& Co., C., San Franciveo, Cal. Canned butter. 


\title{
Model Dairy.
}

\author{
F. H. Converse, Supt.
}

Edwand Van Alstyne, Asst. Supt.

In this department is conducted a complete working dairy during the six months of the Exposition. Five cows selected from ten different breeds compose the dairy. Daily demonstrations of separating, churning, testing, etc., are carried on between the hours of 8 and 12. Accurate records of the daily performance of each cow are kept, showing the cost of production of milk and butter.

The stable is equipped with all modern appliances, special attention being given to hygienic and sanitary conditions. All the milk and buttermilk produced daily from the 50 cows in this dairy is served to visitors.

\section{THE ENTRY LIST IS AS FOLLOWS.}

\section{UNITED STATES.}

American Deronshlre Cattle Assoclation. dmerican Guernsey Cattic Club. American Polled Jersey Ciub. Ayrshire Brecders' Association. Brown Swiss Breeders' Association. Dutch Beited Cattle Breeders' Associatlon.

Red Polled Cattle Club of America.

\section{CANADA.}

Canadian Ayrshire Breeders' Association.

Canadian Jersey Cattle Association.

Canadian Holsteln Freisien Assoclation.

Dominion Short Horn Breeders' Association.

French-Canadian Cattle Breeders' Assoclation.

\section{Live Stock Pavilion-A.}

Allen Sheep Sherring Co,, Chicago, Ill. Shearing machines.

Anti-Cholexa Co., Chicngo, 11. Mediclnes.

Cornell Iucubntor Mig. Co., Itha$\mathrm{ca}, \mathrm{N}$. $\mathrm{Y}$. Incubators

Cyphers Inculutor Co., Wayland, N. Y. Incubators.

Holt, 1. W., Rose Hill, N. Y. Antomatic check.
Inailla Incubator Co., Rose Hill. N. Y. Incubators.

Prge, C. H., Bufalo, N. Y. Door guide and stay.

Poultry Food, Geo. $u$. Harding, Blnghamton, N. Y.

Pumplirey \& Co.. W. M., IndtanapoIIs, Ind. Feed boxes. 


\section{Bazaar Bailding.}

\section{EXHIBITORS.}

Adam, Meldram \& Anderson Co., Buffalo. Fancy goods.

Aishton, G. F., Rochester, N. Y. Toy tops.

American Express Co., Brffalo, $\mathbb{F}$. $\mathbf{Y}$.

Anicrican Sonvenir Co., Buffalo. Souvenlrs.

Arnold, C. D., Bufferlo. Photographs.

Austin \& Crav, Sonth Norvalk, Conn. Collar buttons.

Beans, G., Philadelphia. Pencll Sharpeners.

Bergman, Mrs. Thekla, Chtengo. Noveltles.

Bistany, Khalll A., Bufialo, Imltatlon turquolse and matrly Jewelry.

Buedingen Mig. Company, Rochester, N. Y. Purzles.

Buffalo Concessions Co., Buffalo, Soft drinks.

Bufialo Sour Pepsin Gum Co. Chewing Gum.

Buzracott Clock Co., H. \& R., Chicago, Ill. Halr clasps.

Byrne, John, Jr., Bufalo. Souvenlrs.

Callaway, A. B., Buffalo. Old stono jewelry and burnt leather.

Chessman, O. S., Allegheny, Pa. Jewelry.

Chouffet, C. M., Bufinlo, N. Y. Ofinclal souvenlr clocks.

Clark, D. S., Buffalo, N. Y. Games.

Clans Shear Co., Fremont, Ohio. Cutlery.

Cullen, I. P., New Albany, Indiana. Jewelry.

Diefenbach, Wm., 690 Northampton St., Bufralo, N. $Y$. Rellglous goods.

Doran, W. J., Bnffalo. Paper welglits.

Dugan, F. J., S. Norwalk, Conin. Carved and burnt leather.

Fantani, G., 394 Genesee St., Bnlfalo, N. Y. Embroldery.

Fisher, The A. D. Co., Toronto. Souvenlrs.

Fleischman, Joseph, 26th 12th St., New York City. Growing vases.
Flosg, John G., Buffalo. Jewelry.

Foo Pan Key, Exposition Grounds. Chlnese goods.

Frnscolla, C., Lnkewood, N. J. Danlsh goods.

Frebe, Christian, Philadelphia. Wood carving.

Gem Cntlery Co., Fer Tork. Safety razors.

Goldman, J., Bunalo. Metal goods.

Gondolf, C. F., Bufinio. Spool supporters.

Grossman, H., St. Angustine, Fla. Leather goods.

HaIl, Wilbur F, Merlden, Conn. Sllver goods.

Hatharvay, W1ck, Madison, Ohlo. Wire nall goods.

Heyman, E., Buflalo, N. Y. Amber goods.

Holladay, Benton \& Co., Chicago, III. Shoe dresslng.

Hollister, Mrs. I., Fnrtford, Conn. Tollet preparations.

Hornstein, Leo, Buffalo. Anstrlan goods.

Hony, Philip H. C., Sr., Buflalo, Jewelry.

Houzlg, Mrs. Leopoldine, Buflalo. Jewelry, etc.

Indian Congress, S. Midway. Indlan goods.

Japanese Village Co., Bufialo, $N$. Y. Japanese goods.

Joham, Joseph, Chtcago. Seaslde goods.

Johnmon Co., G. T., New Xork. Glove and cloth cleaner, hold-a-coler, pleaters.

Klft \& Co., Jos., Philadelphia, Pa. Fancy vases.

Kimsey, J. C., Philadelphia, Pa. Long walst former.

Lewis \& Dugnn, 396 Broadray, N. Y. Porto RIcan goods.

Lowrie, Mrs. Wilhelminn, Buffalo. Walst adjuster.

Lucas, Geo. F., Allegheny, Pa. Sharpenlng stones. 
Lackey, Mrs. A., Bufalo. Filagree.

Mackmoud, Elias New York. KImonos.

yanu \& Co., C. A., Buffalo, N. Y. Holdfast gcrew-drlver.

Wathes, Kirke B., Buffalo, N. Y. Shell goods.

Metzger, Mark, Denver, Colo. Agates and curlos.

Moffett, S. C., New York. Imperial cement.

Moser, O., Buffalo. Bronze goods. Irnyon's Remedy Co., N. Y. Soap. Nasr, N., Buffalo. Fans.

National Express Co., Buffalo, N. $x$.

Ningara Envelope Co. Stationery.

Nicolai, Robert J. H., Bufialo. Blsque noveltles.

New England Stamp Co., Boston, Mass. Stamps.

New Jersey Aluminum Co. (Ampere Noveity Co.), Newark, N. J. Aluminum noveltles.

N. Y. Improrement \& Mfg. Co., New York, N. Y. Waxlng pads.

Norton, Nathnniel W., Buffalo. Cards.

odorheart Perfume Company, Cleveland, Ohlo. Perfume.

olney Mfg. Co., Pittsfleld, Mass. Manufacturlng machinists, makers of the Olney alr englnes for power and transmlsslon, the "Vlrtuoso" plano player and sclentiflc noveities, models. experimental work, all klnds. toy englnes.

Palmerl, Frank T., Brooklyn, N. Y. Jewelry.

Pan-American Badge nnd Sonvealr Co., Buffalo, N. Y. Badges, etc.

Pan-Ameriean Candy Co., Buffalo, N. Y.

Pan-American Crne nnd Plpe Co., Buffalo. Canes and plpes.

Pan-Americnn IRy. E S. S. Information Bureau.

Pease, C. G. \& M. S., Painesville, Ohlo. Wood sourenlrs.
Postal Telegruph Co.

Powers, Lee L., Boston, Mass. Antlque furnlture.

Reynolds, F. G., Bufalo. Sharpenlng stones.

Robnson, Lnzare A. R., San Franclsco, Cal. Russlan goods.

Rosezalia Mig. Co., Sycamore, III. Tollet preparatlons.

Hussia Cement Co., Gloucenter, Mass. Glue.

Saldy, J., Buffalo. French goods.

Sall, Achille, Oriental viliage. Postage stamps, etc.

Slinn, Lulu M., Bufralo. Engraved goods.

Sonora Newn Company, Expositlon Grounds. Mexican goods.

Steplrenson \& Co., New York, N. Y. Sklrt supporters. Don't fall to see the All-Ways ready sklrt supporter demonstrated ln Bazar Bullding. Stephenson \& Co., manufacturers, New York. Agents ail over the world.

Sovins Novelty Co., Buffalo. Swisa goods.

Sylvester, Thos. Wood and pearl noveltles.

Tator, Arthur R., Brookiyn. Rubber and chenllle noveltles.

United States Express Co., Buffalo, N. Y.

Wagner nifg. Co., New York. Tortoise shell goods.

Walker, Mrs. J. A. Fllgree nov, eltles.

Weller of Further, Huffalo. Sheet muslc.

Welle, Fargo Express Co., Bufalo, N. Y.

Western Union Telegraph Company.

Wheelcr, G. A., New York. Topw.

Williams, Miss, \& Wasliburn, Mrs., 112 ucst St., Buffalo, N. Y. Souvenirs.

Wizard Novelty Co., Phlladelphin, Pa. Tops.

Young, Alpheus \& Son. Wire jewelry.

zitoun, Mrs. M., Oriental Vulage. Orlental goods. 
The Pan-American Official Catalogue and Guide. M E M O R A N D A. 
The Pan-American Official Calalogue and Guide.

\section{FRON THE INDIAN CONGRESS}

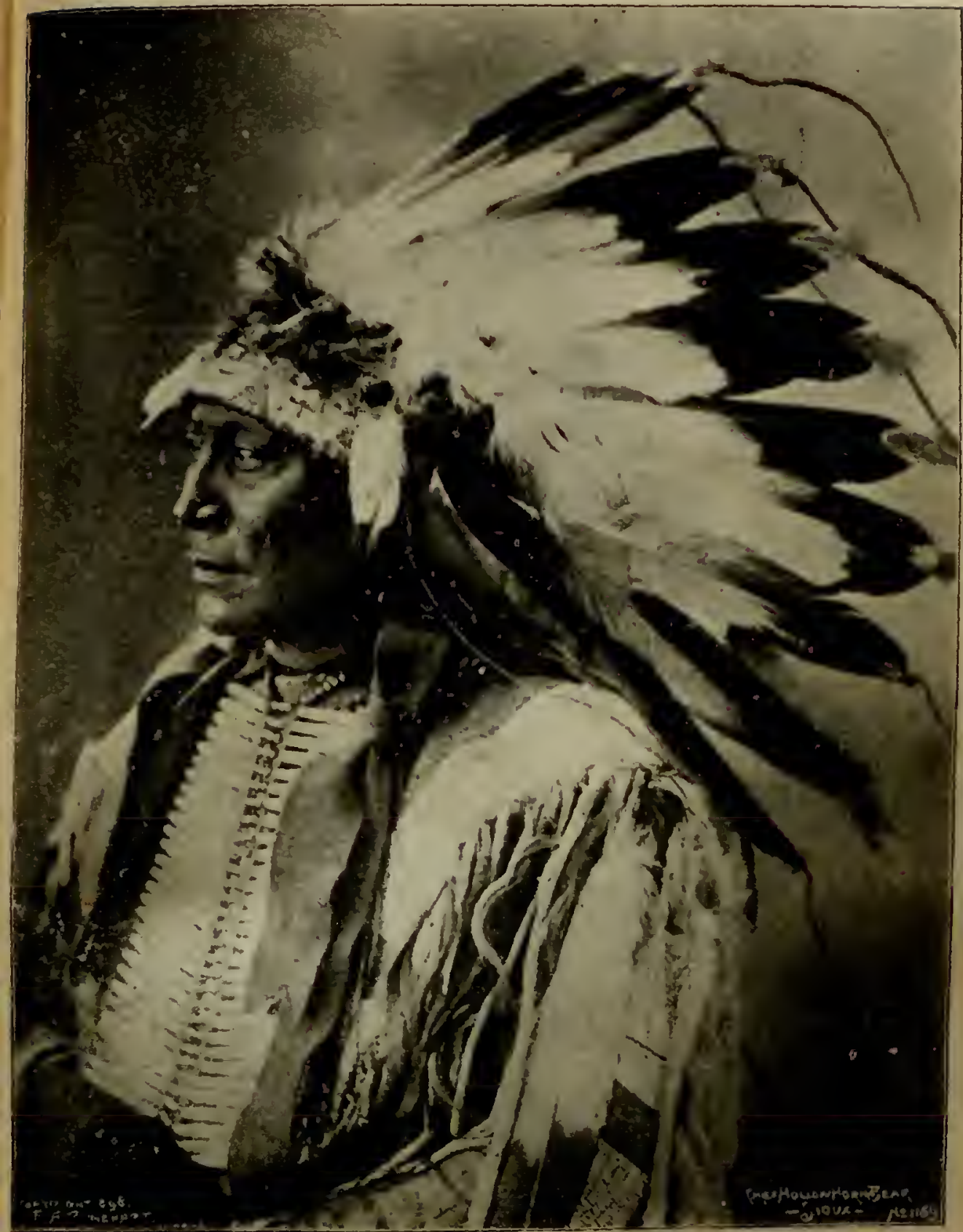

Chlef Hollow-Morn-Bear 
The Pan-American Official Catalogue and Guide.

\section{IN THE EBQUIMAU VILLAGE}

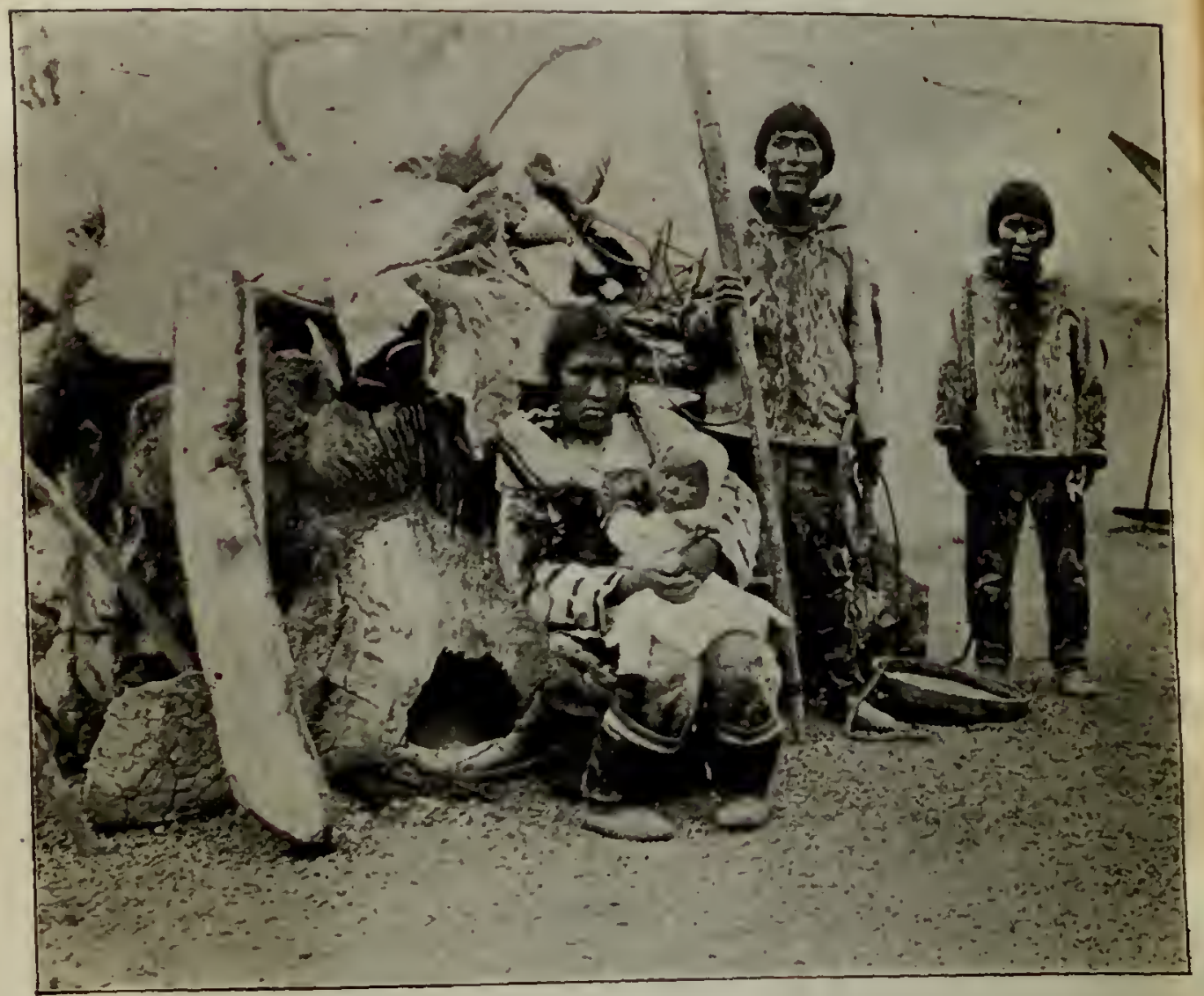

"Interrupted" 
The Pan-American Offcial Catalogue and Guide.

\section{IN THE ISQUIMAU VILILAGE}

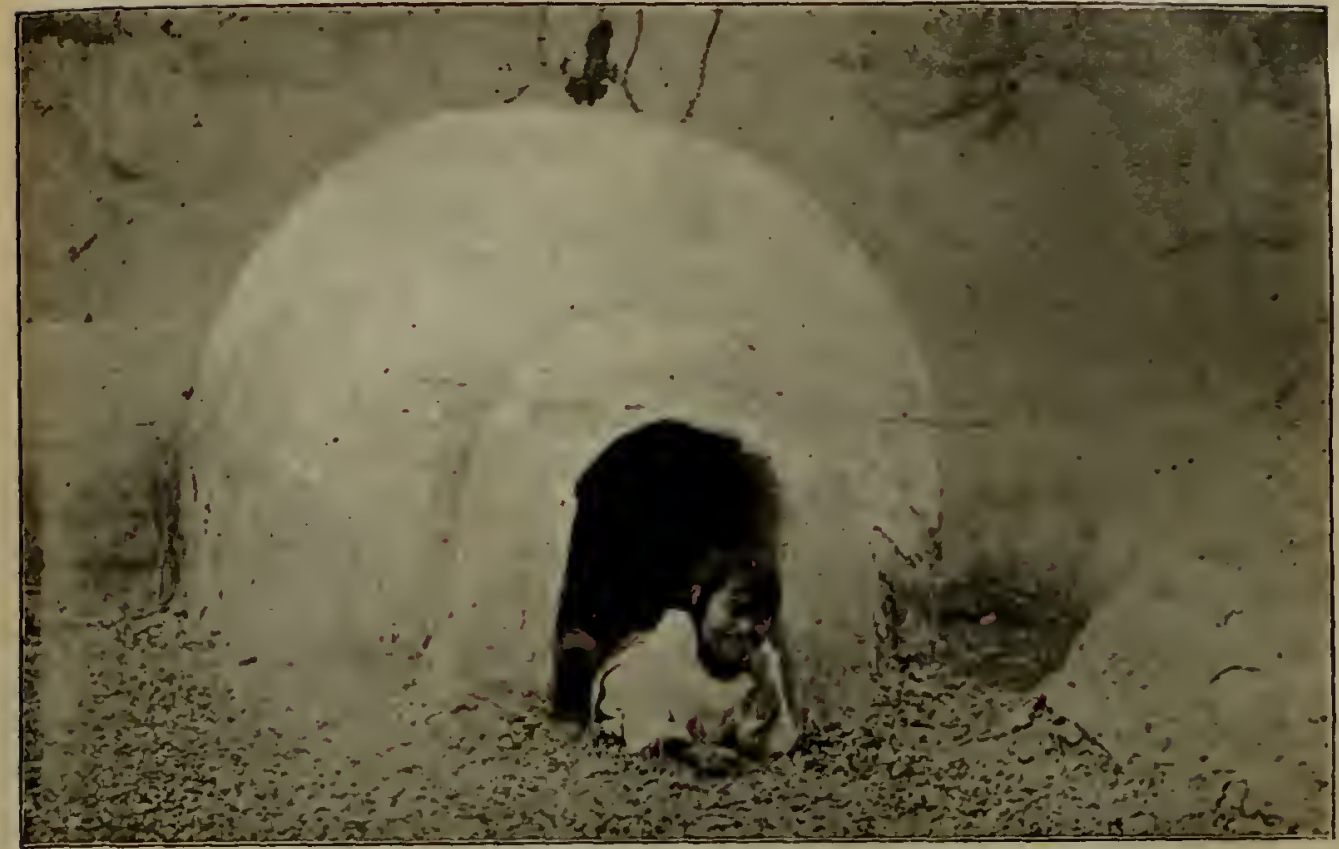

"Hello"

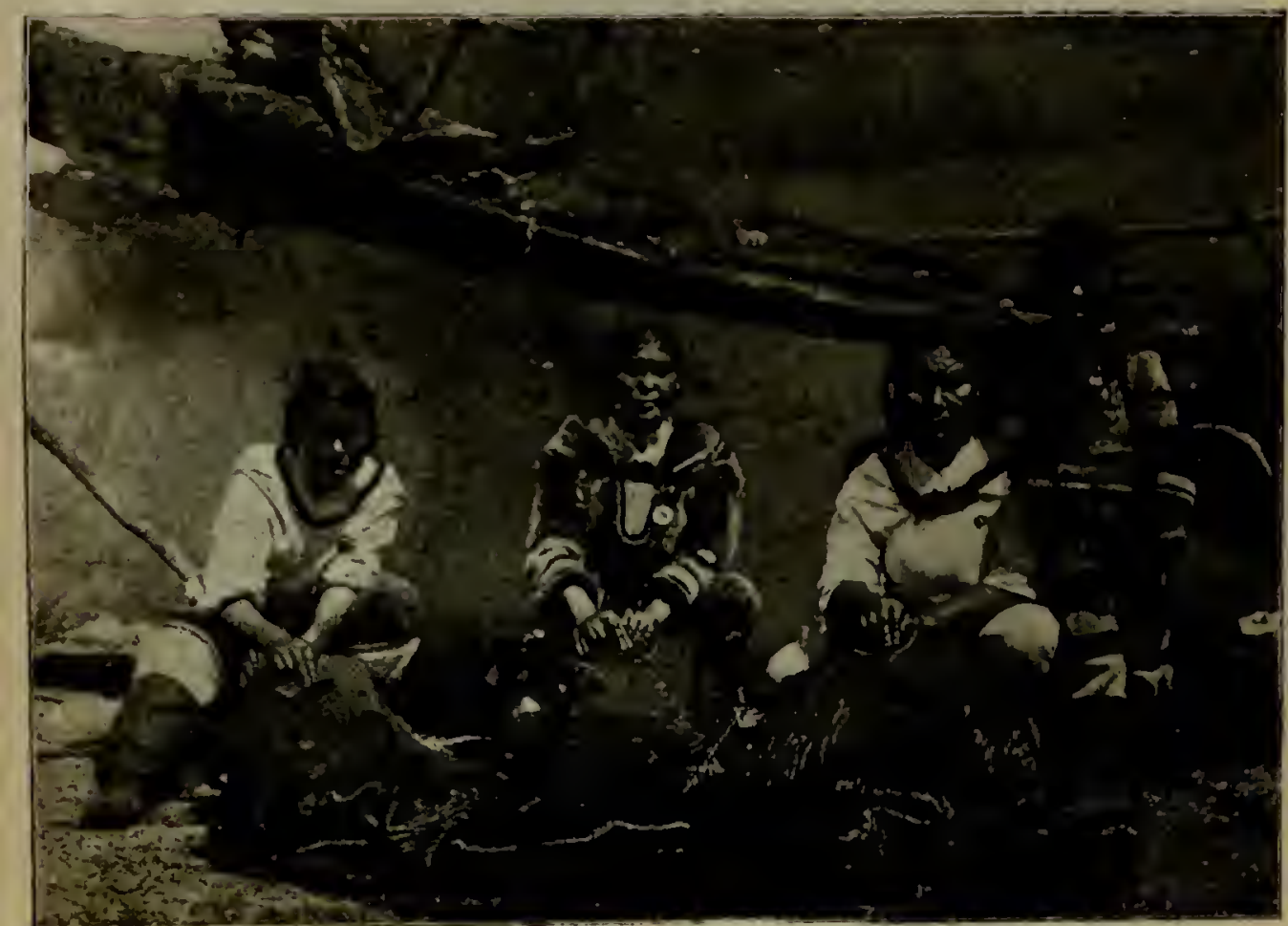


IN "DARIEEST AFRICA"

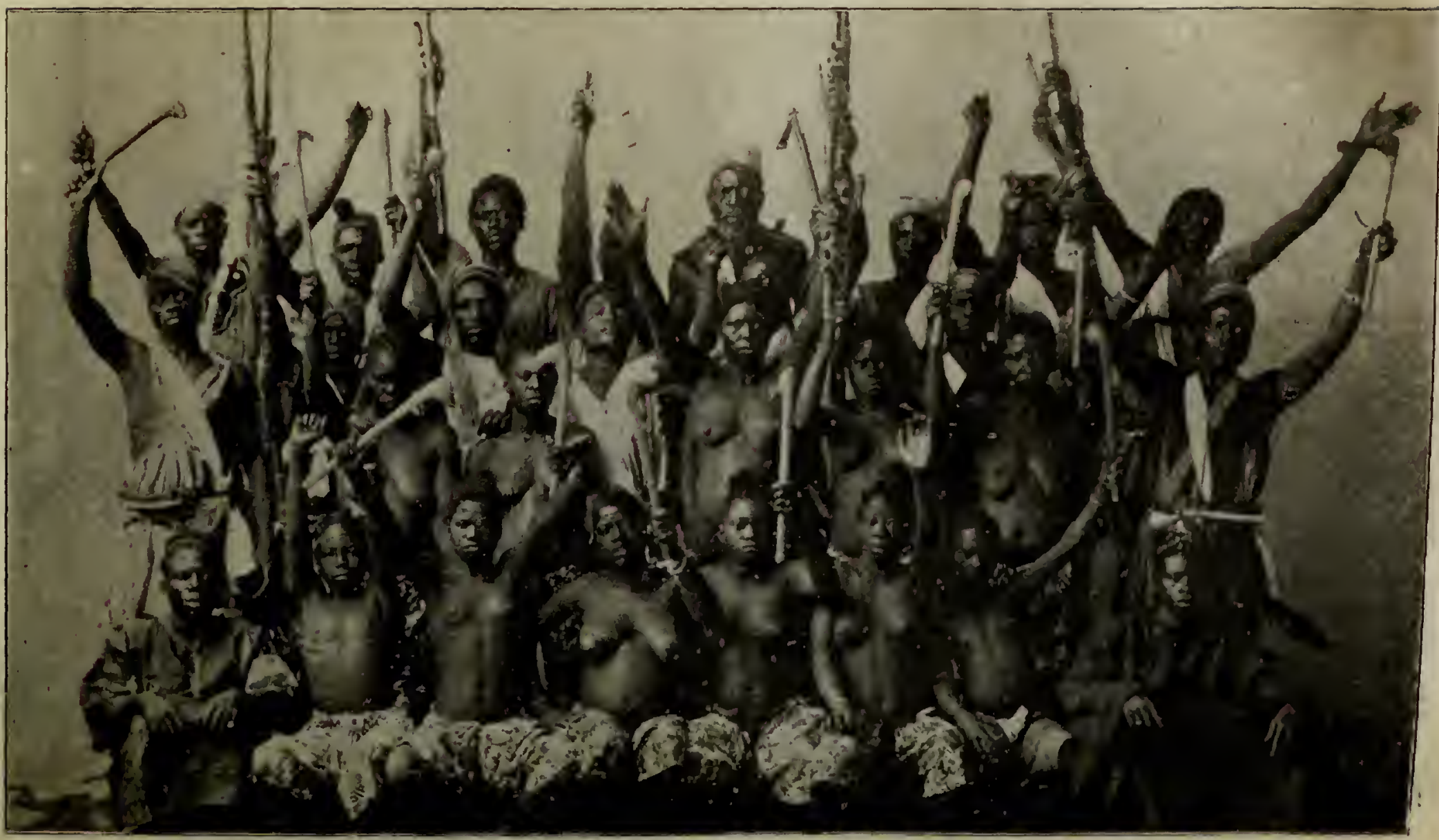

בิ

One of the Canuibal Tribes 
IN THE INDIAN CONGRESS

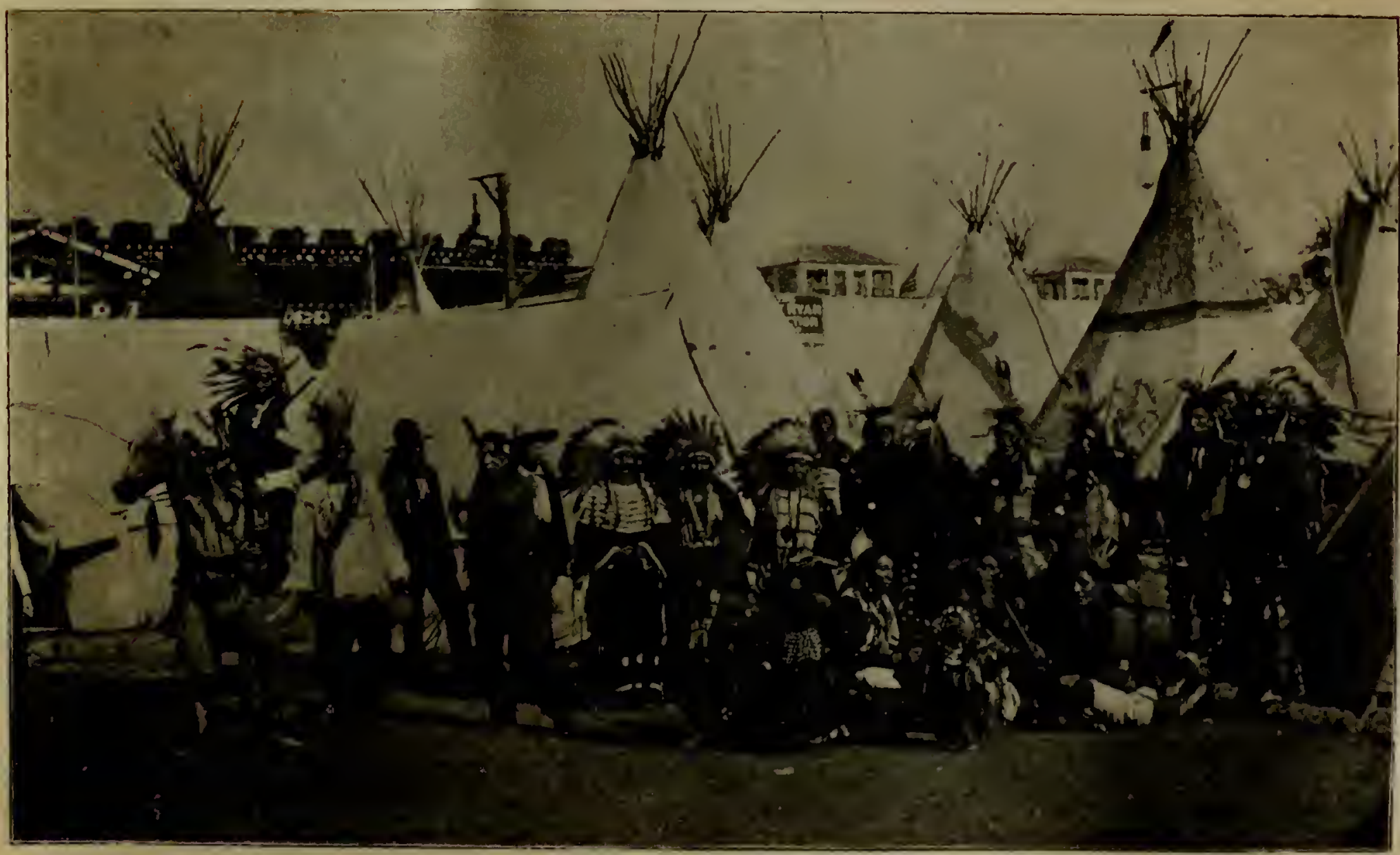

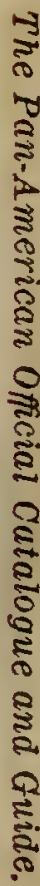


IN A "TRIP TO THE MOON"

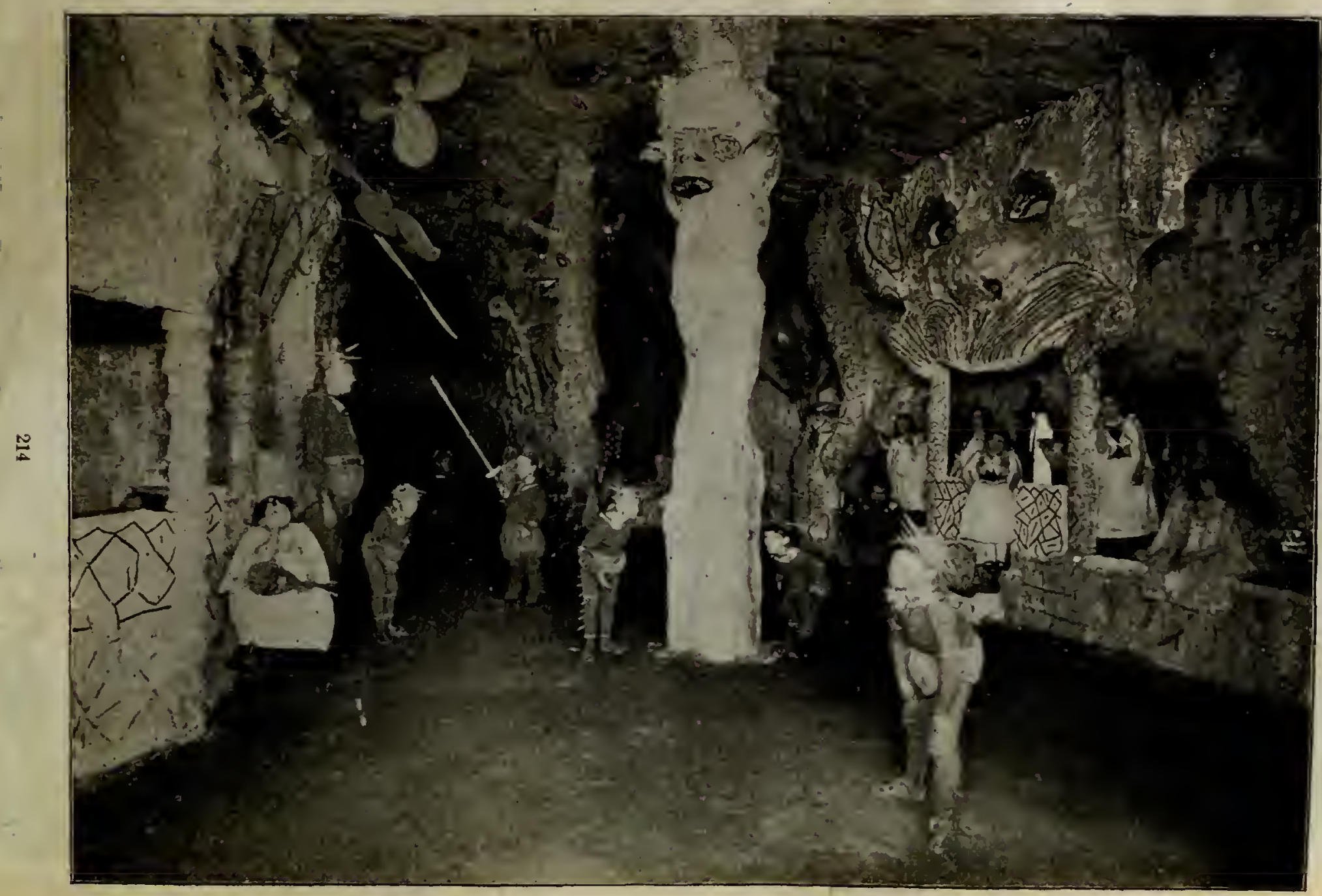

है 
The Pan-American Official Catalogue and Guide.
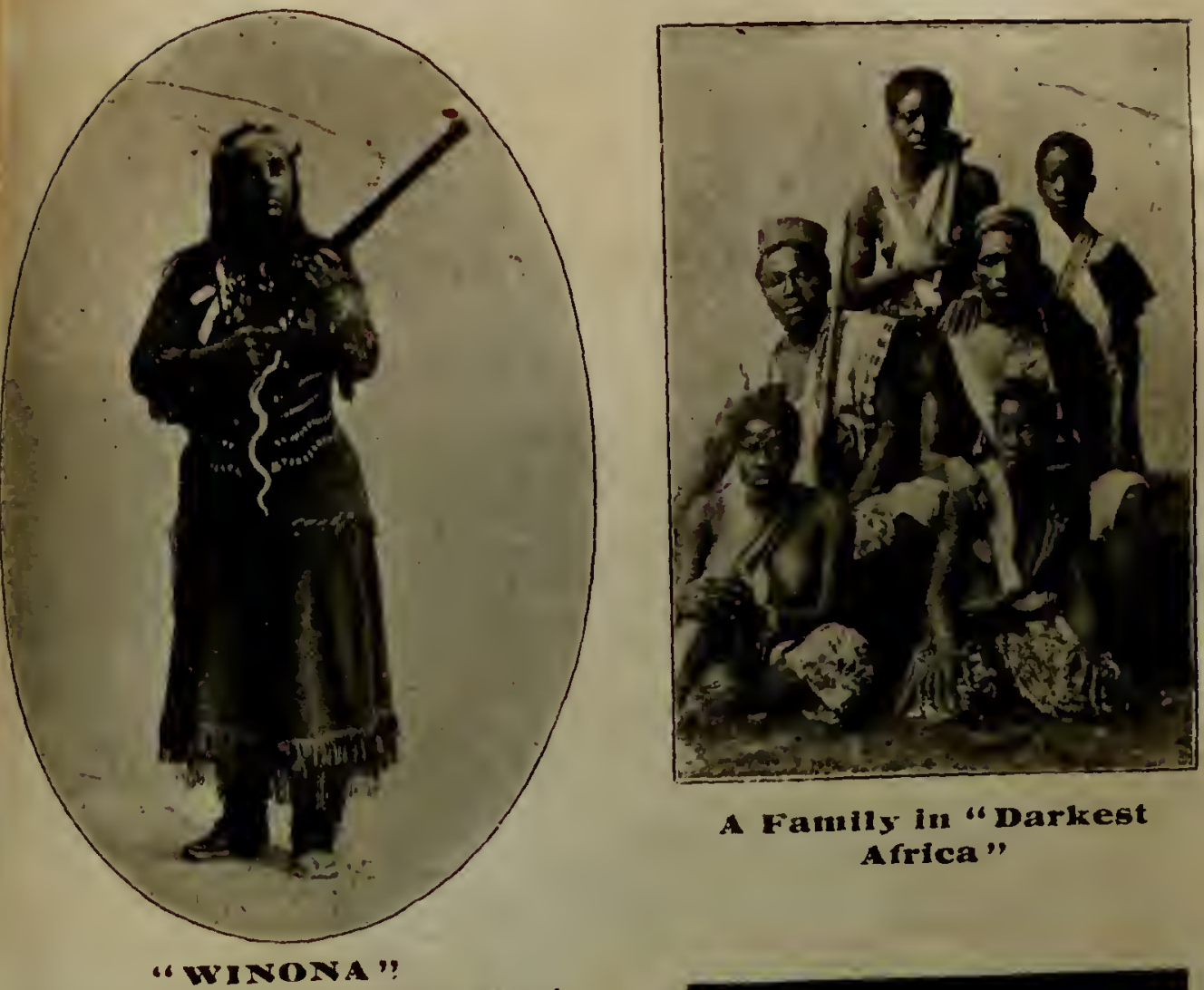

A Family in "Darkest Africa"

World's Crampion rifle shot, in the Indian Congress
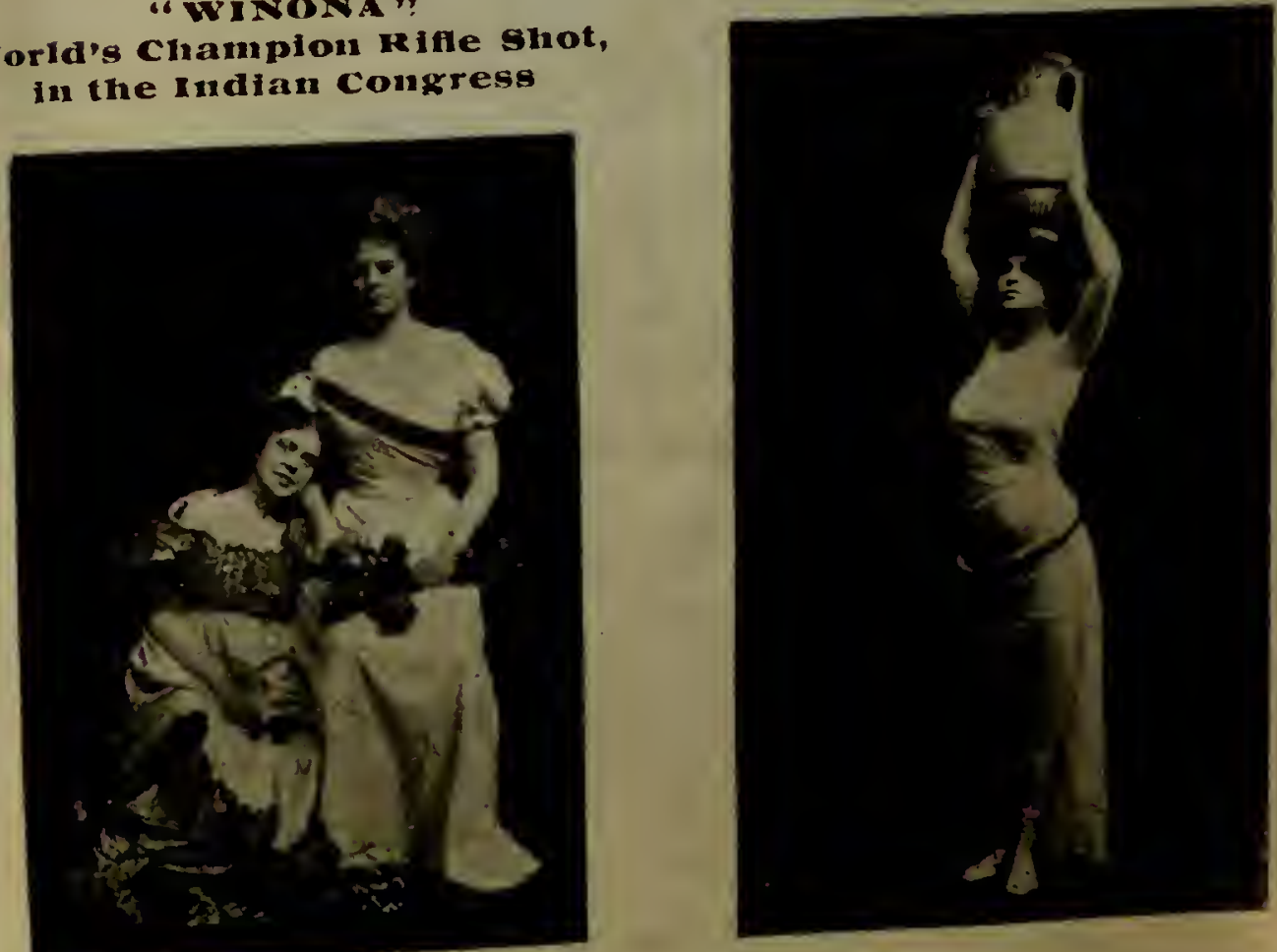

Artists in "Around the World" 
The Pan-American Official Catalogue and Guide.

\section{IN THE INFANT INCUBATORS}

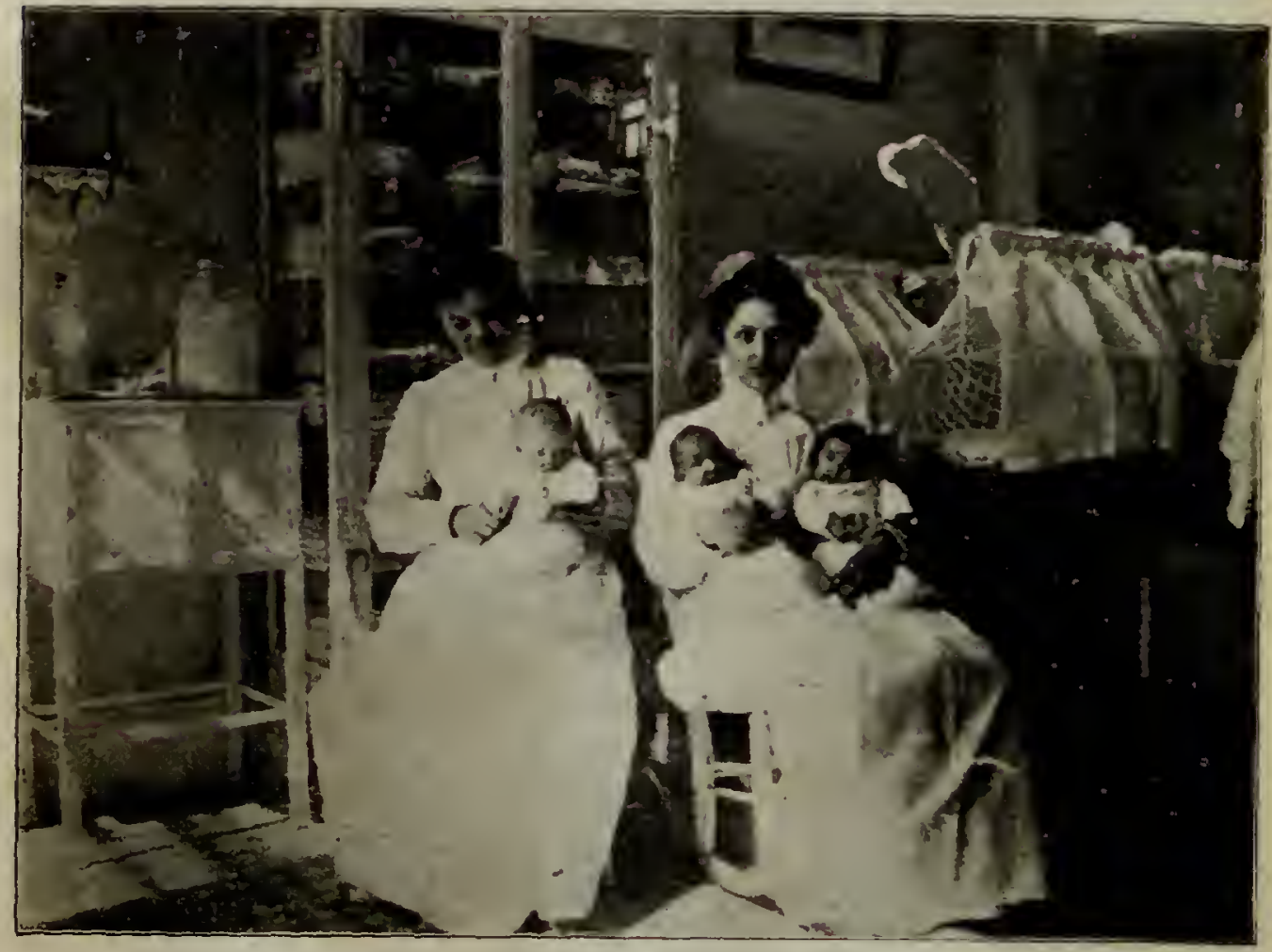

"Three Graduates" 
The Pan-American Official Catalogue and Guide.

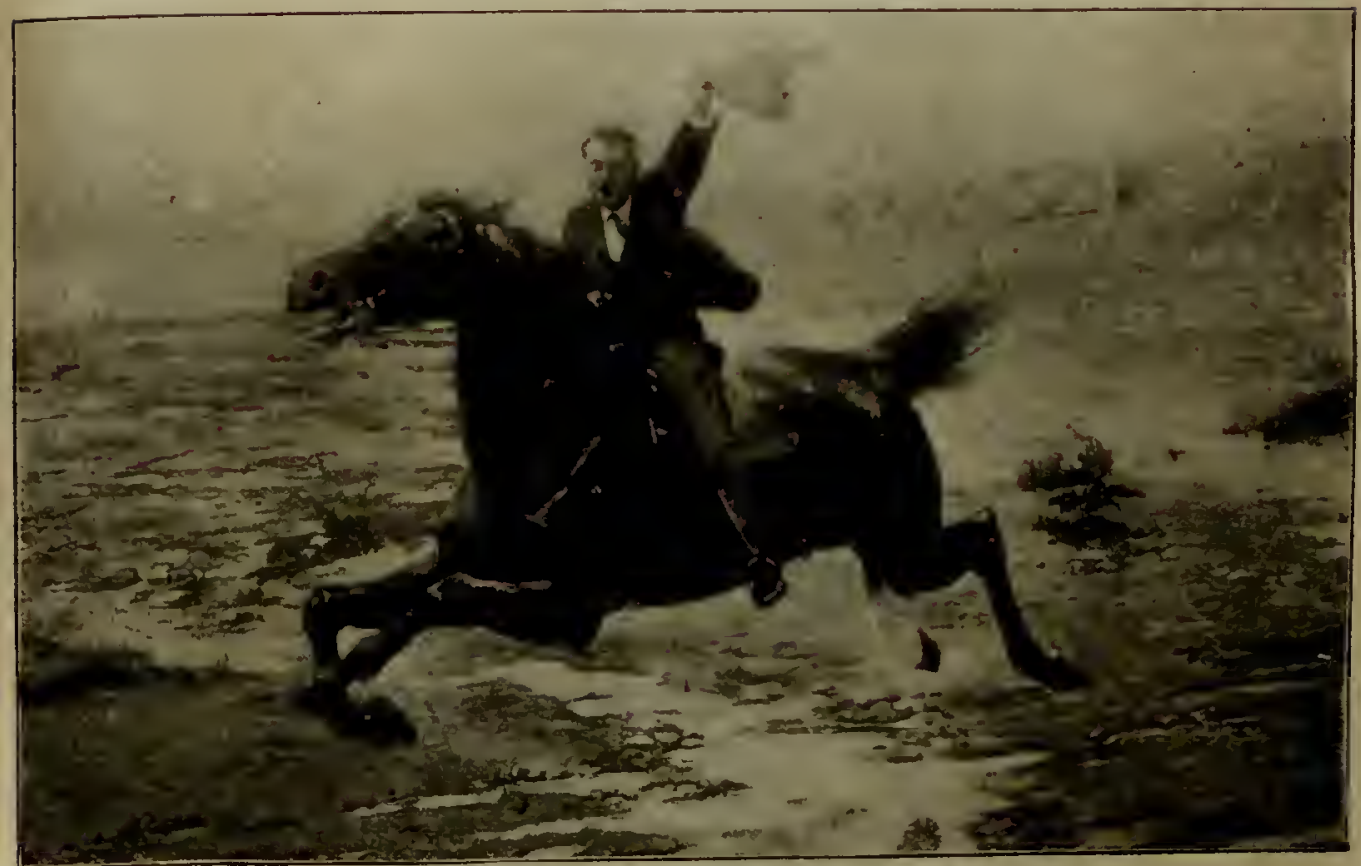

\section{JOMN BAKER}

the hero of "The Johnstown Flood" 
IN HOSTOCK'S ANIMAL ARENA

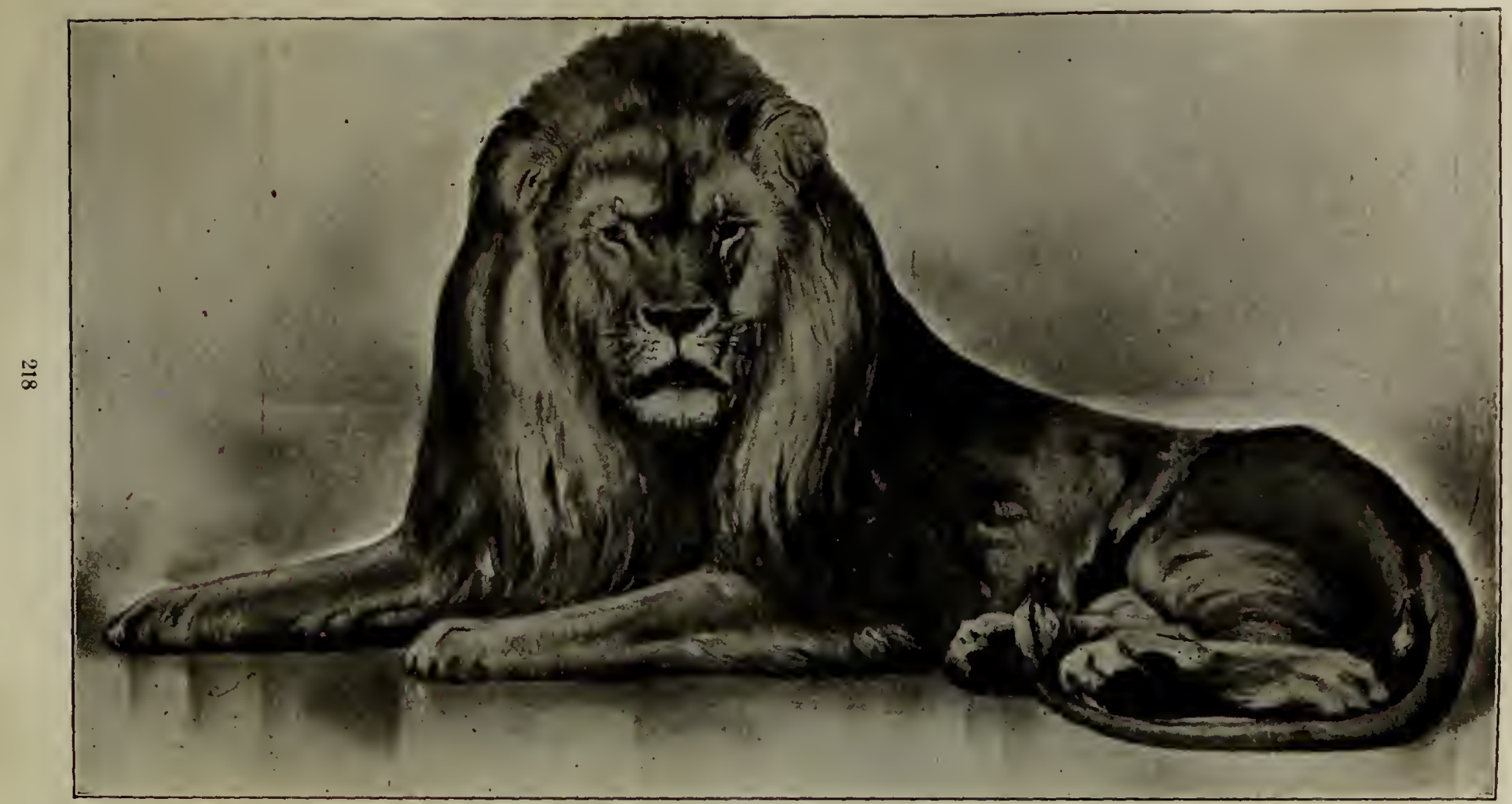


The Pan-American Official Catalogue and Guide.

\section{IN DARKNEBS AND DAWN}

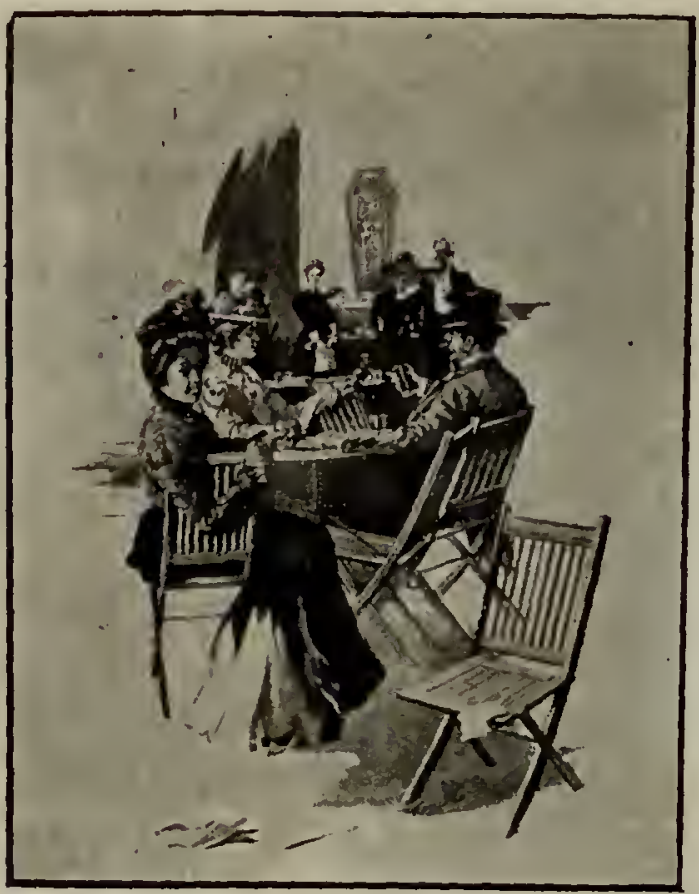

In the Cafe of the Dead

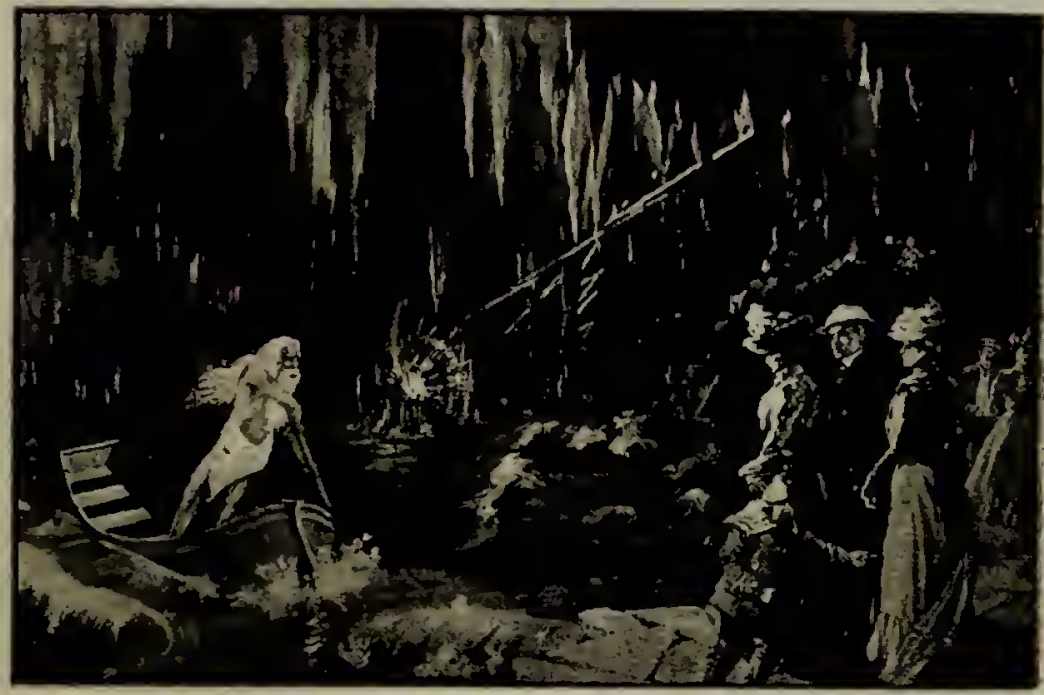

Sliaron 
The Pan-American Official Catalogue and Guide.

THE LAND OF THF MIDNIGHT SUN

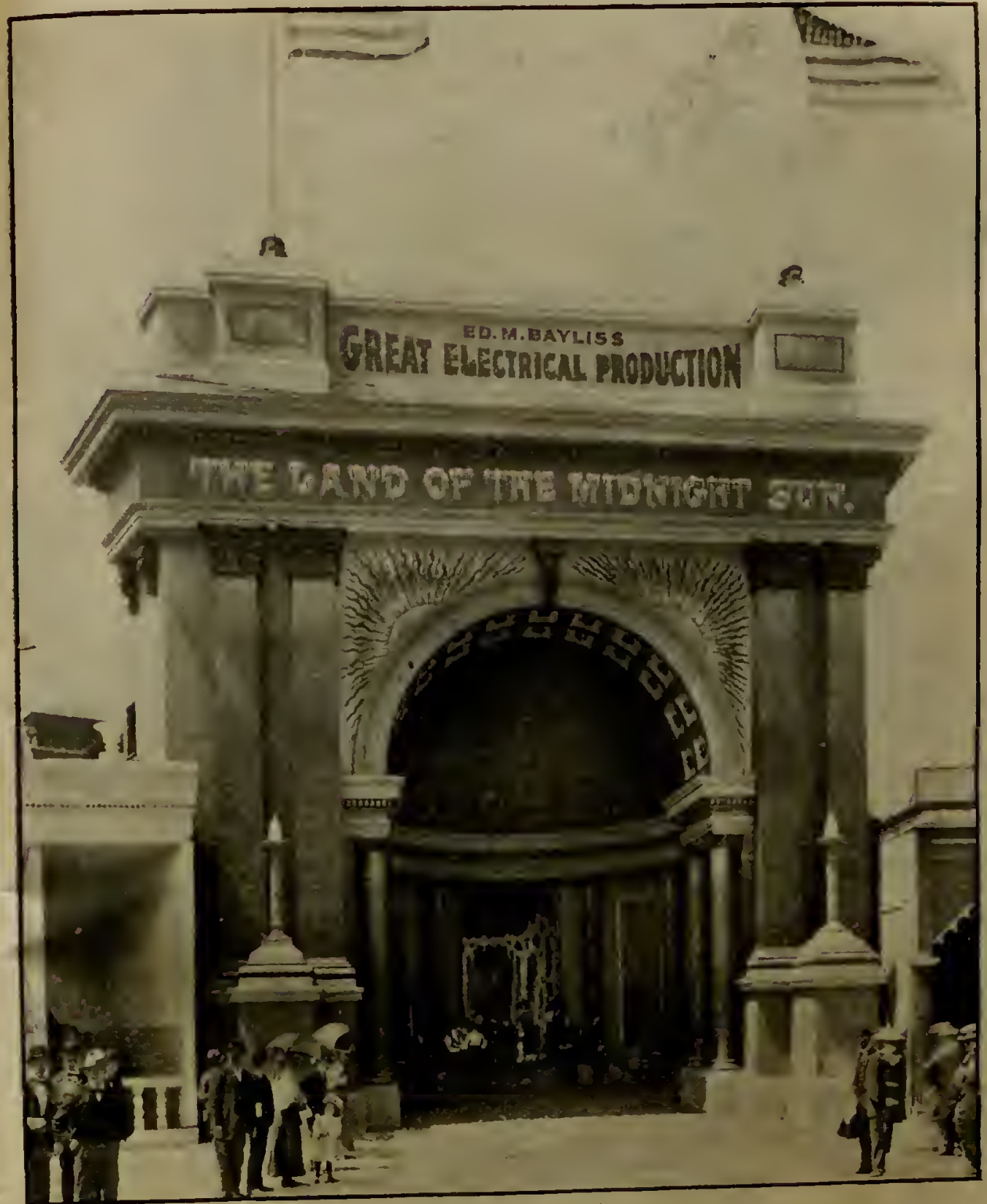


The Pan-American Official Catalogue and Guide.

\section{THE MOORISH PALACE}
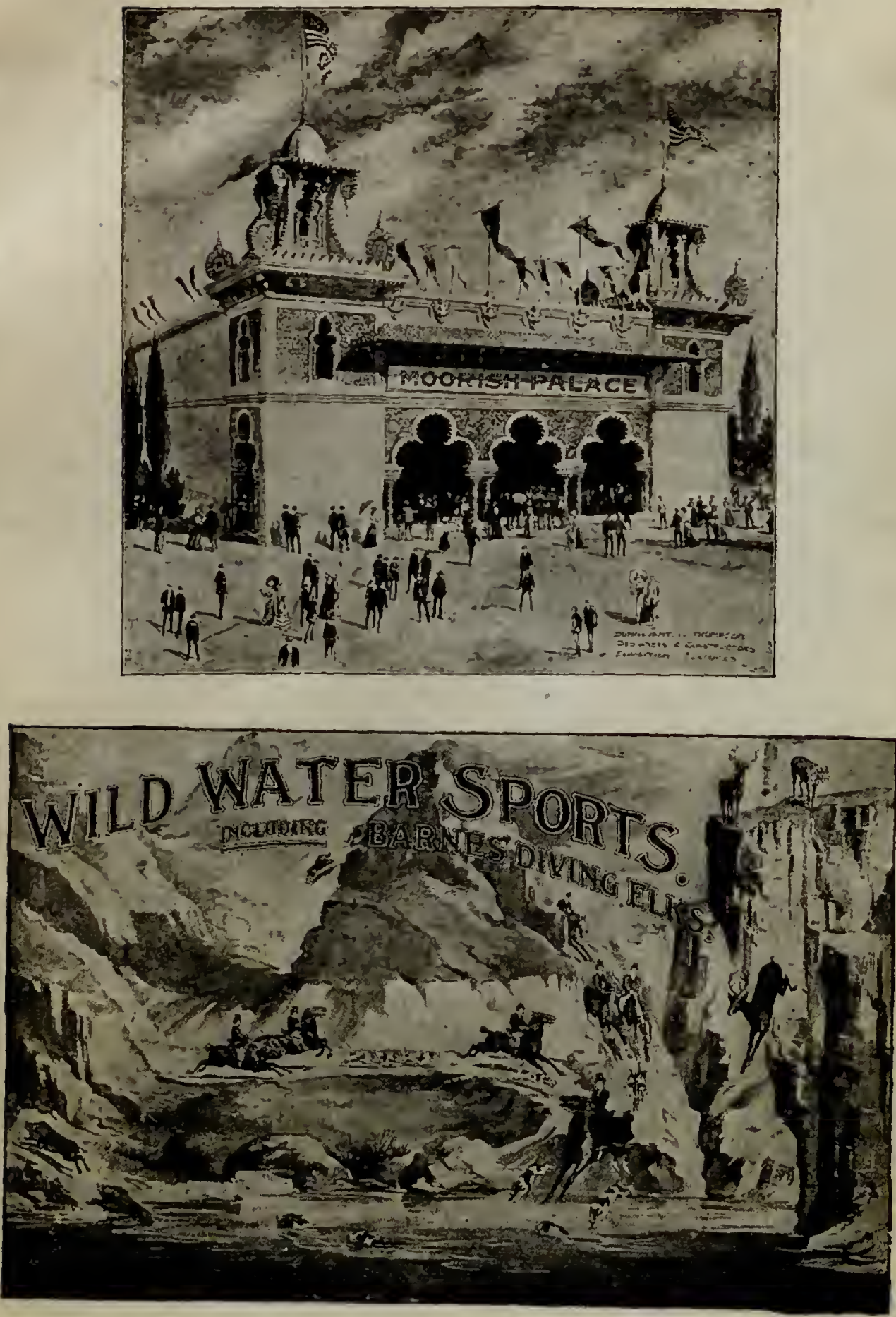
The Pan-American Official Catalogue and Guide.

\section{IN AKOUN'S BEAUTIFUL ORIENT}

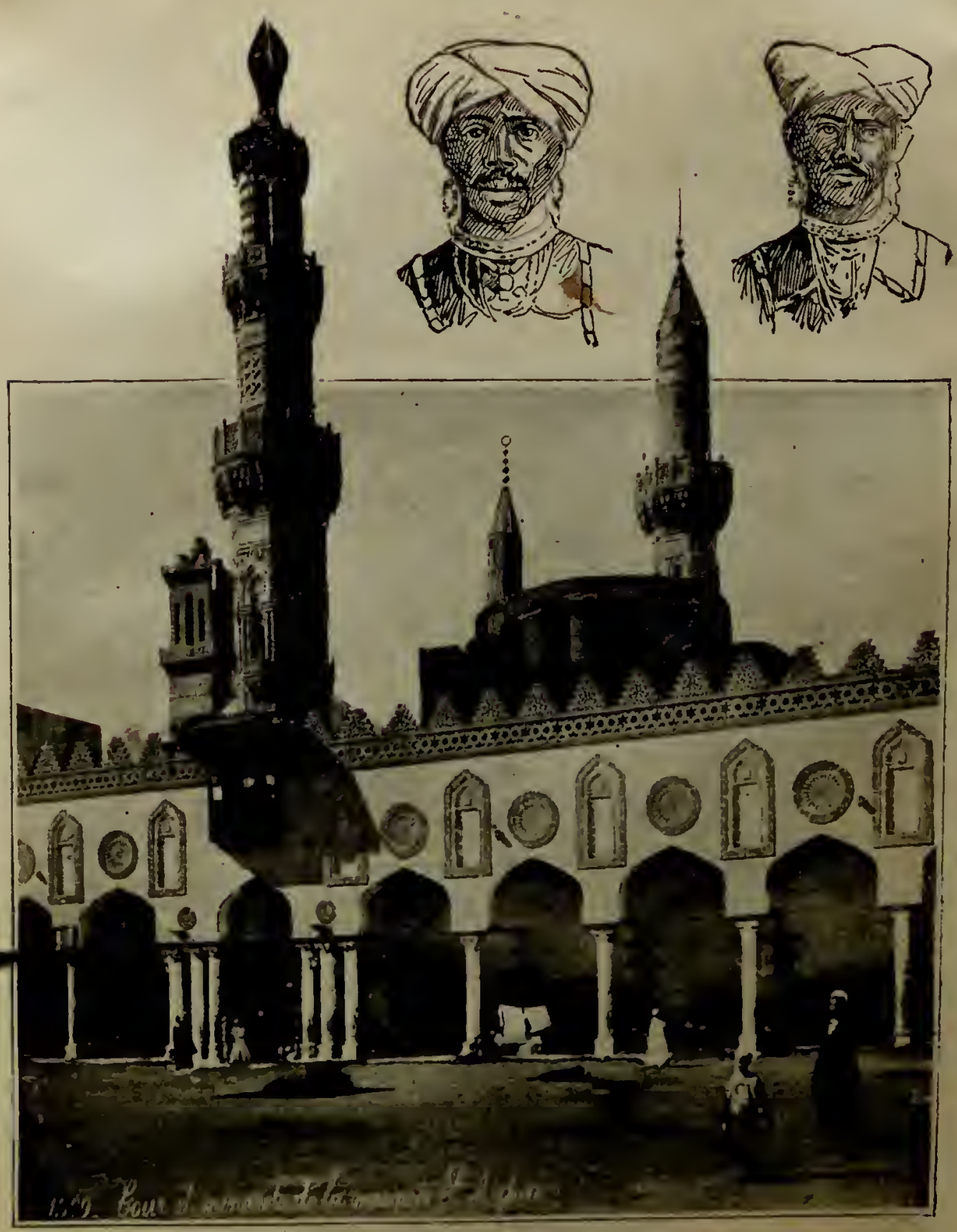




\section{INDEX.}

\section{GUIDE.}

PAGE.

Acetylene Building .........

Agriculture Builang ........ . . . . 22

Alaska Building .......... by

A. O. U. W. Building............. 39

Armories..................... 89

Art Buslding............... $2 y$

Baker Building ........... . . . 39

Banks .............. d o

Bazaar Building ................ 34

Bullalo's History . . . . . . . . 72

Bulldings, rublic ......... ss

Cancera t'rivileges ............ 40

Cauada Building . . . . . . . . . 31

Lhsulauqua ............ 69

churches .............. 89

Concessions .............. . . . . 94

Culor silieme . . . . . . . . . . 13

Committees of Exposition ...... b

Collventions ............ 65

Dairy Building . . . . . . 34

Virectors of Exposition ....... 6

Jrakc Building ............... 40

Electricity Bunlding . . . . . . . . 18

Electric fower ........... 17

Entrauces ........... 15

Ethuology Buildiug ......... . . . .

Exposition, The ........... 11

Foreign Countries Buildiugs . . . . . 30

Forestry Building ............... 35

Gondola Routes.............. 3s

Grange Building. . . . . . : 37

Grand Callal

Graphic d rts Building. . . . . . . 26

Graphic Arts Workshop : . . . . . 26

Hack Ordiunce

Horticulture Building ......... . .

Horticultural Gardens. . . . . 35

Hospital Building .......... 35

Hotels .................. 84

llumiliation $\ldots$

Inscriptions of the Exposition . . . . . 55

Indian Monnds . . . . . . . 68

Latin-A merican Countries. . . . : 31

Live Stock Buildings $\quad$ PAGE.

Lowney Building ........ . 37

Machiuery and Transportation Buiding 39

Manufactures and Liberal Arts Building 21

Mraccabees Building . . . . . . 39

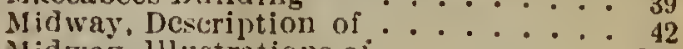

Nidway, llustrations oi ........ 209

Mines Bnilding . . . . . . . . 2025

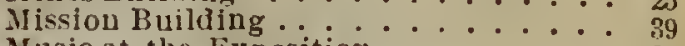

Nusic at the Exposition . . . . . . 57

Mnskoka luakes .............. 71

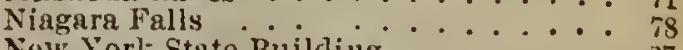

New York State Building . . . . . 27

Officers of Exposition $\ldots \ldots \ldots$

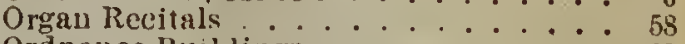

Ordnance Buildings

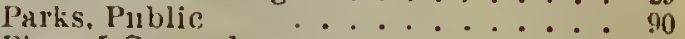

Plan of Grounds. . . . . . . . 11

Plaza . . . . . . . . . 17

Press Buildiug . . . . . . . . . . . 37

R. R. Jepots

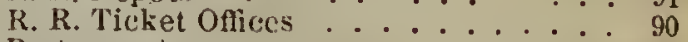

Restau rants . . . . . . . . . . 38

Rose Gardens . . . . . . . . . . . 35

Sculpture .................. 41

Service Building

Side Trips from Bumalo $: \ldots . . \quad \ldots 69$

Six Nations Exhibit . . . . . . . . 35

Special Days . . . . . . . . . f

Sport Days . . . . . . . . . 61

Stadium . . . . . . . . . . 27

Stamps, Pan-A meriean Series . . . 40

Standard Paint Co. Building . . . . . 40

State Buildings . . . . . . . . 30

Steamer Wharves $\ldots . . .2 . . .990$

Strect Car lines . . . . . . . . . . 92

Telegraph nftices......... 88

Temple of Musir. . . . . . . 25

Thousand Islands . . . . . . . . 70

Thenters . . . . . . . 77

Triumphal Bridge . . . . . . 15

U. S. Goverument Buildings $\quad \ldots \quad \ldots 18$

Women's Building. . . . . . . . 26

\section{CATALOGUE.}

PAge.

Acetylene Bullding Exhibits . . . . . 133

Agrieultural Implements. . . . . . 143

Agricnitural Exhibits . . . . 200

Bazarar lsuilding Exhibits . . . . . 206

Dairy Exhibits . . . . . 204

Electricity Exbibits $\ldots . . \cdots 146$

Ethnology Exhibits . . . . . 177

Floricultural Exhibits . : . : 195

Foods and Accessories. . . . . . . . 126

Forestry Exhibits ... . . 198

Graphic Arts Exhibits . . . . . 172

Horticultural Exhibits
PAGE.

Liberal Arts . . . . . . . . . 110

Live Stock Pavilion ... . 205

Machinery and Trunsportation Exinibits 134

Mannfactures Exhibits . $\quad . . .99$

Manufactures Pergola Exhibits : : . 132

Mines Exhibits ........... 151

Mission Building . . . . . . . . . 133

Model Dairy

Orduance Exhibits . . . . . . . . 175

Railway Exbibits . . . . . 144

U. S. Government Exhibits. . $\because 203$ 

